$$
\begin{gathered}
\text { UNIVERSIDADE DE SÃO PAULO } \\
\text { FACULDADE DE FILOSOFIA, LETRAS E CIÊNCIAS HUMANAS } \\
\text { DEPARTAMENTO DE HISTÓRIA } \\
\text { PROGRAMA DE PÓS-GRADUAÇÃO EM HISTÓRIA SOCIAL }
\end{gathered}
$$

\title{
Entre Roma e Capri: o afastamento de Tibério César como ponto de inflexão política durante seu Principado (14-37 d.C.)
}

VERSÃO CORRIGIDA

Rafael da Costa Campos

Tese apresentada ao Programa de Pós-Graduação em História Social do Departamento de História da Faculdade de Filosofia, Letras e Ciências Humanas da Universidade de São Paulo, para a obtenção do título de Doutor em História.

Orientador: Prof. Dr. Norberto Luiz Guarinello 
Entre Roma e Capri: o afastamento de Tibério César como ponto de inflexão política durante seu Principado (14-37 d.C.)

Tese apresentada ao Programa de Pós-Graduação em História Social do Departamento de História da Faculdade de Filosofia, Letras e Ciências Humanas da Universidade de São Paulo, para a obtenção do título de Doutor em História.

Orientador: Prof. Dr. Norberto Luiz Guarinello 
Autorizo a reprodução e divulgação total e parcial deste trabalho, por qualquer tipo convencional ou eletrônico, para fins de estudo e pesquisa, desde que citada a fonte. 
CAMPOS, Rafael da Costa. Entre Roma e Capri: o afastamento de Tibério César como ponto de inflexão política durante seu Principado (14-37 d.C.). Tese apresentada ao programa de pós-graduação em História Social da Faculdade de Filosofia, Letras e Ciências Humanas da Universidade de São Paulo para obtenção do título de Doutor em História Social.

\section{APROVADO EM:}

\section{BANCA EXAMINADORA}

Prof.Dr.

Instituição: Julgamento:

Assinatura:

Prof.Dr.

Instituição: Julgamento:

Assinatura:

Prof.Dr.

Instituição: Julgamento:

Assinatura:

Prof.Dr.

Instituição: Julgamento:

Assinatura:

Prof.Dr:

Instituição: Julgamento:

Assinatura: 


\section{AGRADECIMENTOS}

Ao Prof. Dr. Norberto Luiz Guarinello pela convivência e dedicação na orientação e supervisão deste trabalho.

Aos professores doutores Ana Teresa Marques Gonçalves, Carlos Machado e Fábio Faversani, pelas importantes críticas, considerações e amigáveis conselhos.

À Faculdade de Letras, Filosofia e Ciências Humanas da Universidade de São Paulo, pela estrutura institucional oferecida para a elaboração desta tese.

Ao professor doutor Bryan Ward-Perkins por ter possibilitado minha visita de estudos à Universidade de Oxford para a conclusão desta tese.

Aos meus pais, familiares, Lia Ceron, amigos, e aos colegas de pesquisa e de trabalho pelo apoio e paciência durante todos estes anos de pesquisa. 


\begin{abstract}
Aunque ni el diablo sabe qué es lo que ha de recordar la gente, ni por qué. En realidad, siempre he pensado que no hay memoria coletiva, lo que quizá sea una forma de defensa de la especie humana. La frase "todo tiempo pasado fue mejor" no indica que antes sucedieran menos cosas malas, sino que - felizmente - la gente las echa en el olvido.
\end{abstract}

Ernesto Sabato, El túnel. 


\section{RESUMO}

CAMPOS, Rafael da Costa. Entre Roma e Capri: o afastamento de Tibério César como ponto de inflexão política durante seu Principado (14-37 d.C.)

O objetivo desta tese é defender que o afastamento do Imperador Tibério César Augusto em 26 d.C. representou um importante momento de inflexão política em seu governo (14 - 37 d.C.). Augusto, seu antecessor, Ihe deixou como legado um novo sistema político que, embora tenha agregado precedentes republicanos, constituiu-se como um conjunto de experimentações processuais sem uma consolidação definitiva. Tibério deu continuidade a este sistema, uma delicada relação de manutenção do prestígio aristocrático, os precedentes de seu antecessor e a ascensão da corte imperial, novo cerne do poder em Roma. Todavia, uma vez que a autonomia e participação do Senado já não possuíam a mesma efervescência republicana, a definição dos limites de atuação e influência entre o Imperador e a instituição senatorial tornou-se cada vez mais complexa e conflituosa. A esta condição somou-se o ambiente de intrigas e disputas sucessórias entre os núcleos familiares Júlio-Claudianos, cuja rede de interesses ampliou-se com a participação de indivíduos oriundos da aristocracia, principalmente pelo desmantelamento do esquema sucessório concebido por Augusto com as sucessivas mortes dos jovens príncipes candidatos ao poder. Esta conjuntura de tensão politica agravou-se com a ascensão de Sejano, prefeito da guarda pretoriana, que exerceu uma influência inédita sobre os desígnios de Tibério e contribuiu para que este finalmente se retirasse de Roma. A ilha de Capri, na costa da Campânia, além de um retiro aprazível das preocupações políticas da capital, tornou-se também o novo cerne do poder decisório, percepção surpreendente e acrimoniosa para a opinião pública deste período. O Império continuou a ser administrado sem a presença cotidiana do Princeps em Roma, não obstante seu deslocamento tenha se constituído como um filtro que passou a condicionar a dinâmica das interações entre Tibério, a corte e o restante da aristocracia. Igualmente, a ausência do Imperador deu margem à exploração indiscriminada das condenações por traição à majestade (maiestas), um novo elemento ao tradicional contexto de competividade que marcou a história do Senado, o acirramento de disputas entre membros da família imperial em Roma e a interferência desmesurada de Sejano nos rumos da sucessão dinástica, em que inúmeros membros da aristocracia foram posicionados variadamente no interior deste conflito. A eliminação de Sejano não atenuou esta situação, e seu sucessor Névio Sutório Macro continuou a influenciar senadores e equestres, que nos últimos anos de vida de Tibério se viram divididos entre o receio de continuar ou não apoiando um Imperador distante - conquanto ciente de suas prerrogativas de comando - ou um potencial sucessor, Calígula. 
Palavras-chave: Império Romano; Principado; Tibério César.

\section{ABSTRACT}

The main purpose of this thesis is to assert that the departure of Tiberius Caesar Augustus in $26 \mathrm{AD}$ characterized an important moment of political inflexion in his government (14 - $37 \mathrm{AD})$. As a legacy, his antecessor Augustus left him a new political system that had constituted as a set of processual experimentations without a definitive consolidation, although had he aggregated republican precedents. Tiberius had to give continuity to this system through a delicated relationship of maintenance of the aristocratic dignity, his antecessor's precedents and the accession of the imperial court, the new source of political power in Rome. However, once the autonomy and Senate's participation do not longer have the same republican effervescence, the definition of the boundaries of procedure and influence between the Emperor and the senatorial body became more and more complex and conflictuous. To this, it has added the ambience of gossip and sucessory struggles between the Julian-Claudian households, whose network of interests has expanded of the participation of individuals arising from aristocracy, mostly by the dismantlement of the sucessory scheme previously conceived by Augustus due to the successive deaths of the young princes as potential candidates to the supreme power. This conjuncture of political tension has aggravated with Sejanus accession, prefect of the Praetorian Guard, who has exercised an unparalleled influence over Tiberius' designs and had finally contributed to his departure of Rome. The island of Capri on the Campanian shore, besides being an agreeable retreat from the political concerns of the Capital, also became the new core of decisory power, a surprising and acrimonious perception to the public opinion of this period. The empire continued to be administrated without the daily presence of the Princeps in Rome, despite his departure has constituted as a filter that started to conditionate the dynamic of interactions between Tiberius, the imperial court and the rest of the aristocracy. Likewise, the emperor's absence gave rise to an indiscriminate exploitation of prosecutions for majesty treason (maiestas), a new element to the traditional context of competitiveness that has marked the Senate's history, the worsening of the familiar struggles in roman imperial family and the immoderated interference of Sejanus on the path of dynastic succession, in which several aristocracy members were variously positionated whitin this conflict. Sejanus' removal does not appeased this mood and his successor Naevius Sutorius Macro continued to influence senators and eques, that in the last years of Tiberius' life found themselves divided between the fear to keep supporting or not a distant emperor - although he was aware of his command prerrogatives - or to support a potential successor, Caligula.

Keywords: Roman Empire; Principate; Tiberius Caesar. 


\section{LISTA DE ABREVIATURAS E SIGLAS}

EJ - EHRENBERG, Victor; JONES, A.H.M. Documents illustrating the reigns of Augustus \& Tiberius. Oxford: Clarendon Press, 1949.

ILS - Inscriptiones Latinae Selectae

RG - Res Gestae Divi Augusti

SCPP - Senatus Consultum de Pisone Patre

RIC - Roman Imperial Coinage

TH - Tabula Hebana

TS - Tabula Siarensis 
Sumário

Introdução

Capítulo I - O Principado de Augusto: aspectos gerais -------------------26

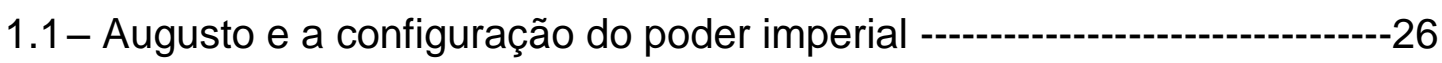

1.2- Os mecanismos de legitimação do poder de Augusto -----------------47

1.3- Augusto e a aristocracia em Roma ------------------------------59

1.3.1 - O Senado ---

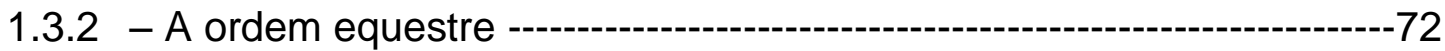

1.3.3 - A Corte Imperial ---

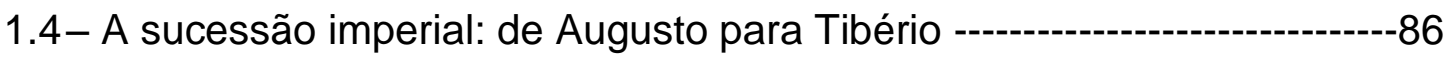

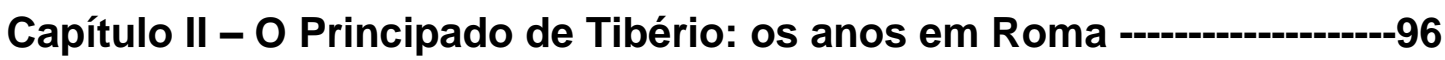

2.1 - Tibério Princeps: a família imperial no cerne do poder -----------------96

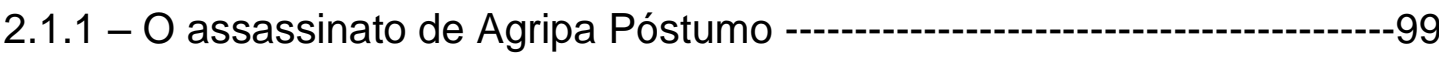

2.1.2 - Germânico César e Druso Cláudio -----109

2.2 - Tibério e o Senado (14 - 26 d.C.): Princeps senatus ---

2.3 - Tibério e o Senado: os problemas na aplicação da lei de traição (Lex lulia de Maiestatis) -------

2.4 - A ascensão de Sejano e a morte de Druso ---

Capítulo III - O Principado de Tibério: os anos em Capri ---------------202

3.1 - Por que Capri? --

3.2 - A sucessão imperial ---

3.2.1 - O afastamento do Princeps: breve êxito e eliminação de Sejano----224

3.2.2 - O caminho da transição ---

3.3 - Entre Roma e Capri: governando o Império -------------------------265

Conclusão --1- 284

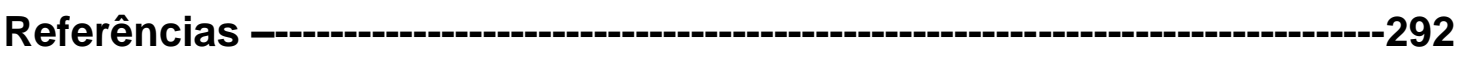

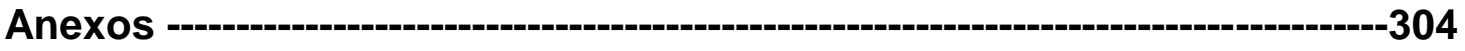




\section{INTRODUÇÃO}

Tibério César Augusto, nascido Tibério Cláudio Nero (42 a.C. - 37 d.C.), oriundo da tradicional linhagem republicana dos Claudii, sucedeu Otávio Augusto como o segundo Imperador de Roma, e governou o Império entre $14 \mathrm{e}$ 37 d.C. Filho de Tibério Cláudio Nero, casado com Lívia Drusilla (que em 39 a.C. divorciou-se do primeiro para se casar com o futuro Augusto, fazendo do jovem Tibério um enteado), o futuro sucessor de Augusto foi desde cedo introduzido ao poder. Tendo desempenhado importantes funções públicas e militares desde a maturidade, o destino de Tibério transformou-se de fato em 11 a.C., após a morte do general equestre Marco Agripa, principal braço-direito deste Imperador, fato que levou Augusto a conceder Tibério a mão de Júlia Augusta, sua única filha de sangue. Embora o casamento tenha sido conturbado e Tibério preterido no esquema sucessório, a trágica morte de Gaio e Lúcio César (filhos de Agripa e Júlia e potenciais herdeiros de Augusto) fez com que em 4 d.C. o primeiro fosse oficialmente adotado pelo Princeps e, além de ingressar na família Júlia, tornasse-se candidato para a sucessão imperial.

Embora a tradição evidencie que Tibério foi encarregado de ser guardião da sucessão de seu sobrinho Germânico César, não somente ele, mas seu próprio filho Druso Cláudio faleceram em 19 e 23 d.C., respectivamente. Agripina Maior, viúva do primeiro e mãe de Nero e Druso, jovens príncipes e possíveis herdeiros diante da necessidade de se manter o esquema dinástico concebido por Augusto, pereceram anos mais tarde em uma disputa dinástica que contou com a interferência do equestre e prefeito da guarda pretoriana Lúcio Aélio Sejano, desejoso de vincular-se à família imperial por casamento com Lívia Júlia, viúva de Druso Cláudio. Com a morte de todos estes entre 31 e 33 d.C., a Tibério restou promover o jovem Gaio César (Calígula), filho caçula de Agripina e Germânico, que pouco após assumir o Principado, eliminou o pequeno Tibério Gemelo, filho de Druso, neto consanguíneo do falecido Princeps e, portanto, outro candidato à sucessão imperial.

Além de ter representado a junção de duas importantes linhagens republicanas no seio da família imperial, o seu Principado, e todo o período que abarcou a dinastia dos Césares Júlio-Claudianos (27 a.C. até 69 d.C.), pode ser considerado como um importante momento de experimentação política: 
cada Princeps desta dinastia lidou com a necessidade de retomar ideais políticos e os elementos institucionais do período republicano.

Tibério herdou de seu antecessor um posto político constituído mediante uma sucessão de etapas que objetivaram a legitimação de Augusto como soberano. Contudo, a despeito das constantes ligações estabelecidas com o período anterior visando o estabelecimento de um consenso quanto à sua soberania, esta posição não se cristalizou, e tampouco trouxe para seu sucessor algo pronto e acabado. Tibério também lidou com a necessidade de definir parâmetros de governabilidade diante da ausência de precedentes mais concretos. A única referência, para além da herança de Augusto, constituiu-se das iniciativas em larga medida decorrentes do carisma e prestígio conquistados pelo falecido Princeps. Este conjunto de fatores foi ponderado por Tibério desde o início, mas a maneira com a qual ele lidou com a responsabilidade não foi uma mera repetição da atuação de Augusto; como Calígula, Cláudio e Nero, Tibério também teve que sustentar os vínculos e manter interações com seus interlocutores políticos dentro da aristocracia.

Neste contexto, observarmos que o Principado de Tibério foi marcado por um importante fenômeno: o afastamento do Princeps da cidade de Roma para a ilha de Capri, situada no litoral da Campânia, na costa oeste italiana, em meados de 26 d.C. Isoladamente, esta iniciativa não destoou de um antigo hábito comum entre os membros da aristocracia romana, ou mesmo de Augusto e do próprio Tibério: passar várias temporadas em suas propriedades espalhadas pela região, uma pausa para o lazer em meio às atribulações cotidianas dos negócios públicos. Todavia, ao contrário da maior parte de seus concidadãos, este Princeps, embora repeditamente anunciasse que voltaria a qualquer momento para Roma, por fim não mais retornou para a capital do Império. Nesta peculiaridade reside o foco de nossa tese.

A nosso ver, o afastamento de Tibério para Capri constituiu-se como um marco de inflexão política durante o seu Principado, e o ato de governar longe de Roma, constituindo fora dessa cidade uma nova corte imperial, um experimento emblemático para a história do sistema político que suplantou a República. Ao se deslocar do tradicional centro geopolítico de poder na península itálica para a costa da Campânia, o afastamento de Tibério ressaltou a importância das redes de interação social e política entre a aristocracia 
senatorial e equestre da cidade de Roma e o Princeps. Mais ainda, fora de Roma, Tibério estabeleceu uma espécie de filtro na dinâmica de acesso dos primeiros à corte em Capri e à sua própria pessoa, condição que comprometeu a reciprocidade de suas relações com a maior parte desses indivíduos.

O deslocamento do Princeps não deve ser entendido como mero capricho de sua personalidade; quando Tibério se afasta da Cidade de Roma e da península itálica, estabelecendo o mar como uma barreira - conquanto Tibério pudesse observar aqueles que se movimentavam na costa -, esta não representou apenas um obstáculo natural: se tratou de um obstáculo político, um componente regulador do acesso à pessoa do Imperador, um deslocamento do centro decisório do poder; as motivações e desdobramentos desse fenômeno, inseridos dentro de um contexto mais amplo sobre a história do Principado, nos ajudam a compreender como o governo dos Césares JúlioClaudianos caracterizou-se como um período de profunda experimentação política, em que cada novo Imperador precisou reformular suas estratégias de comando para assegurar a legitimidade de sua soberania perante os grupos sociais relacionados ao poder imperial.

Nesse sentido, o afastamento de Tibério mostrou-se como um experimento político dentro de seu próprio governo e seus efeitos no conjunto das relações com a família, corte imperial e aristocracia senatorial e equestre da cidade de Roma pesaram decisivamente para sua posteridade. Sob esta condição, analisaremos dois dos principais espaços políticos do Principado: a corte imperial, um novo elemento que surge com a ascensão de Augusto, e o Senado romano, instituição que buscou perpetuar em suas estruturas a tradição e a glória do passado republicano. Durante suas décadas iniciais, especialmente durante o governo dos Césares Júlio-Claudianos, a reconfiguração das tradicionais instituições republicanas fundiu-se à existência de redes de solidariedade e disputa protagonizada por indivíduos, casas aristocráticas (tanto aquelas que mantiveram sua presença e prestígio de outrora quanto novas famílias ascendentes a partir da crise da República), e indivíduos específicos inseridos na corte imperial. Esta rede tinha como cerne a figura do Imperador, sendo extremamente difícil delimitar as fronteiras entre 0 público e o privado, condição inerente à própria organização política da sociedade romana. 
Se não conseguimos diferenciar por completo a presença e ação do Imperador do funcionamento das instituições republicanas que se reconfiguraram gradual e experimentalmente a partir de Augusto com seus concidadãos, o afastamento de Tibério para Capri insere-se dentro deste complexo debate. Na distância, suas idiossincrasias tomaram rumos cujo controle já haviam se mostrado previamente conflituosos durante o comando de Augusto: as disputas por influência e preferência no esquema da sucessão dinástica de um lado, a ambição e a busca por favorecimento e promoção política e social de outro. Tibério já conhecia bastante bem esta conjuntura antes de ascender ao poder; ao se retirar para Capri - talvez enquanto alternativa para distanciar-se das tensões que o circundavam, estas se agravaram.

Nesse ínterim, a particular influência do prefeito da guarda pretoriana foi muito importante para compreendermos os efeitos do afastamento de Tibério para o cenário político de Roma. Com o passar dos anos, o Princeps se viu cada vez mais isolado de interlocutores e conselheiros para a administração do Império. Evidenciaremos que, enquanto um verdadeiro assessor e colega do Imperador, Lúcio Aélio Sejano tornou-se braço-direito e intermediário do soberano nas responsabilidades do governo. Sejano tornou-se o principal porta-voz do Imperador em Roma, deliberando sobre as questões cotidianas da administração e a atuação de seus pares mediante correspondências. Entretanto, a gradual concessão de confiança e promoção política fez com que Sejano se tornasse uma interferência perniciosa para a autoridade de Tibério.

Assim, Sejano tornou-se outro referencial de acesso e favorecimento na medida em que passou a competir, em termos práticos, com a soberania do Princeps. O primeiro interferiu no processo de sucessão imperial e nas ambições de senadores e equestres, especialmente com a intensificação das acusações pela lei de traição à majestade imperial. Somados ao distanciamento do soberano, em um regime político em que a presença (ou a representação) do Imperador sustentará em larga medida a continuidade e o consenso sobre o seu próprio poder, estes fatores por fim definiram os anos finais de Tibério e sua sucessão.

Após a eliminação de Sejano em 31 d.C., Névio Sutório Macro assumiu o posto de prefeito da guarda pretoriana e continuou a utilizar a influência que 
este cargo possuía para construir as relações de acesso ao futuro Imperador, Calígula, embora sem o mesmo ímpeto de seu antecessor. Em contrapartida, a morte de Sejano não alterou a animosidade entre os membros da aristocracia e tampouco fez com o Princeps retornasse em definitivo para Roma. Em verdade, durante os anos finais do governo de Tibério percebe-se que 0 infortúnio quanto ao destino de inúmeros aristocratas perseguidos, a eliminação de membros da família imperial populares perante a plebe, bem como a antipatia desta última por Tibério, acrescidos de um imaginário de perversidade alimentado pela sua consciente reclusão contribuíram para sua má-posteridade e de seu governo.

Esta condição mostra-se bem evidente em uma passagem do obituário de Tibério fornecido por Tácito ${ }^{1}$ :

No que diz respeito ao seu comportamento também houve diferentes fases: uma excepcional em relação à vida e reputação enquanto foi um indivíduo privado ou sob o comando de Augusto; uma pérfida e dissimulada na fabricação de virtudes enquanto Germânico e Druso eram vivos; ele foi simultaneamente uma mistura de bem e mal durante a vida de sua mãe; infame por sua selvageria, mas com suas concupiscências encobertas, na medida em que ele sentia respeito ou temor por Sejano; finalmente ele irrompeu de forma idêntica em crimes e degradações quando por fim, com sua vergonha e medo removidos, ele pôde confiar em si mesmo.

A tradição literária sobre o governo dos Césares Júlio-Claudianos foi bastante reticente a estes governantes. No que diz respeito a Tibério, com a exceção de Veléio Patérculo e, pontualmente, Valério Máximo, os testemunhos de Tácito, Suetônio e Dion Cássio, posteriores ao seu período, foram influenciados por outras narrativas que praticamente desconhecemos, além de apresentarem variadas nuances estilísticas que corroboram uma tradição arraigada aos valores aristocracia senatorial, em larga medida responsável por

\footnotetext{
${ }^{1}$ Anais, 6.51.3.
} 
moldar o veredito sobre o passado e a expectativa quanto à recepção de seus interlocutores.

Esta afirmação não apresenta nenhuma novidade: estudos sobre a concepção e narrativa histórica no mundo romano são abundantes e passam por constantes renovações. Para nosso intento, afirmamos que a narrativa historiográfica sobre o período imperial apresenta o interesse de buscar justificativas para explicar o que Roma havia se tornado para seus contemporâneos. Além do prazer literário, era necessário exaltar, inspirar, buscar referenciais morais que legitimassem a magnitude do Império e seu povo, fosse para dizer o que melhorou, ou o que piorou com o tempo, em relação aos romanos ou os seus governados:

Para os antigos, escrever história certamente era compor em um gênero literário; e assim como a poesia ou a oratória, havia propriedades gerais a serem respeitadas. A História narrativa e a sua narração necessitavam estar habilmente construídas para proporcionar prazer literário [...]. Os historiadores da Roma imperial escreveram não apenas para descrever, mas para justificar o que Roma havia se tornado no presente momento - uma potência mundial que havia eclipsado todos os rivais mediterrânicos - e ao fazer isto eles implicitamente endossaram a estrutura política e social que mantivera seu poder. [...] Em suma, o programa da historiografia romana era coberto por uma ideologia patriótica; era escrito para exortar e inspirar, e o cerne desta empreitada a articulação e reafirmação de uma identidade cultural e nacional idealizada ${ }^{2}$.

Estamos cientes da necessidade de considerarmos a intencionalidade dos autores. Contudo, ao longo deste trabalho optamos por não nos aferrarmos às personalidades dos indivíduos para determinar as causalidades e desdobramentos do governo de Tibério, não obstante a literatura utilizada possua um potencial sedutor para tanto. Este Princeps foi caracterizado como um mau governante ou um tirano pela maneira como os escritores lidaram com a demonização de sua memória pelos contemporâneos, e pela credulidade dos

\footnotetext{
${ }^{2}$ SMITH, 2006, p. 414.
} 
primeiros pesquisadores sobre o Principado com relação aos testemunhos presentes nas fontes. A personalidade de Tibéiro é representada como bastante diferente da de Júlio César ou de Augusto; aparentemente mais introspectivo ou reservado que estes dois primeiros, seu posicionamento foi associado à dita arrogância de sua linhagem, ou à inerente crueldade e devassidão, deduzidas de seu posicionamento perante o trágico fim de vários membros da família imperial, ou de seus momentos de reclusão, como fora no seu primeiro exílio em Rodes (antes de se tornar Imperador), e posteriormente em Capri.

Por ser diferente de Augusto, mas mais provavelmente por não se valer dos mesmos estratagemas políticos de seu antecessor, Tibério também não conseguiu cativar a empatia da plebe urbana de Roma. Embora nossas evidências silenciem a voz da população comum e descreva sua postura perante o Imperador de acordo com os preconceitos das camadas superiores, este fato fortaleceu o conjunto de argumentos que por fim endossou a máposteridade de seu governo. Por outro lado, estando em Roma ou em Capri, Tibério manteve em linhas gerais a condução da administração imperial em moldes semelhantes aos de Augusto, sem grandes inovações, mas também sem maiores sobressaltos - a crise financeira de 33 d.C. talvez tenha sido a maior intempérie com a qual este Princeps tivera de lidar.

A proposição deste tema de pesquisa insere-se no conjunto das mais recentes contribuições da historiografia sobre o Principado Romano. O governo de Tibério representa uma etapa no processo de transformação da organização política da sociedade romana, cujas características foram consideradas ao longo do século passado em duas perspectivas que sintetizam em linhas bastante gerais as principais contribuições sobre o estabelecimento deste sistema. Nesse sentido, as contribuições de Theodor Mommsen (1892), M. Rostovtzeff (1957) e Ronald Syme (1939) são basilares. O primeiro preocupouse em compreender as bases constitucionalistas do Principado, responsáveis por assegurar a existência de uma monarquia amparada por elementos legais republicanos, em última instância corroborada pela cooperação (Diarquia) entre Imperador e Senado. O segundo focaliza a iniciativa centralizadora de Augusto sustentada principalmente pela influência das finanças e do exército romanos: a satisfação da plebe, o controle da aristocracia, a concentração das 
prerrogativas institucionais, que por fim permitiram-no legitimar sua autoridade e promover reformas sociais e morais. O terceiro aponta que estas transformações não foram promovidas sem o apoio de aristocracia que ascendeu em meio às convulsões civis do final da República, e que como Augusto, originou-se entre os homens novos italianos e de demais províncias do Império, cujo apoio foi fundamental para o estabelecimento do Principado.

Sem desconsiderar estas premissas, a segunda perspectiva - com contribuições mais recentes - abarca a importância das relações de poder entre o soberano e os indivíduos próximos da esfera de poder. Jean Béranger (1953) demonstra que as bases constitucionais republicanas são secundárias perante a iniciativa individual de Augusto, cuja glorificação de seus méritos pelo restabelecimento da paz civil tornou-se o mote pelo qual o Princeps estabeleceu de fato uma relação monárquica com seus governados, inspirada principalmente nos reis helenísticos. Contudo, análises contemporâneas demonstram que poder e direito não podem ser categorias excludentes quando se busca uma explicação para a natureza do Principado. Winterling (2010) recentemente apontou a seguinte ambivalência: o fracasso dos Imperadores que desconsideraram as instituições republicanas demonstra que os aspectos constitucionais foram relevantes para a soberania, na mesma medida em que a legalização da posição do Imperador não foi possível sem uma real posição de poder daqueles que reivindicaram para si o comando.

Deste modo e em retrospectiva, embora o Imperador continue sendo figura central para se pensar as causas que permitiram a longa duração do Império, e posicionamentos como os de Mommsen e Béranger tenham simultaneamente sido endossados ou revisados durante o último século, o Principado não pode ser pensado como o resultado das iniciativas pessoais dos Imperadores perante grupos sociais passivos, mas sim como a confluência de interações, influências e redes de poder e solidariedade visando interesses variavelmente mútuos ou específicos.

Considerando-se então contribuições como as de Ramsay MacMullen (1974), Fergus Millar (1977 [2001]) Geoffrey de Ste. Croix (1989) e Richard Saller (1982), compreendemos que a manutenção deste sistema política não se deu sem a existência de uma interlocução entre soberanos e governados. Para o primeiro, o apoio do Princeps e da família imperial na obtenção de 
cargos e benefícios condicionou a permanência de indivíduos dentro da aristocracia senatorial, sem desconsiderar os tradicionais requisitos republicanos de fortuna, linhagem e status. O segundo aponta que a vinculação social e hierárquica dos governados relacionou-se diretamente com a engrenagem administrativa imperial que permitiu a difusão e consolidação do poder imperial. O terceiro conclui que o Imperador não poderia simplesmente ignorar ou suprimir os descontentes pelo uso da força, mas sim obter a adesão dos cidadãos imperiais como maneira de manter sua legitimidade. E o quarto pontua que em meio às divisões e tensões derivadas da desigualdade social no mundo romano foram contrabalanceadas por forças de coesão (patronagem) oriundas da corte imperial, e desdobradas horizontal e verticalmente entre indivíduos, famílias e demais clientes, um amálgama para o aparato simbólico e coercitivo do Estado.

Por fim, nos últimos trinta anos, a influência das discussões presentes em uma historiografia cada vez mais preocupada com a análise dos aspectos culturais na sociedade se fez notar também no âmbito das pesquisas sobre o mundo romano. Arnaldo Momigliano (1968 [2004]) já havia atentado para esta tomada de direção na década de sessenta do século passado; as instituições, leis, crenças e costumes deviam ser vistas como um todo, pois estavam presentes na história de toda nação ou estado, de maneira inter-relacionada, e a história não podia mais ser simplesmente confinada aos acontecimentos políticos. O crescente interesse no diálogo com as demais ciências sociais, sobretudo pelos postulados que advieram do funcionalismo, estruturalismo e pós-estruturalismo, influenciaram pesquisadores na Europa e Estados Unidos. Paul Zanker (1988) aponta que, além do uso da força e da patronagem, a difusão de imagens e representações que reforçavam a soberania de Augusto e da família imperial, e que se constituíram como um conjunto simbólico de valores morais e virtudes cívicas foi um fator extremamente importante para a manutenção da legitimidade do Princeps.

Com Andrew Wallace-Hadrill (1997), observa-se que as mudanças de ordem política entre a República e o Principado vieram acompanhadas de outras de cunho ideológico e moral, atuando reciprocamente nos meios de comunicação e conhecimento. Richard Miles (2000) aponta que esta condição pressupõe interações entre o Imperador e seus governados a partir de um 
controle do primeiro sobre os meios de comunicação oficiais. Para Clifford Ando (2000), a obediência dos grupos sociais, especialmente nas províncias, foi sustentada também pela disseminação de um complexo sistema de crenças que sancionavam a ideia de uma ordem em toda a extensão do império. Diante deste quadro, para J. E. Lendon (2004) o poder do Imperador constituiu-se e manteve pela criação de uma rede de relações de honra, envolvendo o Princeps e seus governados: mais do que clientes, estes últimos tornam-se dignitários do primeiro.

Estas reflexões também encontraram ressonância no Brasil. Para Ana Teresa Gonçalves (1999), a construção de uma imagem imperial liga-se diretamente ao contexto, aos padrões e valores presentes e compartilhados no mundo romano, e complementou-se à força armada, à munificência e à formação de alianças políticas oriundas do Imperador: cada Princeps tentou ao seu modo e interesse difundir a imagem de que possuíam virtudes morais, militares e administrativas esperadas de um soberano. Norberto Guarinello e Fábio Duarte Joly (2001) apontam que o Principado foi, a despeito da supremacia do Imperador, um espaço público efetivo em que foram apresentadas demandas políticas concretas, individuais e coletivas, um complexo jogo entre diversos grupos sociais com diferentes escalas e maneiras de participação.

Através destes pressupostos direcionaremos nossos esforços para uma análise do governo de Tibério, não obstante outras referências apareçam durante o restante de nosso trabalho. Mais especificamente, a biografia sobre este Imperador já recebera diversos exames. Dentre vários pesquisadores que já se dedicaram ao tema, citamos Frank Burr Marsh, cuja contribuição foi a mais significativa e influente para os autores que posteriormente escreveram sobre este Imperador: Marsh buscou reconstruir a história do governo de Tibério a partir de suas fontes (evidentemente sendo de Tácito o mais extenso e detalhado relato), todavia buscando a separação entre o que é possível abstrair das circunstancias que caracterizaram seu governo, e não apenas mediante a composição feita por Tácito ou no preconceito reverberado da tradição presente nos demais historiadores do século II d.C (MARSH, 1931, p. 14-5). 
Robin Seager (1971 [2004]) foi o primeiro pesquisador a escrever outra biografia após o estudo preliminar feito por Frank Burr Marsh ${ }^{3}$. Para Seager, o governo de Tibério foi simultaneamente um período de transição e consolidação. A despeito de seu respeito pelas tradições da aristocracia republicana, os efeitos de certos traços de sua personalidade combinaram-se à natureza centralizadora do Principado, provocaram o enfraquecimento, a desmoralização deste segmento social, e por fim prepararam o caminho para Calígula e Cláudio. Nesse sentido, embora Tibério tenha feito repetidos esforços para estimular o Senado a ser mais participativo, Augusto já havia minado a capacidade desta instituição de agir com autonomia; o golpe final nesta iniciativa teria sido seu afastamento para Capri. Ademais, o Principado de Tibério não teria provocado alterações significativas no cotidiano dos demais grupos sociais.

Anos mais tarde, Barbara Levick (1976 [1999]) também escreveu uma biografia sobre este Imperador. Fortemente influenciada por Ronald Syme, se inspirou nas contendas por poder, posição e prestígio que motivaram os políticos romanos desde o período republicano e que são intrínsecas à composição deste Estado. Por outro lado, Levick também se preocupou com as linhas constitucionais que vincularam República e Principado; e como no período anterior, os romanos continuaram a se valer da patronagem, amizade e das alianças para alcançar postos políticos e manter a proeminência, tudo isso diante do problema que consistiu da dicotomia entre o espaço de um senador no Principado, e o de um Princeps na República. De modo semelhante à Seager, Levick acredita que Tibério falhou em sua tentativa de conciliar a estrutura de poder engendrada por Augusto com a sua concepção pessoal de supremacia da aristocracia senatorial. Na medida em que suas relações com seus familiares e o Senado foram tornando-se cada vez mais difíceis, o Princeps optou pelo distanciamento. No que se referiu ao restante da população imperial, Tibério foi pragmático: consciente de suas obrigações, ele agiu como um nobre em relação aos seus clientes, com as devidas proporções de seu posto político.

\footnotetext{
${ }^{3}$ Nesse ínterim, ressaltamos também a importante contribuição de D.M. Pippidi, Autour de Tibère (1944), embora não seja uma biografia, e sim um estudo de temas pertinentes ao governo de Tibério e sobre as fontes que o narraram. Cf. referências.
} 
David Shotter também escreveu uma breve biografia de Tibério em 1992. Este pesquisador definiu o Principado deste último como um enigma para seus contemporâneos. O Princeps teria expressado relutância no exercício de suas responsabilidades e das oportunidades singulares que seu antecessor havia constituído. Embora ciente da importância de Augusto para sua própria ascensão, as diferenças em relação ao passado republicano eram muito evidentes para serem desconsideradas, e a despeito de sua prática não ter sido um retorno à República, o conflito entre suas próprias concepções de comando e as armadilhas cotidianas da política culminaram em frustração e introspecção ao final de sua vida. Em 1999, Zvi Yavetz publicou outro estudo temático sobre Tibério, que a nosso ver dialoga traz grande similaridade com Pippidi (1944), com especial ênfase em uma nova aproximação entre a leitura de Tácito e a interpretação do Principado mediante a ótica deste autor.

Outro importante e recente estudo foi o de Greg Rowe (2002). Tendo utilizado um conjunto de inscrições descobertas nas últimas décadas do século passado, e que em parte se complementam ao cânone literário das narrativas sobre Tibério, este pesquisador aponta para o desenvolvimento de uma cultura política imperial que demonstra como o Princeps e sua família foram inseridos em meio às instituições republicanas como referenciais de consenso e de estabilidade para o futuro deste regime; ao relacionarem-se com os potenciais sucessores de Tibério, indivíduos ou comunidades inteiras vinculavam-se em relações de honra ao Imperador.

Com relação ao período em que Tibério residiu em Capri, sobre a ilha, quem fora sua comitiva e o que fizera lá, as biografias sobre este Imperador apoiaram-se sobre as próprias evidências documentais e contribuições pontuais da historiografia, mas sem dedicarem um tópico específico para esse assunto. O arqueólogo italiano Amedeo Maiuri (1955) realizou importantes estudos durante sua vida na região da Campânia, tendo entre eles elaborado um breve itinerário com a história da ilha de Capri e a catalogação de suas ruínas, exercício pioneiro e ainda hoje uma referência. Em 1970, John D’Arms escreveu um dos mais importantes estudos sobre este assunto, relacionando as pesquisas arqueológicas anteriores com uma acurada análise de história social sobre os hábitos romanos e a presença grega nesta porção da costa oeste italiana. George Houston (1985) elaborou um artigo sobre a estadia de 
Tibério em Capri, um apanhado de todas as contribuições anteriores, bem como uma análise das eventuais companhias que estiveram com o Imperador na corte fora de Roma, embora sem adentrar mais profundamente em uma discussão sobre suas causas e consequências. Por último, sobre a residência oficial do Princeps na ilha, a chamada Villa lovis, Clemens Krause recentemente (2004) ampliou os estudos de Maiuri sobre as escavações deste edifício, e concluiu que este foi de fato concebido e construído pelo próprio Imperador para ser sua morada fora de Roma.

Os relatos sobre o governo de Tibério são majoritariamente literários ${ }^{4}$. As principais fontes que abordam o período são os seis primeiros livros dos Anais de Tácito, a biografia sobre este Imperador composta por Suetônio em sua Vida dos doze Césares, os livros LVII e LVIII da História Romana de Dion Cássio, e a última porção do segundo livro da História Romana de Veléio Patérculo, que dentre os quatro autores mencionados, foi o único contemporâneo do próprio Imperador. Outros autores também são mencionados durante esta tese, embora nenhum deles tenha escrito uma narrativa sobre o governo de Tibério. Igualmente, nos valemos dos mesmos autores para o capítulo em que abordaremos sinteticamente o governo de Augusto, bem como de seu monumento autobiográfico Res Gestae Divi Augusti. Além disso, utilizamos trechos do Senatus Consultum de Pisone Patre, Tabula Hebana e Tabula Siarensis, inscrições mais recentes que complementam trechos específicos das narrativas, organizadas e traduzidas por diversos historiadores. Outras inscrições também são mencionadas a partir do Corpus Inscriptiorum Latinorum, Inscriptiones Latinae Selectae, compiladas e traduzidas por Victor Ehrenberg e A.H.M. Jones na obra Documents illustrating the reigns of Augustus \& Tiberius, bem como inferências à epigrafia extraídas do Roman Imperial Coinage, organizado por C.H.V. Sutherland.

Diante dessas premissas optamos por escrever sobre a representatividade histórica do afastamento de Tibério para Capri. Decidimos estabelecer este fato como cerne de nossa tese, referencial pelo qual analisaremos o governo deste Imperador, não obstante a pesquisa não pretenda ser mais uma biografia sobre este soberano. Em síntese, no decorrer

\footnotetext{
${ }^{4}$ Para nosso estudo, consideramos as traduções bilíngues.
} 
deste trabalho defenderemos o afastamento de Tibério para Capri como uma mudança decisiva em seu governo. Conquanto não observemos grandes alterações em sua conduta da administração imperial, o agravamento das tensões políticas na corte imperial e entre a aristocracia senatorial e equestre de Roma impeliram este a buscar Capri como um refúgio para suas frustrações políticas. Esta saída por fim mostrou-se um agravante dentro deste panorama, pois seu distanciamento, além de representar a ausência do principal referencial de autoridade e cerne do conjunto das interações sociais entre seus concidadãos (com indissociáveis impactos para o funcionamento da instituição senatorial), contribuiu para fomentar a interferência de Sejano tanto entre os membros da aristocracia quanto no seio da família imperial.

Com isso, provavelmente provocou-se um difícil questionamento nas mentes dos indivíduos mais diretamente relacionados com a esfera do poder: onde está o centro do poder imperial? Em Roma, Capri, ou onde está o Princeps? Propomos que a soberania concentrou-se na pessoa do Imperador: a partir de sua representação política se desenvolveu uma enorme rede de solidariedades pontilhadas nas localidades do Império Romano. Consequentemente, seu afastamento apresenta um problema histórico maior, inserido dentro de um conjunto de estudos que tem reinterpretado a história sobre a sociedade romana, e certamente foi foco dos contemporâneos que nos legaram o testemunho da camada dirigente do período em questão: o funcionamento da instituição política do Principado, e as relações sociopolíticas que asseguraram a sua permanência durante quatro séculos.

Esta tese está dividida em três capítulos. Inicialmente, abordaremos sinteticamente a historiografia que tratou do estabelecimento do sistema político do Principado a partir da ascensão de Otávio Augusto em 31 d.C.. A experimentação política processual que caracterizou seu governo foi importante para que possamos compreender como se iniciou a redefinição das instituições republicanas. Diante desta primeira etapa, o segundo capítulo apresentará as condições para a ascensão de Tibério e os primeiros anos de seu governo, enquanto este permaneceu na Cidade de Roma; analisaremos sua relação com a corte imperial, a aristocracia senatorial e equestre, as causalidades que motivaram o Princeps a afastar-se de Roma, e as futuras implicações desta atitude. O terceiro capítulo remeter-se-á ao período restante 
de seu Principado, com Tibério instalado em Capri. Nesse sentido, discutiremos as possíveis razões para a predileção do Princeps pela ilha, a interferência de Sejano no governo, e os desdobramentos em relação ao futuro da família imperial e a relação do Imperador com a aristocracia nos últimos anos. Por último, ainda no terceiro capítulo, traçaremos um panorama da administração de Tibério entre Roma e Capri. 


\section{CAPÍTULO I - O PRINCIPADO DE AUGUSTO: ASPECTOS GERAIS}

\section{1. - Augusto e a configuração do poder imperial}

A partir do governo de Otávio Augusto, os aspectos que caracterizam o Principado, suas atribuições $e$ as interações estabelecidas com seus governados são temas de amplo debate. $O$ resultado de um processo iniciado quase um século antes, como consequência da guerra social italiana, e de uma sucessão de dissensões civis, proscrições e tomadas do poder por ambiciosos senadores e generais, conduziu a sociedade romana a um novo sistema de organização política que não foi um retorno à antiga monarquia dos primeiros reis de Roma, mas também já não era mais a República lendariamente originada com a expulsão de Tarquínio.

Embora o controle da força militar tenha feito da ascensão de Otaviano (futuro Augusto) uma condição unívoca, em oposição ao espectro das décadas de guerra civil, e como forma de obliterar o passado recente dos interesses individuais de senadores como Sila, Pompeu, Júlio César (a despeito do nome e do status concedido a seu sobrinho) e Marco Antônio, inicialmente o que se configuraria como Principado teve como premissa a devolução da estabilidade e da paz por intermédio de um soberano que justificou todos os seus combates pela devolução da res publica.

Consideramos res publica não apenas como "a República", mas como o termo que melhor representou a ideia de 'comunidade' para os romanos. A essência da organização de governo republicana não residiu estritamente em aspectos constitucionais, como estamos acostumados a observar nas constituições modernas. Em linhas gerais, a República pode ser compreendida como um sistema de valores e conceitos que nem sempre equivaleram à realidade política, e o seu colapso não derivou de uma transgressão constitucional, mas foi percebido (ao menos nos principais testemunhos literários da época) como a incapacidade de seus contemporâneos em aderir a este sistema de valores, que estabelecia o bem público acima dos interesses 
individuais, uma vez que tradicionalmente a boa-vontade política esteve posicionada acima dos esforços de codificação ${ }^{5}$.

De acordo com Beard e Crawford $^{6}$, para nós historiadores é bastante difícil determinar um momento de ruptura precisa; mesmo no tocante à documentação, questionarmos-nos sobre um específico momento de transformação pode ser algo irreal, ao passo que os indícios do surgimento de práticas despóticas são inúmeros. Quase duas décadas antes de Otaviano ser proclamado "Augusto", em meio às ações de Júlio César percebemos atitudes que visaram à configuração de um poder individual e durável: o cargo de dictator, o controle das deliberações senatoriais e a eleição de seus membros, uma posição religiosa próxima da deificação e atribuições semimonárquicas, todas elas evidentemente indesejáveis para a maioria de seus pares, e que the custaram a vida.

Diante desse quadro, é crível que Augusto tenha percebido que ao evitar alguns equívocos de seu predecessor, o caminho da soberania era possível, e não obstante sua complexidade, a crise da República e o processo de estabelecimento de uma nova organização do poder foram duas etapas indissociáveis de um mesmo processo. Desta forma, a partir de 44 a.C., observamos a transição de uma 'República' para o que virá a ser uma autocracia, com a emergência de um segmento social dirigente com novas características, composta não apenas da elite italiana, mas posteriormente de todo o Mediterrâneo e, sobretudo, a construção de um consenso pelo suporte de uma nova ordem política ${ }^{7}$.

Fergus Millar ${ }^{8}$ é enfático ao defender que uma 'revolução' em diversos níveis ocorrera entre as décadas de 40 e 20 a.C., envolveu romanos e não romanos, e que evidenciou uma percepção ampliada de que todos passaram a fazer e se sentir parte de um sistema político cujo controle passou a pertencer a um único soberano e, sobretudo, conservadora, "restauradora". Nesse sentido, antes de 27 a.C., Millar também afirma ${ }^{9}$ (1999, p. 8-9) que esta transformação preliminar - mas que determinou o rumo dos anos seguintes -

\footnotetext{
${ }^{5}$ GALINSKY, 1996, p. 6-7; p. 59.

${ }^{6} 1985$, p. 85-7.

${ }^{7}$ BEARD \& CRAWFORD, 1985, p. 87.

8 1999, p. $1-9$.

${ }^{9}$ Idem, p. 8-9.
} 
pode ser sumarizada em três partes: a primeira perdurou entre o retorno de Augusto (ainda Imperator Caesar) da batalha de Náuloco em 36 e os preparativos para o Áccio, pois foram anos em que o Senado e o povo de Roma vivenciaram a coexistência da instituição republicana com um líder individual, filho do deificado Júlio César (Divus Filius). A segunda fase compreendeu a saída de Augusto para o Áccio e seu retorno para o recebimento do triplo triunfo em 29 a.C., e que durante esse período permaneceu no Oriente, fato que representou a constituição de um "Império" familiar ao mundo grego e suas comunidades (embora não tenha havido uma prévia e rígida divisão durante a República). E por último, considerou-se os anos entre 31 e 29 a.C., período de continuidade das atividades militares e diplomáticas de Augusto no Oriente, e em que a Cidade de Roma passou por uma remodelação urbanístico-religiosa, ambos os casos com o apoio de seus consortes Agripa e Mecenas.

Entretanto, embora como um líder do Senado (princeps senatus) e principalmente entre 27 e 23 a.C. Augusto tenha transcendido a soma dos poderes formais a ele concedidos por esta instituição e o povo de Roma, o próprio termo "Principado" não surgiu durante o seu período de governo: seus contemporâneos não conceituaram as experimentações políticas de quase cinco décadas com este nome, e o resultado deste processo não resultou finalmente em tal termo ${ }^{10}$. Todavia, existe uma diferença fundamental entre a República e o que se convencionaria tempos depois como o Principado: a emergência de um árbitro supremo - sem prerrogativa jurídica formal - que se tornou o líder da mais importante instituição republicana, o Senado, e o patrono religiosamente revestido de prestígio e autoridade de toda a população, cujas virtudes lhe permitiram proferir a última palavra como um Imperador ${ }^{11}$.

A preocupação de Augusto com a preservação da República foi tônica de todas as suas ações políticas, com ênfase em uma substancial renovação de seus ideais e valores que, embora tenha sido fruto de proposições de vários indivíduos, tiveram como aspecto comum o restabelecimento de antigos costumes romanos, mesmo que na prática isso tenha resultado na concentração e manutenção de seu próprio poder. Isto foi em parte

\footnotetext{
${ }^{10}$ GRUEN, 2007, p. 34-5.

${ }^{11}$ CROOK, 2008, p. $118,123$.
} 
consequência da própria flexibilidade destes ideais, e sua utilização para fins individuais não foi estranha a todo o período precedente, especialmente a palavra liberdade (libertas), cujo restabelecimento pelo compromisso com a res publica foi um lema que estive presente nas falas de seus generais ${ }^{12}$.

A transmissão deste compromisso para a posteridade compôs cada linha apresentada nos feitos políticos e militares por ele confeccionado e divulgado imediatamente após sua morte por Tibério. Em seus principais pontos, Augusto expôs que, após ter organizado um exército mediante seus recursos e sua própria iniciativa (44 a.C.), seu interesse fora o de libertar a República da tirania de uma facção (Marco Antônio, que não é em nenhum momento mencionado) ${ }^{13}$. Legitimado pelo Senado com o direito de opinião e o comando militar, a morte em combate dos cônsules do ano 43 a.C. permitiramIhe a investidura deste cargo e o apontamento como triúnviro para a organização do Estado ${ }^{14}$. O jovem César então exilara os assassinos de seu pai adotivo mediante uma vingança legitimada pelas leis, tendo sido derrotados no campo de batalha ao mover guerra contra a República ${ }^{15}$. Após o fim da guerra civil e no momento que, mediante o consenso universal, estivera no pleno controle dos assuntos públicos, a República fora transferida de seu poder para as mãos do Senado e o povo de Roma (27 a.C. $)^{16}$. Em razão dos seus préstimos o Senado denominou-o Augusto ${ }^{17}$, e a partir de então ele excedera os demais em influência, embora não possuísse mais poderes oficiais do que aqueles que eram seus colegas nas diversas magistraturas ${ }^{18}$. Finalmente, um quarto de século depois (2 a.C.) Augusto foi habilitado a encerrar seus feitos com a conferência, por parte do Senado, dos equestres o do povo, do título de 'pai da pátria' (pater patriae), escrita no pórtico de sua residência, no Senado e no Fórum ${ }^{19}$.

Embora a perpetuação de seus feitos aparente a ideia de que toda a sua caminhada no poder fora orquestrada, faz-se necessário ressalvas. Os anos finais da República e principalmente os desdobramentos de sua vitória militar

\footnotetext{
12 GALINSKY, 1996, p. 54-63.

${ }^{13}$ Res Gestae Divi Augusti, 1.1.

14 idem, 1.2-4.

15 ibidem, 2.

16 ibidem, 34.1.

17 ibidem, 34.2.

18 ibidem, 34.3.

19 ibidem, 35.1.
} 
consistiram de um processo de transformação de valores políticos que permitiram a Augusto e seus apoiadores a legitimação de sua inédita posição de poder, mas sob dois vieses bastante pragmáticos: como se moldaria este sistema e que posição seu líder ocuparia nele ${ }^{20}$. $O$ primeiro passo foi não repetir os equívocos políticos de César e Antônio: respectivamente explicitar o desejo de soberania em detrimento do Senado e contrariar os costumes (mores) ancestrais portando-se como um rei, e um rei estrangeiro. Não obstante a concentração de seus poderes, a representatividade das mais importantes instituições republicanas (o Senado, as assembleias populares, as magistraturas e os sacerdócios) e seus participantes tiveram seu prestígio e posição realçados ${ }^{21}$.

Ao adicionar o prenome imperator e simbolizando assim o memorável triunfo de sua vitória, Augusto inaugurou um posto de influência e risco equivalentes para si e para seus sucessores, uma vez que em tese o primeiro não poderia conduzir a sociedade como um proprietário, mas como 0 mandatário de uma coletividade que lhe conferiu legitimamente esta posição ${ }^{22}$. Sem precedentes, este compromisso foi instável desde seu início, pois não possuiu consigo uma regra automática de transmissão; este fator aludiu à renovação do temor da instabilidade e da anarquia militar em cada nova sucessão imperial, cuja alternativa criada pelo próprio Augusto foi - baseada no preceito aristocrático da transmissão da herança do pater familias para seu herdeiro - a transmissão de um legado para um sucessor dentro da própria família, alternativa que por princípio asseguraria a manutenção da paz e a continuidade do consenso, noção que passou a ser tão cara ao ideário imperial $^{23}$.

De todo modo, a ausência de regras constitucionais definidas para 0 poder do Princeps - uma vez que sua invenção se colidiria com a própria defesa de restabelecimento e perpetuação da República - fez com que o período dinástico Júlio-Claudiano fosse de grande experimentação política, e sua principal característica a variedade de elementos que asseguraram a continuidade deste regime. Embora a posição do Imperador não tenha sido

\footnotetext{
${ }^{20}$ ECK, 2007, p. 45.

${ }^{21}$ ADCOCK, 1989, p. 114; GRUEN, 2007, p. 35; ROWE, 2006, p. 114.

${ }^{22}$ VEYNE, 2002, p. 44.

${ }^{23}$ idem, p. 44-51.
} 
abertamente sistematizada pelo seu soberano e nem pelos seus contemporâneos, seu poder irrestrito foi na prática reconhecido pelos cidadãos do Império ${ }^{24}$.

Diante desse escopo básico, a ascensão e a primeira metade do governo de Augusto podem ser compreendidas como uma sucessiva acumulação de poderes e honras, uma fusão da autoridade formal (potestas) e influência (auctoritas) ${ }^{25}$, iniciada como o triunfo político-militar do único triúnviro remanescente encarregado da "restauração" da República. Concordamos com o posicionamento de Michael Grant $^{26}$, que trata desse experimento político a partir de uma dupla e majoritária divisão histórica: entre 49 e 28 a.C. Augusto (ainda Otaviano) governou em razão e mediante influência de seu imperium maius; a partir de 27 e até 14 a.C. o agora Princeps percebe que a manutenção da soberania apenas pelo imperium tornara-se pouco atrativa e controversa para muitos de seus pares, e daí em diante temos a difusão da auctoritas como a principal base de sua autoridade.

Por não terem sido preconcebidas em um longo projeto, a gradual soma destes poderes não legou a Tibério nenhum modelo pronto; muitos dilemas políticos do novo regime permaneceram, outros se intensificaram ou mesmo adquiriram novos contornos na medida das circunstancias envolvendo a ascensão e permanência de cada sucessor. A análise dos conceitos também merece ser observada com cautela, e inúmeros termos que se destacam com a ascensão de Augusto não são inéditos: não há uma distinção aparente entre palavras como libertas, dignitas, princeps, e auctoritas tal qual estas eram compreendidas durante o período Republicano e o início do Principado. Toda esta terminologia se adaptará lentamente, em conformidade à intenção de restabelecer as instituições republicanas colapsadas pela guerra civil, e encontraram ressonâncias diferentes em diferentes circunstâncias durante o período dos Césares Júlio-Claudianos ${ }^{27}$.

Em meio a tantas singularidades, qual teria sido o papel de Augusto? $\mathrm{O}$ de instigador, catalisador, ou canalizador de um fluxo histórico que buscava

\footnotetext{
${ }^{24}$ GALINSKY, 1996, p. 71; PEACHIN, 2006, p. 127; p. 147.

${ }^{25}$ GRANT, 1948, p. 98.

${ }^{26} 1969$, p. 408, 424.

${ }^{27}$ BÉRANGER, 1953, p. 132-3.
} 
alguma direção? ${ }^{28}$ Mason Hammond afirma ${ }^{29}$ que a percepção que possuímos de Tácito a respeito dos poucos resquícios da memória republicana em seus sobreviventes e o tom apologético do monumento aos feitos de Augusto não podem nos induzir a crer que a restauração de Augusto fora apenas uma ficção. Augusto fez o possível para exaltar as instituições republicanas e relembrar o Senado de seu papel e ressaltar a posição do Princeps como a de um interlocutor.

Todavia, embora Augusto tenha evitado o erro de subestimar o Senado como fizera César, tanto ele como seu sucessor tiveram problemas pela observação de que seus atuais membros já não se comportavam politicamente como outrora, e sem dúvida, Tácito reitera essa dicotomia ad nauseam durante os Anais. O flanco aberto pela separação das funções civis e militares acumuladas pelo primeiro Princeps tornou-se ainda mais evidente com suas qualificações religiosas. Esse mesmo flanco ampliou-se com seus sucessores; ao assumir o poder como sucessor e renovador de um regime de governo em constante transformação, as vicissitudes com as quais Tibério teve de lidar incluíram, para além das tradicionais disputas por poder e ascensão, a dependência do Senado da aprovação do Imperador no que tangeu à legislação, jurisdição e administração ${ }^{30}$.

Observemos panoramicamente o início desse processo ${ }^{31}$. À vitória na batalha do Actium em 31 a.C. seguiu-se a ocupação do Egito em 30 a.C. (Aegypto Capta), cujas mortes de Antônio e Cleópatra encerraram a guerra civil $^{32}$. O Senado tornou este território uma província pessoal de Augusto e a sua administração inicialmente encarregada a Gaio Cornélio Galo, equestre

\footnotetext{
${ }^{28}$ GALINSKY, 2007, p.1-2. A nosso ver, a resposta para esta pergunta - de caráter provocativo no prefácio desta obra - foi dada por ele mesmo anos antes (1996, p. 77): [...] it was a mix of political calculation, pragmatism, a sure sense of the true nature of power and its use, and a genuine understanding and appreciation of Roman traditions and sensibilities - perhaps due in part to Augustus' upbringing in the small Italian town of Velletri - in addition to some deeply held convictions and a resulting vision and sense of direction. [...]. Isto nos faz crer como a tarefa de continuar (ou não) estas responsabilidades dependeu da iniciativa articuladora do primeiro Princeps, fardo do qual Tibério teria tido bastante convicção, a despeito de sua controversa exposição ao Senado já no início de seu governo (Dion Cássio, 57.2.4; Tácito, Anais, 1.8 e 1.11-13).

29 1961, p. $195-7$.

${ }^{30}$ HAMMOND, 1961, p. 197.

${ }^{31}$ As principais fontes para o período de Augusto são: Res Gestae Divi Augusti; Suetônio, Vida de Augusto; Dion Cássio, História Romana, Livros LVII-LVI; Veléio Patérculo, História Romana, livro II, capítulos 89 a 128; Tácito, Anais, livro I, capítulos 1.2 a 15.

${ }^{32}$ CROOK, 2008, p.73.
} 
proeminente e importante consorte militar de Augusto. Por ser um território fértil e rico, a ocupação do Egito neutralizou a possibilidade de fortalecimento de um novo oponente político, atenuou a escassez financeira decorrente dos anos de guerra, e permitiu a Augusto recompensar a população italiana pelos excessos de tributos cobrados para fazer frente a Antônio, bem como pagar as terras prometidas aos seus veteranos. Outros dois importantes consortes já mencionados foram fundamentais: enquanto que M. Agripa, outro general oriundo da ordem equestre, Ihe auxiliou durante guerra, Gaio Mecenas também equestre - agiu como influente interlocutor entre a aristocracia senatorial e plebe em Roma, tendo reordenado a situação política ${ }^{33}$.

Em 29 a.C., Augusto recebeu do Senado a renovação de seu imperium obtido ainda como triúnviro em 36 a.C., com a extensão de seu comando militar a todas as províncias romanas, tanto sob sua tutela quanto do Senado, bem como tivera seu prestígio renovado ao receber a designação de Princeps (o primeiro, o mais proeminente) e o prenome permanente de imperator (comandante). Do mesmo modo, a ratificação senatorial dos arranjos diplomáticos no Oriente e o fechamento dos portões do deus Jano (Augurius Salutis) - marco religioso do fim de um ciclo, que durante muito tempo ficara em desuso - simbolizaram o fim da guerra e o começo da paz romana ${ }^{34}$. No mesmo ano Augusto retornou a Roma e desfilou em sua carruagem triunviral, acompanhado de seu sobrinho Gaio Marcelo e seu enteado Tibério, onde foram celebrados três dias de honras pelo triplo triunfo militar no llírico, Áccio e em Alexandria ${ }^{35}$. Além disso, dois monumentos foram dedicados no Fórum à glória de sua família: um templo à deificação de Júlio César, e a nova câmara senatorial (a Curia lulia) ${ }^{36}$. Por fim, ao distribuir gastar cerca de um bilhão de sestércios, celebrou a estabilidade e os auspícios das divindades romanas,

\footnotetext{
${ }^{33}$ CROOK, 2008, p. 74.

${ }^{34}$ SYME, 1939, p. 447.

${ }^{35}$ 35-33 a.C.; 31 a.C.; 30 a.C.

${ }^{36}$ Sumi (2005, p. 223) afirma que a criação da Cura lulia topograficamente representou o fim de uma era ao relacionar-se com o novo Fórum de Augusto; isto significou que a Cúria, símbolo arquitetônico da República, por ser o local de encontro do Senado, ficava de frente para um monumento criado por Augusto, local do qual este passou a demonstrar publicamente sua opinião a respeito dos negócios públicos. A nova topografia do Fórum e da Câmara sublinhou a uma redefinição na distribuição do poder político durante o Principado.
} 
realçando seu reconhecimento como o grande benfeitor (benefactor) de Roma ${ }^{37}$.

Estas concessões e honras pautadas no êxito da missão triunviral simbolizaram os primeiros passos da ascensão de Augusto, trazendo consigo a mensagem da reconstituição da liberdade reclamada pelos magistrados republicanos nos últimos anos de conflito, cujos desdobramentos devem ter demonstrado aos romanos o quanto as transformações nos valores, tradições e ideais deste período sujeitaram-se às ações políticas ${ }^{38}$. Em meio a uma população economicamente exaurida, antigas linhagens senatoriais proscritas e eliminadas, Augusto, com o apoio de seu exército e associados emergiram dos conflitos como vitoriosos; o Princeps não concebeu suas ações políticas individualmente, mas desde o início de sua ascensão - ainda como triúnviro teve ao lado agentes que anos mais tarde tornar-se-iam seus apoiadores no Império. E é justamente este Império que adveio como recompensa, a auspiciosa pax romana confirmada pela relação entre o primeiro e o deus Apolo (estabelecido como regulador da ordem do mundo) representou o êxito pelo domínio da força, e oportunizou a caminhada para a ascensão econômica e política de novos grupos de indivíduos provenientes da ltália e das províncias ao poder $^{39}$.

Em 28 a.C., ao dividir o consulado com Agripa, Augusto lançou um edito declarando inválidas todas as medidas emergenciais proclamadas durante a guerra civil, ação que representou uma importante inferência sobre seu plano de divulgar o restabelecimento da República. De fato, em seguida as eleições populares - ao menos das magistraturas menores - ocorreram sem maiores percalços, o que pode ter atenuado certas tensões políticas neste momento. De todo modo, o edito não cerceou substancialmente seu poder ${ }^{40}$, mas parecia ser necessário demonstrar que a Res publica era novamente um regime político mantido pelas leis, e não um estado em que a palavra de um Princeps significasse estritamente a $l \mathrm{e}^{41}{ }^{4}$.

\footnotetext{
${ }^{37}$ EDER, 2007, p. 23; SYME, 1939, p. 447.

${ }^{38}$ GRIMAL, 1992, p. 53.

39 SYME, 1939, p. 7; p. 350.

40 ECK, 2007, p. 50.

${ }^{41}$ EDER, 2007, p. 24.
} 
Politicamente, o anúncio da abolição das medidas triunvirais significou que tudo aquilo que foi prometido conjuntamente por Antônio e Augusto se cumprira, com a exceção de que somente o último sobreviveu para anunciar o fim da tarefa. Como cônsules, o Senado também concedeu autoridade para que empreendessem o censo (censoria potestas), que havia ocorrido pela última vez em 70 a.C., e a revisão do rol senatorial (lectio senatus), com a exclusão de vários remanescentes da antiga ordem republicana, e uma evidente neutralização de opositores políticos ao novo regime ${ }^{42}$. Esta prerrogativa fortaleceu Augusto: em 30 a.C., ele já havia recebido o direito de indicar homens novos ao Senado sob o pretexto da normatização das atividades senatoriais, diante da grande mortandade entre as linhagens republicanas de Roma, mesmo com certo descontentamento do patriciado. Neste contexto, apenas senadores podiam exercer o sacerdócio e administrar os auspícios: estes relacionavam os desígnios dos deuses ao bem-estar dos romanos, e a associação entre sua pessoa, a religião e o poder conquistado consequentemente demonstrou-se essencial para legitimar sua posição ${ }^{43}$.

Já em 27 a.C., tendo exercido novamente o consulado com Agripa, Augusto convocou o Senado, proferiu um discurso abdicando formalmente de seu imperium, restituiu as províncias por ele pacificadas ao comando do Senado, e anunciou o restabelecimento formal da República ${ }^{44}$. Isto não significou "restauração", posto que as atribuições recebidas nos anos anteriores como triúnviro e o encadeamento dos eventos históricos indicaram uma mudança na divisão do poder político, mesmo com a ambiguidade do termo presente nas evidências ${ }^{45}$. De modo semelhante, o restabelecimento não envolveu $\mathrm{o}$ retorno às antigas práticas constitucionais, mas certamente

\footnotetext{
${ }^{42}$ CROOK, 2008, p. 76.

${ }^{43}$ CROOK, 2008, p. 76; ECK, 2007, p. 49.

${ }^{44} \mathrm{~A}$ despeito de sua origem monárquica, durante a República o imperium permitia a um magistrado o poder de comando civil e militar em tempos de guerra e paz sob os romanos nas províncias, mediante confirmação religiosa que associava o ilustre senador aos auspícios dos deuses. Gradualmente, imperium adquiriu também uma conotação militarizada e territorial, conforme a expansão romana no Mediterrâneo e a emergência política de Júlio César e Augusto no final deste período.

${ }^{45}$ MILLAR, 1968, p. 265-6. Especialmente pelo exame da documentação provincial anterior ao ano de 27 a.C., que demonstra que as comunidades já buscavam apoio individual de Augusto antes da oficialização do restabelecimento da República.
} 
significou a retomada dos antigos valores republicanos como maneira de colocar o "Estado em ordem", um restabelecimento moral ${ }^{46}$.

Certamente, a "devolução" da República foi um dos passos mais importantes entre as experimentações políticas de Augusto, sintetizando entre seu regresso triunfal para Roma e esta resignação - uma sucessão de esforços para a recuperação de uma ordem política e manutenção de sua supremacia militar ${ }^{47}$. O Senado voltou a ser árbitro do poder, conquanto na prática este tenha permanecido com Augusto, o que nos demove de simplificar esta ação como uma usurpação velada, pois a esta instituição foi permitido como outrora, a livre decisão sobre a concessão de honras, prerrogativas e alocação de seus membros nas províncias; o respeito à formalidade e preservação dos elementos institucionais do Senado foi extremamente importante na transmissão da ideia de que a República havia voltado ao seu "devido lugar" 48.

Não acreditamos que Augusto estava disposto a abdicar de toda influência política conquistada. Por outro lado, o precedente de usurpação eternizado com as ações de César provavelmente norteu este soberano e sua rede de apoiadores a tentar algo que não maculasse a tradição; podemos imaginar que grande parte deste Senado agora contava com membros diretamente vinculados ao futuro Princeps. A ênfase no cerimonialismo tornouse um alicerce do governo de Augusto: ao entregar os fasces consulares para Agripa na frente do Senado e da plebe, o primeiro demonstrou que, por sua causa, o mundo romano distanciava-se neste momento das proscrições, exações e a guerra que caracterizaram o segundo triunvirato, mesmo tendo sido Augusto um dos fomentadores desta situação. Com isto, ele adaptou elementos da tradição para a preservação e legitimação de seu poder, utilizando-se de referenciais conhecidos para que o novo sistema de governo que estava estabelecendo não representasse um rompimento, mas o resgate do que existia de mais ilustre no passado romano ${ }^{49}$.

Estratagema planejado ou não, a contrapartida do Senado foi precisa: Augusto deteve novamente o controle das principais províncias por mais dez

\footnotetext{
${ }^{46}$ GALINSKY, 1996, p. 64-5.

${ }^{47}$ EDER, 2007, p. 23.

${ }^{48}$ idem, p. 24.

${ }^{49}$ SUMI, 2005, p. 220-21.
} 
anos, juntamente com a maior parte das legiões que nelas estavam estacionadas. Honras sem precedentes resultantes de uma situação política inédita ${ }^{50}$, e uma maneira de afastar o estigma de uma tirania, pois a condição legal dos enormes poderes sob as províncias (imperium proconsulare) mediante seus legados - agregou legitimidade sobre a força militar ${ }^{51}$, e sobre grandes extensões do Mediterrâneo: Hispânia, Gália, Cilícia, Chipre, Síria, e Egito. A exceção desta última, a responsabilidade sobre elas foi respaldada pelo argumento de que todas eram passíveis de invasão ou revoltas internas, com a promessa de que seriam restabelecidas ao Senado em ordem antes do prazo.

Tempos antes, Pompeu recebera um grande imperium para assegurar a estabilidade nas províncias: não era incomum a concessão de oportunidades que mostrassem o poderio romano mediante a dignitas (prestígio) de seus senadores. Diante da amplitude deste conceito ${ }^{52}$, Augusto fez com que seu poder de Princeps fosse transcendido na esfera militar: imperium agora representava também o comando militar supremo de um Imperator. Não por acaso, Augusto foi cuidadoso ao divulgar este poder, de modo a evitar o constrangimento da liberdade senatorial ${ }^{53}$ e não evidenciar ainda mais sua indefectível influência manifestada e sobreposta à dos demais desde 32 a.C.. A preservação da libertas ${ }^{54}$ justificou a existência da instituição republicana, e a sua administração pelos romanos de maior prestígio (dignitas), tributários da confiança e proteção (fides) do povo romano na autoridade corporativa do Senado ${ }^{55}$. Ao devolver a República e a liberdade para o Senado e o povo romano, a ascensão de Augusto trouxe consigo o fato de que esta liberdade dependia agora da existência de conformidade entre o soberano com a

\footnotetext{
${ }^{50}$ LACEY, 1974, 183-4.

${ }^{51}$ CROOK, 2008, p. 78; ECK, 2007, p. 52-3.

${ }^{52} \mathrm{~A}$ despeito de sua origem monárquica, durante a República o imperium permitia a um magistrado o poder de comando civil e militar em tempos de guerra e paz sob os romanos nas províncias, mediante confirmação religiosa que associava o ilustre senador aos auspícios dos deuses. Gradualmente, imperium adquiriu também uma conotação militarizada e territorial, conforme a expansão romana no Mediterrâneo e a emergência política de Júlio César e Augusto no final deste período.

${ }_{53}$ EHRENBERG, 1984, p. 119-21; JONES, 1959, p. 118-9; RICHARDSON, 1991, p.3-9.

${ }^{54} \mathrm{~A}$ principal manifestação desta liberdade era o direito do cidadão de apelar contra uma eventual injustiça de um magistrado (ius provocationis), mediante a ação de um tribuno da plebe revestido em seu cargo pela representação dos direitos do povo (NICOLET, 1976, p. 430; WIRSZUBSKI, 1968: 7-8).

${ }^{55}$ ADCOCK, 1989, p. 56-9; p.68.
} 
aristocracia senatorial, cuja transformação em sua composição ocorreu em consonância com a transformação conceitual de libertas ${ }^{56}$.

Outro elemento foi igualmente importante e se correlacionou a estes conceitos supracitados. A denominação "Augusto" (Augustus) enfatizou - em complemento à sua auctoritas - o aspecto sagrado de sua soberania, o conceito central que justificou o seu poder ${ }^{57}$. Processualmente, esta denominação baseou-se na legitimidade adquirida com o legado de César e sua deificação em 42 a.C., endossada pelo êxito de suas conquistas militares (principalmente a Gália). Neste sentido, a conjunção entre o fato de ter se tornado filho de um deus (Caesar divi filius), e sob o pretexto da vingança ter empreendido uma rápida carreira militar cujo êxito final e individual trouxe-lhe a congratulação de vencedor (vindex), formou o argumento que endossou sua aclamação.

Conforme foi enunciado acima no conjunto dos feitos de Augusto ${ }^{58}$, auctoritas é o termo que mais se aproxima da preponderância obtida pelo Imperador: o lapso ou perda desta traria ameaça ao seu comando pessoal, conquanto não tenha se restringido apenas ao plano formal: durante o seu governo, o conceito encontrou ressonância na cultura do período, especialmente na literatura e na arte, justamente pela elasticidade de seu significado e sua conjunção com os valores e ideais romanos ${ }^{59}$. A superioridade de Augusto foi moral, material e intelectual, caracterizando-o como um auctor, aquele que detém, endossa e inspira a liderança, tornando-se um referencial para a supremacia da coletividade, como consequência da enorme consideração a ele conferida.

Consentimento que exigia constante reafirmação, a auctoritas de Augusto afastou a alcunha de usurpador por se remeter à autoridade dos grandes senadores dentro da instituição senatorial de outrora, que justificavam

\footnotetext{
${ }^{56}$ HAMMOND, 1963, p. 93-6; p. 104-5.

57 GALINSKY, 1996, p. 12.

${ }^{58}$ Res Gestae Divi Augusti, 34.3.

${ }^{59}$ Derivado do verbo latino augere (aumentar, reforçar), auctoritas associava-se à potestas como justificativa da proeminência do Senado republicano pelo zelo e liberdade dos romanos, coibindo o abuso e a tirania que existiu sob os monarcas. Esta auctoritas senatorial continuou a ser valorizada dentro das relações entre o Imperador e seus pares. Todavia, sua extraordinária posição de prestígio adveio de seu protagonismo como aquele que resgatou os antigos valores desta instituição após anos de guerra, bem como acordos políticos dos aliados do Princeps, pois sua hegemonia era agora a condição de acesso e permanência dos primeiros.
} 
moralmente o fato de o povo ter cedido sua liberdade ao arbítrio deste corpo de magistrados ${ }^{60}$. Em outros termos, Augusto adquirira e mantivera sua auctoritas pelo brio de sua personalidade, pela concretude de seu poder, e simultaneamente esta prerrogativa legitimou sua força por the conferir investidura para comandar e para ser obedecido pelos demais ${ }^{61}$. A relação entre a designação "Augusto" e sua auctoritas oficializou o consenso (consensus) e comprometimento da sociedade romana àquele que, após anos de dissensão, melhor reagrupou os antigos e valorosos ideais republicanos, reabilitando-os cerimonialmente ${ }^{62}$.

Além de sua auctoritas, outros componentes confirmaram simbolicamente a proeminência do "mais ilustre": a coroa cívica em honra da salvação dos romanos, o escudo com a atribuição das maiores virtudes esperadas dele - virtus, clementia, iustitia e pietas (bravura, clemência, equidade e sagrada devoção) ${ }^{63}$. Sua vitória militar associou-se à noção de bem-aventurança (felicitas) e intermediação entre Roma e os deuses condição oficializada anos mais tarde (12 a.C.), quando se tornou supremo pontífice (pontifex maximus) ${ }^{64}$. A mudança de uma libertas republicana para o obsequium (deferência, obediência) representou transformações conceituais e sociais perante o comando de um soberano $0^{65}$, um deslocamento da auctoritas do Senado para o Princeps e uma transformação conceitual e política ${ }^{66}$, não obstante originada de concepções tradicionais: o abandono completo destes valores poderia lançar a população e as gerações mais novas da aristocracia senatorial em uma incerteza sobre o seu próprio futuro ${ }^{67}$.

Em suma, o que Augusto propôs em 27 a.C. foi - após demonstrar que a res publica enquanto conjunto da comunidade e de seus assuntos políticos havia sido restabelecida à ordem - um compromisso pela manutenção dessa ordem mediante a revalorização dos princípios e costumes que regeram esta mesma comunidade outrora; o Princeps convidou o Senado e o povo de Roma

\footnotetext{
60 GALINSKY, 1996, p. 12-20.

${ }^{61}$ CROOK, 2008, p. 121; GALINSKY, 1996, p. 14

62 LOBUR, 2008, p. 23-30.

${ }^{63}$ CROOK, 2008, p. 79; SYME, 1939, p. 449.

${ }^{64}$ ANDO, 2000, p. 283-5; SYME, 1939, p. 446-8.

${ }^{65}$ EHRENBERG, 1984, p. 109.

${ }^{66}$ CASINOS MORA, 2000, p. 5.

${ }^{67}$ ECK, 2007, p. 47-8.
} 
para cooperar com o seu arbítrio (arbitrium) baseado na lei (ius) e no zelo (cura) em prol do bem comum ${ }^{68}$.

Os arranjos políticos de 27 a.C. podem ter tornado a supremacia de Augusto menos latente ${ }^{69}$. Todavia, estes ainda continham um aspecto que representava um obstáculo e eminente fonte de oposição: sua repetida permanência no consulado era um entrave para a ascensão dos demais candidatos, principalmente por Augusto sobrepor-se aos seus concorrentes em auctoritas $^{70}$. Os afazeres nas províncias mantiveram o Princeps ligeiramente afastado deste problema até o momento em que, diante de uma séria enfermidade, Augusto adoeceu, levando à tona o problema da sucessão - ou da continuidade da própria posição política alcançada. Diante de uma enfermidade, em 23 a.C., Augusto designou todas as responsabilidades do ofício para seu colega de consulado, Lúcio Cornélio Piso, e o seu anel de sinete (símbolo do consulado) para o general Agripa; nenhuma menção fora feita neste momento ao virtual sucessor, seu sobrinho Gaio Marcelo, fato que demonstrou ser uma grande jogada política, por evitar burburinhos sobre incipientes pretensões dinásticas ${ }^{71}$.

Recuperado, no mesmo ano Augusto abdicou do consulado, rompendo uma permanência de sete anos consecutivos no cargo. Todavia, por definição, o seu imperium proconsular não o permitia exercer o poder executivo dentro do limite urbano (pomerium) de Roma. Primeiramente, Augusto recebeu do Senado a ampliação deste poder, precedendo em autoridade os demais governadores provinciais e por mais dez anos. Do mesmo modo, o Senado autorizou o Princeps a compartilhar este mesmo poder com Agripa ${ }^{72}$, embora a esfera de atuação deste tenha sido limitada às províncias do Oriente e por apenas cinco anos, terminando assim antes do período concedido a Augusto ${ }^{73}$. Mais importante, as limitações do imperium foram abolidas com a concessão

\footnotetext{
${ }^{68}$ GALINSKY, 1996, p. 65.

69 idem, 1996, p. 66.

${ }^{70}$ BRUNT; MOORE, 1983, p. 10.

${ }_{71}^{71}$ CROOK, 2008, p. 83; EDER, 2007, p. 25-6.

${ }_{72}^{72}$ ADCOCK, 1989, p. 109-10; GRANT, 1949, p. 118.

${ }^{73}$ Para Werner Eck $(2007$, p. 66), as circunstâncias que representaram a atribuição do imperium para Augusto e Agripa demonstraram claramente a hierarquia existente na distribuição do poder a partir de então: no cume do poder imperial passou a haver ao menos uma pessoa de posse de poderes extraordinários, tornando possível a irrupção de distúrbios civis e militares caso Augusto subitamente morresse.
} 
do poder tribunício (tribunicia potestas) vitalício ${ }^{74}$. Esta concessão foi uma inovação dentro da instituição republicana do tribunado da plebe, da qual ainda como triúnviro Augusto já se valia do direito de auxílio (ius auxilii) aos cidadãos sob sua proteção.

Agora, ele podia atuar como um tribuno, impor veto às medidas legislativas senatoriais consideradas abusivas, bem como oficializar-se enquanto o grande responsável pela proteção (tutela) militar e moral da população romana ${ }^{75}$. O Senado leh concedeu ainda o poder de convocar a assembleia popular e o Senado sempre que desejasse, bem como a autoridade de propor leis para discussão (ius cum plebi agendi, ius cum senatu agendi), embasando legalmente suas ações políticas.

O poder tribunício tornou-se 0 pilar de sustentação do Principado ${ }^{76}$, aparecendo permanentemente na nomenclatura de Augusto a partir de 22 a.C., e contabilizando seus anos de governo ${ }^{77}$. Curiosamente, o tribunado da plebe nunca foi bem visto pelos senadores republicanos e raramente foi ocupado por patrícios, e o fato de exercer o poder de tribuno sem depender do cargo uma distorção neste ofício. Contudo, a partir de então Augusto liberou o caminho para as eleições consulares, e tribunicia potestas e imperium proconsulare maius tornaram-se fórmulas políticas duradouras para a autoridade executiva dos Imperadores ${ }^{78}$.

Entretanto, a posição política de Augusto não estava plenamente assegurada. Os problemas de abastecimento de grãos para a plebe de Roma sempre receberam paliativos. Agravada por uma sucessão de epidemias, o racionamento de alimentos extremou a insatisfação da população, exigindo que - Princeps retornasse de suas campanhas nas províncias e resolvesse o problema pessoalmente; em 22 a.C. Augusto e Agripa tiveram de retornar à Roma para conter a desordem popular. A plebe teria pressionado o Senado a conceder a Augusto o poder ditatorial, bem como o cargo de censor vitalício e o consulado perpétuo: prerrogativas maiores e mais evidentes que outrora, mas por ele recusadas.

\footnotetext{
${ }^{74}$ Agripa também recebeu o poder tribunício renovável em 18 a.C.

${ }^{75}$ ADCOCK, 1989, p. 109.

${ }_{77}^{76}$ EDER, 2007, p. 26.

${ }_{77}^{7}$ Após a divulgação da Res Gestae Divi Augusti.

${ }^{78}$ CROOK, 2008, p. 87; p. 118; ECK, 2007, p. 65-6.
} 
É difícil afirmar que tanto as ofertas quanto as recusas de poderes teriam sido maquinações, ou atestar igualmente que as primeiras teriam sido armadilhas de eventuais opositores; a resolução dos problemas estruturais da capital era uma demanda iminente. Ao aceitar a responsabilidade pela supervisão das provisões (cura annonae), o problema foi rapidamente sanado; foi criado também um comitê anual de senadores seniores responsáveis pelo aprovisionamento e distribuição de grãos em Roma ${ }^{79}$.

Por outro lado, Augusto se negou a conduzir um novo censo, e junto de Agripa partiu rumo à fronteira da Pártia com o intuito de restabelecer os estandartes militares perdidos em combate. Contudo, mais uma vez tiveram de retornar: os censores selecionados não conseguiram empreender o censo e as eleições consulares de 20 e 19 a.C. foram caracterizadas por tumultos. Ao que parece, a presença do Princeps e sua intervenção perante a plebe era cada vez mais requisitada. De todo modo, ao chegar a Roma, Augusto teria sido saudado pelos mais eminentes senadores, pelos pretores e tribunos da plebe. Seu regresso foi consagrado com um altar à deusa Fortuna (Fortuna Redux), e oficializado como feriado durante o resto de seu governo, com jogos e sacrifícios públicos à sua pessoa (Augustalia).

Diante desta conjuntura, o Senado concedeu a Augusto novas prerrogativas ao seu proconsulado: o seu imperium, agora vitalício, passou a valer também dentro da Cidade de Roma ${ }^{80}$. Ampliado o escopo de sua ação política, a Augusto foi dado o direito de sentar-se na cadeira do cônsul (sella curulis) e de ser acompanhado de doze litores. Revestido dos maiores símbolos desta magistratura, seu poder agora era equivalente ao dos cônsules e, somando-se à sua auctoritas, fundamentou-se sua dominância. Não se teve mais evidências de conflitos eleitorais em seu governo; sua posição política essencialmente alcançou em 19 a.C. sua forma final, cujas competências serviram de embasamento para os seus sucessores ${ }^{81}$ : Augusto foi um indivíduo privado (privatus) sem um cargo político e detentor de um enorme exército,

\footnotetext{
${ }^{79}$ CROOK, 2008, p. 96.

80 Junto de seu imperium proconsulare maius, passou a ser também renovado a cada cinco anos após 18 a.C.

${ }^{81}$ ECK, 2007, p. 67-8.
} 
situado em uma República cujos mecanismos políticos estiveram entrelaçados por sua auctoritas ${ }^{82}$.

A supremacia militar se manteve ao longo destas duas primeiras décadas como o pilar de sua soberania, e a concentração da glória em sua pessoa foi um aspecto evidente em sua ascensão. $O$ último triunfo militar concedido a outro general que não Augusto foi dado em 19 a.C. a Cornélio Balbo, governador da província da África. A partir de então, todas as vitórias foram dedicadas ao Princeps, por duas razões: os maiores contingentes militares foram comandados por legados do Imperador e sob seu imperium proconsular, e todas as províncias sob seu comando foram pacificadas, com a exceção do llírico, cujo comando também foi concedido a Augusto em 11 a.C., e supervisionada desde então por um de seus legados.

Todavia, mais importante foi o fato de que mesmo compartilhando do imperium com Augusto, Agripa - o mais próximo em poder e prestígio de Augusto - também recusou inúmeros triunfos. Consequentemente, todas as vitórias foram dedicadas a Augusto (21 aclamações até a morte de Agripa em 12 a.C.). Posteriormente, somente Tibério (7 a.C.) foi ovacionado como imperator pela vitória contra os germanos, e os anos que se passaram consolidaram a fórmula de que tanto o comando do exército e o desígnio da vitória pertenciam apenas ao Princeps e membros da família imperial. Aos demais, combater pelo Imperador valia uma insígnia triunfal (ornamenta triunfalia), embora esta também representasse enorme prestígio aos seus detentores ${ }^{83}$.

A partir de 17 a.C., o processo de associação entre Roma e Augusto alcançou um patamar sem precedentes: outro indício de legitimação do poder é observado com o anúncio e realização dos jogos seculares ${ }^{84}$ (/udi saeculares). Sob este pretexto, e como líder do colégio sacerdotal dos quinze homens (quindecemviri sacris faciundi), Augusto e Agripa celebraram durante quase dois meses um grande festival de jogos, sacrifícios e teatro. Em adição aos principais deuses da República, grandes celebrações foram feitas a Apolo patrono do Princeps - e sua deusa-irmã Diana.

\footnotetext{
${ }^{82}$ EDER, 2007, p. 27.

${ }^{83}$ ECK, 2007, p. 69-71.

${ }^{84}$ Diante da tradição etrusca que enunciava que o tempo de um povo era cíclico e secular, quando o último remanescente de uma era morria, uma nova se anunciava.
} 
A falência dos valores morais da aristocracia senatorial durante o fim da República serviu como pretexto para a difusão de um programa de restauração do prestígio e autoridade deste segmento social. Em contrapartida, uma vez que este conjunto de medidas foi atribuído à responsabilidade do Princeps, abriu-se um caminho para que simultaneamente fosse legitimada a transferência desta autoridade para o soberano. Disseminado como uma reforma dos costumes (mores), este movimento agregou transformações nas tradições, leis, e em outras concepções que compuseram a cultura da sociedade romana imperial ${ }^{85}$.

Portanto, entre 18 e 17 a.C. observamos a concatenação de reformas sociais no ambiente público e privado, o que incluiu uma segunda revisão do rol senatorial. Em termos deliberativos, o conjunto de leis (leges lulia) propostas mediante o poder tribunício de Augusto referia-se majoritariamente a dois temas: a manutenção dos organismos políticos e jurídicos romanos, condenações por adultério e punições para a baixa natalidade da aristocracia.

Para nós, o primeiro tema é mais importante, por abarcar uma série de leis que visou - inspirada nos tradicionais preceitos da República - o aprimoramento do sistema administrativo e judicial que perdurou durante o Principado; e a revisão do Senado, cuja redução para trezentos membros teve como mote a recuperação do tradicional prestígio da instituição, com seus ocupantes tendo mantido os principais cargos, o comando das legiões e os governos provinciais, bem como o recebimento de comissões e embaixadas periodicamente ${ }^{86}$. Esta reforma, além de resgatar o prestígio da instituição, alçou a ordem senatorial a um patamar que a distanciou nitidamente das demais ordens sociais.

Em verdade, as prerrogativas políticas de Augusto praticamente não sofreram maiores alterações após 19 a.C., salvo a sua eleição como supremo pontífice (pontifex maximus) em 12 a.C., após a morte do ex-triúnviro e ostracizado Lépido. Embora o colegiado pontífice tenha aparecido timidamente até então, o Princeps tornou-se o supremo sacerdote da religião romana e o grande intermediário entre os deuses. Ao realçar mais este elemento da tradição republicana e agregá-lo para si, Augusto ampliou o culto a Júpiter

\footnotetext{
${ }^{85}$ WALLACE-HADRILL, 1997, p. 10-15.

${ }^{86}$ CROOK, 2008, p. 92-3.
} 
(lupiter Optimus Maximus) mediante o resgate do sacerdócio dedicado a este deus (flamen Dialis). Igualmente, o Princeps tornou-se responsável pelas virgens vestais: estas mantinham acesa a chama sagrada que representava a perenidade da República e eram representadas como protetoras de Roma. Junto a isto e conforme a tradição, Augusto associou parte de sua residência ao pontificado e tornou-a pública; e associou sua esposa Lívia à proteção da chama vestal, fazendo com que esta adquirisse também um prestígio e influência política quase tão forte quanto o do Imperador.

O impacto religioso foi também político: ao tornar sua residência um ambiente sagrado, fazer de si e sua esposa os principais protetores do sagrado, e por sua morada estar próxima do fórum ${ }^{87}$, o seu ambiente privado converteu-se em parte do espaço público. Desta forma, a repetição destes atos simbólicos ampliou a dimensão de sua posição, intensificando sua identificação com Roma perante a população ${ }^{88}$.

Por fim, em 2 a.C., o senador Marco Valério Messala Corvino, colega de consulado de Otávio em 31 a.C., apresentou ao Senado uma resolução, propondo que Augusto - como consenso desta instituição, da ordem equestre e da plebe - recebesse a aclamação de "pai da pátria" (pater patriae). Esta aclamação representou uma honra - de enorme importância, pois foi uma extensão da designação parens ${ }^{89}$ patriae que fora conferida anteriormente a Caio Mário, Cícero e Júlio César - mas não um poder institucional formal ${ }^{90}$. Com esta designação, Augusto tornou-se o primeiro cidadão e pai de uma família: a seguridade de Roma havia tornado-se sua principal causa e a de todos os romanos que, por intermédio de sua previdência e sábia antecipação (providentia), tomaram sua figura de um primeiro entre os iguais (primus inter pares) como um referencial de comunidade endossada por sua auctoritas ${ }^{91}$.

\footnotetext{
${ }^{87}$ De acordo com Crook (2008, p. 102), o fórum de Augusto é um edifício de enorme representatividade, pois sua estrutura arquitetônica e seus detalhes artísticos enfatizam a noção da vitória em uma longa e bem-sucedida trama do imperialismo romano, cujo expoente final é o próprio Imperador; esta representação provavelmente surtiu um grande efeito na comunidade, pois o prédio passou a ser constantemente utilizado para as questões deliberativas e julgamentos.

${ }^{88}$ ECK, 2007, p. 74; SYME, 1939 , p. 446-8.

89 Parens pode ser compreendido tanto como 'parente' quanto 'pai'. Cf. Oxford Latin Dictionary, 1982.

${ }^{90}$ CROOK, 2008, p. 102.

${ }^{91}$ ECK, 2007, p. 75.
} 
Gradualmente, e de acordo com as circunstâncias políticas do momento, Augusto promoveu uma combinação de todos os títulos e prerrogativas asseguradas pelo mote da manutenção da tradição republicana. O Princeps entrelaçou-se com a organização financeira, militar e administrativa do Império Romano ${ }^{92}$ e conseguiu, ao longo de duas décadas, determinar os primeiros e principais componentes do Principado. Efetivamente, o Princeps deteve duas responsabilidades bastante pragmáticas: zelar pela Cidade de Roma e seus habitantes e proteger o Império frente às ameaças externas. Sua empreitada política foi claramente coercitiva, intransferível, e calcada no particularismo de sua iniciativa: ao longo dos anos Augusto decidiu como as outras esferas de participação política e seus agentes se coligariam ao seu comando.

Sua hegemonia sustentou-se, antes de tudo, pelo controle do exército, que desde o período triunviral esteve sob sua iniciativa e patrocínio, cujas recompensas posteriores - doações, recebimento de propriedades, aposentadorias - somaram-se à possibilidade que vários destes soldados adquiriram de ascender social e politicamente dentro dos cargos equestres, constituindo uma nova ordem social, composta de soldados comuns com possibilidade de ascensão, um caminho que séculos mais tarde tornar-se-ia proeminente na administração imperial ${ }^{93}$.

Após a vitória no Áccio, o exército tornou-se também um organismo profissionalizado, composto por legionários e aspirantes que se mantiveram leais à sua pessoa e à família imperial, comandados oficialmente por seu imperium, aprovisionados pelo erário público e dispostos por todo o Mediterrâneo, sobretudo nas fronteiras. Todavia, estas atribuições foram desempenhadas e divulgadas como a tutela de um pai (pater familias) perante seus filhos, os habitantes do Império, não obstante o soberano devesse primar pelo comedimento no uso de sua autoridade e, portanto, em sua conduta administrativa, uma vez que sua figura pública era inevitavelmente avaliada por seus concidadãos: senadores, equestres, soldados e a plebe ${ }^{94}$.

\footnotetext{
${ }^{92}$ EDER, 2007, p.31.

${ }^{93}$ SYME, 1939, p. 352-3.

${ }^{94}$ PEACHIN, 2006, p. 148-9.
} 


\section{2 - Os mecanismos de legitimação do poder de Augusto}

Com Augusto, Roma se tornou o imperium populi Romani, o poder exercido pelo Imperador e os romanos em seu mais amplo sentido ${ }^{95}$; imperium passou a significar também a dignidade e o poder absoluto do imperador ou: 0 Império ${ }^{96}$. Todavia, nenhuma palavra sumarizou perfeita e completamente a formação e o conjunto do poder de Augusto em seu período. A historiografia posterior anacronicamente atribuiu o termo 'Imperador' como uma espécie de síntese, condensando a trajetória de formalização e acentuando, conforme a distância temporal, o caráter monárquico do Principado ${ }^{97}$.

O estabelecimento do Principado foi processual, mas sob Augusto temos uma ruptura definitiva com o sistema político republicano, não obstante seja difícil resgatar uma constatação explícita na narrativa literária de seus contemporâneos, a adaptação dos ideais republicanos aos interesses do presente não obstruiu a percepção de que o poder decisório não consistia mais de uma multiplicidade de pontos de vista ardorosamente debatidos nos fóruns e assembleias, mas sim da decisiva influência e palavra final do Princeps ${ }^{98}$.

Embora todos os ambientes de deliberação republicanos tenham permanecido ativos (câmara senatorial, fórum e assembleia popular), as intenções do Princeps, publicamente manifestadas, fosse por ele, um meio a um ou mais comitês de amigos e associados (o consilium principis), ou entre os corredores do palácio imperial e a câmara senatorial passaram a ter força de lei, bem como poder de favorecer ou obstruir o futuro político de jovens senadores e equestres aspirantes às magistraturas, ou de senadores experimentados ao pretorado e ao consulado.

Como grande administrador e juiz, uma das atribuições essenciais de Augusto foi o atendimento aos cidadãos do Império. O envio e recebimento de correspondências de indivíduos, cidades ou grupos específicos, eram formalmente intermediados por embaixadores, embora a presença de governadores provinciais também fosse comum, de acordo com os interesses

\footnotetext{
95 LINTOTT, 1981, p.53.

${ }^{96}$ EHRENBERG, 1984, p. 121.

${ }^{97}$ EDER, 2007, p. 15.

${ }^{98}$ ADCOCK, 1989, p. 119-20.
} 
em questão. A leitura e resposta das correspondências, e o atendimento pessoal estiveram sujeitos a uma grande quantidade de solicitações, e principalmente à relação de importância ou proximidade do Princeps, da corte imperial ou de seus subordinados ${ }^{99}$. As audiências (cognitiones) envolviam vários indivíduos ou embaixadas em um mesmo assunto, e os decretos desenvolvidos entre estes, o Imperador, seus conselheiros, e o Senado. $O$ veredito era formalmente proferido, escrito e assinado por ambas as partes, conquanto provavelmente não tenha existido um protocolo específico: não é possível determinar se as correspondências chegavam ou eram lidas a ele sem intermediações $^{100}$.

Outro componente essencial de sua administração foi 0 frequente envolvimento nas diversas deliberações - algumas abertas, outras secretas sobre o cotidiano imperial, fossem no Senado, no auditório do palácio, ou mesmo em espaços semipúblicos ${ }^{101}$. Augusto diariamente recebia petições (libellum), e contava com o auxílio de senadores, conselheiros, libertos imperiais e amigos para a promulgação de editos (edictum) que respondiam a uma expectativa geral dos habitantes do Império, que o caracterizaram como um líder disposto a atender suas solicitações, dado o compartilhamento de noções e valores comuns sobre o funcionamento da sociedade romana ${ }^{102}$. A participação do Princeps em grandes ou banais questões jurídicas demonstrou que este se tornou o grande referencial da justiça e das leis no Principado, embora o Senado tenha ascendido como corte judicial, especialmente pela quantidade de condenações por traição ou corrupção, e pelo veemente estímulo do Princeps para que esta instituição se fizesse presente na maior parte dos negócios públicos.

Reforçados os meios, era preciso administrar os mecanismos de comunicação e seus fluxos de emissão e recepção. Augusto demonstrou uma grande preocupação com o principal meio de transporte e comunicação do período: as estradas. Em 20 a.C., após tentar dissuadir o Senado sem sucesso para que seus membros auxiliassem financeiramente a reparação de antigos e a construção de novos trechos, o Princeps assumiu pessoalmente a

\footnotetext{
${ }^{99}$ MILLAR, 1977, p. 211-17.

100 MILLAR, 1977, p. 219; TURCAN, 1987, p. 63-5.

101 MILLAR, 1977, p. 222-30; TURCAN, 1987, 63-5.

102 MILLAR, 1977, 235-42; p. 271.
} 
responsabilidade pelas estradas (cura viarium), transferindo enormes somas para o erário público (aerarium Saturni). Consequentemente, em 16 a.C., mediante decreto senatorial, Augusto designou um grupo de senadores para tal função, os curatores viarum, fiscalizando os oficiais nas localidades provinciais para a manutenção das estradas ${ }^{103}$.

As correspondências, os editos e leis informavam a situação política e efetivavam o controle administrativo (bastante rudimentar e apoiado principalmente na patronagem imperial, cujo cerne foi sua corte, conforme veremos abaixo) nas mais distantes regiões do Império. Deste modo, confirmou-se a importância de um contato escrito perene com a elite senatorial e equestre distribuída na Itália e nas províncias, posto que, junto dos decretos senatoriais, os escritos imperiais tornaram-se os mais importantes mecanismos do poder legislativo. Em contrapartida, os representantes do Imperador, grupos e indivíduos dentro das províncias também necessitavam de contatos e consultas ao Princeps; o sistema de postagem imperial (cursus publicus) auxiliava no contato entre centro e periferia, o intercâmbio da documentação escrita contribuiu para a vinculação do soberano e seus governados, e consequentemente como instrumento de manutenção da ordem política dentro do território romano ${ }^{104}$.

Desta maneira, o controle da força e a supervisão dos mecanismos administrativos e de comunicação relacionaram-se com sua posição de patrono universal. A reciprocidade foi necessária para assegurar a existência de uma rede de associados, clientes e amigos em Roma e por todo o Império ${ }^{105}$, reforçada por três componentes entrecruzados que se mantiveram durante todo o Principado: a exploração de componentes simbólicos e performativos que reiteraram a hegemonia de sua posição, o desenvolvimento de uma rede de patronagem, e o surgimento de uma corte imperial. É importante ressaltarmos esta especificidade, pois diferentemente das sociedades modernas, a soberania do Princeps não foi formalmente reconhecida como uma representação administrativa dentro de uma esfera institucional abstrata, e que continha em si a regulamentação de seus deveres e limites.

\footnotetext{
${ }^{103}$ ECK, 2007, p. 95.

104 MILES, 2000, p. 36-53.

105 CROOK, 2008, p. 113-117.
} 
A incerteza constituída pelos turbulentos últimos anos da República foi rearranjada sob Augusto mediante um posicionamento político conservador: este soube explorar a imagem de um líder que respeitava os costumes dos ancestrais (mos maiorum), combiná-la com uma autorrepresentação de restituidor da grandeza de outrora, e fazer de seu poder algo permanente e intransferível; seu posto (statio) estava relacionado ao carisma político endossado por suas virtudes, cujo elo foi sua auctoritas ${ }^{106}$. O restabelecimento da moral romana provocou uma reviravolta no pensamento da coletividade: 0 autoengrandecimento dos generais republicanos foi substituído pela veneração de um líder escolhido pelos deuses, a ostentação individual pela publica magnificentia (magnificência pública em obras, jogos e festivais), e a imoralidade por uma renovação espiritual e religiosa; uma interação entre a imagem projetada pelo Imperador e as honras a ele concedidas de modo relativamente espontâneo, um processo gradualmente desenvolvido ao longo dos anos ${ }^{107}$.

Desde então, observou-se um movimento agregador de certos padrões culturais. Embora a influência da arte helenística já estivesse presente nos dois séculos anteriores, Roma tornou-se um cerne de desenvolvimento e difusão cultural, cujos elementos centrais foram o Imperador e a res publica, e para além das áreas mais diretamente relacionadas com a celebração e o culto ao soberano; em uma sociedade orientada a partir de seu vértice, a imagem de seu líder tornou-se um modelo para seus indivíduos e que, mediante adaptações simbólicas, estendeu-se para várias esferas do cotidiano, tendo abarcado uma gama de valores e virtudes cívicas.

A simbiose de elementos gregos e romanos combinou-se à exaltação dos princípios morais e prosperidade universal, que do público inicial restrito à Cidade de Roma ampliou-se rapidamente para o restante do Império ${ }^{108}$. Esta estivera sujeita a contínuas transformações e acentuações, uma vez que nas províncias as qualidades do Imperador como um líder militar detiveram um peso maior do que o lado civil do Princeps (importante em Roma), impondo-se no sentido de uma simplificação e proliferação; os ritos do culto imperial,

\footnotetext{
${ }^{106}$ CROOK, 2008, p. 117; p. 121.

107 ZANKER, 1988, p. 2-3; SYME, 1939, p. 444-50.

${ }^{108}$ ZANKER, 1988, p. 334-35.
} 
festivais e elementos arquitetônicos tornaram-se mais frequentes e, consequentemente, mais parecidos ${ }^{109}$.

Não exageremos, contudo, o dinamismo e o alcance do sistema de comunicações imperial, e tampouco nos esqueçamos de que a oralidade predominou sobre a palavra escrita. Evidentemente, era de interesse do Imperador que sua pessoa representasse a personificação das maiores virtudes romanas, que seus governados compreendessem este fato e, sobretudo, que esta constelação de virtudes não ultrapassasse os limites da família imperial. Embora nem todas as virtudes fossem rigidamente divulgadas na mesma proporção (sua promoção dependia das circunstâncias políticas de cada ocasião), e as evidências literárias sobre a cunhagem imperial sejam pouco esclarecedoras, as moedas prefiguravam os principais ideais imperiais: equidade, devoção política-religiosa, bravura, generosidade, previdência e pudicícia/moralidade (aequitas, pietas, virtus, liberalitas, providentia, pudicitia) 110

Esta imagem de mantenedor da harmonia e do consenso precisava ser constantemente divulgada, mas este ímpeto não se originou com Augusto. A aclamação pública do poder foi um fato perene na política romana, e a ratificação da necessidade de seu controle pelas mãos da aristocracia sempre explorada em cerimônias religiosas, dedicações, jogos públicos, teatro e na literatura. Era necessário celebrar a harmonia entre todos os segmentos sociais da sociedade romana, e ao mesmo tempo confirmar que sua elite era o grupo mais apto para manter o bem-estar da Res Publica; as cerimônias públicas eram a arena da vida política republicana, centros de poder onde as ideias centrais da cultura romana encontravam expressão, cuja interação entre aristocracia e plebe fornecia para a primeira um reflexo de como esta era reconhecida pelo restante da sociedade ${ }^{111}$. Neste sentido, o fim da República e o início do Principado representou a transferência do controle dos meios de comunicação política e da ressonância de suas celebrações para Augusto - a partir de precedentes estabelecidos por Caio Mário, Sula, Pompeu e César -, e firmando-se, junto da família imperial, como principal interlocutor entre a elite e

\footnotetext{
109 ZANKER, 1988, p. 337.

110 NOREÑA, 2001, p. 159-60; SYME, 1939, p. 446-8.

111 SUMI, 2008, p. 2-12; p. 264.
} 
a plebe, assegurando uma nova posição de patrono universal do Império Romano ${ }^{112}$.

A celebração do consenso serviu inclusive como mote para acirrar a oposição de Augusto contra Marco Antônio: ao explorar a predileção deste último por vários elementos da cultura helenística - principalmente o fato de este último ter se deslocado para o Egito, estabelecer-se em Alexandria, construído uma aliança política com Cleópatra, e adotar explicitamente costumes e rituais monárquicos -, teria sido mediante a defesa dos valores republicanos que Augusto, de uma frágil representatividade perante o Senado, passou para defensor da República contra a ameaça de uma tirania. Do triunvirato até sua ascensão, e durante o restante do seu governo, o uso do passado - um passado de feitos exemplares, anterior às conturbações das guerras civis - visou à validação das ações no presente; a celebração de suas ações, o conjunto de novos elementos arquitetônicos, o cotidiano de Roma e do Império, tudo passou a fazer parte de um continuum entre um passado glorioso, a estabilidade (pelo consenso), e a promessa de um próspero futuro ${ }^{113}$.

O conjunto de transformações neste período permitiu que Augusto patrocinasse, promovesse e conduzisse a reapropriação dos usos do ideário republicano. O seu Principado carregou os preceitos políticos familiares no discurso de todos os segmentos que, ao longo do último século, disputaram o poder: uma leitura da res publica que assegurasse, mediante o consenso de toda a coletividade (consensum omnium ou universorum) que as práticas de um determinado grupo em conflito melhor representavam a continuidade dos costumes romanos ${ }^{114}$. Vencedor, Augusto e seus associados se valeram de inúmeros agentes em Roma e nas províncias para revestir sua hegemonia com elementos que trouxessem credibilidade às mudanças que gradualmente introduziu em seu novo sistema de governo, realçando a crença de sua legitimidade perante os governados, dentro e fora da cidade de Roma.

Mantenedor do ideário republicano que primava pela preservação do consenso, Augusto intensificou as celebrações públicas como forma de reforçar

\footnotetext{
${ }^{112}$ SUMI, 2008, p. 12.

113 idem, p. 268.

114 LOBUR, 2008, p. 3-5; p.8.
} 
sua representação como soberano: todos os cerimoniais, dedicações, consagrações, festivais, e obras públicas primaram por uma mudança que exaltasse a harmonia do presente - consequentemente relacionados à sua pessoa e da família imperial; estas celebrações não foram empreendidas exclusivamente por Augusto, mas também pela elite, não obstante tenham contado com o apoio do Imperador $^{115}$. Diante deste cenário, o monopólio do consenso representou uma ruptura com a República, mas a necessidade de sua manutenção não se perdeu: Augusto ampliou sua difusão, condição possível pelo fato de possuir auctoritas, noção diretamente relacionada ao consensus $^{116}$.

Uma vez que consensus e auctoritas estiveram relacionados à figura do Imperador, a honos (honra, condescendência, respeito) representou o elo entre o primeiro e seus subordinados, elemento também presente na hierarquia social republicana, e constituída por vínculos de solidariedade e deferência horizontais e verticais ${ }^{117}$. Em parte, as relações de honra atenuaram a faceta do poder pautada no monopólio da força e o peso das exações, condições inerentes do rudimentar sistema de administração romana ${ }^{118}$. Em Roma, mesmo sendo um primus inter pares, o mais proeminente entre os seus concidadãos, Augusto evidenciou a civilitas (a virtude de portar-se em conformidade aos demais) e afastou a ameaça da tirania pela recusa (recusatio) de honras ou poderes que destoassem da tradição.

Esta dinâmica social - que envolvia a conferência de benefícios e demonstrações de gratidão - codificou a conduta que também auxiliou sua ascensão a possuir o semblante de legitimidade, fazendo do Princeps não um monarca, mas um soberano que assegurasse, a despeito de sua superioridade, respeito aos seus pares e aos seus valores ${ }^{119}$. Por outro lado, nas províncias a monarquia sempre foi um sistema político comum, do qual evidentemente Augusto também se valeu para fortalecer sua dominação territorial, econômica e militar.

\footnotetext{
115 idem, p. 3-5.

116 ibidem, p.9; p.29.

117 LENDON, 2005, p.16-18.

118 idem, p.128-9.

${ }^{119}$ BÉRANGER, 1953, p. 152-3, 219-20, 283-4.PEACHIN, 2006, p. 149-152.
} 
De todo modo, a manutenção da honoris de Augusto tornou-se uma questão imperial, uma maneira de conduzir os assuntos públicos e administrar um vasto território que necessitava da adesão de seus indivíduos, fossem eles membros da aristocracia senatorial ou equestres em Roma, indivíduos das elites provinciais, ou a plebe imperial. Têm-se a difusão de um cerimonial que demonstra simultaneamente distanciamento e aproximação, articulando duas diretrizes: a continuidade dos valores e tradições do passado republicano, o consentimento das ordens sociais, e a reprodução de uma estrutura social hierárquica como referencial de unificação em todas as comunidades do Império ${ }^{120}$.

O desenvolvimento da reciprocidade pelas relações de honra constituiuse como um mecanismo pelo qual o Imperador conquistou, na prática, a obediência de seus governados. Inúmeras comunidades demonstraram a aceitação desta condição, celebrando publicamente seu comprometimento consensual à nova ordem estabelecida, com uma grande variedade de receptores - diferentes indivíduos e grupos sociais espalhados em Roma e províncias - aos quais dedicações, templos, monumentos e celebrações públicas demonstravam a existência de um benfeitor e seus beneficiários ${ }^{121}$, competindo por honra, e reiterando a lealdade (fides) como uma das principais características da cultura política romana ${ }^{122}$.

Nada disso foi concebido ao acaso; uma vez mais observamos que a construção destas relações pautadas na honra, comprometimento e consenso possuem raízes no próprio passado romano. A partir do momento em que se lançou como triúnviro, Augusto explorou a predileção de Marco Antônio pela cultura grega - e especialmente de seus componentes monárquicos - para se colocar frente a seu opositor como líder pela preservação da contaminação da cultura romana. Sua percepção em relação a este fato - e o resgate de vários elementos da tradição esquecidos pelas disputas concentradas por poder até então - somou-se a um contexto que possibilitou de forma inédita que este patrocinasse, promovesse e conduzisse a reapropriação destes elementos, de modo que a transformação política endossada pelo Imperador correspondesse

\footnotetext{
${ }^{120}$ SYME, 1939, p. 365-6; WALLACE-HADRILL, 1982, p. 32-48.

121 ANDO, 2000, p. 131-2.

122 idem, p. 133-5.
} 
também a transformações nos usos do ideário romano. Uma vez mais, estas ideias foram moldadas a partir do segundo triunvirato, inspiradas em preceitos políticos comuns a qualquer um dos segmentos que disputaram o poder até então: uma leitura da res publica que asseguraria, mediante o consenso de todos/universal (consensum omnium ou universorum), que as práticas de um grupo representavam melhor a continuidade dos costumes romanos ${ }^{123}$.

Por outro lado, é importante compreendermos de qual população estamos falando, e qual é a medida plausível de sua efetiva participação política nesta sociedade. A maior parte das referências sobre a plebe urbana de Roma a caracterizava mais como um populacho - apático e volúvel - do que como indivíduos dotados de opinião política própria, principalmente durante o período imperial ${ }^{124}$. Talvez a população possuísse consciência de sua desvantagem perante $o$ aparato militar, o que parcialmente justificaria a escassez de menções a confrontos diretos; as manifestações populares geralmente consistiram de protestos ou insultos, e pautadas por insatisfações de ordem socioeconômica: excessos na tributação, enchentes, epidemias, incêndios, racionamentos ou carestia de alimentos, ou proibição de jogos e festividades.

Todavia, existiram momentos de ampla revolta ou comoção: o cortejo fúnebre e a deificação de Augusto, o luto por Germânico César, a revolta pelo banimento e posteriormente a morte de Agripina, a destruição de monumentos e a profanação do cadáver de Sejano após sua eliminação, ou mesmo as manifestações de alegria pela morte de Tibério ${ }^{125}$. Visível como grande grupo, o anfiteatro constituiu-se como o principal referencial da opinião da população, amplamente buscado pelo Senado republicano e posteriormente pelo Imperador; possivelmente este ambiente permitiu uma autoconfiança inexistente fora das aglomerações, cuja franqueza era mais visível. A possibilidade - bem como a necessidade - desta recepção talvez tenha justificado a permissividade de certos Imperadores mesmo diante de comentários negativos ${ }^{126}$.

\footnotetext{
${ }^{123}$ GALINSKY, 1996, p. 76; LOBUR, 2008, p. 3-5; p.8.

${ }^{124}$ YAVETZ, 1969, p.14-21.

125 idem, p.14; p.35-6.

${ }^{126}$ YAVETZ, 1969, p.21.
} 
Deste modo, o termo 'povo' apresenta-se mais como um conceito político e poder em potencial do que como um conjunto de indivíduos com real poder decisório. A representatividade do termo dentro do ideário romano foi na prática restringida pela aristocracia senatorial desde o início da República, com a existência de uma lacuna entre seu peso institucional e a representação cotidiana de seus interesses, condição que permaneceu também durante 0 Principado ${ }^{127}$. Isto se deveu à grande divisão socioeconômica, cujas demarcações dificultaram a integração entre a elite e o restante da população romana.

Em verdade, a atitude da primeira geralmente era de desprezo e quase nenhum senso de comunidade perante os grupos sociais inferiores; a população possuía outras formas de organização em seu cotidiano e que apenas pontualmente - mediante interlocutores, como clientes de um senador ou equestre - tocavam os interesses da aristocracia. Mesmo com a polarização política no final da República, em que segmentos da plebe urbana detiveram certo peso representativo - evidentemente mediante interlocutores e com os interesses focados na vitória dentro do próprio cenário político aristocrático - o povo de Roma nunca foi plenamente incorporado dentro do processo político. Embora não tenha havido nenhum mecanismo de exclusão formal, sua participação sempre foi desencorajada por uma variedade de razões institucionais e práticas, fundamentalmente embasadas na estrutura aristocrática desta sociedade ${ }^{128}$.

Sendo assim, o principal elemento agregador da sociedade romana, especialmente de seus segmentos mais distantes das relações cotidianas de poder (plebe, libertos e escravos) consistiu da religião e do culto imperial. A preocupação de Augusto em restaurar templos, reativar elementos do cerimonial religioso romano e de ressaltar o aspecto moralizante de suas reformas não foi acessória nem meramente estética: a religião e a res publica estiveram relacionadas desde o início, como fundamentação da estrutura, ordem e sentido da sociedade romana ${ }^{129}$.

\footnotetext{
${ }^{127}$ MOURITSEN, 2004, p. 14-17.

${ }^{128}$ idem, p. 136-48.

${ }^{129}$ GALINSKY, 1996, p. 287.
} 
A prática sociopolítica estabelecida por Augusto durante o seu governo não deve ser compreendida sem o discernimento de que esta estava imersa em componentes religiosos. Esta se desenvolveu gradualmente, adaptando-se a diferentes propósitos e necessidades; longe de ter sido rigidamente controlada do topo, ela deixou espaço para a múltipla iniciativa de toda a sociedade, tendo como resultado as redes de interações e reciprocidades, que em última instância tiveram o Princeps e sua auctoritas como cerne, e cujo resultado final foi a deificação de Augusto. Em contrapartida, é necessário ressaltar que em vida o culto não era feito à sua pessoa, mas sim aos deuses que estavam associados à sua augusta posição e para o bem do Imperador - e consequentemente do restante da população sob seu consenso - ou seja, pro salute Augusti e Pax Augusta ${ }^{130}$.

Antigos referenciais serviram para estimular novas práticas, principalmente dentro do culto privado: Augusto reativou os fratres arvales (irmãos dos campos cultivados), associando-se com os senadores das mais iminentes linhagens republicanas remanescentes (inclusive daquelas anteriormente opostas a ele), realçando as práticas religiosas desta irmandade aos seus êxitos políticos e, não menos importante, agregando os elementos festivos e ritualísticos ao bem-estar da família imperial ${ }^{131}$. Além disso, após ter tornado-se supremo pontífice em 12 a.C., Augusto deteve legitimidade para reorientar o antigo culto etrusco-republicano às divindades domésticas (lares ou genii loci) em toda a península itálica, tendo reorganizado sua administração em quatorze regiões e duzentos e sessenta e cinco bairros (vici), cujos lideres - remanescentes dos antigos collegia, majoritariamente libertos ou escravos adquiriram visibilidade social.

Com isto, a combinação do culto às divindades domésticas e aos ancestrais masculinos da residência foi acrescida do culto ao genium ("espírito") de Augusto, principalmente após este ter se tornado pater patriae em 2 a.C. ${ }^{132}$. O referencial do culto doméstico vinculara-se, portanto, à pessoa do próprio Princeps, e isto principalmente fora da Cidade de Roma: o estabelecimento de centenas de confrarias dedicadas ao culto de Augusto

\footnotetext{
${ }^{130}$ GALINSKY, 1996, p. 287; GRADEL, 2002, p. 138-9.

${ }^{131}$ GALINSKY, 1996, p. 288-93.

132 GALINSKY, 1996, p. 300-1.
} 
(sodalitates augustales) nas municipalidades da região ocidental do Império, coordenadas majoritariamente por libertos ricos, permitiu que estes adquirissem uma posição social proeminente (a despeito da impossibilidade de deterem magistraturas) entre os decuriões e a plebe ${ }^{133}$.

Originária dos cultos domiciliares ancestrais que remetem aos primórdios do período republicano, devemos ressaltar que o desenvolvimento de um culto ao genius do soberano vivo não foi algo plenamente definido já com Augusto. Em verdade, a delimitação desta prática só é perceptível com Cláudio, e somente ao final do segundo século uma definição constitucional formal do Imperador como chefe de um estado encarado como um grande domicílio se estabeleceu. Em contrapartida, desde então a noção do Princeps como um entre seus concidadãos já havia na prática deixado de existir, embora a ideia de um "bom" Imperador entre os mais proeminentes senadores tenha permanecido ${ }^{134}$. Como podemos perceber em relação à constituição dos frates arvales, a prática do culto adquiriu uma função política, sobretudo no plano da manutenção dos vínculos de patronagem e reciprocidade entre Imperador e aristocracia.

Com isto, conclui-se que o culto imperial foi um flexível sistema de intercâmbio entre Roma e as localidades provinciais, um elemento unificador em meio à diversidade que promoveu a presença de Roma e Augusto - um símbolo de identificação alçado pela dimensão carismática de seu soberano -, em que este último passou a figurar imponentemente em diversos panteões ao redor do Império; e um experimento que começou a partir de Augusto, e que se tornou uma condição (e uma expectativa) dos governados perante os sucessores da dinastia Júlio-Claudiana e futuros imperadores ${ }^{135}$.

\footnotetext{
133 idem, p. 310-20.

${ }^{134}$ GRADEL, 2002, p. 196-7.

${ }^{135}$ Cf. GALINSKY, 1996, p. 330-1.
} 


\section{3 - Augusto e a aristocracia em Roma}

Augusto não modificou profundamente a divisão social romana. Ao passo que a base desta consistiu de uma vasta população cuja participação política prática permaneceu restrita, a despeito da crescente importância dos soldados - cuja participação será determinante a partir do século terceiro - os cidadãos que permaneceram circunscritos ao poder foram os membros da ordem senatorial e equestre.

Em contrapartida, a difusão de um culto à imagem e à personalidade do Imperador, fato que representou o consentimento dos romanos ao restabelecimento da República sob a tutela de seu mais ilustre membro e de seus familiares, verificou-se por uma ampliação dos mesmos vínculos de interação sociopolíticos: a patronagem imperial conectou indivíduos em redes de solidariedade horizontais e verticais cujo cerne constituiu-se de seu principal benfeitor, o Princeps. Por meio da patronagem, Augusto pôde exercer sua soberania e regular o funcionamento da administração imperial, cuja manutenção foi de fato algo extraordinário, tendo em vista a existência de uma relação inversamente proporcional entre a extensão territorial do mundo romano e o contingente de homens delegados a esta função ${ }^{136}$.

Devemos ter em mente que a ênfase na patronagem imperial refere-se primordialmente às duas primeiras ordens sociais, não obstante os efeitos destas interações tenham influenciado também o restante dos governados ao redor do Império. Podemos definí-la como um conjunto de relações pessoais de reciprocidade assimétrica (diferentes status sociais) entre um patrono (benfeitor e protetor) e um cliente, cuja retribuição é composta por uma variedade de bens ou serviços ${ }^{137}$ que, a partir de Augusto, foram essenciais no âmbito das funções de um Imperador. A concessão de cargos para senadores e equestres foi uma das principais maneiras que o Princeps encontrou para demonstrar consideração pelos membros da elite romana, e uma das principais

\footnotetext{
${ }^{136}$ Cf. MILLAR, 2001, p. 312: [...] for it was precisely the fact that roman ranks, titles and posts, both new and old, could be conferred by the emperor, and in many cases could be and were sought from him by the beneficiaries, which gave a real or symbolic place within the Roman state to an ever-widening range of individuals, to their families and descendants, and in the long run to whole areas of society in the provinces. [...]

${ }^{137}$ SALLER, 1982, p. 1.
} 
formas de comunicação entre ambos, na medida em que estes últimos também buscaram favorecimento e acesso ao primeiro ${ }^{138}$.

A identificação destas relações nas evidencias literárias e epigráficas pressupõe um cuidado: patronus e clientes foram termos pouco utilizados na literatura, uma vez que a linguagem de subordinação era algo evitado pela aristocracia, enquanto que tais termos apareciam com maior frequência nas inscrições geralmente feitas por clientes, cuja dedicação era importante para exaltar publicamente o beneficiário e sua superioridade. Mais comum era a presença do termo amicus (amigo, aliado) tanto para patronos quanto para clientes, uma ambivalência que, a despeito de suas concepções filosóficas contemporâneas ao período imperial. Amicus pressupôs a existência de trocas de officia e beneficia, sendo que ambos os termos eram compreendidos tanto como 'deveres' quanto como 'favores', e sempre pautadas pela gratia (gratidão), e que por sua vez indicavam relações de patronagem ${ }^{139}$. Assim, gratidão (gratia) e benefício (beneficium) estiveram sempre presentes no contexto religioso, familiar, econômico (empréstimos, concessões, heranças) e político, pois o prestígio e influência de um senador republicano relacionavamse diretamente ao tamanho de sua clientela e ao poder de seus amici ${ }^{140}$.

Conforme mencionamos no subcapítulo anterior, dentre as principais virtudes imperiais divulgadas pelo Imperador, a liberalitas foi uma das mais significativas, devido à sua direta relação com a concessão de beneficium e com os vínculos mantenedores da patronagem na República e Principado. Amplamente aceita, a generosidade republicana é louvada - conforme Cícero $^{141}$ - por se equiparar à benignitas (benevolência) e à beneficentia (beneficência), e por permitir (se o seu uso não visar exclusivamente à autopromoção) a união da comunidade e o favorecimento espontâneo de seu preceptor.

Embora esta virtude tenha aparentemente entrado em declínio em paralelo aos conflitos no final do período republicano, a liberalitas e o ideal de concessão de benefícios foram resgatados por Augusto, não obstante a definição deste como o principal benfeitor da sociedade romana. Isto

\footnotetext{
${ }^{138}$ MILLAR, 2001, p. 275-6.

${ }^{139}$ ROULAND, 1971, p. 577; SALLER, 1982, p. 11-22.

140 SALLER, 1982, p.141.

${ }^{141}$ De Officis, 1.20;1.42; 1.44, apud MANNING, 1985.
} 
pressupõe que, a despeito da ascensão do Princeps e sua proeminência, a patronagem imperial não aniquilou a patronagem privada; tais práticas continuaram a moderar as interações entre indivíduos da aristocracia e seus dependentes, de modo semelhante como estes passaram a se relacionar com - Imperador, agindo em linhas políticas anexas, e em uma notável perenidade ${ }^{142}$. Embora haja uma profunda diferença entre teoria e prática, do mesmo modo que benignitas e beneficentia passaram a ser louvada nos Imperadores, sua presença ainda foi perceptível no ideário da aristocracia romana durante o Principado, que de modo semelhante à patronagem, continuou a ser um elemento de interação social, a despeito da posição do Imperador $^{143}$.

Com Augusto, a proximidade do Princeps tornou-se o principal elemento de valor na patronagem imperial, pois mesmo as decisões administrativas mais comuns não eram vistas como mecanicamente impessoais, mas como favores passíveis de gratidão e retribuição ${ }^{144}$ : posição, privilégios legais, magistraturas, cargos no exército e na administração, sacerdócios, benefícios financeiros (concessões fiscais e imunidades, subvenções após desastres naturais como terremotos e incêndios, doações para elevar ou manter a riqueza, liberalidades) e intervenções julgamentos (principalmente em casos de pena capital) estiveram à disposição do Imperador. A patronagem imperial tornou-se algo corriqueiro: demonstrações públicas de gratidão eram tidas como comuns, exceto quando o acesso de senadores ao Imperador dependia da boa-vontade de mulheres da família imperial, libertos ou escravos, o que denotava uma inversão da hierarquia social romana, algo condenável ${ }^{145}$.

Embora tenha se tornado o grande patrono, o Imperador evitou obstruir a possibilidade de membros da aristocracia de exercer a concessão de benefícios econômicos, legais e políticos em menor escala, precisamente pela falta de condições de prover e gerenciar uma hierarquia burocrática adequada e de larga escala. Mediante o vínculo com o soberano, senadores e equestres ilustres também puderam recomendar (commendare) subordinados: cônsules aparentemente podiam selecionar questores do grupo de senadores

\footnotetext{
${ }^{142}$ ROULAND, 1979, p. 499, 618-22.

${ }_{143}$ MANNING, 1985, p. 73-75; ROULAND, 1971, p. 506-8.

${ }_{144}^{14}$ ROULAND, 1971, p. 572-3; SALLER, 1982, p. 30-6; SYME, 1939, p. 381-2.

${ }^{145}$ SALLER, 1982, p.45; p. 56; MILLAR, 2001, p. 278; WALLACE-HADRILL, 2008, p. 296-7.
} 
ingressantes ${ }^{146}$; estes geralmente obtinham, mediante o fornecimento de um codicilo (codicilli), cargos civis e militares em províncias, dos quais se esperavam deferência e gratidão aos seus superiores e, por consequência, fortalecimento dos vínculos futuros de patronagem, de influência de seu patrono, bem como ampliação das redes de solidariedade em vários cantos do Império, principalmente pela presença de cargos militares protagonizados por equestres, que ampliavam a força destas interações nestas localidades ${ }^{147}$. Conquanto o corpo de oficiais imperiais fosse pequeno para abarcar e atender as demandas de seus governados, os vínculos de patronagem foram mecanismos interpessoais pelos quais estes últimos puderam manter contatos com a administração imperial ${ }^{148}$.

${ }^{146}$ SALLER, 1982, p. 130. Millar (2001, p. 284-7) oferece várias evidências para confirmar que, no caso dos equestres, a recomendação por parte do Imperador se estendeu a praticamente todos os cargos e funções políticas e militares que um cavaleiro pudesse exercer, em todos os seus níveis de prestígio e importância. Da mesma maneira, a capacidade de um senador em conseguir um favorecimento para outro equestre mediante solicitação pessoal ou escrita para 0 Princeps ou subordinado redundava em prestígio para o próprio senador.

${ }_{147}$ MILLAR, 2001, p. 288-91; SALLER, 1982, p. 131-8.

${ }^{148}$ SALLER, 1982, p. 205-6. 


\subsection{1 - O Senado}

Neste sentido, o Senado continuou a ser a mais importante instituição romana. É verdade que sua composição não permaneceu exatamente a mesma desde sua fundação, concomitante à fundação da própria República. Igualmente, o restabelecimento da República proclamado em 27 a.C. não foi a restauração do Senado em sua antiga composição: os nobres patrícios tinham deixado de ser maioria em meio a uma grande quantidade de homens novos $^{149}$, e o favorecimento tornou-se um fator definitivo para a carreira de um aristocrata, o que nos ajuda a compreender como futuramente o Senado contaria com membros de praticamente todas as províncias imperiais ${ }^{150}$ : a posição do Princeps continuou auxiliando o ingresso de novos senadores que pudessem, por competência e pela eficiência de seus préstimos, serem de grande valia para Augusto, e a constituição de uma ordem que demonstrasse diligência na administração imperial ${ }^{151}$.

Embora seja difícil estabelecer uma evolução precisa de seu funcionamento, durante o primeiro quarto do século I a.C., o Senado era composto de aproximadamente trezentos membros inscritos em uma lista (album) revisada quinquenalmente (a revisão [lectio senatus] durava até dezoito meses), por meio de um grupo de magistrados coordenados por dois censores - um dos mais ilustres cargos senatoriais, exercido somente por excônsules -, e que abarcava o recenseamento de membros da ordem senatorial, equestre, e dos demais cidadãos em cinco grandes grupos.

Inicialmente, tanto patrícios quanto equestres poderiam se tornar senadores caso possuíssem a quantia mínima de quatrocentos mil sestércios, além da ancestralidade; a divisão em ordens era uma definição censitária e jurídica, mas abrangia também distinção, prestígio social e hereditariedade de status; senadores apareciam em público vestidos de uma túnica adornada com uma lista púrpura debruada (laticlavus), enquanto equestres vestiam outra mais larga (angusticlavus), possuindo também um "cavalo público" e um anel de

\footnotetext{
${ }^{149}$ SYME, 1939, p. 372.

${ }_{150}$ ECK, 2007, p. 78-80. MILLAR, 2001, p. 290-1.

${ }^{151}$ NICOLET, 2001, p. 95.
} 
ouro; o contingente de ambas as ordens era composto massivamente por romanos e italianos ${ }^{152}$.

A primeira grande transformação no escol senatorial ocorreu durante 0 período de supremacia de Lúcio Cornélio Sula (88 - 79 a.C.), que proscreveu inúmeros senadores favoráveis a Lúcio Cornélio Cina e Caio Mário, usurpou a autoridade de censor e ampliou o quadro para seiscentos membros, com a admissão de inúmeros partidários, em sua maioria homens novos ${ }^{153}$ (novi hominis) que ascenderam pela primeira vez à carreira pública, mas que permaneceram em grande parte apenas como questores e sem poder de voto nas assembleias (senadores pedarii).

Sob os mesmos moldes de Sula, em 49 a.C. Júlio César proscreveu apoiadores de Pompeu e realizou outra revisão senatorial, agora com aproximadamente novecentos membros; equestres, legionários italianos e provinciais adentraram à instituição. Por último, seguiram-se os conflitos entre Marco Antônio e Otávio. Como resultado final, a grande mortandade e empobrecimento de antigas linhagens patrícias, a entrada de homens novos que assimilaram ideais patrícios, e vincularam-se matrimonialmente às famílias sobreviventes - entregou a Augusto um Senado bastante diferente de sua composição anterior ao começo das dissensões civis do último século republicano $^{154}$.

Apesar do novo sistema de governo, o objetivo de qualquer membro da aristocracia continuou a ser a ascensão dentro da carreira pública (cursus honorum), e o pertencimento à ordem senatorial ${ }^{155}$. Por volta de dezoito a vinte anos de idade, um senador começava sua carreira como um dos vinte vigintiviri (literalmente "vinte varões", colégio de magistrados responsáveis por funções como manutenção das ruas e estradas, policiamento, cunhagem, e litígios

\footnotetext{
${ }^{152}$ ALFOLDY, p. 121-36; CHASTAGNOL, 1992, p. 15-7.

153 De acordo com T.P. Wiseman (1917, p. 2-4), o termo homo novus tem uma denotação ambígua, se considerarmos o período final da República, pois se referia tanto a um candidato ao consulado cujos ancestrais, independentemente de terem sido senadores, não haviam sido cônsules, quanto a um senador cujos antepassados haviam sido equestres sem ingresso ao Senado. Não obstante este último significado tenha se referido mais propriamente aos indivíduos que conseguiram ascender significativamente a partir de Sula, em verdade a Guerra Social abriu o caminho para que um contingente de aristocratas italianos pudesse compor esta instituição, que outrora foi majoritariamente restrita às famílias aristocráticas da Cidade de Roma.

${ }_{154}$ CHASTAGNOL, 1992, p. 17-21; ECK, 2007, p. 78; SYME, 1939, p. 349-50 e p. 492-; WISEMAN, 1971, p.7-9.

${ }^{155}$ ALFOLDY, 1989, p. 135-6; TALBERT, 2008, p. 326-7
} 
judiciais). Em seguida, ele era designado para uma província como comandante militar auxiliar de uma ou tribuno de uma legião. Aos vinte e cinco, era formalmente eleito para o Senado como um dos vinte questores (supervisor financeiro), tornando-se posteriormente um edil (um dos seis responsáveis pela manutenção do patrimônio urbano e pelos festivais), ou então um dos dez tribunos da plebe - patrícios foram dispensados desta função por Augusto.

Aos trinta anos, o senador era autorizado a candidatar-se para as dez vagas de pretor (ou doze, número variável na documentação e de acordo com a época), ofício responsável por diversas funções administrativas e jurídicas que, sob Augusto, passaram a depender de sua recomendação, fosse abertamente, por indicação indireta ou encaminhada como nome em uma lista para o Senado (os candidatos recomendados pelo Imperador, candidatus Caesaris) ${ }^{156}$. Tendo sido pretor, o senador poderia ainda ser poderia ser procônsul, governador de uma província senatorial ou imperial (legatus Augusti pro praetore), ou comandante de legião (legatus legionis). Aos quarenta anos, pouquíssimos senadores disputavam o favorecimento do Imperador pelo cargo de cônsul ordinarius ou suffectus (designado).

Em 5 a.C., Augusto modificou o tradicional par de cônsules anualmente escolhido pelo hábito de substituí-los por outros, em intervalos variados, o que possivelmente atenuou a agressividade na disputa pelos cargos, e o fato de que o Imperador frequentemente ocupara este posto; já no governo de Tibério é provável que o consulado fosse uma concessão do Princeps, dado à quantidade de cônsules designados que assumiam o cargo durante o ano ${ }^{157}$. É difícil mensurar a intencionalidade desta modificação; da mesma forma que a ampliação do acesso a esta magistratura trouxe prestígio para mais senadores dentro da instituição e para o resto de suas carreiras, a diminuição do período de ofício reduziu efetivamente a influência política de um cônsul ${ }^{158}$. Como topo da carreira, os principais cargos da administração imperial continuaram a cargo

\footnotetext{
${ }^{156}$ BRUNT, 1984, p. 429. LEVICK, 1967, p. 228-30; MILLAR, 2001, p. 301-5.

157 MILLAR, 2001, p. 307. Um exemplo fundamental é oferecido nesse sentido: em 31 d.C., Sejano recebe o consulado de Tibério, sem ter exercido previamente nenhum dos cargos senatoriais: as distinções da ornamenti praetoria e consularia já eram tradicionalmente concedidas aos prefeitos do pretório, todavia estas condecorações - cujo conteúdo não é muito claro - não representavam formalmente pertencimento à ordem senatorial (MILLAR, 2001, p. 308 apud Passerini, 1939, 223. Isto torna compreensível o esforço de Veléio Patérculo (II. 1278) em justificar a dignidade alcançada por Sejano no período.

${ }^{158}$ ECK, 2007, p. 84-5; SYME, 1939, p. 420; TALBERT, 2008, p. 297.
} 
de senadores consulares, como as curadorias de Roma, governos das províncias, e a prefeitura da Cidade de Roma (praefectus urbi) ${ }^{159}$.

A busca por poderes e honras disponíveis se manteve em um ambiente de disputas acirradas, embora a energia dos embates tenha sido gradualmente canalizada do pleito nas assembleias populares para a busca por reconhecimento e favorecimento por parte do Princeps, seus familiares e apoiadores mais próximos; isto era perceptível principalmente entre as magistraturas menores, posto que a recomendação e indicação dos magistrados mais importantes tornou-se pouco a pouco uma ferramenta utilizada por Augusto como maneira de controlar o acesso - e as iniciativas dos homens - nestes cargos.

As eleições continuaram a ocorrer - sendo formalmente transferidas da assembleia popular para o Senado em 14 d.C. - mas, a prática da supervisão dos nomes indicados para a entrada anual na instituição, bem como a escalada para os cargos, estivera nas mãos do Princeps e de seus mais influentes magistrados. Fosse o jovem cidadão membro de uma antiga linhagem romana republicana, ou um homem novo, em cada uma das etapas do cursus honorum, a existência de uma proximidade do Princeps era um diferencial para o êxito ou a estagnação na carreira senatorial ${ }^{160}$.

Augusto reiterou a conservação dos preceitos romanos, a manutenção do suporte da aristocracia para a sua legitimidade, e sua própria identificação com a cultura política deste segmento social. Contudo, esta preservação representou um paradoxo permanente, e um compromisso instável na relação entre o Princeps e seus concidadãos, uma vez que inevitavelmente a presença soberana do Imperador conduziu este Senado a uma posição secundária no âmbito das decisões políticas ${ }^{161}$. Em outros termos, esta instituição teve o seu poder de oposição bastante atenuado: consciente de sua representatividade como ordem social, os poucos elementos que nutriram esperanças em uma mudança de quadro tiveram de dividir espaço com os homens novos italianos,

\footnotetext{
${ }^{159}$ ALFOLDY, 1989, p. 136.

${ }^{160}$ BRUNT, 1984, p. 429; LEVICK, 1967, p. 228-30.

${ }^{161}$ BURTON \& HOPKINS, 1983, p. 120-1; MILLAR, 2001, p. 351-2; VEYNE, 2002, p. 57-8; WINTERLING, 2010, p. 30-3.
} 
especialmente em posições de destaque determinadas pelo próprio Princeps, como o consilium e a corte imperial ${ }^{162}$.

Para além da relação cada vez mais estreita entre o favorecimento do Imperador e a ascensão na carreira senatorial, dois outros elementos foram decisivos para a caracterização do Senado com Augusto e, consequentemente, para o restante do Principado: um processo de revisão de sua composição e pertencimento, e a existência de um comitê de membros influentes interagindo sobre o restante dos demais senadores em assembleia. Entre 28 e 27 a.C., Augusto empreendeu um censo em que removeu quase duzentos membros da instituição, sob o argumento de que a conduta moral ou os critérios financeiros destoavam das dignidades da ordem; a maior parte dos destituídos retornou à antiga condição de equestre.

Evidentemente, a premissa do censo não se restringiu apenas a remover o excesso de homens novos que foram promovidos desde a ditadura de Júlio César; o intuito de reforma do Senado previu também a remoção dos aristocratas que não nutriam lealdade pelo Princeps, ou que eram ressentidos remanescentes da República e ex-simpatizantes de Marco Antônio ${ }^{163}$.

Em 18 a.C., após um malsucedido e derradeiro censo empreendido pelos cônsules em exercício, Augusto - tendo solicitado que voluntariamente outros senadores declinassem da posição pelos mesmos critérios - tentou sem sucesso conduzir a tarefa da supressão aos próprios senadores, e por fim excluiu ele mesmo outros trezentos membros, restituindo o Senado ao escol de seiscentos membros, não obstante tivesse desejado que restassem apenas trezentos. Igualmente, neste mesmo ano Augusto modificou os critérios censitários de ingresso à instituição: somente poderiam competir aqueles que detivessem um milhão de sestércios. Mais ainda, o Imperador reduziu o número de questores eleitos de quarenta para vinte - pondo fim a uma herança de Júlio César - e antecipou o ingresso à questura de trinta para vinte e cinco $\operatorname{anos}^{164}$.

As intenções são compreensíveis. Partindo dos mesmos preceitos de restauração dos valores e ideais republicanos, Augusto operou tais mudanças

\footnotetext{
${ }^{162}$ WISEMAN, 1971, p. 11.

163 SYME, 1939, p. 349-50.

${ }^{164}$ CHASTAGNOL, 1992, p. 26-7; ECK, 2007, p. 80; TALBERT, 1984, p. 55-6; TALBERT, 2008 , p. 325-6.
} 
com o intuito de realçar o prestígio do Senado, forjando uma elite dentro da própria aristocracia romana, cujo acesso formalizou uma tendência preexistente ao final da República: a garantia de lugares no Senado mediante o critério da hereditariedade ${ }^{165}$. Provavelmente Augusto também estivera ciente das complicações financeiras de boa parte das famílias remanescentes após décadas de conflitos; os mecanismos de benefício provenientes da patronagem - o que eventualmente não excluiu intenções legítimas de recuperar o prestígio destas famílias - auxiliou o Imperador a aproximar apoiadores, manter o controle sobre vários dependentes, e cercear ex-senadores indesejados ou virtuais oponentes; e talvez fora muito mais eficaz do que a austeridade imposta pela Lex lulia de adulteribus ${ }^{166}$ e pela Lex lulia de maritandibus ordinibus $^{167}$, ambas promulgadas em 17 a.C., com o intuito de reforçar o contingente e a permanência das famílias republicanas ${ }^{168}$.

De todo modo, esta ordem senatorial augustana não deteve novos preceitos constitucionais, conquanto o privilégio do acesso ao Senado tenha sido assegurado por três gerações sucessivas a filhos das ilustres famílias senatoriais de então. Mais ainda, além de assentos especiais nos jogos públicos, proibição de casamentos entre membros de ordens sociais inferiores, proibição da prostituição e adultério por suas mulheres, e da atuação no teatro, o uso do latusclavus tornou-se exclusividade dos jovens filhos destas tradicionais famílias. Ademais, um equestre só poderia deixar o angusticlavus se recebesse a dignidade senatorial por mediação do próprio Princeps no Senado $^{169}$.

\footnotetext{
${ }_{165}^{165}$ NICOLET, 2001, p. 92-3.

${ }^{166}$ Anteriormente, o costume permitia ao marido a possibilidade de vingança, mas somente após a realização de um conselho familiar (consilium propinquorum). Com esta lei, o adultério cometido pela mulher passou a ser crime: o pai da filha adúltera podia matá-la junto de seu amante, caso fossem surpreendidos na residência do marido. Este, por sua vez, era compelido a divorciar-se da esposa, e o casal adúltero deveria ser formalmente julgado em corte. Igualmente, qualquer cidadão poderia fazer a denúncia caso o marido ou o pai não o fizesse dois meses após o divórcio. A pena era banimento dos adúlteros e confiscação de um terço da propriedade da mulher, junto da perda parcial de seu dote. Cf. Berger, 1953, p. 352.

167 Em um conjunto de leis, que continha inúmeras restrições (como casamento entre homens de linhagem senatorial com mulheres libertas, cidadãos de má conduta moral e mulheres condenadas por adultério), a mais significativa foi a promoção de casamento e procriação com o intuito de evitar o declínio da moralidade e a extinção da família. Esta lei assegurava vários privilégios aos casais e parentes, e em contrapartida sanções econômicas aos celibatários e casais sem filhos. Cf. Berger, 1953, p. 553-4.

${ }_{168}$ MILLAR, 2001, p. 297; SYME, 1939, p. 443-4.

${ }^{169}$ André Chastagnol (1992, p. 42-3) afirma que, dadas as restrições impostas, a quantidade de 'senadores novos' durante o governo de Augusto foi menor que no período anterior. A maior
} 
Diante desta conjuntura, um questionamento vem à tona: qual foi o impacto de todas estas mudanças para o cotidiano do Senado? Sabemos que a enérgica recomposição do Senado não existiu sem alguns efeitos colaterais: entre os anos de 16 e 11 a.C., bem como em vários outros momentos pontuais do governo de Augusto, houve grandes dificuldades na composição do corpo institucional, especialmente entre as magistraturas iniciais. Vários senadores, mesmo em conformidade aos critérios censitários, preferiram permanecer como equestres, ou mesmo não se lançar à questura.

Além disso, outros já não desejavam se tornar tribunos ou edis ${ }^{170}$, e não raramente Augusto teve de promover equestres para estes cargos ${ }^{171}$. E como resposta, ou como mais um fator inerente a este processo, Augusto impôs maior rigidez na presença dos senadores às assembleias. Em 11 a.C., Augusto aboliu formalmente o quorum mínimo de quatrocentos senadores para a aprovação de medidas. Em 9 a.C., pela lege Julia de senatu habendo, tentou atenuar o baixo nível de comparecimento de senadores às sessões mediante a aplicação de multas, tendo estipulado também um calendário de reuniões com listas de comparecimento, criou uma "aposentadoria" e o comparecimento voluntário para os senadores de aproximadamente sessenta anos, e estabeleceu critérios de ordem para a realização das assembleias ${ }^{172}$.

Assim, concluímos que a supremacia de Augusto inevitavelmente trouxe reações diversas ao respeito como temor, relutância ou ressentimento entre membros do Senado. E pelo fato de ter sido requerido dos senadores que

parte dos italianos retornou à ordem equestre, mantendo-se como cavaleiros em virtude da manutenção dos antigos critérios censitários, ao passo que os demais homens novos mantiveram-se nas suas municipalidades. Menor ainda foi a quantidade de senadores provinciais, que só podiam se tornar senadores pelo direito de honra (ius honorum), restritos a quatro categorias: a) os provinciais que permaneceram do período republicano e que não foram limados nas reformas censitárias de Augusto; b) os provinciais cujas localidades foram assimiladas aos estatutos cívicos romanos; c) os provinciais que, independente da residência, já eram equestres.

${ }_{170}$ Cf. CHASTAGNOL, 1992, p.49-56.

171 Ronald Syme (1939, p. 372-3) afirma algo diferente. Para ele, os anos que se passaram à crise (em sua opinião supervalorizada) das eleições entre 23 e 19 a.C. mostram um contraste com os anos precedentes na presença de equestres e patrícios no Senado, e que não estivera relacionado a nenhum desejo consciente de Augusto: herdeiros das linhagens republicanas aumentaram em número, em comparação aos anos subsequentes das proscrições e eliminações decorrentes das guerras civis, o que pressionou a retomada deste contingente às magistraturas nas duas décadas seguintes. Isto explicaria uma diminuição na quantidade de membros equestres nas listas senatoriais, em comparação à década anterior, conquanto a presença equestre não tenha deixado de existir, o que demonstra uma nova ascensão de homens novos na década do falecimento de Augusto e ascensão de Tibério.

172 TALBERT, 1984, p. 56-7; 2008, p. 328-9. 
estes se ajustassem a esta quantidade de regulações e restrições, naturalmente houve uma interferência no vigor das deliberações senatoriais e na sua ideia de liberdade de expressão política ${ }^{173}$. O Princeps podia se informar pelas decisões tomadas mediante a leitura das atas do Senado (acta senatus), especialmente sobre questões externas, religiosas ou financeiras, a despeito de sua assiduidade estando em Roma ${ }^{174}$. Nesse contexto, tendo estado presente ou mediante moções (relationes) enviadas por correspondência durante suas campanhas ou viagens, as prerrogativas de Augusto concediam-lhe de toda forma o direito de interposição ou veto a quaisquer medidas deliberadas nas sessões.

A posse da primeira ou última palavra sobre um assunto ao Princeps tornou-se um hábito, não obstante Augusto esforçasse-se por agir como um senador indistinto de seus pares, inclusive muitas vezes sem se manifestar, e quase nada que o Princeps requisitasse ou apoiasse poderia ser recusado. $O$ reconhecimento de que o avanço de cada senador dependia em boa medida da aprovação do primeiro, e a compreensão de que o controle da maior parte de toda a atividade política se tornou exclusividade do Imperador foram impactantes na presença e no estímulo da ordem senatorial diante das assembleias, ou mesmo no interesse de seus membros em continuar a perseguir os pré-requisitos para ascender na carreira pública ${ }^{175}$.

Por outro lado, mesmo diante de tantas restrições, o Senado continuou sendo uma instituição de prestígio, seus cargos amplamente disputados e devidamente reconhecidos, e nenhum Imperador podia subverter a posição desta sem incorrer em um sério risco à própria vida. Uma das grandes características do Senado imperial consistiu no fato de este ter se tornado uma corte de justiça, principalmente no trato com embaixadas e representantes provinciais, respondendo juntamente com o Imperador às necessidades e vicissitudes das mesmas, bem como deliberando sobre a maior parte das questões administrativas do Estado ${ }^{176}$.

As decisões do Senado (senatus consulta) - posto que tenham se tornado cada vez mais dependentes dos pronunciamentos (orationis) do

\footnotetext{
173 TALBERT, 1984, p. 60; 2008, p. 330-1.

174 TALBERT, 1984, p. 165-171; 1984, p. 59-60.

175 CHASTAGNOL, 1992, p. 56.

176 SYME, 1939, p. 406.
} 
Princeps - adquiriram uma importância jurídica extraordinária ao período republicano ${ }^{177}$.

Embora seja verdade que, ao final do governo de Augusto, poucos se lembrassem de fato da efervescência política do período precedente, as consequências das dissensões no final do período foram significativas o bastante para que, à ruptura trazida pela ascensão de um soberano, a maior parte dos senadores (geralmente) se conformasse com um novo cenário de promoção social e política ${ }^{178}$. Isto não significa dizer que o Senado tornou-se um elemento figurativo. Em troca de sua libertas, o Senado tornou-se uma espécie de porta-voz imperial, não obstante muitos dos poderes judiciais, eleitorais e legislativos tornaram-se mais pronunciados do que outrora ${ }^{179}$. A hierarquia de magistraturas modificou-se pela intrusão de novos cargos, mas principalmente por uma mudança em sua concepção: o serviço prestado à res publica tornou-se gradualmente um serviço prestado também ao Princeps ${ }^{180}$.

De fato, houve uma restrição no poder e status individual dos senadores, principalmente dos cônsules abaixo de Augusto, mesmo este se manifestando sempre que possível como um entre os demais. No entanto, os senadores continuaram desempenhando um papel essencial para a organização política, administrativa e militar imperial. Mais ainda, no escopo de preservação das formas essenciais da República, Augusto buscou incessantemente alinhavar suas ações com a opinião e o consentimento desta ordem: consequentemente, foi preciso que Augusto e seus sucessores construíssem e reconstruíssem na prática e cotidianamente o conjunto de relações com os senadores dentro da instituição ${ }^{181}$.

\footnotetext{
${ }^{177}$ MILLAR, 2001, p. 341-50.

${ }^{178}$ ECK, 2007, p. 88.

${ }^{179}$ ROWE, 2002, p. $42-3$.

${ }^{180}$ ALFOLDY, 1989 , p. 118-9.

${ }^{181}$ BONNEFOND-CONDRY, 1995, p. 225-6; BRUNT, 1984, p. 423; TALBERT, 1984, p. 163.
} 


\subsection{2 - A ordem equestre}

Em consideração à ordem equestre, Augusto valeu-se de preceitos semelhantes aos adotados pela valorização do Senado: reafirmação dos vínculos com o prestígio do passado republicano, e o interesse de fazer deste grupo social um segmento com competência administrativa, mediante critérios de nivelamento econômico, político e moral ${ }^{182}$. O contingente da ordem equestre foi bem mais numeroso e heterogêneo do que o da ordem senatorial, e a quantia mínima requisitada para a admissão consistiu, sem alterações entre a República e o Principado, de quatrocentos mil sestércios. Contudo, a presença da primeira no âmbito da administração imperial diferenciou-se do período precedente, pois esta gradualmente forneceu mais candidatos para novos e diversos cargos ${ }^{183}$. Não podemos afirmar que a ampliação de cargos tenha seguido um planejamento específico, sendo mais provável que este crescimento fora casual e diretamente ligado aos interesses do Princeps para a resolução de demandas mais ou menos imediatas, bem como o fortalecimento de sua posição ${ }^{184}$.

Para tanto, o exercício da patronagem imperial também foi um fator presente, pois todos os cargos eram diretamente indicados pelo Imperador, como nos moldes dos cargos exteriores às tradicionais magistraturas na Cidade de Roma. Uma vez mais, a concessão destes cargos, fossem eles equestres ou senatoriais, foi um dos mais importantes mecanismos de demonstração de favorecimento e comunicação entre o Princeps e seus governados; embora seja difícil demonstrar se era necessário, além da posse da quantia mínima, receber do Imperador o direito de ser equestre, as duas maiores honras que conferiram distinção dentro desta ordem - o cavalo público (equus publicus) e a indicação para o painel do júri ${ }^{185}$ (decuriae iudicum), eram formalmente concedidas pelo Imperador ${ }^{186}$.

\footnotetext{
${ }^{182}$ NICOLET, 2001, p. 97.

183 idem, p. 99.

184 TALBERT, 2008, p. 340.

185 Grupo de jurados - possivelmente de trezentos - escolhidos para esta função. Originalmente existiram três decúrias: senadores, equestres, e tribunos do erário. $O$ primeiro grupo eliminado foi o grupo de tribunos do erário, sendo que Augusto retirou a participação do
} 
A conferência do cavalo público remete-se ao papel das centúrias equestres como destacamento da cavalaria no exército romano, desde os primórdios da República. Neste período, sua posse era uma honra avaliada durante as revisões censitárias; este costume parece ter sido mantido com Augusto, que também resgatou a celebração da parada pública anual (transvectio) dos equestres, valendo-se dessa ocasião para publicizar o reconhecimento (recognitio) e o benefício desta honra, em que a conduta do cavaleiro também era evidenciada como sinal de pertencimento à ordem ${ }^{187}$. A admissão ao painel do júri está inserida dentro do mesmo contexto histórico e é semelhante em representatividade: o recebimento desta honra - geralmente a partir dos trinta anos - dependia do Imperador, era conferido pessoalmente por ele, a ele solicitado ou então requisitado mediante a intervenção de amigos influentes ${ }^{188}$.

Ests procedimentos estiveram presentes na conferência de todos os outros cargos equestres. O primeiro grupo destes cargos consistiu do destacamento militar (militiae equestris, ou castrenses honores), tendo representado o tribunado militar, a prefeitura de uma ala ou de uma coorte. Futuros senadores também continuaram compondo as tribunas militares, mas 0 seu número tornou-se cada vez mais insuficiente diante dos mais de trezentos e sessenta postos que vagavam anualmente. Uma parte do contingente também era composta de ex-centuriões que haviam recebido status equestre por terem se tornado primipili (chefes de uma centúria) em uma ou duas legiões diferentes, e sido condecorados pelo Imperador com a quantia necessária para tornarem-se equestres ${ }^{189}$.

Deste modo e para este cargo em especial, durante o governo de Augusto já existia a prática da indicação de honesti (homens ricos e respeitáveis), tanto pelos filhos de tradicionais famílias equestres, quanto por ricos cidadãos oriundos de municipalidades alçados por recomendação pública (ex commendatione publica). A presença e a destinação destes cargos predominantemente para equestres demonstraram uma ênfase no

Senado, restringindo a composição destes apenas aos equestres, em cinco decúrias. Cf. BERGER, A. Encyclopedic Dictionary of Roman Law, 1953, p. 426.

${ }^{186}$ MILLAR, 2001, p. 275-9.

${ }_{187}$ MILLAR, 2001, p. 280-2.

188 Ídem, p. 282-3.

${ }^{189}$ D'AMATO \& RAVA, 2011, p. 11. 
restabelecimento do sentido militar que o pertencimento à ordem detivera desde a República, e a conjunção com o interesse do Imperador em fazer desta ordem um segmento preparatório para membros proeminentes das melhores famílias, bem como assegurar uma competente administração militar do Império ${ }^{190}$.

O segundo grupo de cargos concentrou-se no mencionado painel do júri, que internamente possuiu uma divisão censitária entre seus cinco grupos, estipulada a partir de duzentos mil sestércios. Além do sinal de reconhecimento e distinção inerente ao pertencimento neste corpo jurídico, muitos de seus membros continuaram sua ascensão em outros postos da carreira equestre, transitando entre Roma e as províncias, embora muitos outros exercessem as funções deste cargo em suas próprias localidades, o que também representava um enorme reconhecimento local. Por fim, no escopo deste fluxo entre centro e periferia, o terceiro grupo de cargos consistiu dos procuradores públicos. Cerca de vinte e três durante o governo de Augusto, estes últimos possivelmente se inseriram em companhias que mantivera a antiga função de arrecadação tributária dos publicani durante a República, embora a interferência do Princeps possa ter correspondido ao interesse de arrefecer as extorsões e a corrupção presente no período anterior, melhorando o afluxo de tributos para o erário público $^{191}$.

Embora saibamos das restrições impostas ao ingresso na ordem senatorial e dos esforços de Augusto para a promoção deste corpo político e seus membros, o quarto e último grupo de cargos concernentes aos membros da ordem equestre foi o próprio Senado. Evidentemente, o acesso de um equestre não era uma regra e tampouco uma obrigatoriedade, mas a possibilidade evidenciou que, possivelmente, uma das iniciativas políticas de Augusto foi encorajar estes homens a uma carreira pública caracterizada pela diligência (industria). Nesse sentido, não apenas os equestres mais experientes e com longa trajetória nos cargos respectivos a seu segmento poderiam ingressar na instituição, mas jovens de famílias equestres - fossem elas mais ou menos renomadas - também poderiam receber a dignidade de vestir o latusclavus, conquanto o direito de ser formalmente convidado para tornar-se

\footnotetext{
${ }_{190}^{19}$ NICOLET, 2001, p. 99-101; SYME, p. 384 e 396; TALBERT, 2008, p. 340-1.

${ }^{191}$ NICOLET, 2001, p. 101-3.
} 
membro do Senado (adlectio) só possua inferências a partir do governo de Cláudio ${ }^{192}$.

De todo modo, a emergência da participação equestre e sua presença em novos cargos de confiança criados pelo Princeps é uma característica particularmente importante para a compreensão da organização política no Principado ${ }^{193}$. Embora a falta de interesse nas evidências literárias seja uma condição que dificulta o traçado da criação e desenvolvimento de alguns destes cargos, é provável que entre os governos de Augusto e Tibério estes já estavam praticamente estabelecidos ${ }^{194}$. Com Augusto, temos a criação da guarda pretoriana e de sua prefeitura, inicialmente comandada por dois equestres (2 a.C.). Posteriores problemas, como um grande incêndio na Cidade de Roma, demandaram a criação da prefeitura dos vigilantes da Cidade de Roma (vigiles) (6 d.C.) composta de sete mil libertos, e a prefeitura do abastecimento de grãos (praefectura annonae) (8 d.C.), esta última após um grande racionamento que inicialmente levou Augusto a designar dois excônsules para esta tarefa, demanda que provou ser uma de permanente importância. Por último, foi constituída uma gama de postos auxiliares (adiutores) para magistraturas senatoriais e prefeituras mencionadas, que se somaram às outras procuradorias detidas pelos equestres.

Em conjunto, estes cargos evidenciaram a autoridade e influência de seus detentores, pois geralmente aqueles que os recebiam permaneciam por mais tempo e eram conferidos pessoalmente pelo Imperador ${ }^{195}$. Uma novidade, sem dúvida, estabelecida por precedentes republicanos: os principes do Senado possuíam procuradores privados que auxiliavam na administração e que eram, desde então, equestres, cuja ausência das formalidades presentes nas tradicionais magistraturas senatoriais Ihes permitia o desenvolvimento de competências e habilidades especialmente relevantes no âmbito administrativo, jurídico e financeiro ${ }^{196}$. Por exemplo, teria sido a competência (e a confiança) que pesou sobre a escolha de Gaio Cornélio Galo para a prefeitura do Egito em 30 a.C., uma vez que Augusto dividiu-se entre o interesse de restabelecer o

\footnotetext{
${ }_{192}$ NICOLET, 2001, p. 103-4.

${ }^{193}$ SYME, 1939, p. 355.

194 TALBERT, 2008, p. 340.

${ }^{195}$ NICOLET, 2001, p. 103-4; SYME, 1939, p. 357; TALBERT, 2008, p. 340-1.

${ }^{196}$ NICOLET, 2001, p. 104-5; SYME, 1939, p. 355-6.
} 
prestígio do Senado para a res publica e evitar a insurgência de rivais políticos fortalecidos pelo conhecimento e acesso à vitais recursos financeiros e militares: além de honesti, apoiadores ou amigos, dependentes diretos de uma relação entre patrono e cliente emanada do Princeps e não do Senado ${ }^{197}$, embora Sejano possa ser considerado um desvio dessa regra ${ }^{198}$.

Augusto, portanto, confirmou e reforçou um processo iniciado décadas antes do início de sua trajetória de ascensão ao poder. A promoção de indivíduos oriundos das famílias italianas que notadamente se enriqueceram durante o final da República representou uma coalizão cuja participação e influência política operou sob dois vieses principais: uma prestigiosa carreira militar e/ou a possibilidade de ingressar ao Senado ${ }^{199}$. Em meio a estas alternativas, a sua participação nos seletos grupos decisórios vinculados à confiança e preferência do Princeps foi um canal de solidariedade para sua soberania e para o fortalecimento da administração imperial.

\footnotetext{
${ }^{197}$ NICOLET, 2001, p. 106-7; TALBERT, 2008, p. 341-3.

198 SYME, 1939, p. 358; p. 384.

${ }^{199}$ Idem, p. 364-8.
} 


\subsection{3 - A corte imperial}

Estamos cientes de que Augusto se tornou o grande patrono e benfeitor da sociedade romana; os vínculos de patronagem sustentaram uma rede de interações sociopolíticas que assegurou simultaneamente o consentimento dos governados e a possibilidade de um vasto império ser administrado por seus concidadãos. Em meio a isso, sem dúvida uma das principais inovações que caracterizam a ascensão de Augusto foi a centralização do poder político da coletividade no âmbito da residência de seu soberano, e o desenvolvimento de uma corte imperial.

Neste sentido, a formação da residência dos Césares (Domus Caesaris) se deu de maneira simultaneamente original e involuntária. Sua estrutura compôs-se como um aglomerado de núcleos familiares menores, originários da vinculação consanguínea e parental entre seus membros, cuja autoridade emanou de Augusto enquanto um autêntico pater familias (chefe do domicílio) romano; enquanto princípio, a residência do Princeps foi semelhante a qualquer outro núcleo familiar aristocrático: um conjunto de residências em que os familiares se relacionavam mútua e cotidianamente, amparadas por escravos, libertos, e frequentada por amigos e clientes.

Contudo, a peculiaridade esteve relacionada ao esforço de Augusto para assegurar a transmissão do legado familiar e a forma como isto se deu. Neste sentido, a ausência de filhos homens compeliu o Princeps a construir vínculos de descendência a partir das mulheres de sua família mediante sua autoridade patriarcal, com vários arranjos matrimoniais e para o provimento de herdeiros candidatos ao seu espólio e ao êxito na transmissão do poder. A primeira frente de esforços adveio dos próprios costumes legais romanos: o Imperador valeuse da adoção, do divórcio, determinou precocemente o matrimônio de seus herdeiros entre as mulheres de sua família, bloqueou as possibilidades de filhos bastardos para que não houvesse cisão ou se potencializassem rivalidades internas, e baniu filha e netas adúlteras; tudo isto para garantir 0 que foi inicialmente transmitido de Júlio César, seu pai adotivo - o nome, o enorme patrimônio (que se ampliou ainda mais), e a grande proporção de clientes, amigos e protegidos. 
A segunda frente trouxe consigo algumas novidades: 'Augusto' e 'César' tornaram-se nome e sobrenomes exclusivos da família, perpetuados para além da dinastia Júlio-Claudiana, e tanto a residência quanto os familiares nela presentes tornaram-se referenciais da proximidade com as divindades e os bons augúrios romanos, cujos componentes simbólicos foram amplamente explorados e disseminados (especialmente pelo meio da imagem) em Roma e nas províncias ${ }^{200}$. Igualmente, esta consideração foi também reconhecida pelo Senado na medida em que os jovens príncipes da família imperial tiveram sua proeminência assegurada na carreira pública em decorrência da vinculação familiar, e de sua referência ancestral ao principal patriarca, o divino (divus) Júlio César.

A residência do Imperador e sua corte tornaram-se então o cerne deste movimento. Como instituição e termo, e ao contrário dos aspectos essenciais da família imperial, esta é estranha à República: derivado do grego aulé, aula faz referência às cortes monárquicas helenísticas, e rapidamente se estabeleceu nos escritos sobre o Principado (como em Sêneca), referindo-se ao ambiente, às pessoas e ao tipo de poder diretamente relacionado ao cotidiano do Princeps a partir do período Júlio-Claudiano ${ }^{201}$. Enquanto uma instituição social e política, que não se constituiu formalmente como o Senado, mas passou a compor significativamente boa parte das decisões sobre os rumos do Império, a corte imperial abarcou em sua própria concepção os paradoxos do regime de governo iniciado com Augusto: uma residência privada baseada nas formas e nas práticas de uma residência aristocrática republicana que se tornou o cerne decisório do Estado. O foco da atividade política transferiu-se de uma pluralidade de casas aristocráticas deslocou-se para apenas uma, inicialmente encapsulada no coração histórico e simbólico de Roma $^{202}$.

A despeito de seu funcionamento ter sido rudimentar como todo o restante da administração imperial, o desenvolvimento de suas atividades agregou formas condizentes a uma burocracia, conquanto não tivesse tido uma função específica. Em seu topo, além do Princeps, os amigos do Imperador

\footnotetext{
${ }^{200}$ CORBIER, 1994, p. 247.

201 WALLACE-HADRILL, 2008, p. 283.

202 Idem, p. 306.
} 
(amici Caesaris) representaram o topo desta estrutura alicerçada mediante o favorecimento; um grupo variado de senadores, equestres, e outros associados que detinham algum nível de acesso ao Princeps. Neste sentido, um amicus do Imperador podia esperar honores para si, e do mesmo modo auctoritas derivada de sua habilidade em influenciar decisões e assegurar benefícios para seus amigos, transcendendo a manutenção dos elementos que já durante a República asseguravam proeminência política: nascimento, diligência militar e habilidades jurídicas e oratórias ${ }^{203}$.

Em contrapartida, é difícil definir com precisão os níveis de amizade a partir de um conceito que por si só é fluido e impreciso; somente rituais inerentes ao cotidiano da própria corte podiam mensurar estes níveis de aproximação, pois embora muitos tivessem acesso à corte, poucos eram admitidos à câmara privativa do Imperador, o cubiculum principis. Por outro lado, a renunciação da amizade (renunciatio amicitiae) por parte do Princeps ou membro da família imperial demarcou a expulsão da convivência neste ambiente, e um grave prejuízo para a carreira política de qualquer senador ou equestre ${ }^{204}$.

Neste sentido, apesar de não possuírem direitos políticos formais e nem competirem por posições oficiais dentro do governo, outros agentes dentro da corte imperial também dispuseram de influência e importância, tendo sido canais de acesso político. Se por um lado a instituição senatorial teve o seu prestígio realçado mediante revisões e a constituição de uma ordem senatorial superior, e a ordem equestre tornou-se cada vez mais um grupo da qual o Princeps extraiu membros para cargos administrativos e militares, o acesso aos beneficia imperiais poderiam ser facilitados mediante a presença interlocutores dentro da residência do Imperador: príncipes, mulheres da família JúlioCláudia, libertos imperiais, e até mesmo os escravos podiam ser um atalho ou um canal de promoção e favorecimento. $E$ foram justamente estes últimos que possuíram maior destaque, competindo e posicionando-se como intermediários

${ }^{203}$ SALLER, 1982, p. 53-69; Cf. SYME, 1939, p. 374-6; p. 383-4. Syme é bem mais enfático (1939, p. 376): [...] these three categories of civic excellence were traditional, Republican and openly advertised as the justification for ennoblement.[...] There were also deeper and better reasons for political advancement in the Principate. The game of politics is played in the same arena as before; the competitors for power and wealth require the same weapons, namely amicitia, the dynastic marriage and the financial subsidy. [...].

${ }^{204}$ WALLACE-HADRILL, 2008, p. 285. 
nas disputas entre grupos políticos heterogêneos em sua composição. Todavia, estes grupos eram extremamente instáveis e tinham como objetivo primordial a entrada no círculo mais restrito de poder, e a maximização do acesso a recursos e favorecimentos a partir do Princeps embora frequentemente as disputas entre estes grupos alinhassem-se também a disputas pela sucessão imperial ${ }^{205}$.

Contudo, a corte imperial não estava atrelada à residência imperial em Roma: esta se movia com o Imperador, mesmo que nem todos os seus membros estivessem presentes, com a exceção dos locais tradicionalmente tidos como espaços públicos (o Senado) e militares (acampamentos) ${ }^{206}$. Todavia, a despeito do fato de Augusto e Tibério terem apreciado suas propriedades na Itália - principalmente na baía de Nápoles e em Capri - e se deslocado por vários e longos períodos Mediterrâneo adentro, a Cidade de Roma foi permaneceu durante quase todo o primeiro século de Principado como o principal polo da corte imperial.

A construção da residência imperial se deu em um lugar particularmente especial e que ao longo das gerações sofreu inúmeras transformações, com ampliações, justaposições e reformulações. Situada no monte Palatino, reduto de prestigiadas linhagens patrícias, foi neste bairro residencial de ilustres aristocratas como Lívio Druso, Licínio Calvo, Hortênsio, Cícero, Marco Antônio e Tibério Cláudio Nero (pai do Imperador Tibério) que Augusto - antes de ser Princeps - se estabeleceu, tendo adquirido a moradia do mencionado Licínio Calvo.

Contudo, o Princeps sacralizou sua residência imperial quando a estabeleceu no seio da Roma Quadrata, próxima da cabana de Rômulo, das escadarias de Caco e do templo à deusa Cibele, cuja lenda remetia às origens troianas da Cidade de Roma. Após a vitória no Actium, Augusto adquiriu ainda a residência de Lutácio Catulo, cujo átrio serviu como colégio em que o gramático Vérrio Flaco ensinou Gaio e Lúcio César, e que ficava próxima do templo de Apolo, guardião dos livros sibilinos - o grande receptáculo do destino de Roma - e espaço para a proteção das virgens vestais, cujo culto tornou-se também responsabilidade de Augusto, após ter se tornado supremo

\footnotetext{
${ }^{205}$ CORBIER, 1994, p. 279-82; SYME, 1939, p. 384-5; WALLACE-HADRILL, 2008, p. 302-4.

${ }^{206}$ MILLAR, 2001, p. 29-57.
} 
pontífice ${ }^{207}$. Desta maneira, o palácio (palatium) no Palatino tornou-se a principal referência desta corte, pois sua localização interseccionou o mito fundacional de Rômulo, o cotidiano da câmara senatorial e o Fórum, e o ambiente da residência (domus) imperial. Esta ambivalência arquitetônica entre o espaço público e privado também coexistiu com o sentido institucional da corte: a morada de um concidadão e simultaneamente a de um governante ${ }^{208}$.

As possessões de Augusto e seus sucessores ampliaram-se enormemente ao longo de seus governos, mas uma premissa manteve-se, principalmente entre os Imperadores Júlio-Claudianos: o quadro de funcionários, os bens móveis e imóveis passaram diretamente às mãos de cada novo Princeps, como se a herança transcendesse o aspecto familiar e tivesse se revestido como uma espécie de "patrimônio público". A residência imperial destoava das outras residências aristocráticas pelo tamanho de sua entourage, que gradualmente recebeu uma quantidade cada vez maior de funcionários hierarquicamente divididos em uma infinidade de funções e responsabilidades.

Desta maneira, em um ambiente inicialmente caracterizado por certa frugalidade - a despeito dos grandes jardins, monumentos e aposentos - a residência de Augusto e de Tibério comportava trabalhadores, escravos e serviçais que limpavam cozinhas, latrinas, carregavam lenha, mercadorias, faziam reparos, escavações ou terraplanagem. Igualmente, possuía também escravos qualificados que podiam se tornar libertos (após os trinta anos de idade), e que no paedagogium recebiam treinamento e normas de etiqueta para se comportar e servir na corte ${ }^{209}$.

Como em uma tradicional residência aristocrática republicana, o Princeps também possuía uma comitiva de amigos, clientes e protegidos que eram diariamente atendidos após as saudações matinais ou banquetes (salutationes e cena), de acordo com o grau de proximidade íntima ou formal perante o soberano ou de membros de sua comitiva ${ }^{210}$. Para tanto, na entrada do palácio havia guardiões (custodes) e porteiros (janitores); nas salas de audiência acompanhantes (velarii), funcionários responsáveis pela admissão

\footnotetext{
207 TURCAN, 1987, p. 22-3.

${ }^{208}$ WALLACE-HADRILL, 2008, p. 284-5.

209 TURCAN, 1987, p. 50-2.

${ }^{210}$ Cf. SALLER, 1987, p. 121-2; TURCAN, 1987, p. 132-40.
} 
de convidados (admissionales), liderados por um chefe (magister), subchefes (proximus), ajudantes (adjutores), e nomenclatores, que anunciavam os recepcionados ao Princeps.

Todos estes funcionários do palácio, bem como os invitatores (literalmente "aqueles que convidavam") eram importantes canais de acesso ao Imperador, sendo geralmente prestigiados ou assediados. Os cidadãos admitidos ao interior da residência imperial eram acomodados e ciceroneados por escravos de pedibus ("de pé"), e em cada aposento do palácio havia também escravos responsáveis por vigiar a mobília, assessorar ou distrair clientes e seus amigos (escravos atrienses), uma hierarquia de escravos para o apoio nos banquetes, para cuidar do mobiliário doméstico, das vestimentas e das joias imperiais. Igualmente, os condutores da liteira (lecticarii) transportavam o Imperador pelas ruas de Roma; outros escravos portavam bastões de madeira para protegê-lo, para cuidar dos veículos e cavalos; aparadores (viatores) escoltavam-no, e jovens escravos levavam correspondências e encomendas (cursores e tabelarii) pelas ruas da Cidade ${ }^{211}$.

O palácio também contava com a presença de preceptores de diversos ranques sociais que ministravam aulas - geralmente sendo remunerados pelo próprio Imperador - para jovens da aristocracia. Em meio a gramáticos e retores, filósofos e sábios também eram presenças frequentes na corte, geralmente próximos do Princeps, mulheres e dos jovens membros da família imperial. É importante enfatizar também a presença dos astrólogos, cujos conhecimentos rapidamente traziam estes homens para a intimidade $\mathrm{e}$ confiança do Imperador (podemos de antemão citar o nome de Trasilo, um dos principais confidentes de Tibério, principalmente em Capri). Além dos filósofos e astrólogos, bibliotecários, jardineiros, horticultores, paisagistas, pedreiros, carpinteiros e guardas de ronda (circitores) também foram importantes nas dependências do palácio imperial ${ }^{212}$.

E se o ambiente do palácio e da corte era caracterizado por intensa atividade social, durante os banquetes o palácio sempre contava com uma trupe de músicos (symphoniacl), tocando flautas, pratos, dançarinos, bufões (scurrae), mímicos, anões, e bufões; Tibério é tido como responsável pela

\footnotetext{
${ }^{211}$ TURCAN, 1987, p. 52-6.

212 Ídem, p. 56-9.
} 
criação do cargo de procurador dos prazeres (procurator voluptatum), cujo primeiro superintendente foi o equestre T. Cesônio Prisco. Os aposentos íntimos também contavam com escravos, e tanto o mordomo quanto os médicos possuíam uma influência considerável por estarem quase sempre próximos ao Imperador ${ }^{213}$.

Os afazeres administrativos compartilhavam do cotidiano e ambiente doméstico. A corte imperial deteve aspectos de uma burocracia, com a emergência de postos hierárquicos cujos responsáveis influenciaram no controle e difusão de acesso e informações do e para o Imperador: escravos e libertos tornaram-se correspondentes (tabellarii), libertos tornaram-se secretários (adiutoris) e notários (commentariis), e oficiais seniores secretários particulares do Imperador (conhecidos simplesmente pelo nome do cargo, ab epistulis). $\mathrm{O}$ acesso ao Princeps por membros da elite trouxe vantagens a ambos: o primeiro polarizou seus interesses na medida em que os últimos buscavam poder e influência, conquanto as tensões, disputas e intrigas dentro da corte compuseram-se como a grande contrapartida durante o Principado.

Mais importante, sem dúvida, foi a existência de um conselho (consilium) requisitado pelo Imperador para temas políticos específicos. Oriundo de matrizes republicanas, durante 0 governo de Augusto este conselho (estabelecido em algum momento entre 27 e 18 a.C.) teria consistido de dois cônsules, um pretor, um tribuno da plebe, um edil, um questor, e quinze senadores, sendo que os magistrados menores eram substituídos a cada semestre, e os cônsules e pretores anualmente. Embora possamos pressupor que este conselho se encontrava ao menos duas vezes por ano, o funcionamento e o recrutamento deste conselho geralmente fora circunstancial.

A intenção de Augusto foi contar com a opinião e o apoio de integrantes úteis, magistrados e oficiais experientes, associados de confiança, com os quais o Princeps se encontrava frequentemente para a discussão prévia de questões a serem apresentadas para deliberação ao restante do Senado ${ }^{214}$. Certamente os membros deste conselho detiveram grande influência política, embora o resultado final tenha sido um decréscimo da iniciativa dos demais membros do Senado em seus encontros, uma vez que estes podiam imaginar

\footnotetext{
${ }^{213}$ TURCAN, 1987, p. 60-2.

${ }^{214}$ GALINSKY, 1996, p. 70.
} 
que as deliberações já haviam sido previamente discutidas e arquitetadas, e da mesma forma os senadores presentes no conselho imporiam sua influência para que o desígnio do Princeps prevalecesse, fosse este o caso ${ }^{215}$.

Em contrapartida, é difícil separar este conselho de uma conjunção de amigos do Imperador que com ele mantiveram contato cotidiano, e eventualmente também se reuniam para discutir assuntos de importância no palácio no seio da corte imperial. Têm-se a impressão de que, de uma maneira geral, o conselho representou uma instância que simultaneamente acumulou funções de um comitê legislativo e um conselho privado de amici principis. Isto é compreensível, uma vez que podemos observar que o Principado trouxe uma relação bastante ambivalente entre o espaço público e privado, e é razoável concluir que boa parte dos rumos da vida pública durante o início do Principado foi decidida diante da participação destes seletos membros.

A existência regular deste conselho parece ter desaparecido depois do governo de Augusto, embora o seu impacto tenha sido permanente: o círculo mais restrito ao Imperador detivera um papel cada vez mais importante no âmbito do funcionamento administrativo desde então ${ }^{216}$. De fato, mesmo que não tenha se consolidado como um organismo formal dentro da administração imperial, a representatividade e a influência do consilium principis incidiu sobre dois princípios outrora intangíveis: a iniciativa senatorial do cônsul presidente da assembleia e a auctoritas hierárquica de seus pares. Esta modalidade de conselho acumulou os poderes executivos, legislativos e judiciários, mesmo diante de seu caráter consultivo, e sua posição extraordinária equivaleu-se às necessidades do poder decisório extraordinário do Princeps ${ }^{217}$.

Enquanto uma especificidade do que representou a corte imperial, esta manifestação política evidenciou o fato de que, em linhas gerais, Augusto e seus sucessores necessitaram de uma corte para melhor governar, e esta também necessitava de um Imperador. Embora sua existência, sua influência, bem como muitos dos acontecimentos cotidianos neste ambiente estivesse envolto em disputas, intrigas, e evidenciasse um deslocamento de poder que

${ }^{215}$ TURCAN, 1987, p. 142-5; WALLACE-HADRILL, 2008, p. 289-90.

${ }^{216}$ CROOK, 1955, 4-21; 2008, p. 129; ECK, 2007, p. 84; SYME, 1939, p. 385 e p. 407-8; TALBERT, 1984, p. 61 e 2008, p. 337; TURCAN, 1987, p. 145; WALLACE-HADRILL, 2008, p.300.

217 TURCAN, 1987, p. 146-7. 
confrontava o próprio passado republicano, a corte imperial tornou-se um sistema de poder que tendeu à perpetuação pelo resto da história do Império ${ }^{218}$.

${ }^{218}$ WALLACE-HADRILL, 2008, p. 308. 


\section{4 - A sucessão imperial: de Augusto para Tibério}

A posição política construída por Augusto não poderia ser transmitida apenas mediante seus interesses, pois isto soaria como um impulso autocrático antagônico ao governo do Império calcado na manutenção da República e de suas tradições políticas. A concretização desta intenção deveria contar com a persuasão de seus concidadãos, uma vez que a concentração de todas as prerrogativas institucionais sob sua pessoa foi um feito sem precedentes ${ }^{219}$.

O Princeps desenvolveu um esquema sucessório de transmissão dos poderes em sua família. Augusto teve apenas uma filha, Júlia, nascida em 39 a.C., e fruto de seu casamento com Escribônia, sua segunda esposa. O único familiar do sexo masculino era seu sobrinho Marco Cláudio Marcelo, concebido em 42 a.C. por sua irmã mais velha Otávia. Em 29 a.C. o primeiro já havia participado do triunfo pela vitória no Áccio ao desfilar na carruagem triunfal junto de Tibério. Quatro anos mais tarde, ambos receberam a toga viril e seguiram Augusto para uma campanha militar na Hispânia, para que fossem introduzidos à vida militar e às tropas. Após este período, com o retorno de Marcelo e Tibério para Roma, à distância Augusto ordenou o casamento entre o primeiro e Júlia - ambos tinham 14 e 17 anos, respectivamente; sem a presença do Princeps, Agripa representou o pai da noiva, o que conferiu a impressão de necessidade na realização deste enlace.

Imediatamente ao casamento, no ano de 23 a.C. Marcelo teria recebido uma concessão especial do Senado para que concorresse ao cargo de edil, e para que ascendesse ao consulado dez anos antes do prazo, figurando já como ex-pretor; Tibério recebeu apenas a questura e cinco anos de remissão para que ele disputasse os cargos de pretor e cônsul. Embora Augusto não tivesse ainda manifestado nenhum interesse explícito em confirmar Marcelo como seu provável sucessor, a este fato somaram-se algumas inquietações de membros do Senado que não viam positivamente os caminhos tomados pelo poder do Imperador. Em outros termos, havia indícios de que a concentração

${ }^{219}$ ECK, 2007, p. 149-50. 
dos poderes políticos nas mãos de Augusto, mesmo com o apoio de seus associados, não era unânime.

Desta maneira, durante este mesmo ano Marco Primo, procônsul da Macedônia, retornou para Roma sob a acusação ter iniciado espontaneamente uma guerra contra os Odrísios, tribo aliada dos romanos e, consequentemente, transposto os limites de seu poder de governador provincial. De sua parte, Primo alegou que agiu de acordo com as instruções de Augusto e de Marcelo $^{220}$, depoimento que criou um duplo mal-estar no Senado: além de Augusto ter intervido politicamente sob uma província senatorial, suas ordens não foram informadas aos membros da instituição.

Outro agravante foi o fato de que o defensor de Primo era Licínio Murena, cônsul do presente ano e genro de Mecenas; e se em princípio o Princeps se recusou a testemunhar no julgamento, posteriormente este apareceu subitamente no Senado para confirmar que não havia proferido ordem alguma e que Primo agira pelo bem do Estado. O que tornou este evento mais controverso é o fato de que, logo após a condenação de Marco Primo, Augusto descobriu uma tentativa de conspiração protagonizada por este último e o senador Fânio Cépio, conhecido pelo idealismo republicano. Não houve tempo para grandes averiguações: Cépio e Murena exilaram-se antes do julgamento, e consequentemente foram assassinados. De todo modo, o julgamento continuou e, com a defesa de Tibério, ambos foram condenados ${ }^{221}$.

Logo em seguida, Augusto adoeceu gravemente, e a este contratempo somou-se a morte de Marcelo. Nesse ínterim, ao recuperar-se, Augusto teve de lidar com rumores que sugeriam que o Princeps estava impondo uma sucessão dinástica baseada em sua vontade pessoal, bem como predeterminado em testamento a concessão do poder a Marcelo, não obstante tivesse designado todas as responsabilidades do consulado para seu colega Lúcio Cornélio Piso, e o anel de sinete para Agripa. O poder dos rumores ${ }^{222}$ teria sido tão forte que

\footnotetext{
${ }^{220}$ ECK, 2007, p. 151.

${ }^{221}$ LEVICK, 1999, p. 10-11.

${ }^{222}$ Os rumores foram uma constante desde o período republicano. Para Lawrence (1994, p. 71 2) o comportamento dos votantes durante as eleições era condicionado pelas informações disseminadas a respeito dos candidatos, fosse formal ou informalmente. De modo semelhante, elementos formais de persuasão, especialmente a salutatio e as consequentes relações entre patrono e clientes não podem ser ignoradas. A natureza desta rede de comunicações evidentemente continha inúmeras especulações e contradições que determinavam oscilações no conjunto das opiniões e atitudes da aristocracia romana. Por fim, embora o caráter das
} 
Augusto, mesmo restabelecido, se sentira obrigado a ler o testamento para o Senado para que se cessassem os questionamentos, especialmente para seus apoiadores e Agripa, um fato que evidenciou a impopularidade alcançada por esta situação ${ }^{223}$. Esta precaução é compreensível uma vez que Agripa exerceu um importantíssimo papel político e militar na administração das províncias imperiais: entre os anos de 23 a 19 a.C., este último auxiliou Augusto tanto no oriente quanto no ocidente, sobretudo na pacificação da Hispânia, e com a morte de Marcelo, seria muito difícil ignorar a influência política adquirida ao longo de todos os anos de consórcio político com Augusto. Igualmente, é plausível que Agripa também tivesse um conjunto de associados políticos que possuíam interesse em ascensão e favorecimento, caso Agripa eventualmente sucedesse Augusto.

Neste ínterim, em 18 a.C. Agripa recebeu o mesmo imperium de Augusto e o poder tribunício, tendo retornado imediatamente para as províncias. Contudo, apenas em 13 a.C., após o primeiro ter permanecido quatro anos supervisionando a província da Ásia, e o último viajado pela Hispânia e a Gália, é que ambos efetivamente se reencontraram em Roma (possivelmente uma maneira de evitar fricções políticas), com a dedicação de um monumento à paz (Ara Pacis $)^{224}$. Ainda em 23 a.C. Augusto requisitou que Agripa se divorciasse de sua esposa e que se casasse com Júlia, que com ele concebeu dois filhos ${ }^{225}$ : Gaio (20 a.C.) e Lúcio (17 a.C.), simultaneamente adotados como filhos de Augusto. Em 19 a.C. Tibério casou-se com Vipsânia, filha de Agripa, e seu irmão Druso Nero recebeu as mesmas honras políticas: em 18 a.C. e aos dezenove anos foi eleito questor, bem como autorizado a disputar o cargo de pretor e posteriormente o consulado cinco antes do prazo mínimo.

De acordo com Barbara Levick ${ }^{226}$, mediante a aproximação destes membros da família imperial, Augusto delineou um esquema sucessório que assegurava a transmissão de suas prerrogativas e o afastamento das ameaças

eleições tenha se modificado com o Principado, os rumores continuaram a ser uma importante ferramenta, agora com um novo cerne: o Princeps e a corte imperial, a partir dos quais a aristocracia e, em larga medida, o restante da população, também continuou a ser influenciada em suas opiniões e atitudes.

${ }^{223}$ ECK, 2007, p. 151; LEVICK, 1999, p. 12; SYME, 1939, p. 368.

224 SYME, 1939, p. 389.

225 Agripa Póstumo, o mais novo, nascera em 12 a.C.

226 1999, p. 16-7. 
de um golpe militar ou outra guerra civil: um sistema de justaposição de pares sucessórios com poderes equivalentes, para que não se criasse um vácuo no poder imperial, encabeçado por Augusto e Agripa, seguido por Gaio e Lúcio César, com a última opção sendo Tibério e Druso ${ }^{227}$. Provavelmente a opinião pública já tinha consciência dos interesses do Imperador em criar condições seguras para uma sucessão: Agripa possuía autoridade política suficiente para suceder a Augusto, e naturalmente tanto Gaio e Lúcio poderiam suceder Agripa, pois eles eram seus filhos naturais e uma possível garantia de não rivalidade entre os três ${ }^{228}$.

Entretanto, após vários anos cuidando da situação militar entre os partas e armênios, a morte de Agripa em 12 a.C. - em meio a um rigoroso inverno e rumo à uma campanha militar no llírico - e a minoridade de seus filhos constituíram-se como um novo revés para Augusto. Imediatamente outro rearranjo foi concebido: diante do forte interesse de Lívia Drusila, esposa de Augusto, em assegurar uma posição de proeminência para seus dois filhos anteriores ao casamento com Augusto (Druso Cláudio e Tibério), Augusto fizera com que Tibério se divorciasse de Vipsânia, sua esposa e irmã do falecido Agripa, para se casar com Júlia, após o fim do período de luto e os meses que separaram o nascimento de Póstumo Agripa, seu último filho; Druso Cláudio já era casado com Antonia, sobrinha de Augusto e também filha de Otávia ${ }^{229}$, mas também faleceu logo depois (9 a.C.) em decorrência da queda de um cavalo em campanha militar no Reno.

As mortes de Agripa e Druso obrigaram Augusto a repensar uma nova garantia para a permanência do regime. Provavelmente esta condição tenha 0 levado a promover Tibério como seu consorte político, mas desta vez sem o imediato compartilhamento dos poderes imperiais. Deste modo, Tibério exerceu consecutivamente o consulado em 8 e 7 a.C., e neste ínterim diversas vezes aclamado imperator, tendo recebido por fim um triunfo pela sujeição militar dos germanos no final de seu segundo consulado. Aparentemente, 0 recebimento do poder tribunício e do imperium naturalizariam seu nome como a alternativa evidente da sucessão: em 6 a.C., o compartilhamento dos poderes

\footnotetext{
${ }^{227}$ LEVICK, 1999, p. 17-8.

${ }^{228}$ ECK, 2007, p. 152.

${ }^{229}$ ECK, 2007, p. 153; SYME, 1939, p. 391.
} 
foi formalmente institucionalizado e ritualizado em acordo com o Senado, e o desenvolvimento de uma formalidade para a promoção política de membros da família imperial encorajado para trazer um semblante de conservadorismo republicano à experimentação política construída por Augusto ${ }^{230}$.

Contudo, novamente algo destoou do que fora planejado: Tibério abdicou formalmente da vida pública em Roma e retirou-se para Rodes, sob a alegação de desgaste pelas tarefas e o desejo de se dedicar aos estudos liberais. Sua atitude provocou um enorme mal-estar, publicamente manifestado por Augusto perante o Senado ${ }^{231}$. O evento é controverso e merece uma observação: a despeito de seu casamento com Júlia, e o infortúnio de um filho natimorto entre 10 ou 9 a.C., a ausência desta na procissão triunfal de 7 a.C. pode ter sido o indício de uma diferença pautada em questões sucessórias: como filha de Augusto e mãe dos jovens Gaio, Lúcio, e do pequeno Agripa Póstumo, Júlia talvez temesse que Tibério assumisse o poder e concedesse preferência ao seu próprio filho, em detrimento dos jovens príncipes mencionados acima. Mais ainda, a promoção pública dos jovens Césares pode ter sido um paliativo para esta insegurança, e o arrefecimento de um plausível desejo de Tibério em ser o próximo Princeps. Contudo, ao ter lido seu testamento, cuja herança iria para os remanescentes da família imperial, nenhuma ameaça de sublevação à promoção dos jovens césares aparentou estar implícita em seu exílio, e não se demonstrou de fato ${ }^{232}$.

Além disso, de acordo com Robin Seager ${ }^{233}$ o afastamento de Tibério para Rodes expôs ainda mais a fragilidade do esquema sucessório desejado por Augusto: teria sido desejo do Princeps que seu sucessor imediato tomasse conta dos futuros candidatos à soberania dentro da família imperial - enquanto estes eram jovens e inexperientes - para depois lhes conceder o poder. Entretanto, esse fluxo dependia fundamentalmente da boa vontade do sucessor, pois ele poderia simplesmente eliminar os jovens príncipes e reestruturar o processo sucessório, e não havia garantias que evitassem entre os mesmos jovens príncipes (incitados por membros de seus núcleos

\footnotetext{
230 LEVICK, 1999, p. 21-2.

${ }^{231}$ ECK, 2007, p. 153. LEVICK, 1999, p. 23

232 LEVICK, 1999, p. 25-6.

233 2004, p. 214-5.
} 
familiares) disputas até a morte pelo poder. Consequentemente, a consistência de um esquema sucessório de pares era bastante frágil.

De todo modo, ao promover seus netos e filhos adotivos, Augusto realçou os seus interesses. Em princípio, o Princeps promoveu jogos públicos em honra de Gaio e Lúcio César, os apresentou à população e os inseriu no colégio sacerdotal antes da idade mínima permitida. Em 8 a.C., Gaio César já havia acompanhado Augusto em uma campanha militar no Reno, fornecendo um bônus em nome do primeiro como forma de cativar a lealdade dos legionários - justamente quando estes estavam sob o comando de Tibério $^{234}$. No ano 6 a.C., a população teria se manifestado a favor de que o Senado assegurasse a eleição de Gaio César para o consulado, não obstante o fato de que este tinha apenas quatorze anos.

Em 5 a.C., Augusto exerceu o consulado, promovendo cerimonialmente a maioridade do jovem príncipe (o recebimento da toga virilis) e, diante da pressão popular, o Senado teria permitido que este passasse a participar de suas deliberações, tendo votado que cinco anos mais tarde ele fosse condecorado com o consulado (aos vinte anos, fato inédito na história da instituição $)^{235}$. O compromisso estabelecido criou um paralelo entre 0 condecorado princips iuventutis (príncipe da juventude equestre) e Augusto; além da inserção de Gaio e Lúcio nos juramentos de lealdade de inúmeras províncias, a trajetória construída para os príncipes era uma evidência de quem provavelmente seria o futuro Imperador ${ }^{236}$.

Aparentemente, Augusto teria assegurado duplamente a transferência do poder imperial dentro de sua própria família, mas era também necessárias a experiência militar e a popularidade dentro do exército. Assim, em 1 a.C. Gaio César foi enviado para o oriente de modo a se envolver diplomaticamente com os partas, e para coroar um novo rei na Armênia; dois anos depois adquiriu o consulado estando na Síria, e em 3 d.C. capturou a fortaleza de Artagira, sendo aclamado imperator. Lúcio fora enviado para a Hispânia, mas durante o trajeto (Marsilla) em 2 d.C. morreu subitamente. Em seguida Gaio César, no mesmo

\footnotetext{
${ }^{234}$ ECK, 2007, p. 153-5.

235 Lúcio César receberia as mesmas honras nos mesmos moldes em 2 a.C.

${ }^{236}$ ECK, 2007, p. 155-6; LEVICK, 1999, p. 24-6; SYME, 1939, p. 417-8.
} 
cerco de Artagira, fora gravemente ferido, tendo falecido em 4 d.C. na cidade de Limyra, na Lícia ${ }^{237}$.

Em meio a estas tragédias, em 2 a.C. foi revelado um escândalo de adultério envolvendo Júlia, cujo principal expoente foi lulo Antônio, filho de Marco Antônio e Fúlvia, e educado por Otávia, irmã de Augusto. A este, casado com sua filha Marcela, foi permitido o suicídio; Júlia foi banida de Roma, e aos demais $^{238}$ a morte ou exílio foram aplicados. A grande causa do adultério pode ter sido uma tentativa de aliança entre Júlia e membros de antigas famílias republicanas - vinculadas à sua mãe, Escribônia, Pompeu e Antônio - que temiam pela ascendência de Tibério e a sabotagem da sucessão de Gaio ou Lúcio César, uma vez que Augusto já estava em idade avançada ${ }^{239}$. Novamente, os desígnios sucessórios de Augusto deveriam ser reconsiderados.

Às grandes honras na Cidade de Roma seguiu-se o retorno de Tibério. Embora o adultério de Júlia tenha provocado o divórcio e o enfraquecimento dos vínculos com Augusto em 2 d.C., o desdobramento posterior ao falecimento dos dois prováveis candidatos à sucessão fizera com que o Princeps adotasse em 4 d.C. Tibério e que este último adotasse Germânico César como seu próprio filho, mesmo com a existência de Druso Cláudio, um pouco mais velho do que Germânico.

Consequentemente, em 4 d.C. Tibério recebeu as mesmas prerrogativas de autoridade que Agripa havia recebido anos antes. Agripa Póstumo, filho mais novo de Júlia com M. Agripa também fora adotado, embora as razões sejam amplamente discutíveis: provavelmente, para além do ar de inevitabilidade da escolha de Tibério, a ideia teria sido a de assegurar que o próximo Princeps fosse experiente o suficiente para lidar com os intermitentes conflitos militares na Germânia e Ilírico que se estenderam até 12 d.C., para os quais Germânico César fora imediatamente em auxílio, já em 7 d.C. ${ }^{240}$. Mais ainda, a manutenção do vínculo de consanguinidade era mais uma garantia

\footnotetext{
${ }^{237}$ ECK, 2007, p. 156.

${ }^{238}$ Semprônio Graco, tribuno da plebe no ano do escândalo, Quinto Crispino Sulpiciano, cônsul em 9 a.C., e Cipião, neto de Escribônia.

${ }_{239}^{2}$ LEVICK, 1999, p. 26-7.

${ }^{240}$ CROOK, 2008, p. 107; SEAGER, 2004, p. 36-7; p. 216.
} 
para a sucessão imperial: Germânico César era filho de Antônia, sobrinha de Augusto e, portanto, membro da família Júlia ${ }^{241}$.

Em contrapartida, Agripa Póstumo, que deveria receber o privilégio de se tornar questor e ser enviado para alguma legião como manutenção da prática de treinar os jovens príncipes nos afazeres militares, não recebeu nada. Mais ainda, entre 6 ou 7 d.C., ele foi banido de Roma, tendo permanecido um tempo em Surrento, e logo depois definitivamente ostracizado para a ilha de Planásia. Punição semelhante foi dada a Júlia Menor, ao repetir o mesmo crime de adultério de sua mãe com o senador Décimo Júnio Silano - a quem Augusto renunciou formalmente sua amizade -, e que só retornou à Roma durante o governo de Tibério ${ }^{242}$.

Implacavelmente banida pelo resto de sua vida (faleceu em 29 d.C., após anos de sustento por Lívia), Júlia Menor fora casada com Lúcio Emílio Paulo, tido por Suetônio ${ }^{243}$ como conspirador contra o governo de Augusto, e supostamente apoiado por Plautio Rufo, possível parente de Plúbio Rufo (responsável por panfletos contra o Princeps em 6 d.C). Sobre o destino de Lúcio Paulo nada se soube, mas provavelmente foi assassinado; Júlia Menor e Agripa Póstumo ainda serão futuramente relacionados a novas possibilidades de instabilidade política dentro da casa imperial logo após Tibério ascender ao poder, entre 14 e 16 d.C. ${ }^{244}$. Tanto esta conexão quanto a possível conspiração de Primo e Murena em 23 a.C. são evidências que demonstram que o governo de Augusto também deve ter sido palco de tentativas de sublevação do poder, geralmente tendo envolvido familiares e indivíduos próximos à corte imperial.

Ao final de 9 d.C., Tibério e Germânico César retornaram das rebeliões na Germânia. Para o primeiro e Augusto triunfos foram concedidos, enquanto Germânico recebeu uma insígnia triunfal, a posição de pretor, e o direito de disputar o consulado antes da idade permitida. Contudo, a derrota das legiões de Quintílio Varo obrigou Augusto a realizar um novo recrutamento, ampliando o corpo de soldados para libertos e auxiliares, e Tibério retornou para mais três anos de comando na região.

\footnotetext{
${ }^{241}$ ECK, 2007, p. 157.

242 Tácito, Anais, 3.24.

243 Vida de Augusto, 19.1.

${ }^{244}$ Cf. CROOK, 2008, p. 108-9. Ver adiante, página...
} 
No ano de 12 d.C., novamente Tibério recebeu um triunfo, mas desta vez pelo controle da ordem no llírico; tanto em 9 d.C. quanto neste anos, as aclamações de imperator para Augusto também passaram a incluir o nome do futuro Princeps; embaixadores de reinos vizinhos, conforme fizeram com Gaio e Lúcio César, prestaram deferências a Tibério, uma nítida demonstração de reconhecimento. Neste mesmo ano Germânico César recebeu o consulado, embora a situação em Roma não fosse das melhores: a uma enchente no Tibre seguiu-se a condenação de aristocrata Cássio Severo por traição, com seu banimento de Roma justificado pela publicação de escritos contra Augusto e a família imperial $^{245}$.

Em 13 d.C., os poderes de Augusto e Tibério foram renovados por mais dez anos, e o imperium de Tibério tornou-se equivalente ao do Princeps, tendo se tornado assim seu collega imperii ${ }^{246}$. Consciente de sua debilidade física, Augusto teria solicitado ao Senado a formação de um conselho de vinte senadores, com os quais discutiria assuntos cujas resoluções seriam equivalentes a decretos votados pelo Senado ${ }^{247}$. Não sabemos se este mesmo conselho permaneceu após sua morte, mas certamente não houve espanto nisso: o consilium principis e demais comitês de ilustres senadores equestres já havia atuado como suporte na corte imperial durante todo o seu governo.

Durante o verão de 14 d.C., Tibério saíra de Roma para visitar as legiões estacionadas no llírico; Augusto o acompanhara entre Benevento e Nola, na região da Campânia, e no dia 19 de Agosto lá falecera. Não temos certeza, mas provavelmente estiveram presentes Lívia e Tibério. Era o fim do governo de Augusto, e o começo da ascensão de Tibério ao poder imperial. Quando a procissão fúnebre trouxe o corpo do falecido Princeps para Roma, a cremação

\footnotetext{
245 Tácito, Anais, 1.72; Cf. CROOK, 2008, p. 110-1; ECK, 2007, p. 158.

${ }^{246}$ Suetônio, Vida de Tibério, 20-21. 1; Veléio Patérculo, 2.121.1. Dupraz (1966, p. 96-9) defende que em 23 de outubro de 12 a.C., dia em que foi realizada a cerimônia de concessão do triunfo militar a Tibério por seu sucesso contra os germanos entre 9 e 11 d.C., o futuro Princeps teria sido formalmente associado ao poder, uma vez que Germânico César tornara-se cônsul neste ano e Tibério fora publicamente recomendado ao Senado (cf. Dion Cássio, 56.26.2; Suetônio, Vida de Tibério, 20.1; Veléio Patérculo, 2.116.1; CIL I, p. 181). O argumento consiste na ênfase sobre a quinta renovação dos poderes constitucionais concedidos a Augusto, sobretudo o imperium, que efetivamente deveria ter ocorrido neste ano, e não o fora pelo fato de Tibério estar ausente até então, mesmo com a determinação do triunfo publicamente divulgada. Consequentemente, a despeito da celebração triunfal ter ocorrido somente em outubro, o ano civil de 12 d.C (765) já teria marcado a associação de Tibério ao Principado.

${ }^{247}$ Dion Cássio, 56.28.2-3.
} 
foi realizada próximo ao mausoléu criado em 32 a.C., antes até de sua vitória no Áccio. O Senado proclamou Augusto deus (divus), e a construção de um templo para seu culto próximo ao fórum; igualmente foi criado um novo sacerdócio, o sodales Augustales, para celebrar seu culto, composto por Tibério, Germânico César, e um seleto grupo de senadores. Como divindade do panteão romano, o culto a Augusto tornou-se parte do próprio culto pela segurança e estabilidade do Estado.

A despeito das experimentações de cada sucessor, todos eles estiveram vinculados à sua memória, e a designação Augusto passou a compor formalmente o nome dos Imperadores; tendo iniciado o Principado como restabelecimento da República, uma parte significativa dos resultados obtidos pelas graduais transformações políticas de seu governo continuou (não sem contínuo desenvolvimento) sob seus sucessores ${ }^{248}$.

${ }^{248}$ CROOK, 2008, p. 111-2; ECK, 2007, p. 158-63. 


\section{CAPÍTULO II - O PRINCIPADO DE TIBÉRIO: OS ANOS EM ROMA}

\section{1 - Tibério Princeps: a família imperial no cerne do poder}

Augusto faleceu no dia 19 de Agosto de 14 d.C., aos setenta e cinco anos de Idade, após quarenta e cinco anos de promoção e soberania no posto de restaurador da República e Princeps. O quase meio século de separação entre o final dos conflitos civis e militares e a ascensão de Tibério representou um gradual deslocamento das relações de poder no âmbito da aristocracia senatorial e equestre em Roma, cujos membros se depararam a partir de então com a necessidade de se relacionarem com um líder e os vários núcleos presentes dentro da residência imperial como maneira fundamental de buscar favorecimento e ascensão na carreira pública, que paradoxalmente se manteve republicana em essência.

Durante seu governo, Augusto exerceu poderes extraordinários concedidos formalmente pelo Senado e o povo, e deteve a primazia no controle militar das legiões estacionadas nas províncias imperiais. Após a sua morte, a história política do Principado (aqui em seu período inicial de experimentação) se tornou também uma narrativa sobre o Imperador, grupos e indivíduos que, sobretudo pela proximidade a ele, desempenharam um papel relevante nos assuntos públicos dentro da Cidade de Roma e nas províncias ao redor do Império. Os remanescentes das antigas famílias republicanas só continuaram ativos na medida em que se vincularam ao Princeps e seus associados, e tanto estes quanto homens novos puderam compreender que o favorecimento tornou-se um componente fundamental para o acesso a qualquer porção de prestígio ou poder.

As mais importantes decisões políticas ganharam um novo foro - o consilium - que privativamente deliberava sobre quais deveriam ser as formas de encaminhamento dos assuntos mais relevantes dentro da nova ordem política, conquanto o Senado não deixasse de exercer - e ver realçada - sua função deliberativa, cada vez mais administrativa, e associada a uma espécie de corte consultiva de justiça. Todavia, a mais importante atribuição do 
Imperador consequentemente foi o exercício da gratia, e a manutenção de uma rede de compromisso, solidariedades e consenso, como o grande patrono imperial; um papel calcado na reciprocidade de seus governados, e inserido dentro de um pressuposto político essencial: permanecer sob o comando de todo o processo político, maximizar seu prestígio, e assegurar a decisão sobre a quem recairia todo o poder após sua morte.

O requisito básico para assegurar esta ordem consistiu na hegemonia da casa imperial e, por conseguinte, sobre a guarda pretoriana, magistrados, o Senado e o povo de Roma, o exército e as províncias ${ }^{249}$. Como sucessor de Augusto, o primeiro passo político de Tibério (provavelmente preconcebido após sua adoção em 4 d.C. e intermediado pelo seu predecessor) foi assegurar-se de que ele era o novo pater familias, para em seguida se firmar como o novo pater patriae. No que diz respeito à família imperial, o Princeps promoveu a continuidade da domus Caesaris como representante da liderança da sociedade romana, onde as mulheres exerceram influência perante a opinião pública, e os jovens descendentes do sexo masculino foram sistematicamente promovidos como potenciais sucessores imperiais.

Este esquema iniciou-se com Cláudio Marcelo, Tibério e Druso Nero em 29 a.C., Gaio e Lúcio César até 2 d.C., e depois novamente Tibério - também como guardião - de Germânico César e Druso Cláudio, até o ano de 23 d.C., quando Druso Cláudio faleceu. Uma vez que esta organização era essencialmente frágil e instável, os anos posteriores do governo de Tibério viram o desmantelamento deste esquema, diante da conturbada relação deste Princeps com Nero e Druso, príncipes remanescentes do núcleo familiar de Germânico César e sua viúva Agripina, sistematicamente eliminados a partir da interferência do prefeito do pretório Lúcio Aélio Sejano, que de sua parte provavelmente desejou redirecionar a linha sucessória de modo que pudesse, provavelmente com a tutela de Tibério Gemelo (único e jovem remanescente da família de Druso Cláudio), assegurar para si uma posição política jamais conquistada por um equestre. Por fim, Gaio César representou uma quebra definitiva nesse padrão (pois assassinaria Tibério Gemelo logo após assumir o

${ }^{249}$ WIEDEMANN, 2008, p. 199-200. 
poder), e em 41 d.C., Cláudio foi conduzido ao poder pela guarda pretoriana, e não mais por um desígnio do Imperador precedente.

Embora Cláudio tenha adotado Nero (resultado de seu casamento com Agripina Menor) como alternativa à pouca idade de seu filho Britânico, a morte deste Princeps e a idade prematura com a qual Nero assumiu o poder, sob a proteção de sua mãe, Sêneca e Afrânio Burro, já não representavam mais a possibilidade de se haver dois príncipes na linha sucessória: a despeito das causas obscuras da morte de Britânico antes de assumir a toga viril, naturalmente Nero e Agripina o observavam como um futuro rival ao comando; durante o governo do último César Júlio-Claudiano, os desígnios sucessórios para a preservação do poder na Domus Caesaris já não eram mais os mesmos.

Entretanto, mesmo diante das transformações nesse contexto, reconhecidos como generais e modelos para a juventude aristocrática mediante a reciprocidade dos elementos concernentes ao culto imperial, os potenciais sucessores do Principado encarnavam virtudes que transmitiam a possibilidade da manutenção do regime político inaugurado por Augusto e a estabilidade no mundo romano. Mais do que apenas a figura do Imperador, a casa imperial associou-se às tradicionais instituições republicanas e passou a figurar como o cerne do recebimento das honras e da difusão da noção de consenso ao restante dos concidadãos romanos, tanto na Cidade de Roma, quanto em suas províncias ${ }^{250}$. E é pela observação deste aspecto que devemos iniciar nossa análise sobre o governo de Tibério, e como se desdobraram os acontecimentos que influenciaram sua conduta política e por último o seu afastamento para a ilha de Capri.

${ }^{250}$ ROWE, 2002, p. 1-2. 


\subsection{1 - 0 assassinato de Agripa Póstumo}

Com a adoção de Tibério em 4 d.C., a última década de governo de Augusto representou o esforço deste Princeps para assegurar a continuidade da posição política por ele adquirida, e dentro de sua própria família. Tácito sintetizou $^{251}$ a empreitada de Augusto para assegurar que seus poderes fossem transmitidos mediante um processo de sucessão dinástica como "dominação" (dominatio) ${ }^{252}$ : inicialmente o Princeps promoveu seu sobrinho Marcelo mediante o pontificado e o cargo de edil, assim como Agripa que, a despeito de seu status, teria sido de grande préstimo como soldado e um consorte no êxito do Imperador; Agripa foi cônsul por duas vezes e, após a morte de Marcelo, tornou-se genro de Augusto por seu casamento com Júlia.

Os filhos mais velhos deste casamento, Gaio e Lúcio César, foram adotados - tendo sido eleitos príncipes da juventude, e com um grande desejo de que atingissem o consulado - conquanto à morte de Agripa seguiu-se à de seus próprios filhos: Lúcio César quando estava rumo à Hispânia e Gaio César na Armênia; com a morte de seu irmão Druso, restou apenas Tibério; evidentemente, o poder deveria permanecer dentro da casa imperial, e maiores garantias deveriam ser asseguradas para tanto: Tibério foi adotado, recebeu 0 mesmo imperium e o poder tribunício de Augusto e, pelo estímulo deste último,

\footnotetext{
${ }^{251}$ Tácito, Anais, 1.3.1-3.

252 É importante considerarmos o significado que o termo dominatio apresenta na leitura da obra de Tácito, especialmente pela influência de sua percepção política sobre o Principado ter representado o escopo de uma tradição política da qual este autor, bem como autores posteriores ao primeiro, e provavelmente suas fontes literárias utilizadas se valeram para a reconstrução da res gestae política dos Imperadores Julio-Claudianos. Neste sentido, Herbert W. Benario (1964, p. 103) nos aponta que, se principatus e libertas podem ser termos associáveis, a perversão da libertas é a dominatio, o governo de um único soberano sem limitações de poder ou desejo. A potentia, denominação de exercício do poder normalmente assegurada pelo controle das armas ou influência ilícita, ganha terreno na narrativa à medida que a libertas de todos é convertida em dominatio por uma cupido potentiae (vontade de poder). Desta forma, se o Princeps é um homem indigno, o governo é condicionado a ser uma dominatio, para o qual não há solução que não a morte deste Princeps e sua sucessão por um homem melhor. Entretanto, a percepção de que o Principado pode ser uma boa forma de governo pela existência de uma liberdade, tal qual foi possível numa era dourada da República, assegurada por um soberano que não seja ávido de dominação, por si só não é suficiente para justificar a preocupação do autor e de seu período com o problema do Principado: existe uma percepção ressentida da inevitabilidade desta forma de governo, e da incapacidade da aristocracia senatorial do início do Império em retomar à antiga instituição republicana, bem como outra possibilidade de comando.
} 
foi bem posicionado perante as legiões ${ }^{253}$. Augusto ainda estabeleceu Germânico César como o comandante de oito legiões às margens do Reno, e determinara que este fosse adotado como filho por Tibério, a despeito de seu jovem filho Druso ${ }^{254}$.

Todavia, um dos membros da família imperial não foi ajustado no quadro de pares de candidatos à sucessão e à preservação do poder dentro da família Júlio-Cláudia: Agripa Póstumo. Filho caçula de Júlia Augusta e Agripa, adotado junto de Tibério, este também era um César e, pelo menos em princípio, deveria constar como possibilidade dentro do esquema sucessório. Contudo, não foi exatamente isto o que aconteceu e, para Tácito ${ }^{255}$, Lívia Drusilla teria sido responsável por convencer Augusto a deportá-lo para a ilha de Planásia: inocente, apesar de destemperado e fisicamente perigoso. Dito de outro modo, Veléio Patérculo aponta ${ }^{256}$ que antes mesmo de sua adoção conjunta com Tibério, o filho caçula do casamento entre Agripa e Júlia Augusta já demonstrava sua indocilidade e, consequentemente, era razão de descontentamento por parte de Augusto: pouco tempo depois tivera o merecido fim que sua loucura reservara.

Por sua vez, Suetônio ${ }^{257}$ atesta que a partir do momento em que Tibério foi adotado, nada que pudesse alçar seu prestígio foi ignorado, especialmente após a deserção e o banimento de Agripa, o que confirmava que as expectativas de sucessão correspondiam apenas ao futuro Princeps. De todo modo, embora Tibério e Agripa Póstumo tivessem sido adotados por Augusto no mesmo dia e durante a mesma cerimônia, a adoção de Tibério teve como justificativa o bem da res publica ${ }^{258}$; e o destino dos dois prováveis sucessores se mostraram bem diferentes nos anos seguintes.

Deste modo, Tácito afirma ${ }^{259}$ que, em meio à idade avançada de Augusto, às discussões esparsas sobre a liberdade de outrora, e sobre o receio de conflitos, os olhares de todos naquele momento concentravam-se de fato para aquele que sucederia o poder; em meio a tanta controvérsia, Agripa

\footnotetext{
${ }^{253}$ Tácito, Anais, 1.3.3.

${ }^{254}$ Tácito, Anais, 1.3.4-5.

255 Idem, 1.3.4.

256 2.112.7.

${ }^{257}$ Vida de Tibério, 15.2.

${ }^{258}$ Suetônio, Vida de Tibério, 21.3; Veléio Patérculo, 2.104.1.

${ }^{259}$ Anais, 1.4.1-3.
} 
Póstumo estava isolado e era inferior em idade e experiência, ao passo que Tibério - mesmo com a tradicional arrogância da família Cláudia - era maduro e militarmente experiente, sempre presente dentro da casa imperial, condecorado com triunfos e consulados ${ }^{260}$.

Diante deste quadro, o Principado de Tibério teria começado em meio a uma série de incertezas que emanaram do círculo mais restrito deste poder constituído, a própria família imperial. Em seus últimos dias de vida, Augusto resolveu acompanhar Tibério, que rumava para o llírico com o intuito de reforçar a ordem militar na região, e aproveitou o ensejo para prestigiar jogos em sua homenagem em Neápoles. Contudo, após separar-se de Tibério em Benevento e ter seguido para Nola, começou a sentir-se mal. Uma vez que os últimos tempos tinham lhe demonstrado a piora de sua condição física, o malestar do Princeps teria justificado a ordem de imediato regresso enviada por Lívia a Tibério; este encontrara sua mãe e seu pai adotivo rodeados de uma forte escolta, e talvez tenha chegado a tempo de receber as últimas orientações e despedir-se de Augusto ${ }^{261}$. Um comunicado fora imediatamente enviado para todas as províncias e legiões informando a morte deste e a ascensão de Tibério; igualmente a guarda pretoriana recebeu a senha que informava quem agora estava sob o controle do poder militar ${ }^{262}$.

Veleio Patérculo introduz o relato sobre a morte de Augusto com uma inferência sobre o temor (metus) que circundava Roma ${ }^{263}$; Germânico César acabara de retornar para a Panônia, e as fronteiras viveram momentos de insegurança até dois anos antes. Em contrapartida, incertezas também pairavam na corte imperial, pois Tácito afirma ${ }^{264}$ que o assassinato de Agripa Póstumo foi o primeiro crime do Principado de Tibério: surpreendido por um centurião, ele teria sido à duras penas eliminado na ilha Planásia, onde estava exilado desde 7 d.C., e a ordem teria advindo de um manuscrito lavrado por Augusto determinando que se realizasse 0 crime tão logo falecesse. A execução talvez tenha ocorrido antes do anúncio da morte do Princeps ${ }^{265}$, ou talvez tudo tivesse sido engendrado por Lívia (e Tibério) ou diante da própria

\footnotetext{
${ }^{260}$ Cf. Suetônio, Vida de Tibério, 16-21; Veléio Patérculo, 2.104-22.

261 Tácito, Anais, 1.5.3-4; Veléio Patérculo, 2.123.1-2.

262 Dion Cássio, 58.2.1; Tácito, Anais, 1.5.4, 1.7.5.

263 Veléio Patérculo, 2.123.1.

264 Anais, 1.6.1.

265 Dion Cássio, 57.3.5; Suetônio, Vida de Tibério, 22; Tácito, Anais, 1.6.1.
} 
iniciativa do encarregado, com a participação de um importante amigo, Salústio Crispo $^{266}$.

Uma explicação para este assassinato poderia ser buscada em meses anteriores a este crime. Certo de seu destino, o Princeps teria sido acompanhado por uma comitiva com o intuito de visitar Agripa Póstumo: lágrimas e promessas de perdão teriam permeado o encontro, e talvez isso representasse algum tipo de reabilitação política, pois seu neto também poderia ser um candidato à sucessão imperial ${ }^{267}$. Todavia, a notícia teria chegado rapidamente aos ouvidos de Lívia pelas palavras de Márcia, esposa do consular Fábio Máximo, que acompanhava Augusto nesta viagem; após o relato ter chegado a Tibério, Fábio Máximo falecera misteriosamente pouco depois, e seu funeral foi marcado pelas lamentações de culpa de sua esposa $^{268}$. Igualmente nebulosa teria sido a forma como a confirmação do assassinato chegou a Tibério.

Ao ouvir do centurião (ou tribuno) encarregado que tudo tinha sido feito conforme o demandado, Tibério se mostrou em princípio surpreso, depois irritado, pois não teria ordenado nada: o fato deveria ser relatado ao Senado ${ }^{269}$. Tal atitude teria gerado pânico em Salústio Crispo: como um possível acusado, este suplicou a Lívia que convencesse Tibério de que os segredos da casa imperial (arcana domus) não fossem publicizados ${ }^{270}$; as versões se espalharam, e o esquecimento encarregou-se para ninguém fosse por fim punido $^{271}$.

Esta atmosfera de rumores, intrigas e segredos dentro da corte imperial suscitou um enorme $\mathrm{e}$ inconclusivo debate sobre a responsabilidade assassinato de Agripa Póstumo, cujo crime foi atribuído a Augusto, a Tibério, a Lívia e Tibério, a Lívia e Salústio Crispo, a Tibério e Salústio Crispo, apenas a Salústio, ou apenas a Lívia, a um impulso revolucionário do centurião responsável pela guarda de Agripa, bem como apontara inclusive que a morte deste último resultou de causas naturais ${ }^{272}$. Em verdade, as evidências sobre

\footnotetext{
${ }^{266}$ Dion Cássio, 57. 3. 6; Tácito, Anais, 1.6.2-3.

${ }^{267}$ Tácito, Anais, 1.5.1.

${ }^{268}$ Idem, 1.5.2.

${ }^{269}$ Dion Cássio, 57.3.5; Suetônio, Vida de Tibério, 22; Tácito, Anais, 1.6.3.

270 Tácito, Anais, 1.6.3.

271 Dion Cássio, 57.3.6; Suetônio, Vida de Tibério, 22.

${ }^{272}$ DETWEILER, 1970, p. 294-5.
} 
este evento não nos permitirão avançar para além das conjecturas, pois a própria documentação nos oferece uma posição vacilante a este respeito.

Mas teria sido Agripa Póstumo realmente um candidato plausível para ascender ao lugar de Augusto? Certamente não, embora não tenha deixado de representar uma ameaça política, caso tivesse conseguido angariar efetivamente apoiadores à sua causa. Nesse sentido, as preocupações de Augusto e de Lívia não teriam sido injustificadas: a gravidade dos conflitos militares na Germânia e a preocupação com a saúde de Tibério nesse contexto é uma forma mais interessante de se interpretar as correspondências trocadas entre este último e Augusto, e que são expostas por Suetônio ${ }^{273}$; uma preocupação que teria envolvido não somente os assuntos militares nas fronteiras, mas uma eventual celeuma dinástica caso Augusto fosse uma vez mais privado de um iminente sucessor 274 .

Possivelmente tenha existido, em algum momento entre os anos posteriores à adoção de Tibério e o falecimento de Augusto, algum tipo de posicionamento contrário a Tibério ou à família Cláudia, bem como uma contrapartida favorável à família Júlia, cujo núcleo legítimo de intenções pudesse ter sido Agripa Póstumo. Em contrapartida, se existiu algum plano de apoiadores deste último para reabilitá-lo após o falecimento de Augusto, não podemos afirmar, ainda que sua eliminação demonstre claramente que ele era um elemento político indesejável ${ }^{275}$.

Por outro lado, acreditamos ser improvável que Agripa Póstumo pudesse ser readmitido à família imperial por vontade de Augusto. Uma vez que não era permitida a readoção de um filho que recebesse emancipação (abdicatio) ou fosse oferecido para a adoção de outrem, a deserção e o banimento de Agripa Póstumo teriam se constituído como um emaranhado de impedimentos jurídicos para seu regresso, o que só poderia ser revertido caso um pedido pessoal de sua parte tivesse sido encaminhado ao Senado, o que dependeria certamente da influência do próprio Augusto, e que de todo modo não ocorreu $^{276}$.

\footnotetext{
${ }^{273}$ Vida de Tibério, 21.7.

${ }^{274}$ Cf. BIRCH, 1981, p. 160-1, cujo argumento seria valido para a interpretação de outras passagens também em Vida de Augusto, 51. 3; 71. 2; 71. 3; 76. 2.

${ }^{275}$ PAPPANO, 1941, p. 41.

${ }^{276}$ LEVICK, 1972, p. 696-7; Cf. WIEDEMANN, 2008, p. 201.
} 
Já a presença de Salústio Crispo ressaltou uma importante consideração sobre o destaque dado ao assassinato de Agripa Póstumo e sua correlação com o começo do governo de Tibério: a inevitabilidade da centralização do poder e da condução da política imperial dentro do ambiente constituído por Augusto, a corte imperial.

Embora este só tenha aparecido no relato de Tácito, a personagem em si caracterizou a existência dos conselheiros e associados políticos do Imperador e da família imperial, muitos deles sem vinculações administrativas ou magistraturas, mas que desempenharam importantes papéis, ou estiveram presentes em questões sigilosas perenes ao cotidiano da residência do Imperador. Seu envolvimento ${ }^{277}$ teria exemplificado a imersão do Principado em um ambiente de rumores políticos e intrigas internas, e a natureza confidencial da corte uma característica fundamental do Principado ${ }^{278}$. Acreditamos que o assassinato de Agripa Póstumo fez parte de uma série de medidas tomadas para assegurar a transmissão do poder de Augusto para Tibério, e para evitar quaisquer intempéries políticas durante este processo. $O$ que fica claro é que a execução constituiu-se como a primeira atitude do novo pater da família imperial para garantir o controle da residência e corte imperial ${ }^{279}$. Não saberemos responder quem empreendeu a ação, mas podemos concluir que foi premeditada, e seu resultado indissociável da ascensão de Tibério ao poder.

Mesmo isolado politicamente por Augusto, Agripa Póstumo pode ter sido visto como um referencial político daqueles que não estavam interessados na centralização do poder imperial nas mãos do Imperador, ou melhor, no seio da família Cláudia, e sua libertação uma possibilidade de reabilitação não só para

${ }^{277}$ Salústio Crispo demonstra a relação entre a proximidade dos círculos mais restritos da família imperial e a possibilidade - bem como os riscos - da influência adquirida: este provavelmente estivera envolvido na eliminação de Clemens, ex-escravo de Agripa Póstumo e que se travestira da pessoa do dono dois anos depois (Tácito, Anais, 2.39), apenas quatro anos teriam decorrido da última menção a seu envolvimento político com importantes questões imperiais e seu falecimento. Herbert W. Benario afirma (1962, p. 321-2) que o declínio de sua influência no poder político parece algo ilusório, pois Salústio Crispo teria nascido em 55 a.C., e tendo como fato seu envolvimento em 16 d.C. Mais ainda, a profícua carreira pública de Caio Salústio Crispo Passieno, seu filho adotivo, cujo pai natural teria sido L. Passieno Rufo, cônsul ordinarius em 4 a.C., teria sido também um indício da manutenção de seu favorecimento político, pois o primeiro fora ainda apontado como cônsul suffectus em 27 d.C. e ordinarius em 44 d.C., membro do círculo imperial de Gaio César, procônsul da província da Ásia em 42-3 d.C., marido de Domícia, tia de Nero, e depois também de Agripina, que o envenenara.

${ }^{278}$ KEHOE, 1985, p. $248-254$.

${ }^{279}$ WIEDEMANN, 2008, p. 202. 
si, mas para sua mãe Júlia Augusta, e por fim uma tentativa de recondução do poder para este núcleo familiar dentro da residência imperial; isto poderia ter provocado uma instabilidade política indesejável fosse para Augusto, Lívia ou Tibério, principalmente se levarmos em consideração os relatos sobre a presença do ex-escravo de Agripa Póstumo, Clemens, e uma possível conspiração protagonizada pelo senador Marco Escribônio Libo Druso, algum tempo depois do assassinato do primeiro.

Sobre essa questão, Suetônio afirma ${ }^{280}$ que Tibério hesitara em assumir imediatamente o Principado por alguns temores que o faziam assumir que estava segurando um lobo pelas orelhas: o aparecimento de Clemens, a existência de um golpe sendo tramado por Libo, e por fim os motins nas fronteiras. Ao passo que os motins foram rapidamente desmembrados e Clemens capturado, somente dois anos depois Libo Druso fora finalmente descoberto e conduzido ao Senado, por temer que seu poder ainda não estivesse assegurado ${ }^{281}$. Conquanto não possamos crer que Tibério realmente hesitara sobre o poder, e muito menos que ele esperara dois anos em incertezas, outros detalhes demonstram que, de certo modo, havia de fato uma preocupação política entre a família imperial que não se extinguira imediatamente após a morte de Agripa Póstumo.

Tácito narra ${ }^{282}$ que Libo fora compelido por seu amigo íntimo e senador Fírmio Cato a consultar astrólogos sobre sua sorte: jovem e deslumbrado, a presença de imagens de seu bisavô Pompeu, sua tia-avó Escribônia (segunda esposa de Augusto), e de outros membros da casa imperial em sua residência teriam feito com que ele começasse a agir de forma extremamente extravagante e aspirações ao poder; um pretexto para uma denúncia privada a ser feita mediante Flaco Vesculário, um equestre associado de Tibério, conquanto sem sucesso ${ }^{283}$. Se este encontro ocorreu antes de Libo Druso ser indicado para o cargo de pretor, e se seus desígnios (sandices ou não) já eram de conhecimento do Princeps antes da ascensão, não podemos dizer ${ }^{284}$. De todo modo, durante o ano 15 d.C., Libo Druso parece ter frequentado

\footnotetext{
${ }^{280}$ Vida de Tibério, 25.1.

${ }^{281}$ Suetônio, Vida de Tibério, 25.1-2.

${ }^{282}$ Anais, 2.27.1-2.

${ }^{283}$ Tácito, Anais, 2.28.1.

${ }^{284}$ LEVICK, 1999, p. 149; SEAGER, 2004, p. 75.
} 
normalmente a residência imperial - não obstante Tibério estivesse sempre acompanhado, e em um sacrifício o último tivesse usado uma faca cega.

Somente no ano seguinte, já como pretor, Libo Druso foi levado ao Senado sob a acusação de Lúcio Fulcínio Trio, após a delação de um adivinho chamado Júnio, ao qual Libo solicitara que consultasse os espíritos dos mortos $^{285}$. A acusação foi levada a sério no Senado. Libo solicitou o apoio de mulheres da aristocracia e a defesa de vários senadores sem sucesso, mesmo acompanhado de seu irmão e cônsul no ano anterior, Lúcio Escribônio Libo, cujo apoio em tese poderia ter sido importante. Além de Fulcínio Trio e Fírmio Cato, Fonteio Agripa e Víbio Sereno também participaram da acusação: Libo havia consultado os astrólogos para saber se sua riqueza era suficiente para cobrir o caminho entre Roma e Brundísio com moedas, e nomes de membros da família imperial e senadores estavam manuscritos e assinalados com sinais suspeitos. Para confirmar a acusação, os escravos de Libo foram comprados pelo Senado e torturados até a confissão ${ }^{286}$.

Feito isto, Libo solicitou um prazo de dois dias para se defender: após um apelo infrutífero de Públio Sulpício Quirino a Tibério, Libo cometeu suicídio; o julgamento prosseguiu, o último foi condenado, e seus bens divididos entre os acusadores ${ }^{287}$. Além disso, todos os senadores tiveram o cargo de pretor assegurado, bem como senadores associados de Tibério ${ }^{288}$ avançaram moções no Senado para que os descendentes e familiares de Libo não pudessem mais usar o sobrenome 'Druso', sacrifícios fossem feitos a Júpiter, Marte e Concórdia, e que 13 de Setembro (dia de seu suicídio) fosse feriado ${ }^{289}$.

\footnotetext{
${ }^{285}$ Suetônio, Vida de Tibério, 25.2; Tácito, Anais, 2.28.2-3.

${ }^{286}$ A utilização da tortura de escravos e a promoção dos acusadores com honras políticas são práticas mencionadas também por Dion Cássio (57.19.2), embora a menção esteja deslocada do recorte temporal referente à condenação de Libo Druso - o trecho citado corresponde ao exame dos eventos consulares do ano 21 d.C.. Neste sentido, Dion Cássio afirma que aqueles que haviam acusado ou testemunhado contra outros compartilharam dos bens do condenado $e$ receberam adicionalmente tanto ofícios quanto honras. A passagem é importante por também ressaltar o problemático precedente estabelecido durante o governo de Tibério: a confissão dos escravos era um artifício que praticamente referendava a culpabilidade de acusados por traição (LEVICK, 1999, p. 146).

${ }^{287}$ Tácito, Anais, 2.30-2.

${ }^{288}$ Marco Aurélio Cota Messalino (cônsul em 20 d.C.), L. Pompônio Flaco (cônsul designado); C. Lentulo (cônsul em 14 a.C.); L. Planco (cônsul em 13 d.C.), C. Asínio Galo (cônsul em 8 a.C.); M. Pápio Mutílio (cônsul suffectus em 9 d.C.); L. Aprônio (cônsul suffectus em 8 d.C.). Cf. LEVICK, 1999, p. 149-50.

${ }^{289}$ EJ 52; Tácito, Anais, 2.32; Veléio Patérculo, 2.129.2.
} 
Embora as acusações nos pareçam superficialmente um tanto pueris, a ameaça que Libo Druso pode ter oferecido a Tibério teria se relacionado às conexões dentro da própria família imperial: Escribônia poderia estar relacionada às mulheres as quais Libo pedira apoio e inserida em uma trama conspiratória, uma vez que ela acompanhara Júlia Augusta durante o exílio e, dentro de um contexto um pouco mais amplo, provavelmente a simultaneidade com o aparecimento de Clemens não tivesse sido mera coincidência ${ }^{290}$ : indícios de movimentação contrária à hegemonia de Tibério poderiam estar sendo mantidos dentro da família imperial.

Com relação à Clemens, este teria tentado sem sucesso resgatar Agripa Póstumo da ilha de Planásia com o intuito de conduzi-lo para as legiões ao norte, mas devido ao atraso da embarcação, não teria chegado a tempo; todavia, este teria roubado as cinzas do falecido, se escondido na Etrúria, deixado seu cabelo e barba crescerem, até o momento em que começara a fazer aparições furtivas nas cidades italianas (e talvez da Gália, nicho da clientela da família Júlia e, portanto, aliados potenciais para uma sublevação) dizendo-se o próprio Agripa, e conquistando seguidores.

Ciente do caso, Tibério preferiu encaminhar novamente a resolução para a discrição de Salústio Crispo: rapidamente Clemens fora trazido ao palácio, inquirido e executado sem maiores alardes, pois muitos indivíduos - tanto dentro da residência imperial - quanto senadores e equestres, teriam the fornecido apoio e recursos ${ }^{291}$. Uma vez mais, observamos como o acesso ao favorecimento e ao poder não estiveram única e exclusivamente nas mãos do Princeps, mas presentes a demais membros da família do Imperador dentro da residência imperial.

Nesse ínterim, Barbara Levick aponta $^{292}$ coerentemente para a possibilidade de sérios transtornos políticos decorrentes de uma aliança entre Libo Druso e Clemens (utilizado como Agripa), como forma de obter suporte para um núcleo de poder constituído a partir de Escribônia, Júlia Menor (ainda exilada), Marco Emílio Lépido (primo de Libo, cujo pai fora amigo de Lúcio Emílio Paulo, esposa de Júlia e executado por conspiração contra Augusto), e

\footnotetext{
${ }^{290}$ LEVICK, 1999, p. $150-1$.

291 Dion Cássio, 57.16; Suetônio, Vida de Tibério, 25.1-2; Tácito, Anais, 2.39-40;

${ }^{292}$ Cf. 1999, p. 151-2.
} 
Quinto Cecílio Metelo Silano (suporte de Tibério e Germânico), cujo irmão Décimo Júnio Silano estava exilado por ser amante de Júlia. Enquanto Silano e Lépido eram governadores da Síria e Hispânia (e sob o controle de fortes legiões), a elevação do falso Agripa poderia conduzir o suporte de outros membros do Senado a uma revolução, caso Clemens tivesse obtido maiores apoios na Gália, teoricamente próximo das legiões estacionadas no Danúbio e o Reno, e sob o controle de Germânico.

A nosso ver, a relação entre estes núcleos é possível e a concatenação entre estes dois eventos trouxe certa insegurança dentro da corte imperial para além do ano de 14 d.C., mas enquanto um outsider de todo o processo sucessório, dificilmente Agripa Póstumo e o núcleo constituído a partir de Escribônia, Júlia Augusta e Júlia Menor teriam sustentado a posição do primeiro diante da popularidade de Germânico César e todos os precedentes criados para que ele naturalmente sucedesse o Principado, conforme as instruções legadas por Augusto. Em outras palavras, neste cenário observamos que os interesses em disputa eram diversos, e que diante destes múltiplos elementos em potencial conflito, a tarefa de Tibério em sustentar as estruturas do poder imperial em experimentação pelos próximos anos não seriam menos simples em sua própria residência do que o seria perante 0 Senado. Os indícios para a compreensão das motivações que o levariam dez anos mais tarde a se afastar de Roma já apareciam no início de seu governo. 


\subsection{2 - Germânico César e Druso Cláudio}

Casado com Agripina, a filha mais velha do matrimônio entre Júlia Augusta e Agripa, e filho de Druso Cláudio Nero (irmão de Tibério) com Antônia (irmã de Marco Antônio), Germânico e sua prole tornaram-se as grandes expectativas de Augusto para que o poder continuasse nas mãos da família imperial e retornasse para o seio da família Júlia: ao ser adotado por Tibério, imediatamente após a própria adoção deste por Augusto em 4 d.C., o primeiro exerceria a responsabilidade de cuidar e assegurar posteriormente que Germânico pudesse ascender ao comando imperial, pois este último ainda era novo para tanto e Tibério mais experiente. Augusto provavelmente tinha consciência de que não viveria o suficiente para ver Germânico Princeps, mas antes de morrer, é possível que, em sucessão ao apontamento deste último como cônsul em 12 a.C., tivesse deixado instruções para os próximos passos políticos do jovem príncipe, de modo semelhante ao que fizera com Gaio e Lúcio César, uma década antes ${ }^{293}$.

Por conseguinte, em meio aos primeiros encontros entre Tibério e o Senado, uma das medidas aprovadas por consenso já em 14 d.C. teria sido a concessão do imperium proconsular para Germânico; sob o controle das legiões no llírico, legados foram imediatamente enviados para the comunicar a prerrogativa recebida e o falecimento de Augusto $^{294}$. A concessão do imperium proconsular representou a continuidade da estratégia estabelecida por Augusto: diante de um possível enfraquecimento da sucessão dinástica pela morte de um Princeps, seu subordinado - superior em poderes aos demais senadores - estaria em plenas condições de assumir o controle; caso não houvesse uma morte, o mesmo controle viria a seu tempo (três anos depois, Germânico recebeu o triunfo pela Germânia, em 18 tornou-se cônsul pela segunda vez, e recebera o imperium maius) ${ }^{295}$.

Entretanto, nesse ínterim, dois motins militares irromperam nas fronteiras, respectivamente as legiões estacionadas na Panônia e no llírico.

\footnotetext{
${ }^{293}$ SEAGER, 2004, p. 32.

${ }^{294}$ Tácito, Anais, 1.14.3.

${ }^{295}$ LEVICK, 1999, p. 148.
} 
Para Tácito ${ }^{296}$, a ocorrência dos motins derivou exclusivamente do fato de que a mudança de Princeps foi um artifício para a desordem e as recompensas de uma guerra civil ${ }^{297}$; as legiões VIII, IX e XV estavam acampadas desde o verão sob o comando de Júnio Bleso, cônsul suffectus em 10 d.C. e tio do Lúcio Aélio Sejano, novo prefeito da guarda pretoriana, e que, ao ser informado do falecimento de Augusto e da ascensão de Tibério, suspendera as atividades dos exércitos em decorrência do período de iustitium (paralisação das atividades públicas decorrentes de um importante fato): este recesso teria sido o ponto de partida para que alguns elementos entre as legiões começassem a planejar o tumulto ${ }^{298}$.

Os motins não começaram do nada: muitos dos legionários presentes nestas legiões já haviam ultrapassado o período regular de serviço militar proposto por Augusto, e com a dureza dos conflitos que se sucederam nos últimos dez anos de governo deste Princeps, os sintomas desta fadiga apenas encontraram um momento conveniente para vir à tona. Em meio ao tumulto, um soldado chamado Percênio teria reunido dissidentes ao anoitecer e persuadido seus colegas sobre a incerteza da melhoria de suas condições de trabalho após a morte de Augusto, ponto de partida para o motim que culminou com a tentativa de assassinato de Júnio Bleso e a tortura de seus escravos ${ }^{299}$. Fundamentalmente os soldados demandavam a antecipação do término do serviço militar de vinte para dezesseis anos, aumento do soldo para um denário por dia (metade do recebido pelos membros da guarda pretoriana), e imediato

\footnotetext{
${ }^{296}$ Anais, 1.16.1; Dion Cássio, 57.4.1.

${ }^{297} \mathrm{~A}$ menção sobre uma guerra civil sugere que o Principado sempre esteve em constante perigo de perecer pelos mesmos motivos pelos quais se consolidou. Aqui, a ressalva se faz necessária pelo fato de a obra taciteana tecer sempre relações entre o futuro imediato e 0 passado mais recente pelo qual o Principado floresceu (KRAUS; WOODMAN, 1997, p. 97). Paralelamente, ao passo que observamos na literatura de Tácito uma preocupação em explicar a consolidação do poder imperial valendo-se em parte da insinceridade ou da hipocrisia como vício inerente aos soberanos no Principado, constata-se também a difícil percepção de que a realidade do poder no estado concentrava-se inevitavelmente nas mãos daquele que controlava o exército. A detenção de um supremo comando militar dificilmente se permitiria ser contraposta à vontade de partilha daqueles que não possuíssem essa essencial prerrogativa de poder. Igualmente, para Von Fritz (1954, p. 88-9), ainda em Tácito, a conciliação deste fato com a tentativa de se manter os sentimentos daqueles que ainda estavam ligados à memória da tradição republicana constituiu-se como a grande mentira do Principado, que em certa medida deve ter acompanhado a tradição política da qual este autor se valera. Portanto, independentemente do caráter individual do Imperador, hipócrita em maior ou menor escala, a composição do poder seria mantida mesmo diante do inevitável ressentimento da aristocracia. ${ }^{298}$ Tácito, Anais, 1.16.2.

${ }^{299}$ Dion Cássio, 57.4.1.
} 
recebimento das recompensas, ou caso contrário sublevariam a província e marchariam sobre Roma ${ }^{300}$.

Júnio Bleso propôs então o envio de seu filho homônimo (na ocasião tribuno militar) e legado a Tibério e ao Senado, com o pretexto de que, caso a dispensa militar requerida fosse aprovada, as demais demandas seriam posteriormente atendidas. Contudo, esta alternativa não arrefecu plenamente os ânimos dos soldados ${ }^{301}$, e a notícia da revolta em Roma levou Tibério a enviar Druso Cláudio para o centro do motim sem instruções específicas. Com ele, seguiram um corpo de senadores, duas coortes pretorianas com um contingente reforçado de soldados, além da adição de uma considerável parte da cavalaria pretoriana e os principais auxiliares germanos, bem como o prefeito da guarda pretoriana, Lúcio Aélio Sejano, que na ocasião dividiu o ofício junto de seu pai, Seio Estrabão ${ }^{302}$.

A recepção com a chegada de Druso não foi exatamente calorosa; nem mesmo a leitura de uma correspondência de Tibério exaltando os anos em que esteve sob o comando destas legiões ${ }^{303}$ apaziguou a situação: a justificativa do luto por Augusto e o adiamento da discussão das demandas dos soldados para uma futura assembleia com o Senado, bem como a impossibilidade de resoluções imediatas pela autoridade de Druso em dialogo com Clemens, centurião incumbido de apresentar as demandas ao príncipe ${ }^{304}$, aumentou a insatisfação no acampamento.

Com isto, os legionários montaram um cerco ao redor de Druso e sua comitiva para evitar uma tentativa de fuga, com a promessa de intensificar a violência ${ }^{305}$. Curiosamente, a tragédia parece ter sido evitada pelo acaso com a ocorrência de um eclipse que, pela interpretação dos soldados, foi compreendido como um mau agouro decorrente da insatisfação dos deuses com a revolta; o esmorecimento dos ânimos destes homens fizera com que

\footnotetext{
${ }^{300}$ Dion Cássio, 57.4.2-3; Veléio Patérculo, 2.125.1-2.

${ }^{301}$ Dion Cássio, 57.4.3; Tácito, Anais, 1.19.3.

302 Tácito, Anais, 1.24.1-2.

${ }^{303}$ As campanhas na Panônia entre os anos de 12 a 9 a.C. e 6 a 9 d.C (Veléio Patérculo, História Romana, II. 96-98; 104-114).

${ }^{304}$ Tácito, Anais, 1.24-6.2.

${ }^{305}$ Dion Cássio, 57.4.4. Tácito, Anais, 1.28.1.
} 
uma vez mais fosse permitido o despacho de enviados para Tibério: junto de Júnio Bleso, os equestres Lúcio Apônio e Justo Catônio ${ }^{306}$.

Parece-nos que Druso e sua comitiva resolveram aproveitar ao máximo a oportunidade oferecida pelo eclipse: entre esperar o retorno da comitiva e medidas mais drásticas, optou-se pelo segundo caminho. Percênio e Vibulêno, os principais instigadores do motim, foram executados, e junto deles todos os demais que cooperaram com a revolta, aniquilados por centuriões interessados em provar sua lealdade a Druso, e por membros da guarda pretoriana ${ }^{307}$. Se oferecermos crédito às fontes, a resolução para o conflito é delineada de modo a demonstrar a afamada severidade do jovem príncipe ${ }^{308}$ e como esta característica por fim determinou o fim motim na Panônia; após uma grande tempestade de inverno e o arrefecimento dos ânimos, Druso voltara a Roma sem esperar pelo retorno da comitiva anteriormente enviada ${ }^{309}$.

Diante dos relatos podemos concluir que as revoltas generalizadas entre as legiões representaram sua precária situação em decorrência da política militar de Augusto nos últimos anos de governo, especialmente a dificuldade de recrutamento para o longo conflito na Germânia entre 5 e 12 d.C.. A derrota das legiões comandadas por Quintílio Varo em 9 d.C. também foi outro agravante por ter levado Augusto a oportunizar ingresso de elementos da plebe romana pouco acostumados à disciplina militar, como forma de preencher os contingentes necessários para manter as guarnições nas fronteiras ${ }^{310}$. Por fim, após quase meio século de lealdade sob o comando de um imperator, a ascensão de outro que participara ativamente das campanhas militares na região e era conhecido dos soldados pode ter se mostrado uma boa oportunidade para reivindicar melhorias e acertos de contas ${ }^{311}$.

Todavia, a rebelião que simultaneamente ocorreu no llírico foi bem mais grave, e a presença de Germânico César inicialmente não se mostrou um facilitador nem para a resolução do impasse, e nem mesmo para apaziguar a dita desconfiança que Tibério nutria por seu enteado. Como um componente adicional à complexidade da transmissão dos poderes (contabilizado o

\footnotetext{
${ }^{306}$ Dion Cássio, 57.4.4; Tácito, Anais, 1.28-9.1.

${ }^{307}$ Tácito, Anais, 1.29.4-30.1.

308 Tácito, Anais, 1.29.4; Veléio Patérculo, 2.125.4.

${ }^{309}$ Dion Cássio, 57.4.5; Tácito, Anais, 1.30.2-5.

${ }^{310}$ SEAGER, 2004, p. 48, 52.

${ }^{311}$ WIEDEMANN, 2008, p. 207.
} 
assassinato de Agripa Póstumo), o posicionamento do príncipe diante das perturbações, e principalmente a relação que sua esposa Agripina manteve com os legionários e a população na região da Gália certamente contribuiu para que o Princeps observasse o tumulto como mais um foco de tensão no âmbito da estratégia de sucessão imperial.

De antemão, podemos afirmar que a incerteza provocada pela distância e a velocidade dos meios de comunicação pode ter sido um gatilho. Em Roma, Tibério não sabia ainda qual havia sido o desfecho do motim na Panônia quando chegaram notícias da perturbação no llírico; a população teria começado a repreender o Princeps, e existia desconfiança quanto à legitimidade de Druso e Germânico frente aos sediciosos ${ }^{312}$. Ao mesmo tempo, Tibério teria ficado em dúvida sobre as prováveis consequências de atender pessoalmente um foco de descontentamento em detrimento de outro, bem como sobre deixar os recentes afazeres políticos em prol de outra campanha militar; por fim, a despeito de ter preparado provisões para tanto, optou por permanecer em Roma ${ }^{313}$.

A nosso ver, parece-nos que foi a melhor opção. De acordo com Dion Cássio $^{314}$, esta postura de Tibério motivou-se em parte pela desconfiança em relação à situação das legiões nas fronteiras e pela presença de Germânico em meio a elas; o Princeps tivera a fidelidade das legiões italianas assegurada por Augusto, mas poderia inclusive retirar-se da vida pública caso uma revolta irrompesse. Duvidamos sinceramente desta possibilidade: o exílio em Rodes demonstrou que seu isolamento não o deixara a salvo, principalmente quando sua autoridade expirou. De todo modo, Suetônio complementa ${ }^{315}$ que as tropas tinham demandas semelhantes às panonianas, mas recusavam-se a reconhecer Tibério como Princeps, pressionando Germânico para que arrebatasse (capessendam) a res publica, a despeito de sua recusa: a contenção de Germânico teria sido uma forma de protelar sua ascensão ao Principado ${ }^{316}$.

\footnotetext{
${ }^{312}$ Tácito, Anais, 1.46.1-2.

${ }^{313}$ Idem, 1.47.1-3.

${ }^{314}$ 57.3.1-2. De modo semelhante: Tácito, Anais, 1.31.1.

${ }^{315}$ Vida de Tibério, 25.2.

${ }^{316}$ Dion Cássio, 57.5.1; Suetônio, Vida de Tibério, 25.3.
} 
Tácito afirma ${ }^{317}$ que havia esperanças em meio aos legionários de que Germânico não se contentasse com o imperium inferior ao de Tibério, e mesmo Veléio Patérculo confirma ${ }^{318}$ que os primeiros desejavam alguém que se atrevesse a se tornar um novo líder, em uma nova ordem. Nada disso aconteceu, mas o fato de estas possibilidades terem sido mencionadas pelas quatro principais narrativas sobre $\mathrm{o}$ assunto é significativo, tenham elas convergido de fontes semelhantes ou não: estas mostram que Germânico permaneceu leal a Tibério em todas as instâncias do motim, mas ambos tinham posturas políticas diferentes: Germânico era muito mais afeito à opinião pública, e meio as legiões ele estava acompanhado de Agripina, que de acordo com Tácito $^{319}$ era ávida de popularidade e bastante ciente de sua descendência de Augusto ${ }^{320}$.

Quanto ao motim, às margens do Reno havia duas divisões do exército compostas por quatro legiões: II, XIII, XIV e XVI sob o comando de C. Sílio Cecina, cônsul em 13 d.C. e; I, V, XX e XXI sob o comando de A. Cecina Severo, cônsul suffectus em 1 a.C.. A insurreição iniciou-se no acampamento de Sílio Cecina, composto em sua maioria por libertos de origem germânica ${ }^{321}$, logo tendo se alastrado para os demais soldados e para as outras legiões. Diante das reclamações dos soldados, frente às duras marcas exibidas pelos anos de combate, e pela ineficácia em rememorar os feitos de Augusto e Tibério, e a despeito de oferecer lealdade para que Germânico usurpasse o imperium, este último recusou-se a compactuar com os legionários, o que culminou com uma dramática tentativa de ameaçar seu suicídio, fato que não foi o suficiente para desmobilizar a revolta ${ }^{322}$.

Outro artifício foi então utilizado: Germânico e sua comitiva propuseram a composição de uma correspondência em nome de Tibério oferecendo a dispensa militar a todos que já haviam excedido os vinte anos de serviço, redução para dezesseis anos de serviço para os demais, e o pagamento em dobro dos benefícios, especialmente para aqueles recrutados por Augusto nos

\footnotetext{
317 Anais, 1.31.1.

318 2.125.1-2.

319 Anais, 1.40 .1

${ }^{320}$ Cf. SEAGER, 2004, p. 53-4.

321 Tácito, Anais, 1.31.4.

322 Dion Cássio, 57.5.2; Tácito, Anais, 1.34-35.5.
} 
anos anteriores ${ }^{323}$. Todavia, outro imprevisto ocorreu: a chegada de uma comitiva senatorial trouxe desconfiança aos legionários, e ao mesmo tempo estes descobriram que a correspondência de Tibério era uma farsa. Acuado, Germânico se viu forçado a pagar suas promessas do próprio bolso, ao passo que os senadores quase foram esmagados pelos soldados, em uma situação de insegurança que compeliu a fuga de Agripina (grávida) e o jovem Gaio César, e de outras esposas do acampamento ${ }^{324}$.

Por outro lado, esta situação motivou uma reviravolta: a comoção pela saída das mulheres e crianças para um abrigo em meio aos tréviros, uma tribo estrangeira, fez com Germânico se valesse da situação para incutir o arrependimento às tropas, que haviam sido outrora leais a Tibério e à família imperial. Após um longo discurso ${ }^{325}$, os legionários teriam implorado pelo retorno de Agripina, Gaio César e do restante dos refugiados e, a partir de então, espontaneamente aprisionado e executado os principais opositores, de modo que os demais foram julgados no próprio acampamento ${ }^{326}$. Contudo, ainda havia focos de conflito: Germânico tivera dificuldades de apaziguar os ânimos dos soldados da V e XXI legiões (as primeiras a se amotinar), fato que levara Sílio Cecina a notificar o primeiro sobre a ameaça de uma guerra aberta entre os remanescentes e as legiões restabelecidas. Consequentemente, a investida de Germânico provocou enormes baixas entre os revoltosos ${ }^{327}$.

Por fim, temeroso de uma nova amotinação, Germânico ordenou a invasão da região como forma de oferecer provisões e trabalho para os soldados: sob o pretexto de recuperar os estandartes perdidos com a derrota sob o comando de Quintílio Varo anos antes, as tropas procederam à aniquilação e pilhagem das tribos da região até o começo do inverno ${ }^{328}$.

Primeiramente, ele enfrentou a tribo dos chatii, resgatou Segesto, general germânico aliado dos romanos do cativeiro de seu genro Armínio, bem como moveu quatro legiões para a região de Amísia por meio de uma manobra naval. Em seguida, Germânico adentrou a floresta dos Teutoburgos e enterrou solenemente os restos mortais dos legionários de Quintílio Varo. Todavia, o

\footnotetext{
${ }^{323}$ Dion Cássio, 57.5.3-4; Tácito, Anais, 1.36.3.

${ }^{324}$ Dion Cássio, 57.5.5-7; Tácito, Anais, 1.37-41.4.

${ }^{325}$ Tácito, Anais, 1.43-4.

${ }^{326}$ Dion Cássio, 57.5.7; Tácito, Anais, 1.44.1.

${ }^{327}$ Tácito, Anais, 1.45-9.

${ }^{328}$ Dion Cássio, 57.6.1; Tácito, Anais, 1.50-1.
} 
forte inverno e uma sucessão de enchentes the infligiram grandes perdas em homens e provisões, ao mesmo tempo em que as legiões sob o comando de Sílio Cecina foram gravemente atacadas por Armínio ${ }^{329}$.

O saldo das rebeliões militares durante o primeiro e segundo anos do governo de Tibério culminou na desconfiança entre o Princeps e o comportamento de Germânico César perante o exército ${ }^{330}$. Tácito afirma ${ }^{331}$ que Tibério ficara satisfeito com a supressão do motim, apesar de desconfiado em relação à popularidade conquistada por Germânico com a concessão de dinheiro e antecipação das dispensas. A despeito de todos os benefícios terem sido conferidos em nome do Imperador, provavelmente não seria um exagero o complemento de Dion Cássio ${ }^{332}$ sobre a possibilidade de este último ter chances de deter o poder imperial, pelo grande apoio de seus clientes e dos romanos: as mensagens de agradecimento teriam sublinhado o temor da conquista da empatia das legiões, pois as ações de lealdade do jovem príncipe perante os soldados teriam encoberto as reais ambições deste e de Agripina ${ }^{333}$.

De todo modo, tanto Germânico quanto Druso Cláudio receberam as mesmas aclamações de Tibério perante o Senado (se desconsiderarmos a insinuação de Tácito de que a moderação ao saudar Druso fora mais convincente ${ }^{334}$ ), e C. Sílio Cecina, A. Cecina Severo e L. Aprônio receberam insígnias triunfais ${ }^{335}$. Contudo, em 15 d.C. Tibério não cumprira a promessa de dispensar os soldados, sob a alegação de que isto comprometeria os compromissos militares, e tampouco aboliu a taxa para o aerarium militare instituída por Augusto ${ }^{336}$.

\footnotetext{
${ }^{329}$ Cf. Tácito, Anais, 1.55-71.

${ }^{330}$ Cf. MALLOCH, 2004, 198-210. Para ele, a existência de uma disparidade na extensão e na profundidade do enfoque dado por Tácito, Dion Cássio e Suetônio ao motim no llírico (e principalmente o papel de Agripina, Gaio César, e as tentativas de convencimento empregadas por Germânico sobre os soldados) não nos impedem de perceber a existência de uma fonte comum empregada pelos três autores. É especialmente interessante a conclusão pelo autor apontada de que Tácito apresentou Germânico como um general de caráter falho, embora inocente - mediante a representação oferecida por Dion Cássio (57.5.7) - pois a mortandade de soldados no final do conflito deveu-se à própria iniciativa deles em vingar os estandartes perdidos com a derrota de Quintílio Varo em 9 d.C.

${ }^{331}$ Anais, I. 52.1.

${ }^{332}$ 57.6.2.

${ }^{333}$ Dion Cássio, 57.6.2-3.

${ }^{334}$ Anais, 1.52.3.

335 Dion Cássio, 57.6.4-5; Tácito, Anais, 1.52.1-3.

${ }^{336}$ Tácito, Anais, 1.78.1; Cf. SEAGER, 2004, p. 61.
} 
Em 16 d.C. Germânico preparou uma grande invasão naval ao atravessar os lagos ao norte da região, mas o confronto com Armínio não resultou em vitória, fato agravado por uma nova perda de parte de sua frota no retorno pela mesma região ${ }^{337}$. Durante todas as campanhas contra os germanos, Germânico conseguiu grandes avanços, mas também retrocessos, tendo falhado em constituir condições para a permanência na região e a continuidade da guerra; este fato teria justificado a ordem de retorno por parte de Tibério ${ }^{338}$.

Uma vez tendo conseguido restaurar o prestígio das legiões romanas pela recuperação dos estandartes perdidos com a derrota das tropas sob Varo, uma tentativa de conquistar mais do que a estabilidade na fronteira do Rio Reno poderia ter representado desconsideração pelas instruções de Augusto para não expandir o território imperial, debilitando desnecessariamente o erário com as despesas de guerra. Em verdade, ameaças externas permaneceriam tênues, devido à dissensão militar entre as próprias tribos germânicas, que culminaram tanto com o exílio de Marubóduo em 19 e o assassinato de Armínio em 21 d.C. ${ }^{339}$.

Para nossos interesses, o envio de Germânico para o Oriente em 18 foi um evento muito mais significativo, principalmente pelo trágico desfecho com sua morte e as implicações dentro da família imperial. Após ter assumido o consulado com Tibério e recebido o imperium maius (e por consequência mais autoridade do que os demais governadores de províncias e legados imperiais), houve uma clara compreensão de que Germânico César estaria a caminho da sucessão imperial; seu envio para a província da Síria seria uma importante experiência militar e administrativa neste sentido: ao passo que Tibério era velho para a empreitada, Druso Cláudio era novo demais. Em contrapartida, a razão da escolha parece complexa: ao mesmo tempo em que há plausibilidade em honrar o futuro herdeiro com importantes missões, provavelmente houve também uma intenção de distanciar Germânico das legiões do llírico ${ }^{340}$.

\footnotetext{
${ }^{337}$ Cf. Tácito, Anais, 2.5-26.

${ }^{338}$ SCULLARD, 2011, p. 229; WIEDEMANN, 2008, p. 210.

339 ALSTON, 1998, p. 27; SCULLARD, 2011, p. 229; SEAGER, 2004, p. 74.

340 Tácito, Anais, 2.48. Sobre as razões para o envio de Germânico, e os limites da interpretação taciteana, Cf. ALSTON, 1998, p. 27; SCULLARD, 2011, p. 229; SEAGER, 2004, p. 81-2; WIEDEMANN, 2008, p. 210.
} 
Junto de Germânico, Tibério apontou Gneio Calpúrnio Pison como governador da província. Importante membro de linhagem republicana e de grande experiência administrativa e militar, Pison havia sido cônsul com Tibério em 7 a.C., e sua esposa Plancina era amiga de Lívia. O pretexto para o envio de Germânico teria sido o vácuo no trono dos partas ${ }^{341}$ : em 15 d.C., Vonones, rei conduzido por Augusto, foi expulso por Artabano, tendo feito com que 0 primeiro se refugiasse na Armênia ${ }^{342}$.

Nesta região, pelo trono também se encontrar vazio logo ao início de 16 d.C., Vonones se pronunciou como candidato, condição recusada tanto por Tibério quanto por Artabano. Em meio a isto, o até então governador da Síria, Quinto Cecílio Metelo Silano, achou melhor evitar um conflito com os partas e manteve Vonones de comum acordo sob sua guarda ${ }^{343}$. Germânico iniciou sua jornada ao Oriente com uma visita à Druso Cláudio na Dalmácia - talvez como uma forma de atenuar rumores sobre diferenças entre ambos ${ }^{344}$; assumiu 0 consulado oficialmente em Nicópolis (cidade construída por Augusto como dedicação à vitória no Áccio), e de lá seguiu para Atenas, onde Agripina concebeu Júlia Livila, imediatamente deificada pelos atenienses ${ }^{345}$. Paralelamente, Pison e Plancina já haviam rumado para Síria, e após sua chegada, o primeiro teria distribuído donativos para os soldados e os liberado do serviço militar, deixando-os ociosos, uma indicação clara de manipulação das tropas, enquanto Plancina portava-se como se fosse Agripina ${ }^{346}$.

Paralelamente, Germânico diplomaticamente coroou Zenão (posteriormente Artaxias) como novo rei da Armênia, enquanto a Capadócia foi entregue a um equestre e a Comagênia (posteriormente associada à Síria) ficou sob a autoridade de $\mathrm{Q}$. Serveu ${ }^{347}$. O problema tornou-se evidente após Pison e seu filho Marco terem se recusado a enviar um destacamento de

${ }^{341}$ Ao mesmo tempo, o reino da Capadócia tornara-se uma província imperial com a morte de Arquelau; os reinos da Comagênia e da Cilícia haviam perdido seus lideres, e a despeito dos interesses da nobreza de submissão ao Imperador, a população desejava a manutenção da dinastia. Por último, as províncias da Síria e da Judéia reivindicavam redução nos tributos. Cf. Tácito, Anais, 2.42.

${ }^{342}$ Tácito, Anais, 2.1-2.

${ }^{343}$ Idem, 2.3-4.

${ }^{344}$ Ibidem, Anais, 2.43.

${ }^{345}$ Ibidem, Anais, 2.53. EJ 95.

346 Tácito, Anais, 2.55. Sobre a ausência de uma reação de Tibério a uma possível demonstração de usurpação das legiões, de acordo com a descrição deste autor, Cf. SEAGER, 2004, p. 85.

${ }^{347}$ Dion Cássio, 57.17.7; Tácito, Anais, 2.55-6. 
legionários para a Armênia; quando Germânico e o primeiro se encontraram primeiramente entre associados no acampamento de inverno da $X$ legião em Antioquia, e posteriormente em banquetes na corte - eles se tornaram inimigos declarados $^{348}$. Simultaneamente, a despeito de Germânico ter removido Vonones da Armênia como forma de não provocar maiores descontentamentos entre Artabano e os partas, Pison teria se tornado favorável ao retorno de Vonones ao trono, possivelmente como afronta à Germânico ${ }^{349}$.

Entretanto, foi a iniciativa de visitar o Egito em meio a esta situação que pareceu ter agravado a relação entre Germânico César e Tibério. Tácito afirma ${ }^{350}$ que Germânico quisera conhecer as antiguidades do local, embora o pretexto fosse o de checar a situação da província: diante de um forte racionamento que estava ocorrendo na região, o príncipe reduziu os custos dos produtos pela abertura dos armazéns, apaziguando os ânimos da população local. Nesse ínterim, Germânico também teria agraciado a população ao andar pelas ruas sem escolta, acessível, de pés descalços e com trajes gregos, à moda de Cipião Africano. Todavia, Tibério teria the enviado uma correspondência reprovando a adoção destes costumes, e principalmente o fato de ter violado o preceito augustano de adentrar a província sem o consentimento do Princeps ${ }^{351}$. Por outro lado, um fragmento do papiro oxyrhincus $^{352}$ demonstra que Germânico estivera no Egito oficialmente, como parte das medidas para a organização da administração nas províncias do Oriente romano, e que realmente parece ter sido calorosamente recepcionado. Este fato é perceptível no reverso de outro edito veiculado durante o mesmo período, em que Germânico formalmente refuta qualquer aproximação entre suas determinações e inferências divinas, determinando que apenas Tibério e Lívia pudessem receber tais deferências ${ }^{353}$.

Aparentemente, a impressão de mal-entendido teria gerado uma reação menos acrimoniosa por parte do Princeps se a relação entre ambos estivesse em melhores termos: demonstrações de tamanha popularidade na província do Egito, especialmente entre os alexandrinos, ainda saudosos de seu avô Marco

\footnotetext{
348 Tácito, Anais, 2.57.

${ }^{349}$ Idem, 2.58.

${ }^{350}$ Anais, 2.59.1; ver também Suetônio, Vida de Tibério, 52.

${ }^{351}$ Tácito, Anais, 2.59.2-3.

${ }^{352}$ Vol. XXV 2435.9 apud BRAUND, 1985, p. 190, n 557.

${ }^{353}$ EJ 320 (b) apud BRAUND, 1985, p. 191, n 558.
} 
Antônio, bem como aproximações prematuras entre Germânico e Agripina como centro da família imperial poderiam ter sido considerados como indício de pressa ou anseio de usurpação do Principado, um componente adicional para a desconfiança nutrida por Tibério em relação ao seu enteado e sua nora desde 14 d.C. ${ }^{354}$.

Contudo, tendo recebido ou não reprimendas do Princeps ainda no Egito, Germânico retornou para a Síria, onde se deparou com uma reversão de todas as suas instruções pela manutenção da ordem entre as legiões ali estacionadas. Após um novo desacordo entre o príncipe e Gneio Pison, logo em seguida foram espalhadas notícias de seu adoecimento, celebradas manifestadamente pelo último. A partir de resquícios de sacrifícios, cinzas e profecias encontradas nos arredores da residência de Germânico, este passou a acreditar que havia sido vítima de feitiçaria, e sua enfermidade consequência de um envenenamento; consequentemente, à renúncia formal da amizade entre ambos seguiu-se a saída de Pison da província ${ }^{355}$.

Pouco depois desta declaração pública de hostilidade - há dúvidas sobre a extensão da autoridade de Germânico em exigir a saída de Pison, uma vez que esta deveria se submeter à autoridade de Tibério, e retirar-se da província sem autorização era sinônimo de traição ${ }^{356}$ - Tácito afirma ${ }^{357}$ que Germânico, em seu leito de morte, pediu aos seus amigos mais íntimos que exigissem vingança perante o Senado, e para que mostrassem ao povo Agripina - como sua esposa e neta de Augusto, junto de seus seis filhos. Em contrapartida, para ela Germânico solicitou que controlasse sua rebeldia, resignasse seu espírito à crueldade do destino, e para que não rivalizasse em poder com seus superiores.

Após a morte de Germânico, Pison não retornou para Roma, mas celebrou publicamente a morte do príncipe ainda nas proximidades da província, o que teria sido suficiente para que imputassem culpa à sua pessoa. Mais ainda, logo depois Pison resolveu retornar à província - após ter se deparado com o cortejo naval que conduzia Agripina, seus consortes e as cinzas do falecido, e insultado os amigos de Germânico -, agregou soldados e

\footnotetext{
${ }^{354}$ SCULLARD, 2011, p. 230; SEAGER, 2004, p. 88.

355 Dion Cássio, 57.18.6-10; Tácito, Anais, 2.68-70; 2.78.

356 SEAGER, 2004, p. 89.

357 Anais, 2.71.3-4.
} 
organizou um exército. Persuadido por Domício Celer (e contrário aos alertas de seu próprio filho) de que teria o apoio de Tibério na empreitada, deparou-se com as tropas comandadas a partir de então por Gneio Sentio Saturnino (cônsul suffectus em 4 d.C.), novo governador da província designado pelo Senado e com o consentimento do Princeps, e acabou por ver seu motim desmembrado ${ }^{358}$.

Paralelamente, ao chegar à Itália, o cortejo fúnebre de Germânico recebeu um amplo cerimonial na Calábria, Apulia e Campânia, tendo sido escoltado por duas coortes pretorianas e, na medida em que se aproximara de Roma, teria sido acompanhado também por Druso, Cláudio (futuro Imperador), e seus filhos ${ }^{359}$. Contudo, ao chegar a Roma, nem Tibério, Lívia e sua mãe Antônia compareceram ao funeral. Em meio a isto, a população teria demonstrado em semelhante medida tanto descontentamento contra Tibério quanto afeição à Agripina, pois esta teria sido ovacionada com menções à sua descendência e preces para a preservação de seus filhos ${ }^{360}$. Por edito, Tibério determinou que o funeral respeitasse a moderação calcada nos precedentes de César e Augusto, e as cinzas do falecido príncipe foram depositadas no mausoléu da família imperial ${ }^{361}$.

O que de fato representou a morte de Germânico César? Em primeiro lugar, julgamos que há um exagero na apresentação de um Princeps satisfeito com a eliminação do mais provável sucessor ao comando. É plausível crermos em uma forte incompatibilidade de posturas políticas entre ambos: as evidências demonstram que tanto Germânico quanto Agripina conhecia bem o poder da popularidade que detinham pelos vínculos ancestrais com Marco Antônio, Druso Nero e Augusto (ou até mesmo Júlio César). A proximidade das legiões ao norte, a receptividade da população no Egito e a possibilidade do controle das legiões (extremamente fortes) no Oriente, provaram-se suspeitos a Tibério, e uma possibilidade de inversão no controle da domus imperial algo muito precipitado para os interesses do Princeps.

${ }^{358}$ Tácito, Anais, 2.74-2.81.; Cf. ALSTON, 1998, p. 26; SCULLARD, 2011, p. 230; SEAGER, 2004, p. 89-91.

${ }_{359}^{3}$ Tácito, Anais, 3.1-3.

${ }^{360}$ Idem, 3.4 .

${ }^{361}$ Ibidem, 3.4-5. 
Em contrapartida, é extremamente complicado corroborar o rumor de que o falecimento de Germânico pode ter sido um estratagema para assegurar a sucessão de Druso Cláudio e, portanto, manter a linha sucessória apenas dentro da família Cláudia: isso pode ser observado com a promoção dos filhos mais velhos de Germânico e a determinação deste último como guardião da prole, nos mesmos moldes iniciados por Augusto; e a concessão das prerrogativas imperiais emularam exatamente os passos que Augusto e Tibério percorreram em sua legitimação política ${ }^{362}$.

Tácito elenca algumas honras que teriam sido concedidas pelo Senado a Germânico César ${ }^{363}$, não obstante tenha omitido inúmeras outras presentes na Tabula Hebana e Tabula Siarensis, o que provavelmente denota seu propósito de intensificar a distância política entre o Princeps e o falecido, pois excluiu aquelas que foram decididas em última instância pelo Imperador: a participação de Tibério e outros membros da família imperial (Druso, Agripina, Lívia e Antônia) na escolha das honras; a permanência de celebrações anuais pela memória de Germânico no aniversário de sua morte; a difusão de uma publicação de conteúdo propagandístico dos discursos de Tibério e Druso sobre em honra do falecido príncipe; e a criação de novas centúrias com o nome de Germânico que, somadas às outras dez centúrias criadas em homenagem a Gaio e Lúcio César em 10 d.C., foram responsáveis pela designação dos candidatos às prefeituras e o consulado ${ }^{364}$.

Por fim, Pison retornou para Roma, e com isto Tibério deve ter se encontrado em uma situação bastante complicada. Enquanto associado político do Princeps, o primeiro provavelmente esperava um apoio equivalente aos serviços prestados e à honra da confiança nele depositada para acompanhar Germânico e, eventualmente, conter os impulsos do jovem príncipe. Provavelmente, Pison agira como amigo de Tibério, embora a diferença de personalidades e, principalmente, o lastro republicano de Pison tenha sido uma combinação que no final provou-se equivocada e trágica ${ }^{365}$. Martina, considerada como uma feiticeira, suposta amiga de sua esposa Plancina e

\footnotetext{
${ }^{362}$ LEVICK, 1999, p. 157; SEAGER, 2004, p. 93-5.

${ }^{363}$ Cf. Anais, 2.83.

${ }^{364}$ Respectivamente TS, fr. I, I.1-8; fr. Ila, I.1-11; fr. Ilb, I. 11-21; TH, I. 57-62; I. 5-50, apud GONZALEZ, 1999, p. 128-9; BRAUND, 1985, p. 51-5, n 115; ROWE, 2002, p. 22-30; SEAGER, 2004, p. 220.

${ }^{365}$ LEVICK, 1999, p. 155; SEAGER, 2004, p. 99; WIEDEMANN, p. 210.
} 
partícipe no crime de envenenamento foi presa na Síria, mas morreu misteriosamente no trajeto para a Cidade de Roma. Tibério, por sua vez, havia recebido imparcialmente seu filho Marco Pison, e lhe solicitado que levasse seus apelos ao Senado. Druso Cláudio, de modo semelhante, evitou aproximar-se de Pison e publicamente manifestou seu desejo de que as acusações contra ele fossem falsas e que ninguém mais sucumbisse ao destino de Germânico ${ }^{366}$.

Imediatamente organizou-se o julgamento: a despeito dos interesses de Fulcínio Trio (que atuou como acusador de Libo Druso) em monopolizar a acusação - certamente pela confiscação em jogo - Vitélio, Verânio e os demais amigos de Germânico intervieram, relegando ao primeiro apenas os fatos que diziam respeito à carreira prévia de Pison. Neste ínterim, conquanto os cônsules tivessem apelado para que Tibério participasse do julgamento, este julgou apropriada a condução do Senado, precisamente pelo falecido ser um membro da família imperial; a despeito de ter ouvido tanto os acusadores quanto os membros da defesa, isto indubitavelmente tolheu o apoio esperado por Pison ${ }^{367}$.

Ao passo que seus acusadores desejavam que Pison fosse condenado pelo assassinato de Germânico, Tibério deixou claro que, ao referendar o julgamento para o Senado, não desejava que sua influência determinasse o veredito. Igualmente, o Princeps abriu campo para a possibilidade de traição, ao solicitar que o Senado averiguasse o embasamento das acusações de corrupção e amotinamento das legiões ${ }^{368}$. Nesse sentido, a defesa de Pison não teve grandes chances: a despeito da autorização de Tibério para o comando das legiões, a forma como Pison havia incitado à desordem, bem como a desobediência somada à inimizade pública de Germânico eram inegáveis; o breve confronto com a legião de Saturnino era um indício de rebelião e guerra civil $^{369}$. Diante das fortes manifestações populares, da frieza dos senadores, e abandonado por Plancina, Pison não viu alternativa além do suicídio. Em uma carta deixada próxima de seu leito de morte, pediu que

\footnotetext{
366 Tácito, Anais, 3.7-9.

367 Idem, 3.10-12.

368 lbidem, 3.12.2-6.

369 Ibidem, 3.13.
} 
absolvesse seu filho mais novo Gneio por não ter sido envolvido, e Marco por ter seguido suas ordens, conquanto este o tivesse alertado do equívoco.

Ambos foram absolvidos a pedido de Tibério e Plancina a pedido de Lívia. De modo semelhante, Tibério impediu que metade da propriedade de Pison fosse confiscada e este fosse banido do Senado, que o nome de Pison fosse apagado da lista dos cônsules, pois nem Marco Antônio e lulo Antônio teriam sofrido esta desonra ${ }^{370}$. Embora tenha rejeitado a proposta de uma estátua e um altar no Templo de Marte Vingador (Mars Ultor), Tibério acolheu o agradecimento senatorial à sua pessoa, Lívia, Antônia, Agripina e Druso (Cláudio foi inserido posteriormente) pela vingança de Germânico; sacerdócios foram conferidos a Vitélio, Verânio e Serveu, bem como promessa de apoio à Fulcínio, salvo o conselho para que este último moderasse a violência de seu discurso ${ }^{371}$.

O senatus consultum de Pisone patre nos oferece uma importante evidência complementar sobre a maneira como reagiu Tibério perante 0 impacto que a morte de Germânico trouxe para a família imperial, e a forma como a continuidade desta deveria ser vista pelo Senado. Se na maior parte de seu conteúdo ele se assemelha à descrição feita por Tácito ${ }^{372}$, em contrapartida o caráter propagandístico do decreto senatorial evidencia como a punição a Gneio Pison referendou a estabilidade do governo de Tibério e a paz dentro da família imperial, iniciadas com Augusto, principalmente por reiterar a clementia do Princeps com a absolvição de Plancina e seus filhos ${ }^{373}$. Pison teria violado esta condição de coisas ao promover uma tentativa de guerra civil, e por esta razão sua memória deveria ser condenada ${ }^{374}$.

Após a descrição da pena, é importante destacar que o Senado reverenciou Tibério e o pediu para pensar sobre o futuro, um indício claro sobre a necessidade de se reafirmar a sucessão imperial, bem como deixar implícito que a memória de Germânico, conquanto devesse ser conservada, não teria função outra que não realçar as expectativas para o futuro do Principado. De sua parte, o Senado desejava que Tibério dirigisse todo o zelo uma vez dividido

\footnotetext{
370 Tácito, Anais, 3.15-7.

${ }^{371}$ Idem, 3.17-9.

${ }^{372}$ Cf. SCPP, I.12-68; 90-108.

${ }^{373}$ SCPP, I. 68-70; 90-4 apud ROWE, 2002, p. 13-4.

${ }^{374}$ SCPP, I. 90-108 apud ROWE, 2002, p. 14.
} 
entre seus dois filhos para aquele que ainda vivia; e que Druso contasse com toda a proteção dos deuses para que compreendesse que a continuação da observância recaia sobre ele, razão pela qual ele deveria aplacar o luto e retomar o estado para sua prosperidade ${ }^{375}$.

A nosso ver, embora a morte de Germânico tenha sido um duro golpe para os interesses políticos relativos ao núcleo familiar de Agripina, isto não significou que a sucessão imperial estivesse comprometida, pois três filhos poderiam ainda ser promessas eficazes para a sucessão imperial e em várias gerações: Nero (quinze anos), Druso (doze anos), e Gaio "Gaio César" (oito). Conquanto Nero fosse ainda muito jovem, um novo príncipe poderia ser seu preceptor: o próprio Druso Cláudio que, a despeito de ser pai de gêmeos do casamento com Lívia Júlia (filha de Druso Nero e Antônia, e viúva de Gaio César), eram ainda muito jovens (nascidos em 19 d.C.). Mais ainda, Tibério não aparentara disposição para romper com o precedente estipulado por Augusto em avançar os membros do núcleo familiar de Germânico César, a despeito da falta de sintonia entre ambos e de sua resiliência em relação a Agripina.

De modo semelhante, o fato de Druso e Germânico não terem tido diferenças pessoais ou políticas em vida teria sido um elemento facilitador para manter relativo equilíbrio dentro da casa imperial ${ }^{376}$. Em junho de 20 d.C., Tácito afirma ${ }^{377}$ que Nero, vestido com a toga viril, foi recomendado ao Senado por Tibério, tendo também solicitado aos padres conscritos que o isentassem das responsabilidades do vigintivirati, bem como pudesse disputar o cargo de questor antes da idade permitida, conforme Augusto fizera com ele e seu irmão Druso. Igualmente, Nero recebeu o direito de ingressar no sacerdócio, e ofereceu um donativo à plebe no seu primeiro dia de participação no fórum que, de sua parte ficara duplamente satisfeita em ver a maturidade de um membro da família de Germânico e por seu noivado com Júlia, filha de Druso.

\footnotetext{
375 SCPP, I.123-32 apud ROWE, 2002, p.17; SEAGER, 2004, p. 224.

${ }^{376}$ Tácito, Anais, 2.43.6.; SEAGER, 2004, p. 100. Barbara Levick afirma (1999, p. 124) que a ideia não desagradava Tibério, e o que o fato poderia ter sido surpreendente inclusive para a própria Agripina. Igualmente, não acredita que uma possível rivalidade entre Agripina e Lívia Júlia pudesse ter atrapalhado esta organização sucessória, tampouco que o nascimento dos gêmeos de Druso fosse um pretexto para a eliminação dos filhos da primeira e a recondução para a sucessão ao núcleo da família Cláudia.

${ }^{377}$ Anais, 3.29.1-4.
} 
Por outro lado, a mesma plebe recebera com hostilidade a notícia do noivado de Druso, filho de Cláudio com Urgulanila, com a filha de Sejano ${ }^{378}$.

$\mathrm{O}$ ano de 21 d.C. iniciou-se com Druso Cláudio exercendo o consulado em colegialidade com Tibério, embora pouco depois este tenha se retirado para a Campânia - para recuperar sua saúde, embora Tácito insinue ${ }^{379}$ que isto representava o começo das considerações para sua ausência definitiva -, e tendo deixado as responsabilidades para seu filho. Druso Cláudio teria adquirido uma boa credibilidade no Senado ao demonstrar poder conciliatório na recusa de uma proposta introduzida por Cecina Severo sobre o fim da presença das esposas de governadores nas províncias (o que aparentou ser uma indireta à presença de Agripina e Plancina), à condenação de Ânia Rufila por profanar uma imagem de Tibério, e a condenação dos equestres Consídio Équo e Célio Cursor por falsas acusações pelo crime de traição ao pretor Mágio Ceciliano ${ }^{380}$. Mais adiante, já durante o final de 22 d.C., Tibério - ainda na Campânia - enviou uma correspondência ao Senado pedindo a concessão do poder tribunício a Druso Cláudio, um passo significativo de seu caminho para a sucessão imperial.

O impacto político que a concessão desta prerrogativa trouxe para 0 ambiente político em Roma é dedutível pelo adendo de Tácito ${ }^{381}$, que evidencia sua utilização como a forma encontrada por Augusto para a legitimação de seu comando: da mesma forma como este foi recebido por Agripa e Tibério, este último concedia este elemento de supremacia a Druso, precisamente com a mesma idade, realçada por oito anos de serviços militares, uma ovação triunfal, e dois consulados; fato que foi amplamente divulgado com o reconhecimento da plebe de Roma já no ano seguinte ${ }^{382}$.

Sobre a real extensão da popularidade de Druso Cláudio, especialmente em comparação a Germânico, não podemos dizer se uma vez Princeps (tendo esperado o falecimento de Tibério, ou ascendido ao comando mediante uma abdicação formal deste, posto que já estivesse demonstrando distanciamento de Roma), Druso teria mantido o compromisso de proteger a prole do falecido

\footnotetext{
${ }^{378}$ Cujo nome é incerto. Cf. WOODMAN, 2004, p. 98, n. 80. Druso morreu tempos depois ao se engasgar com uma pera: Cf. Suetônio, Vida do Divino Cláudio, 27.1.

${ }^{379}$ Anais, 3.31.1-2; Suetônio, Vida de Tibério, 26.2.

${ }^{380}$ Tácito, Anais, 3.33-7.

381 Anais, 3.56.1-3.

${ }^{382}$ ILS, 168, 176 [EJ 92].
} 
príncipe para a manutenção do esquema sucessório de Augusto. Por outro lado, talvez tivesse sido melhor para Agripina do que o futuro a ela reservado a partir da ascensão de Sejano ${ }^{383}$.

Nesse sentido, a reversão no panorama da família imperial é bem apresentada por Tácito. Em 23 d.C., Tibério experimentava seu nono ano de governo em meio à calmaria nos assuntos públicos e a florescência em sua residência, quando a Fortuna tornou-se rompente, e a razão estivera na presença do prefeito da guarda pretoriana ${ }^{384}$. O primeiro abalo fora a morte de Druso, à qual a documentação atribuiu envenenamento sob as instruções de Sejano ${ }^{385}$, e suas implicações foram decisivas para a mudança no ambiente da corte imperial; daremos continuidade a este assunto.

De antemão, acreditamos que as implicações de sua morte são perceptíveis na pena de Suetônio, que afirma ${ }^{386}$ que após a perda de Germânico César e Druso Cláudio, Tibério resolveu se retirar para a Campânia, e com esta decisão quase todos decididamente acreditaram e abertamente declararam que ele jamais retornaria, e que em breve lá poderia morrer. Embora o Princeps ainda tivesse mais de uma década de poder pela frente, que os acontecimentos dos próximos três anos ainda agregassem novas e significativas implicações para sua tomada de decisão, e que a morte dos dois prováveis sucessores não foi isoladamente o único pretexto para o seu afastamento de Roma, o desmantelamento de mais uma estratégia sucessória - para não nos conformarmos somente com razões afetivas - foi um grande revés político.

Observamos no subcapitulo anterior que a ascensão de Tibério configurou-se como uma missão de estabelecer o controle dentro da corte imperial. Esta tarefa não foi simples: a morte de Agripa Póstumo deixou implícito que perdurava ainda uma animosidade que era evidência de interesses em conflito. Embora não possamos falar de contenda entre facções, havia uma disputa entre representantes de núcleos das famílias Júlia e Cláudia, cujo objetivo era proeminência em uma eventual sucessão. A morte de

\footnotetext{
383 LEVICK, 1999, p. 125.

384 Anais, 4.1.1.

385 Dion Cássio, 57.22.1; Tácito, Anais, 4.4-8.

386 Vida de Tibério, 39.
} 
Agripa Póstumo, filho caçula de Júlia Augusta, e o isolamento desta e sua filha Júlia Menor não arrefeceram os ânimos.

O consciente apelo popular angariado e sentido por Germânico César e Agripina Maior também gerou desconfiança em Tibério, bem como provavelmente em Lívia Drusila ou mesmo Lívia Júlia, irmã de Agripina. Embora fosse presumível que o caminho natural desembocasse em uma futura ascensão de Germânico, as demonstrações de apoio popular ou mesmo as decisões (por vezes impetuosas) tomadas à frente do campo de batalha ou entre os provinciais ampliaram suspeitas, que encontraram terreno fértil diante de uma intrínseca falta de empatia do Princeps por seu sobrinho e enteado. Assim, os primeiros anos de governo de Tibério demonstraram desde o início que o primeiro, senão o principal desafio do Princeps foi o de assegurar que 0 novo sistema político não entrasse em crise dentro da própria residência imperial.

A morte de Germânico César não foi o principal sintoma da iminente crise que se instalaria na corte, mas apenas a segunda evidência. A nosso ver, o falecimento de Druso Cláudio criou um problema de interlocução política para Tibério: o Princeps se viu obrigado a contar (ou se tornou cada vez mais suscetível ao) com o apoio de Lúcio Aélio Sejano. Embora sejamos reféns da tradição histórica presente na documentação (Sejano passa a ser incorporado na narrativa a partir deste momento), a participação deste último trará um impacto para o processo de sucessão dinástica, e também para a relação do Princeps com o Senado, que desde o início do governo de Tibério não foi fácil.

Consequentemente, veremos que o entrecruzamento destes fatores contribuirá para ampliar o impacto político provocado pelo afastamento de Tibério para Capri, uma vez que Sejano interferirá cada vez mais explicitamente na interação entre a corte imperial e os membros da aristocracia senatorial e equestre, nos fluxos de informações concernentes à administração da justiça, e principalmente, minará sistematicamente as bases de apoio do núcleo familiar de Agripina. Podemos antecipar que Sejano contribuirá para orientar a maneira como o Princeps e os integrantes da corte imperial presentes em Capri se relacionarão com o restante daqueles que permaneceram em Roma, uma vez que se tornará perceptível que, com o afastamento de Tibério da Cidade de Roma, o centro decisório residirá onde o 
Imperador estiver e, o deslocamento do cerne do poder imperial somado à dificuldade de acesso à pessoa de Tibério e à sua corte se configurará como 0 grande experimento político de seu Principado. Sejano será aquele que, por um lado, permitirá que o Princeps dê vazão ao experimento político de constituir uma corte e um centro decisório de poder fora de Roma; por outro lado, será também o responsável por agravar a delicada situação política entre os parentes do Imperador e interferir cada vez mais na complexa relação entre Tibério e o Senado. 


\section{2 - Tibério e o Senado (14 - 26 d.C.): Princeps senatus}

Os eventos ocorridos no ambiente da Domus Caesaris se relacionaram às interações entre Tibério e o Senado, e a nosso ver é impossível discutir ambos em separado ou privilegiando um em detrimento do outro. Ampliemos agora nosso enfoque para o segundo aspecto. Para tanto, pouco após 0 falecimento de Augusto, Dion Cássio afirma ${ }^{387}$ que embora não tivesse se proclamado como Imperador, Tibério teria agido como tal mediante o envio de correspondências às legiões e províncias. Constatação semelhante é apresentada por Suetônio ${ }^{388}$, indicando que o Princeps não hesitou em aceitar o Principado, fato demonstrado pelo imediato aparecimento público em meio aos soldados - indício efetivo de soberania. Contudo, ambos os autores insistem que Tibério ainda recusara o título por bastante tempo ${ }^{389}$.

Ainda neste contexto, Tácito também associa ${ }^{390}$ o envio de uma notificação à guarda pretoriana como efetiva demonstração de comando; o encaminhamento de correspondências para as legiões teria representado sua ascensão como soberano e a posse (adipsci) do Principado. A data da chegada do corpo de Augusto em Roma provavelmente ocorreu em quatro de Setembro, e a cremação teria ocorrido quatro dias depois ${ }^{391}$. Possivelmente antes disso, Tácito afirma ${ }^{392}$ que teria havido uma precipitação à servidão por parte dos cônsules, senadores e equestres: Sexto Pompeu e Sexto Apuleio, cônsules daquele ano, teriam sido os primeiros a jurar aliança ao novo Princeps; na presença destes S. Estrabão e C. Turrânio, respectivamente prefeito da guarda pretoriana e prefeito da distribuição de grãos na Cidade de Roma, também seguiram o exemplo, e por último empreenderam o pacto os demais senadores, soldados e a população.

Conforme os principais representantes da administração imperial em Roma, Senado e ordem equestre se apressaram em demonstrar compromisso

\footnotetext{
${ }^{387}$ Dion Cássio, 57.2.1.

388 Suetônio, Vida de Tibério, 24.1.

${ }^{389}$ Dion Cássio, 57.2.1; ST 24.1.

390 Tácito, Anais, 1.7.5.

${ }^{391}$ Cf. LEVICK, 1999, p. 49-50.

392 Tácito, Anais, 1.7.1.
} 
a Tibério, Tácito complementa ${ }^{393}$ que de fato seu governo teria começado como era durante a República: a convocação dos senadores para a câmara senatorial teria se dado apenas mediante a prerrogativa de seu poder tribunício recebido de Augusto, e as instruções tratavam exclusivamente de sua presença próxima ao caixão e a responsabilidade pelo funeral ${ }^{394}$.

Durante a cerimônia, que provavelmente ocorrera em quatorze de Setembro, Tibério não teria conseguido pronunciar o elogio a Augusto, que ficara a cargo de Druso Cláudio. Suetônio afirma ${ }^{395}$ que o testamento foi lido por um liberto apenas aos membros da ordem senatorial: uma vez privado de seus filhos Gaio e Lúcio César, Tibério seria o herdeiro de dois terços do espólio. Além disso, Lívia teria recebido a parte restante, associada à família Júlia com o recebimento do prenome 'Augusta'396, e outros membros da família imperial, proeminentes aristocratas, soldados e a plebe recebido benefícios ${ }^{397}$.

Após um debate sobre a concessão das honras concernentes a Augusto durante seu funeral, o senador Valério Messala sugerira que o pacto de fidelidade às ações de Tibério fosse renovado anualmente. Diante desta proposta, Tibério teria questionado incisivamente este senador, querendo saber se fora mediante seu próprio interesse que tal sugestão proposição surgira. Em réplica, Messala respondeu que havia sido espontâneo e que em relação aos assuntos que envolviam o interesse público ele não se apoiaria em nenhum outro julgamento que senão o próprio, mesmo que a alguém ofendesse ${ }^{398}$.

Após a cremação do corpo e deificação de Augusto $^{399}$ ocorreu um período de luto que antecedeu ao segundo encontro com o Senado, o primeiro em que de fato se tratou das questões políticas envolvendo o futuro da res publica e perante seu novo soberano. Em verdade, o hiato de quase um mês entre a morte de Augusto e este encontro aparentou a existência de uma demora na aceitação do governo por parte de Tibério, impressão reforçada pelo relato oferecido por Dion Cássio, Suetônio e Tácito, mediante a descrição

\footnotetext{
393 Idem, 1.7.2.

394 Tácito, Anais, 1.7.3-4; Suetônio, Vida de Tibério, 23.

395 Suetônio, Vida de Tibério, 23.

${ }^{396}$ Durante o texto manteremos o nome de "Lívia Drusila".

397 Tácito, Anais, 1.8.3.

398 Idem, 1.8.3-4.

399 Ibidem, 1.8.6, 1.10.8; Veléio Patérculo 2.124.3, 2.126.1.
} 
de um diálogo embaraçoso entre aflitos membros do Senado e um Princeps aparentemente hesitante.

Neste novo encontro, Tácito afirma ${ }^{400}$ que Tibério iniciou o debate com um discurso em que enfatizava aos senadores a grandeza do Império, suas limitações pessoais e a conclusão de que somente uma mente como a de Augusto foi capaz de tamanha empreitada; por ter compartilhado das responsabilidades deste último, a experiência havia the ensinado como era íngreme e imprevisível o fardo de tudo governar, e em meio à grande quantidade de homens ilustres, as responsabilidades do Estado seriam mais facilmente suportáveis com o apoio de muitos. Diante desta fala e em meio à forma insistente como diversos senadores reagiram, Tibério teria reafirmado a dureza desta tarefa, mas passado também a censurar estes senadores. Além disso, sua idade avançada e seus problemas de visão também seriam impeditivos alegados pelo Princeps ${ }^{401}$ diante das responsabilidades do comando.

Sua proposição não parece ter ganhado muitos adeptos, com variadas reações de insatisfação ${ }^{402}$. Tibério prosseguiu com a apresentação de um documento que continha a descrição dos principais recursos públicos, o contingente de cidadãos e auxiliares no Exército, a quantidade de embarcações navais, protetorados e províncias, taxas e arrecadações, e ainda os gastos e as concessões públicas - todas listadas à mão por Augusto, junto de uma recomendação para manter o Império dentro de seus limites territoriais $^{403}$. Em meio a esta situação, Tibério sugeriu aos senadores a possibilidade de assumir a tutela de qualquer parte do Estado que por eles the fosse confiada e em conformidade com o que melhor os conviesse, pois ninguém seria capaz de tamanha responsabilidade sem um colega, quiçá com vários ${ }^{404}$.

Desta maneira, O Princeps clamara por alguns associados, embora não com a intenção de que devessem conjuntamente governar todo o Império, como se estivessem em uma oligarquia, mas ao invés disso dividindo-o em três

\footnotetext{
${ }^{400}$ Tácito, Anais, 1.11.1.

${ }^{401}$ Dion Cássio, 57.2.4.1; Suetônio, Vida de Tibério, 24.1.

402 Suetônio, Vida de Augusto, 24.1; Tácito, Anais, 1.11.3.

${ }^{403}$ Tácito, Anais, 1.11.3.

${ }^{404}$ Dion Cássio, 57.2.4; ST 25.2; Tácito, Anais, 1.12.1.
} 
partes e assumindo uma dessas em detrimento das restantes. Sendo assim, a primeira parte consistiria da Cidade de Roma e do restante da Itália, a segunda parte consistiria das legiões e a terceira do restante da população e das províncias $^{405}$.

Entretanto, quando Tibério tornara-se insistente em consideração a este assunto, a maioria dos senadores ainda contrariou seu anunciado propósito e Ihe implorou para que governasse o Estado como um todo ${ }^{406}$. Neste ínterim, o senador Asínio Galo teria então questionado a Tibério qual parte do Estado este gostaria que the fosse confiada. Abalado pela pergunta, após certo silêncio e recomposição, este último teria respondido que não era conveniente escolher ou evitar nenhum elemento de algo que preferiria ser completamente isento $^{407}$.

A pergunta parece não ter causado uma boa impressão a Tibério. Galo teria tentado se justificar dizendo que a questão não teria sido colocada ao Imperador com a intenção de que este dividisse o que não pudesse ser separado, mas admitisse mediante sua confissão que o Estado era uno e precisava ser governado pela mente de uma única pessoa: o Princeps não deveria ficar com apenas uma das partes, mas observar que o Império era indivisível ${ }^{408}$.

Por fim, os senadores Quinto Hatério e Mamerco Escauro teriam também questionado a posição de Tibério, com o primeiro tendo desejado saber por quanto tempo mais Tibério não se permitiria assumir o Estado. Outros teriam inclusive ficado contrariados e impacientes; em meio à confusão, ao Princeps teria sido dito que este escolhesse a parte que desejasse, escolhesse ou desistisse, ou mesmo que Tibério era lento em reconhecer o que já estava fazendo ${ }^{409}$. Em meio a estas reações, o senador Escauro por fim afirmara haver esperanças de que as súplicas dos senadores não fossem em vão, uma vez que Tibério não havia usado o seu poder tribunício em veto à moção dos cônsules ${ }^{410}$.

\footnotetext{
${ }^{405}$ Dion Cássio, 57.2.4-5.

${ }^{406}$ Idem, 57.2.5.

407 Ibidem, 57.2.5; Tácito, Anais, 1.12.3.

408 Ibidem, 57.2.7; Tácito, Anais, 1.12.3.

${ }^{409}$ Suetônio, Vida de Tibério, 24.1; Tácito, Anais, 1.13.4.

${ }^{410}$ Tácito, Anais, 1.13.4.
} 
Não sabemos o que de fato contivera nesta moção, e tampouco quais prerrogativas políticas teriam sido validadas pelo Senado. Tácito complementa $^{411}$ que, ao final do debate, Tibério finalmente aquiescera diante dos apelos individuais e imprecações coletivas, e com isso cessara a recusa ao poder, embora sem admitir que assumira o comando. De modo semelhante, outro desfecho é dado por Dion Cássio ${ }^{412}$, em que é apontado que Tibério, ao ter percebido que a população se mostrou favorável em relação à sua pessoa, esperou e procrastinou a confirmação de sua posição política até ter se tornado soberano do Império.

Em linhas gerais, a documentação nos transmite a impressão de que Tibério se mostrou hesitante em assumir o seu poder perante o Senado. O que teria variado fora o tempo que o Princeps teria precisado para se certificar de que não havia mais animosidades ou possíveis ameaças à sua soberania. Neste sentido, os motins militares, a popularidade de Germânico César e Agripina perante as tropas na fronteira e na Gália, a possível tentativa de reabilitação política de Agripa Póstumo, sua mãe e sua irmã, e a conspiração de Marco Escribônio Libo Druso teriam sido os fatores que, explicitamente em Dion Cássio e Suetônio, teriam postergado o que já era evidente, o fato de que o Império era indivisível e precisava de um soberano, e que alternativas a isto não levariam a coisa outra que não a rebelião ou guerra civil.

Provavelmente este exame posterior da historiografia sobre o governo dos Imperadores Júlio-Claudianos, somados a uma tradição hostil ao governo de Tibério, tenham permitido que a hipocrisia do governante fosse uma explicação mais plausível para uma aparente indefinição do Imperador perante a necessidade de assumir a condução do Império. A nosso ver, o assassinato de Agripa Póstumo foi importante como forma de eliminar uma possível ameaça; as rebeliões também não devem ser menosprezadas, uma vez que envolveram uma parte significativa do exército romano: o temor de uma guerra civil ainda não havia sido completamente apagado pela memória sobre o final da República, e por outro lado a preocupação com os germanos para além das fronteiras fizera parte da agenda de Augusto principalmente na última década de seu governo. Todavia, o fim dos motins pode ter coincidido com a

\footnotetext{
${ }^{411}$ Tácito, Anais, 1.13.5.

${ }^{412}$ Dion Cássio, 57.3.3-4.
} 
confirmação de Tibério no poder, mas isto não ocorreu como resultado do fim das perturbações militares ${ }^{413}$.

Se houve alguma dúvida que pairou sobre o ambiente político imperial com a ascensão de Tibério, certamente não consistiu em saber se o Princeps queria ou não assumir o poder, mas sim de que maneira ele desempenharia 0 papel de soberano. Esta questão relaciona-se diretamente com o processo político engendrado por Augusto durante as quase cinco décadas de governo. De fato, com seu antecessor nenhum precedente formal foi estabelecido: em certa medida, Tibério sobreviveu a Augusto e obteve uma posição de poder equivalente a de Agripa em 12 a.C., com a diferença de que o primeiro sobreviveu ao próprio Princeps.

A década posterior à adoção de Tibério serviu para disseminar a orientação de que ele seria o sucessor de Augusto, pela conferencia de títulos e pela demonstração de um consentimento que afirmasse que Tibério era 0 (único) candidato para o posto. Quando Augusto faleceu, Tibério estava em seu décimo sexto ano de poder tribunício, era colega imperii de Augusto autoridade nas províncias orientais equivalente a do último e superior à dos governadores de província, estendida também à Cidade de Roma e, portanto, superior também à dos cônsules: tribunicia potestas e imperium maius, estes eram os grandes poderes do Princeps, resultado do acordo estabelecido em 23 a.C., conquanto sem protocolo ou rito político de passagem, além do consentimento do Senado e o povo de Roma em relação aos passos políticos dos príncipes da família imperial, indícios estabelecidos desde Marcelo com elementos que denotavam a vontade do soberano para a mais pacífica transição possível.

Quanto à auctoritas, a deificação de Augusto transformou Tibério em um Divi filius, assim como ocorrera com o primeiro após a morte e deificação de Júlio César, e detentor do título 'Augusto' por herança. Deste modo, a supremacia do novo Princeps não foi posta em questão, ou pelo menos não fora abertamente confrontada dentro do Senado. Mais do que isso, tendo em vista a narrativa oferecida no conjunto da documentação sobre os primeiros encontros com o Senado, somos levados a crer no fato de que não houve um

${ }^{413}$ LEVICK, 1999, p. 53-4. 
dia de aceitação dos poderes (o convencionado dies imperii) ${ }^{414}$, mas sim um debate sobre o que para o Senado significara os poderes que Tibério herdara pelo testamento de Augusto, e de que maneira ele manteria, a partir de então, sua relação com esta e as demais instituições republicanas ${ }^{415}$.

Neste sentido, podemos construir uma reflexão a partir de evidências em Dion Cássio. Em seu balanço sobre o governo de Augusto, o autor afirma ${ }^{416}$ que sua contribuição teria sido a combinação de monarquia e democracia, a liberdade dos romanos e a preservação da segurança e da ordem; a liberdade da moderação sem a licenciosidade da democracia e a insolência da tirania, súditos e cidadãos sem discórdia: o restabelecimento da res publica sem a discórdia entre as facções, e com um poder maior e mais fortalecido. Evidentemente, a perspectiva de Dion Cássio contou com toda uma reflexão posterior de mais de dois séculos para a elaboração desta síntese.

De todo modo, é interessante percebermos que Dion Cássio observa a diferença de personalidades entre Augusto e Tibério, o que nos ajuda a corroborar que o governo de Tibério não foi uma mera continuidade, mas como todo novo governo imperial, marcado por experimentações e aspectos próprios; a morte deste Princeps foi também o anúncio de uma transformação evidente, pois Tibério era um homem diferente ${ }^{417}$. A moção encaminhada mediante os cônsules para o Princeps certamente disse respeito a uma definição (ou confirmação) do posto do Princeps como soberano.

A despeito da aparência de embuste, não podemos simplesmente considerar que os embates iniciais entre o Princeps e o Senado durante os primeiros encontros oficiais não tenham sido envolvidos por questões políticas genuínas. Conquanto sua narrativa carregue uma perspectiva "oficial" dos fatos, Veléio Patérculo afirma ${ }^{418}$ que em meio à trepidação do Senado e os temores na Cidade de Roma, a segurança e ruína estiveram separados por um limite estreito, mas não que sofrera nenhum distúrbio devido à majestade de Tibério.

\footnotetext{
${ }^{414}$ Embora a análise sobre a cronologia que envolveu o falecimento de Augusto, a notificação das tropas, o começo dos motins, e o ínterim que envolveu estes fatos e os primeiros encontros com o Senado - e suas consequências - seja muito bem construído por Wellesley (1967, p. 23-7).

${ }_{415}$ KAMPFF, 1967, p. 27-32; LEVICK, 1999, p. 54-6; OBER, 1982, p. 326-8.

${ }^{416}$ Dion Cássio, 56.43.4; 56.44.2.

${ }^{417}$ Idem, 56.45.1.

${ }^{418} 2.124 .1$.
} 
Mais ainda, teria havido um embate entre este e o Senado para que ele sucedesse ao posto de seu pai, ao passo que o último buscara dos senadores a permissão para agir mais como um cidadão em paridade aos demais do que como um princeps. Ao final deste embate, Tibério teria sido persuadido e percebido que, sob sua pessoa, tudo o que não protegesse poderia perecer caso continuasse a recusar o principado por quase tanto tempo quanto outros lutaram para assegurá-10 ${ }^{419}$.

É provável que Veléio Patérculo, contemporâneo e associado do Princeps, bem como outros apoiadores de Tibério e do regime iniciado com Augusto, soubessem que este novo governo era um sistema político diferente; uma ruptura dos antigos moldes republicanos, conquanto o Principado ainda não possuísse uma caracterização e designação mais bem definida como naturalmente o seria durante o período de Tácito, Suetônio e Dion Cássio. Mesmo em Tácito, cuja narrativa configura-se (com seus méritos e dificuldades) como o mais detalhado relato sobre o governo de Tibério, este autor estabelece uma tensa relação entre a percepção de que a fachada de sustentação de um restabelecimento da República é derrubada após o fim do Principado de Augusto, e uma memória da res publica enquanto nostalgia de um período que está claramente relegado ao passado.

Existe em Tácito (e na tradição da qual ele se valeu) a consciência de que o "restabelecimento da República" não significou uma verdadeira tentativa por parte do Imperador de restabelecer a autoridade do Senado nos moldes existentes antes da segunda metade do século I a.C., percebendo que a utilização do termo pelos sucessores Júlio-Claudianos respondeu a novas necessidades políticas, e um esvaziamento do sentido anterior da palavra. Todavia, podemos perceber a memória da República repaginada e remodelada para atender a um novo propósito: a República caracterizada pela autoridade soberana do Senado foi relegada ao passado, e a presença do Imperador com sua palavra final o marco desta mudança. Contudo, a memória política do Principado permaneceu entremeada a estas práticas republicanas, haja vista que a permanência do termo e sua rememoração serviram como maneira de reiterar o prestígio social e político da aristocracia senatorial romana, da qual

${ }^{419}$ Veléio Patérculo, 2.124.2. 
dependia o Princeps e com a qual este último deveria sempre relembrar e reiterar seu vínculo de cooperação ${ }^{420}$.

O significado dos primeiros encontros de Tibério com o Senado nos serve como evidência para a compreensão de que o início de seu governo já apontava para o delicado conflito de posições entre o Imperador e esta instituição, e se constituiu como um indício do que ocorreria durante o restante de seu governo. Neste sentido, o equivoco não residiu no exame de sua aceitação ou não dos poderes, mas sim na falta de percepção do que Tibério faria com os mesmos a partir de então; provavelmente este último tivera de reconhecer que o resultado das experimentações políticas de seu antecessor e a detenção de poderes idênticos aos dele é que the fariam um soberano, e que seria com esses elementos que ele deveria redefinir e/ou reafirmar seu posto, tarefa que, conforme demonstrado pela tensão dos primeiros debates senatoriais, não foi algo simples, e cujo desgaste não arrefeceria pelos próximos anos, fato que também influenciará o seu afastamento de Roma.

Os debates expuseram a dificuldade de convencer os senadores de que Tibério talvez quisesse exercer a soberania legada por Augusto sem ceifar por completo a iniciativa política desta aristocracia. De modo semelhante, expuseram como seria complicado modificar o sistema resultante da experimentação política à qual ele deveu sua própria legitimidade, e ao mesmo tempo não forçar os senadores a desempenharem um papel de autonomia que eles temiam, não acreditavam, ou não estavam mais dispostos a fazê-lo. Consequentemente, o governo de Tibério apresentou as dificuldades de uma conciliação concreta entre as práticas deliberativas republicanas e a existência de facto de um Princeps, e de um ajuste dos comportamentos tradicionais às novas condições políticas.

Tal panorama não se originou ou foi exclusivo ao governo de Tibério. Sem dúvida, isto adveio como uma difícil herança de Augusto, intrínseca à própria essência do Principado, não obstante Imperador e o Senado estivessem de acordo em conservar a esta instituição uma elevada posição de importância, pela própria correlação que 'Senado' possuía com 'República'.

${ }^{420}$ CIZEK, 2003, p.28-9; GOWING, 2005, p.26-32. 
O governo de Tibério explicita - principalmente por ter sido relativamente bem documentado - as dificuldades que se mantiveram sob seus sucessores em consideração a um esforço de adequação e preservação de um equilíbrio entre a autoridade imperial e a iniciativa senatorial; estes dois componentes demandaram espaço dentro do sistema político do Principado, de forma mais ou menos harmoniosa, mas sempre tênue e instável. Em outras palavras, o Principado de Tibério serviu como uma demonstração de o quanto era difícil a harmonização entre uma instituição que representava o conjunto de uma tradição e outra, que embora não desejasse seu esfacelamento, não abriu mão da condução das decisões políticas e da sociedade ${ }^{421}$.

Consequentemente, o período em que Tibério permaneceu em Roma pode ser sintetizado como o governo de um Princeps disposto a fazer com que o prestígio da instituição senatorial fosse evidenciado: o Senado deveria ser um organismo ativo e atuante na administração do Império. Pelo menos assim foi caracterizado em sua maior parte, mesmo em Tácito ou Dion Cássio. Neste sentido, Veléio Patérculo afirma que logo todos colheram os frutos pela escolha de Tibério, após os conflitos entre as legiões ${ }^{422}$; a credibilidade havia sido restaurada aos magistrados e as contendas banidas do fórum, o assédio por apoio eleitoral banido das assembleias populares, a discórdia do Senado; justiça, equidade e diligência restituídas. Foi adicionada autoridade aos magistrados, majestade ao Senado, e dignidade às cortes ${ }^{423}$.

Para Tácito ${ }^{424}, 23$ d.C. teria sido o nono ano de uma República em ordem, embora o destino subitamente tenha invertido esta situação. No que diz respeito aos assuntos públicos, estes - em conjunção às questões privadas excepcionais - foram abordados no Senado, e o debate fora livre para os seus mais ilustres membros, porquanto a subserviência fosse fiscalizada pelo próprio soberano. Na conferência de magistraturas, Tibério teria considerado a nobreza da linhagem do candidato, sua conduta militar, e a relevância de suas realizações políticas, tendo deixado claro que a escolha dos candidatos estivesse relacionada às qualidades dos mesmos. $O$ consulado e o pretorado mantiveram o seu prestígio, os poderes dos magistrados menores foram

\footnotetext{
${ }^{421}$ BONNEFOND-CONDRY, 1995, p. 232-55; LEVICK, 1999, p. 58-9; SEAGER, 2004, p. $46-7$.

422 Veléio Patérculo, 2.125.1-2.

423 Idem, 2.126.1-3.

424 Tácito, Anais, 4.1.1.
} 
exercidos, e as leis - com a exceção dos processos por crimes de traição foram bem utilizadas ${ }^{425}$.

Suetônio afirma ${ }^{426}$ que Tibério inicialmente teria agido como um concidadão e com uma humildade semelhante à de um indivíduo privado; aceitou poucas das várias honras e ele propostas, como os votos ao seu aniversário, templos, flâmines, sacerdócios, e mesmo estátuas ou bustos sem sua permissão, ou que fossem erigidas em proximidade aos monumentos das divindades, e igualmente o prenome de "imperador" (imperator), o título de "pai da pátria" (pater patriae), a coroa cívica, e "Augusto" (Augustus) só fora permitido em correspondências imperiais.

Tibério recusara inclusive o pacto de obediência às suas ações, conforme oferecido pelo Senado; para ele, todas as questões que envolviam os mortais eram incertas: quanto mais alto estivesse, mais escorregadia era a sua posição. O Princeps também teria evitado a adulação, não hesitando em interromper seu interlocutor para que 0 interpelasse apropriadamente. Contrário à denominação de senhor e à caracterização de seus afazeres como sagrados, Tibério se considerava como um conselheiro para o Senado ${ }^{427}$. Dion Cássio afirma ${ }^{428}$ que, a despeito de ter sido chamado por vezes de César, de Germânico (em decorrência dos feitos de Germânico César), Tibério preferira a designação de "chefe [ou príncipe] do Senado" (Princeps Senatus), por atender ao sentido da antiga atribuição republicana, pela qual costumeiramente declarava que era senhor dos escravos, imperator dos soldados, e líder dos demais.

Mesmo diante de injúrias a si e à família imperial, Tibério teria sido inicialmente mais paciente: dizia que em uma comunidade livre deveria haver liberdade de expressão e pensamento, e que a preocupação com as ofensas não permitiria que houvesse tempo hábil aos senadores para os outros afazeres; as mesmas seriam desculpas para que todas as querelas fossem levadas à instituição ${ }^{429}$. Tanto nas assembleias quanto pessoalmente, 0 Princeps teria sido extremamente cordial ao se dirigir aos senadores, de quem

\footnotetext{
${ }^{425}$ Tácito, Anais, 4.6.2.

${ }^{426}$ Suetônio, Vida de Tibério, 26.1-2; Tácito, Anais, 1.72.1, 2.87.1.

${ }^{427}$ Dion Cássio, 57.8.4-5; Tácito, Anais, 1.72.1; ST 27.

${ }^{428}$ Dion Cássio, 57.8.2.

${ }^{429}$ Suetônio, Vida de Tibério, 28.
} 
havia recebido grande e irrestrito poder, seus bons, justos e indulgentes senhores.

Além das honras anuais aos magistrados eleitos, o acesso à sua pessoa teria sido extremamente facilitado, principalmente com o intuito de evitar eventuais conflitos pela sua atenção. No âmbito privado, Tibério teria sempre os entretido durante os jantares feitos em sua residência, sempre tendo os recebido e os acompanhado enquanto estes estivessem na residência imperial, intercedia por estes nas questões jurídicas ou em celebrações religiosas, e tendo do mesmo modo os visitado em suas enfermidades e feito elogios fúnebres quando estes morriam ${ }^{430}$.

Deste modo, a conduta de Tibério em relação aos magistrados, tanto no ambiente público quanto privado, é caracterizada por uma preocupação inicial de não colocar sua pessoa acima da instituição e seus membros em Roma. Igualmente, sua postura de cooperação com as magistraturas e o desempenho das respectivas atribuições dos senadores escolhidos para os cargos fizera com que o Senado adquirisse uma notória condição de corte de justiça, cujas responsabilidades não ficaram restritas à existência do consilium principis. Dion Cássio $^{431}$ afirma que um tribunal teria sido construído em Roma para que Tibério participasse das sessões no Fórum, junto dos magistrados e sempre acompanhado de um consorte de senadores associados, como fizera também Augusto.

Tibério teria introduzido uma aparência de liberdade ao seu governo pela manutenção do antigo prestígio e dos poderes do Senado e seus magistrados; nenhum assunto público ou privado foi excluído do conhecimento dos senadores, mesmo quando decretos eram contrários à sua expressa opinião ou propostos por uma minoria, da mesma forma como outras questões fossem exclusivamente conduzidas apenas pelos magistrados ou cônsules ${ }^{432}$.

Diante do mesmo semblante de liberdade política oferecido à instituição senatorial, Tibério garantira amplo direito à fala e à oposição de suas ideias em público, e de modo semelhante seu filho - e também por vezes cônsul - Druso Cláudio também agira mediante este princípio; e ambos pronunciavam suas

\footnotetext{
430 Dion Cássio, 57.11.1-7.

${ }^{431}$ Idem, 57.7.2.

432 Ibidem, 57.7.1; ST 29-31.2.
} 
ideias de maneira variada, geralmente buscando deixar a impressão de que agiam como conselheiros, tendo Tibério por vezes presidido sessões ou simplesmente se imiscuído às mesmas - com ou sem convite, embora sempre se posicionando a um canto do tribunal como uma espécie de assessor ${ }^{433}$.

Outra reflexão sobre este esforço nos é reportado por Tácito, ao afirmar $q^{4} e^{434}$, a despeito de este período ter sido maculado e comprometido pela adulação dos senadores, não somente os líderes da comunidade, mas todos os consulares, a maioria dos pretores mais proeminentes, e mesmos os senadores abaixo deste ranque, competiram entre si na exposição de sugestões para o Princeps. Este autor não isenta a aristocracia, da qual ele mesmo fizera parte, de parte da responsabilidade por ter se tornado uma instituição subordinada aos desígnios do soberano. O ônus advindo deste estímulo parece evidente, uma vez que o autor complementa ${ }^{435}$ que por várias vezes, quando Tibério deixava a Cúria, dizia em grego o quanto os senadores eram propensos à servidão; curiosamente, Tácito ironiza ${ }^{436}$ que mesmo um Princeps que desaprovava a liberdade pública demonstrava verdadeira aversão à prontidão para a passividade dos senadores.

Mediante esta observação da relação cotidiana de Tibério com o Senado, e as necessidades práticas da administração imperial, podemos concluir que existiram duas tarefas essenciais promovidas pelo Princeps. A primeira delas teria sido a de assegurar que a instituição senatorial abarcasse todas as responsabilidades legítimas ao seu prestígio e esfera de atuação, e a segunda era a de garantir que o Senado por si mesmo deliberasse sobre as questões que julgasse realmente importantes.

Em consideração à primeira, uma vez que Augusto já havia estabelecido a existência do consilium com todas as suas funções preparatórias para a apresentação de demandas ao Senado, durante a permanência de Tibério em Roma este comitê adquiriu características peculiares, e não exatamente igual ao de Augusto: consistiu não apenas dos mais próximos associados do Princeps, mas de vinte senadores provavelmente designados pelo próprio Senado. Embora tenha mantido uma grande semelhança com o consilium de

\footnotetext{
${ }^{433}$ Dion Cássio, 57.7.3-4, 57.7.6; Tácito, Anais, 1.75.1.

${ }^{434}$ Tácito, Anais, 3.65.1-2.

${ }^{435}$ Idem, 3.65.3.

${ }^{436}$ Ibidem, 3.65.3.
} 
Augusto, os senadores que acompanhavam Tibério teriam sido representantes permanentes que $\mathrm{o}$ aconselhavam nas tarefas administrativas, e a própria presença deles provavelmente realçou o poder e o prestígio da instituição, o que atribui mais sentido, por exemplo, à afirmação de Veléio Patérculo ${ }^{437}$. Certamente esta organização permitiu a presença cotidiana de Tibério na Cúria e no Fórum, em seus anos em Roma ${ }^{438}$.

Neste contexto, a transferência da responsabilidade das eleições para as magistraturas para o controle do Senado foi uma modificação decisiva. De acordo com Tácito ${ }^{439}$, o Princeps nomeou doze candidatos para assumirem o cargo de pretor, o mesmo número deixado como instrução por Augusto; a despeito da insistência do Senado por um aumento nesta quantidade, Tibério declarou ainda por pacto em assembleia que jamais excederia este número. Em 14 d.C., pouco tempo depois da ascensão de Tibério ao comando imperial, pela primeira vez as eleições foram transferidas do Campo de Marte (Campus Martius) para o Senado: a escolha dos membros mais importantes passou a ser determinada pela vontade do soberano, enquanto a escolha dos magistrados restantes teria ficado sob a predileção da assembleia centuriata ${ }^{440}$.

Neste ínterim, à exceção de alguns poucos rumores, a população não teria reclamado da dispensa desta prerrogativa, enquanto que o Senado, uma vez aliviado da necessidade de angariar votos, consentiu com a mudança, ao passo que de sua parte Tibério se limitou a recomendar não mais do que quatro candidatos. Paralelamente, Veléio Patérculo reporta ${ }^{441}$ que a organização das eleições foi a primeira tarefa de Tibério enquanto Princeps, pelas quais as instruções teriam sido deixadas manuscritas por Augusto.

Sobre a continuidade desta prática, em relação às eleições de 15 d.C. e dos próximos do governo de Tibério, Tácito aponta ${ }^{442}$ para a existência de uma grande diversidade de características para o processo: após remover o nome dos candidatos, Tibério descrevia a linhagem, a vida e a conduta militar de cada um dos indivíduos para que se compreendesse de quem se tratava; ou então suprimia inclusive estes indícios, solicitando aos candidatos que não

\footnotetext{
${ }^{437}$ Conforme exposto acima, 2.126.2-3.

438 LEVICK, 1999, p. 69-70.

439 Tácito, Anais, 1.14.4.

440 Idem, 1.15.1.

${ }^{441}$ Veléio Patérculo, 2.124.3.

442 Tácito, Anais, 1.81.1-2.
} 
corrompessem a eleição por meio de intrigas, pois ele mesmo devotaria estrita atenção para o processo. Além disso, geralmente Tibério pronunciava que anunciaria somente aqueles cujos nomes tivessem sido transmitidos a ele pelos cônsules, embora outros pudessem também registrar a candidatura, caso sentissem confiança em seus méritos ou favorecimento ${ }^{443}$.

Conquanto a interpretação da descrição do processo eleitoral elaborada por Tácito seja bastante obscura, podemos ainda reportar o exame de Dion Cássio sobre este assunto, embora este posicione a sua reflexão sobre os fatos ocorridos durante o ano de 32 d.C.. Em relação aos cônsules, teria sido costume durante o governo de Tibério que estes permanecessem no cargo enquanto este desejasse - alguns podiam ser escolhidos para um longo período, enquanto outros para um período mais curto; alguns eram removidos antes do final do prazo indicado, ao passo que a outros era permitido manter 0 cargo além do previsto ${ }^{444}$.

Mais ainda, Tibério eventualmente indicava um senador para desempenhar o cargo por um ano inteiro e depois o substituía, por vezes restabelecendo um ou até mesmo dois outros cônsules consecutivamente, ou mesmo invertendo a ordem de cônsules designados em sequencia para o cargo $^{445}$. Ao definir tais práticas como irregularidades, Dion Cássio complementa ${ }^{446}$ que estas ocorreram durante todo o seu governo, e no que diz respeito à eleição de senadores para outros cargos, Tibério escolhia quantos ele desejava (diferentemente do apontado por Tácito) e encaminhava-os para o Senado, alguns com recomendação - os quais eram eleitos unanimemente, enquanto outros tinham sua seleção condicionada mediante o mérito de suas pretensões, mediante concordância dos pares ou inclusive por sorteio.

Isto não significa que as eleições deixaram de ser disputadas, mas de fato o povo efetivamente perdera a capacidade de participação - mesmo que relativa - no processo eleitoral. O Senado passou a deter maior autonomia para organizar seus procedimentos no que foi relativo à escolha de seus novos membros e dos eleitos para as magistraturas mais importantes, mas este fato não fora nem uma novidade e tampouco algo exclusivo do Principado de

\footnotetext{
${ }^{443}$ Tácito, Anais, 1.81.2.

${ }^{444}$ Dion Cássio, 58.20.1.

445 Ídem, 58.20.2.

${ }^{446}$ Ibídem, 58.20.3-4.
} 
Tibério. A modificação na estrutura das centúrias votantes com a lei Valeria Cornelia ${ }^{447}$ de 5 d.C. já anunciava esta transformação. Possivelmente esta lei teve também o intuito de conter oponentes políticos do futuro Princeps; a modificação empreendida em 14 d.C. teria sido uma conclusão lógica para evitar a influência de tribunos da plebe ou agitadores influenciando a população, como pode ter ocorrido nos anos entre o exílio de Júlia Augusta, Júlia Menor e Agripa Póstumo.

E ao estabelecer a condução das eleições diante de um grupo menor, com ampla indicação dos candidatos, Tibério passou também a influenciar decisivamente a organização do Senado, não apenas diante do fato de que aqueles que buscavam e dependiam do favorecimento não queriam comprometer sua carreira pela escolha de nomes sem aprovação direta ou indireta do Imperador. Durante o governo de Augusto, sua interferência na escolha dos magistrados dependeu extraoficialmente de sua auctoritas, algo que permaneceu imprescindível. Contudo, a partir do governo de Tibério, o Princeps parece ter adquirido uma posição oficial no processo eleitoral: receber nomes de candidatos e ler publicamente a lista de nome ao Senado quando esta se completasse era uma condição apropriada para neutralizar nomes indesejáveis.

Do mesmo modo, uma vez que as negociações para a escolha de candidatos provavelmente eram um fato corriqueiro sob Augusto, a competição aberta já não fazia muito sentido desde então, o que não significa dizer que ela tenha desaparecido por completo. A participação de Tibério neste processo deve ter continuado a ser sutil, embora fosse difícil o Senado agir em contradição aos prováveis desejos do Princeps, conquanto difícil fosse compreendê-los. Mas mesmo de posse desta influência, os requisitos para o ingresso no Senado e ascensão nos cargos não devem ter sido modificados

\footnotetext{
${ }^{447}$ Esta lei se tornou conhecida pela descoberta da Tabula Hebana de 19 d.C., que inicialmente determinava que senadores e equestres que estivessem formalmente inscritos nas decúrias deveriam votar nos candidatos às magistraturas a partir de uma subdivisão de dez centúrias, cujos nomes foram homenagens aos príncipes Gaio e Lúcio César. Em 19 d.C., os mesmos votantes foram redistribuídos em quinze centúrias, e novamente em vinte centúrias, após a morte de Germânico e Druso César em 23 d.C.. A partir de Augusto, a vinculação a este conjunto de centúrias representou simbolicamente um grande prestígio para estes membros da aristocracia na medida em que também reforçava a importância da casa imperial, uma vez que a configuração relacionou-se às homenagens feitas aos príncipes mortos. Cf. BRUNT, 1961, p. 71-83.
} 
entre Augusto e Tibério, e mesmo antes deste último ascender ao comando: pertencimento a uma família com tradição consular, ou de uma linhagem antiga, talento militar ou diligencia permaneceram fundamentais; os padrões de escolha permaneceram bem previsíveis e, salvo poucas exceções (como Sejano em 31 d.C.), o posto de cônsul continuou reservado a membros das famílias republicanas ou sucessores de cônsules durante o governo de Augusto, uma continuidade dos preceitos republicanos utilizados para 0 propósito da própria manutenção do novo sistema político.

Deste modo, seria imprudente associar o êxito político em uma carreira senatorial como resultado exclusivo da relação com o Princeps, não obstante este grupo ser restrito o bastante para salientar a importância de seus vínculos, e especialmente pelo fato de que homens novos e equestres certamente necessitaram de permissão ou recomendação do Imperador para lançarem-se como candidatos em disputa com os demais jovens aristocratas romanos ${ }^{448}$.

Entretanto, o Princeps sabia que a manutenção de sua posição política dependia de sua preponderância na supervisão deste processo. Tácito reporta $^{449}$ que durante um encontro no Senado, o senador Asínio Galo propusera uma eleição antecipada para o ingresso dos magistrados em seus cargos cinco anos antes do prazo estabelecido, e que os legados das legiões que estivessem encarregados de suas funções antes de serem investidos com a pretura fossem já prédeterminados como futuros detentores do cargo, de modo que o Princeps indicasse doze nomes para cada ano. Sobre o impacto desta proposta, tendo sido os segredos do comando testados, o Princeps respondeu que

recairia pesadamente sobre sua temperança (moderatio) que tantos fossem eleitos e tantos outros fossem dispensados: dificilmente o desgosto era evitado de um ano para o outro, não obstante a proximidade da expectativa confortasse a rejeição; quanto ódio poderia vir daqueles que fossem mantidos em incerteza para além de um quinquênio? Sobre qual base alguém poderia estar apto a prever, em tamanho espaço de tempo, as intenções, a família, a fortuna de cada um? Os

\footnotetext{
${ }^{448}$ LEVICK, 1999, p. 72-4; SEAGER, 2004, p. 105-7.

${ }^{449}$ Tácito, Anais, 2.36.1.
} 
homens se assoberbam mesmo com uma indicação anual; como seria se estes ostentassem o seu cargo por um quinquênio? Além disso, poderia haver uma quintuplicação dos magistrados e um enfraquecimento das leis que estabeleceram os períodos adequados para que os candidatos exercessem sua diligência e para perseguir ou deter condições para a honra do cargo $^{450}$.

Em contrapartida, assegurar a proatividade do Senado não foi algo tão simples. Tibério comunicava-se constantemente com o Senado pessoalmente ou por correspondência, assumindo a dianteira de questões que a ele fossem pertinentes ou por meio de sugestões; esta forma de interação não deixou de existir mesmo após seu afastamento para Capri, mas tornou-se padrão de interação: sua saída de Roma não representou um isolamento político absoluto, e tampouco o abandono da vida pública, não obstante sua ausência do contato cotidiano com os membros da aristocracia tivesse tido um impacto significativo nas interações sociopolíticas neste círculo de poder. Mais ainda, conquanto as intervenções pudessem ter um caráter auxiliar, as mesmas diminuíram de maneira inevitável o prestígio dos senadores.

Um notável exemplo de 15 d.C. evidenciou esta condição e agregou também um indício de um dos principais problemas do governo de Tibério, e a principal razão de sua má-posteridade: a prática indiscriminada das acusações por traição. Vamos abordar isto novamente, embora possamos adiantar que a demonstração de pretensa neutralidade do Imperador, a despeito de seu esforço para evitar o embate direto contra aqueles que o detratavam publicamente, não foi suficiente para assegurar liberdade de expressão ou decisão política, principalmente nestes casos; devemos considerar também que semelhante neutralidade era impraticável, fato sabido pelos acusadores. No que tange ao propósito mais imediato, extraímos um trecho de Tácito, que afirma $^{451}$ que Grânio Marcelo, pretor na Bitínia, fora indiciado por seu questor, Cépio Crispino, por malversação ao Princeps, por ter colocado uma estatua de si mesmo acima da dos demais Césares e por ter decepado uma estátua de

\footnotetext{
450 Tácito, Anais, 2.36.2.

451 Idem, 1.74.1-3.
} 
Augusto, tendo substituído sua cabeça pela de Tibério. Este último fato teria o irritado a ponto de anunciar que se manifestaria sobre a acusação abertamente e mediante juramento, condição que deveria ser seguida pelos demais senadores.

Diante deste impulso, Cneio Pison questionou Tibério se ele votaria em primeiro lugar, pois se fosse o caso, haveria uma opinião a ser seguida; caso contrário, Piso tinha receio de ser imprevidente. O Princeps teria se abalado com tal declaração e falta de cautela, e consequentemente absolvera Grânio Marcelo da acusação por traição ${ }^{452}$. De modo semelhante em 16 d.C., após Tibério ter anunciado que se afastaria por um curto período de Roma, os senadores se questionaram sobre a possibilidade de se fazer um recesso enquanto o Princeps estivesse ausente. Novamente, Cneio Pison propôs que o Senado mantivesse suas deliberações normalmente, condição que traria credibilidade para os senadores e equestres; Asínio Galo, por outro lado, defendeu que quaisquer assuntos discutidos durante a ausência de Tibério pareceriam triviais. Embora este último estivesse de acordo com Pison, teria sido pela garantia do livre debate que o Princeps não interferiria, não obstante o resultado final tenha culminado com 0 adiamento das deliberações senatoriais $^{453}$.

Neste âmbito, o Senado também se valeu inúmeras vezes da possibilidade de se esquivar da tomada de decisões, principalmente na ausência de Tibério. Por exemplo, quando o Princeps encontrava-se na Campânia em 21 d.C. ocorreu uma rebelião na província da África promovida pelo general númida Tacfarinas. Nesta ocasião, Tibério enviara uma correspondência para o Senado informando sobre o caso e solicitando a eles que escolhessem como procônsul alguém que fosse experiente com os afazeres militares, fisicamente apto e capaz de promover uma incursão contra o inimigo. O ex-cônsul Sexto Pompeu (14 d.C.) aproveitou a situação para criticar Mânio Lépido, a quem o primeiro atribuiu incapacidade para governar mesmo a pacífica província da Ásia; a maioria dos senadores teria tido uma posição mais favorável a Lépido, que de fato foi nomeado como governador desta província.

\footnotetext{
${ }^{452}$ Tácito, Anais, 1.74.3-6.

${ }^{453}$ Idem, 2.35.1-2.
} 
Por outro lado, em consideração à província da África, os senadores decidiram que a escolha deveria ser confiada ao próprio Princeps ${ }^{454}$. A réplica de Tibério não tardou a chegar ao Senado: no encontro seguinte, uma correspondência do Princeps conteve simultaneamente uma reprimenda indireta aos senadores por transferirem todo tipo de responsabilidade para ele, bem como a indicação de Mânio Lépido e Júnio Bleso como candidatos para a província da África; a escolha devia ser feita pelos senadores ${ }^{455}$. Ambos foram ouvidos, mas Lépido buscou se desobrigar do cargo por alegar indisposição física, a pouca idade de seus filhos e a necessidade de casar sua filha; todavia ele não teria mencionado o fato de que Bleso era tio de Sejano e, portanto, mais influente.

Tácito alega ${ }^{456}$ a existência deste fator implícito no debate, e o fato de que Bleso também demonstrou relutância, mas sem a mesma convicção de Lépido, e consequentemente foi escolhido por unanimidade. A despeito desta relação - engendrada pelo próprio autor - é possível que tenha havido novamente um insistente interesse de Tibério de fomentar o exercício da autonomia pelo Senado. De fato, a escolha de um associado do Princeps certamente deve ter agradado o Imperador, embora nos pareça que Lépido detinha qualificações para o posto, e deste modo não parece que o debate tenha sido apenas uma farsa ${ }^{457}$.

O Senado se comportou de maneira parecida em outra ocasião. Conforme já havia ocorrido em 16 d.C., a questão da imposição de maiores restrições na extravagância dos banquetes, na posse e utilização de utensílios domésticos e vestimentas da aristocracia da Cidade de Roma foi pauta de acaloradas discussões entre os senadores, não obstante Tibério não tenha interferido na proposição de reforço e intensificação da aplicação da lei sumptuária ${ }^{458}$. Em 22 d.C., o assunto novamente veio à tona. Tácito afirma ${ }^{459}$ que novamente se questionara no Senado a aplicabilidade do rigor contra 0 esbanjamento da aristocracia; seus gastos, realmente grandes, estavam sendo escondidos por uma onda de disfarces nos preços, embora as conversas

\footnotetext{
${ }^{454}$ Ibidem, 3.32.1-2.

${ }^{455}$ Tácito, Anais, 3.35.1-2.

${ }^{456}$ Idem, 3.35.3.

${ }^{457}$ Cf. SEAGER, 2004, p. 110-1.

458 Tácito, Anais, 1.33.1-4; Suetônio, Vida de Tibério, 34.

${ }^{459}$ Tácito, Anais, 3.52.1.
} 
cotidianas dos senadores revelassem a suntuosidade de seus artefatos, e junto disto a preocupação de que um Princeps inspirado na frugalidade dos antigos pudesse intervir com medidas mais severas.

C. Bibulo e outros edis apontaram publicamente que a lei estava sendo desprezada, e que o aumento diário nos preços dos víveres não poderia ser solucionado apenas com medidas convencionais. Os senadores, de sua parte, conduziram a questão de forma intocada para Tibério ${ }^{460}$. Por sua vez, este saudou os edis por terem demonstrado devoção ao seu dever público, mas apontou em correspondência que

em outras ocasiões, padres conscritos, seria mais oportuno se eu estivesse presente para ser questionado e para dizer o que recomendo aos interesses da República [...] de minha parte não é nem honrável permanecer em silêncio e nem fácil ser sincero, pois não é a função de um edil ou a de um cônsul que eu desempenho. Algo maior e mais elevado é requerido de um Princeps; e enquanto o crédito de seus sucessos é arrogado por cada homem para si mesmo, malversação por parte de todos recai sobre apenas $u^{461}$.

As obrigações do Princeps deveriam ser outras. Tácito expõe ${ }^{462}$ que ao final da correspondência Tibério relembrou o Senado de que era seu dever manter o Império unido e assegurar que as províncias fornecessem tudo aquilo do qual a Itália necessitasse, a despeito das constantes ameaças dos ventos e do clima; caso contrário, seria a ruína. Igualmente, se todos os magistrados fossem diligentes o bastante para lidar com a questão, ele seria grato pelo alívio de uma parte deste fardo, mas se a intenção dos debatedores fosse ampliar o problema e deixar a solução em suas mãos, Tibério teria de enfatizar o seu contragosto por querelas, principalmente aquelas que não trariam benefícios nem para ele e nem para ninguém ${ }^{463}$. Ao final da correspondência, 0 Princeps teria isentado os edis de tal responsabilidade; a extravagância dos

\footnotetext{
460 Tácito, Anais, 3.52.2.

461 Idem, 3.53.3.

462 Ibidem, 3.54.4-5.

463 Ibidem, 3.54.6.
} 
banquetes em seus utensílios teria ainda perdurado até o governo de Galba, e consequentemente diminuído nos anos seguintes ${ }^{464}$.

Em termos mais amplos, a discussão sobre a proposição de reforço da lei sumptuária e a maneira com a qual o Senado evitou tomar parte, sempre que possível, em questões delicadas que envolvessem (quase sempre) diretamente os interesses do Princeps, demonstrou simultaneamente a incapacidade do Senado em agir autonomamente e a dificuldade de Tibério em lidar com medidas que pudessem trazer descontentamento aos senadores ${ }^{465}$.

Definitivamente, um equilíbrio na esfera de atuação de ambos não foi algo fácil, mesmo enquanto Tibério permaneceu em Roma participando assiduamente dos assuntos públicos. A fragilidade deste equilíbrio era ainda maior quando as questões envolviam senadores individualmente. Logo no início de seu governo, durante os primeiros encontros com o Senado, após Quinto Hatério ${ }^{466}$ ter questionado por quanto Tibério permitiria a ausência de um soberano no comando, quando o primeiro adentrou no palácio e implorou de joelhos pelo perdão do Princeps, o senador quase foi assassinado por soldados da guarda pretoriana, uma vez que ao aproximar-se de Tibério acidentalmente provocou sua queda. A peculiaridade deste evento não nos impede de usá-lo como exemplo da - delicada - interação entre o Princeps e os senadores, e contraditoriamente em uma provável outra ocasião, Suetônio exemplifica $^{467}$ como Tibério quase excedia os limites da cortesia ao se dirigir aos senadores, tendo o mesmo Quinto Hatério como interlocutor:

Em uma discussão com Quinto Hatério no Senado, ele disse: "eu imploro o seu perdão, se em minha qualidade como senador eu uso uma linguagem demasiado livre me opondo a você". E então se dirigindo a todos os demais: "eu digo agora e tenho dito até então, padres conscritos, que um princeps bem disposto e útil, a quem vocês têm dado tamanho e irrestrito poder, deve ser servo do Senado, geralmente dos cidadãos como um todo, e às vezes inclusive de indivíduos privados. Eu

\footnotetext{
464 Tácito, Anais, 3.55.1.

465 LEVICK, 1999, p. 143.

${ }^{466}$ Cf. Tácito, Anais, 1.13.6; Suetônio, Vida de Tibério, 27.

467 Suetônio, Vida de Tibério, 29.
} 
não me arrependo de minhas palavras, mas eu tenho me dirigido a vocês como amáveis, justos e indulgentes senhores, e ainda assim vos considero".

A família imperial também não auxiliava Tibério nesta tarefa. Em 16 d.C., L. Calpúrnio Pison, irmão do condenado Gneio Pison, proferiu uma severa crítica sobre a corrupção no Fórum e o abuso dos acusadores, tendo concluído com a intenção de abandonar a vida pública e se retirar para um refúgio no campo, e imediatamente saído da Cúria senatorial. Tibério teria se abalado de tal forma que, a despeito de suas súplicas para que reconsiderasse, compeliu os amigos de Pison a impedi-lo de levar adiante suas intenções, mediante sua influência direta e apelos pessoais ${ }^{468}$.

Por outro lado, à indignação de Pison seguiu-se sua acusação contra Urgulânia, amiga íntima de Lívia, que ignorou a convocação dos senadores e dirigiu-se pessoalmente a Tibério. Uma vez que Pison insistiu para que ela fosse à corte, de sua parte Lívia - que era favorável aos apelos de Urgulânia reclamou que seu prestígio estava sendo violado, o que teria compelido Tibério a prometer que intercederia pessoalmente por ela no tribunal. Em contrapartida, certo das razões de Pison, Tibério demorou o máximo possível para chegar ao tribunal - tática que se provou efetiva, pois foi tempo suficiente para que Lívia pudesse pagar a fiança de Urgulânia.

Contudo, não muito depois Urgulânia novamente se envolveu em outra acusação, e tendo se recusado a comparecer à convocação dos senadores, obrigara um pretor a tomar o seu testemunho em sua residência, algo que jamais havia acontecido na história do Senado, mesmo com virgens vestais ${ }^{469}$. Posto isso, o próprio prestígio e a influência do Imperador e de seus familiares para com membros próximos à corte imperial, um elemento natural à estrutura do poder imperial, tornou-se cada vez mais um fator complicador para a relação entre o Princeps e o Senado.

Ao passo que, com Tibério em Roma, seu esforço primordial tivesse sido o de assegurar que o controle das deliberações senatoriais ficasse a cargo de seus próprios membros, era de seu interesse - acima de tudo - demonstrar

\footnotetext{
${ }^{468}$ Tácito, Anais, 2.34.1.

${ }^{469}$ Idem, 2.34.2-4.
} 
que mesmo as magistraturas menores possuíam o seu escopo de atuação bem definido. No entanto, os exemplos acima demonstraram que entre esta intenção e suas atitudes haviam obstáculos ocasionados, primordialmente, pela própria natureza do sistema político do Principado, ainda em experimentação e, além disso, pelo próprio posicionamento dos senadores em relação ao Princeps: ninguém queria arriscar sua carreira desagradando o soberano, e dificilmente os primeiros detinham a mesma motivação republicana de defesa da liberdade de expressão, em um contexto que, desde Augusto, em termos práticos centralizou a instância máxima de decisão na autoridade do Imperador. Neste sentido, e no âmbito da rotina das interações entre Princeps e Senado, Tibério demonstrou bastante preocupação com a administração das leis, sendo que os procedimentos cotidianos dos senadores caracterizar-se-ão gradualmente como uma fonte de observação, deliberação e aplicação das mesmas. O problema, ainda com a presença de Tibério em Roma, seria o estabelecimento de um equilíbrio entre o limite da possibilidade de interferência do Princeps e os interesses naturais da aristocracia senatorial por promoção política individual na elaboração e na aplicação das leis. O crime de traição demonstrou ser um exemplo claro da instabilidade desta relação. 


\section{3 - Tibério e o Senado: os problemas na aplicação da lei de traição (Lex Iulia de Majestatis)}

Como pudemos observar até o presente momento, Tibério demonstrou durante os primeiros anos de governo um frequente interesse pela participação nas deliberações administrativas e jurídicas cotidianas na Cidade de Roma, estando ou não presente na capital do Império. Certamente, conquanto sua ascensão tenha sido tumultuada pelas discussões acerca de sua relação com os poderes herdados de Augusto, e do mesmo modo a relação da abrangência destes poderes com a esfera de atuação do Senado como instituição e de seus membros, a presença do Princeps, na prática um empecilho contra demonstrações de livres manifestações de liberdade e expressão políticas nos moldes de outrora, ainda sim representou uma baliza, ou mesmo um referencial para a atuação individual dos senadores, principalmente se considerarmos estes cidadãos em sua perene busca por ascensão e satisfação de interesses pessoais específicos, fortemente vinculados ao êxito na carreira pública, e na manutenção de seu status e riqueza.

De uma maneira geral, as leis teriam sido bem administradas durante este período: esta foi a constatação de Tácito ${ }^{470}$. Por outro lado, o mesmo afirma ${ }^{471}$ que, a despeito de ter recusado no início de 15 d.C. o título de "pai da pátria" e o juramento de obediência às suas ações pelo Senado - fatos que por princípio teriam contribuído para enfatizar sua civilitas (entendido aqui como uma maneira de portar-se como um entre os iguais), a crença nesta impressão teria sido desmantelada pelo fato de Tibério ter revivido a lei de traição (lex maiestatis). Tácito complementa que esta lei mantivera a mesma denominação de outrora, mas que até então diferentes questões eram conduzidas à corte, como incitar um exército ou a plebe à sedição ou ameaçar a soberania do povo romano por má-administração. Augusto teria sido o primeiro a inserir documentos difamatórios dentro da categoria de causas condenáveis sob esta lei: os escritos de Cássio Severo infamando homens e mulheres ilustres teriam

\footnotetext{
470 Tácito, Anais, 4.6.1.

${ }^{471}$ Idem, 1.71.2.
} 
causado a ira deste Princeps $^{472}$ (tendo sido o primeiro exilado entre 8 ou 12 d.C.).

Anos mais tarde, quando consultado pelo pretor Pompeu Macer sobre quais procedimentos poderiam ser permitidos em casos de traição, Tibério teria respondido que as leis deveriam ser cumpridas ${ }^{473}$. Esta passagem apresenta um equívoco: a lei de traição não havia sido suspensa ou repelida durante o governo de Augusto, e Tibério, ao responder que esta, bem como provavelmente todas as demais leis fossem cumpridas, simplesmente teria reafirmado uma dada situação. Em verdade, a razão deste questionamento feito pelo pretor nos parece obscura, da mesma forma como a resposta do Princeps um tanto óbvia: a manutenção de preceitos republicanos. Contudo, o que se viu em sequência é que o escopo desta lei - entre inúmeros elementos de origem republicana - adquiriu uma nova significação durante o Principado, e que a proeminência de acusações, perseguições e condenações a membros da aristocracia senatorial tornou-se um aspecto bastante valorizado para uma posterior avaliação negativa do governo de Tibério $^{474}$.

O crime de traição à majestade possuiu raízes mais profundas. Possivelmente desde o período monárquico o crime de alta traição (perduellio) referiu-se a qualquer tipo de ofensa que ameaçasse - somada ou não a outras infrações - à majestade e soberania da res publica, e já se fazia presente na Lei das Doze Tábuas. A ideia de "majestade do povo romano" (maiestas populi romani) é tão antiga e complexa como os outros valores que compuseram o ideário republicano desde seu início (conforme já pudemos observar em termos como res publica ou populi romani), o que poderia significar tanto a pena de morte quanto o pagamento de multas ao erário; um crime à majestade (crimen maiestatis) poderia inclusive ser cometido por cidadãos sem cidadania romana e fora dos limites provinciais.

\footnotetext{
472 Dion Cássio, 56.27.1; Tácito, Anais, 1.71.2-3. Sobre Cássio Severo, Tácito aponta mais adiante (Anais, 4.21.3) que, a despeito de uma origem ignóbil e uma vida de intempéries, era um hábil orador e mediante os seus irrestritos antagonismos assegurara seu banimento para a ilha de Creta mediante veredito do Senado. Contudo, mesmo exilado Cássio Severo teria continuado a tecer imprecações e, tendo seus bens confiscados e proibido de voltar a Roma, envelheceu no rochedo de Serifos. Portanto, teria sido um personagem recorrente em polêmicas e acusações durante os governos de Augusto e Tibério.

${ }^{473}$ Tácito, Anais, 1.72.4.

${ }^{474}$ LEVICK, 1999, p. 144; SEAGER, 2005, p. 126-7.
} 
Contudo, sua primeira aplicação específica é reconhecida com a lex Appuleia, cujo intuito era a condenação daqueles que maculassem a majestade do povo romano, e que havia sido introduzida mediante proposição do tribuno L. Apuleio Saturnino ao final do século II a.C. (provavelmente promulgada em seu primeiro tribunado, no ano de 103); seu escopo abarcava sedição, incompetência militar e mobilização do exército sem autorização do Senado.

Embora não saibamos qual fora a penalidade prescrita pela lei possivelmente teria sido a morte, embora o exílio voluntário tenha sido uma constante no que tange a estes crimes - a proposição de Saturnino substituiu a realização de julgamentos que contavam com membros da assembleia popular por outra corte responsável pelas apurações (quaestiones), constituída exclusivamente por equestres. Consequentemente, a prática de comprovação da acusação de um réu por um crime de traição deixou de ser uma prerrogativa deste processo-crime, uma vez que, da simples tarefa do tribuno em comprovar a culpa do acusado em meio a inúmeras outras tarefas de seu cargo, criou-se uma corte específica para a análise dos mesmos.

Entretanto, desde o início de sua aplicação, o escopo de acusações que podiam ser consideradas como traição à majestade foi muito amplo; a natureza do crime fez com que sua condenação se tornasse uma peculiar ferramenta de eliminação política, e principalmente durante o final do período republicano, a aplicação desta lei era frequentemente criticada como, por exemplo, nos escritos de Cícero $^{475}$. A diminuição da majestade (maiestas minuta) do povo romano, em decorrência de sua amplitude, foi interpretada de acordo com a referência de preservação da majestade e soberania do segmento social que de fato deveria exercer o poder em Roma, e para Saturnino, deveria ser (ao menos no discurso) o povo. Com sua morte e a de seus associados imediatamente ao final de seu tribunado, a majestade retorna para o prestígio do Senado e para a responsabilidade dos pretores.

A grande mudança veio com Lúcio Cornélio Sula. Diante do precedente estabelecido por Saturnino, a antiga noção de perduellionis (atentar contra a majestade do povo romano), foi associada aos elementos específicos elencados pelo tribuno da plebe, e a combinação de ambos culminou com a

${ }^{475}$ Cícero, Epístola aos Familiares, 3.11.3. 
Lex Cornelia de maiestate. Provavelmente a sentença de morte teria sido a pena oficial para os casos de traição, mas não se observa elementos que demonstrem que de fato a punição capital foi empreendida desde então; a inevitabilidade da morte permitia o exílio, e tornou-se comum a proibição de retorno ao solo italiano (interdictio aquae et ignis), a exclusão da cidadania romana (com a possibilidade de adoção de outra), não obstante sem menções à confiscações de bens ou condenação da memória (damnatio memoriae) do culpado.

Em perspectiva, vários fatores provavelmente explicam esta transformação: o crescimento da população trouxe o aumento no número de criminosos, e deste modo uma maior necessidade de remoção permanente destes do cotidiano; por outro lado, a restauração de estabilidade social, política e militar pode ter significado maiores expectativas quanto à repressão do crime. Mais importante, a partir de Augusto, na Cidade de Roma o Senado e o prefeito urbano exerceram uma nova jurisdição criminal, e nas províncias o papel do governador tornou-se gradualmente mais judicial e menos militar (iudex tornou-se uma designação comum).

Advinda em última instância do Imperador, as novas cortes deliberativas do Principado não se restringiram às penalidades depositadas aos estatutos de cada ordem social, mas tiveram liberdade para mitigar ou intensificar as penalidades pré-estabelecidas. Junto da execução, o suicídio, sugerido pelos imperadores ou escolhido pelos próprios senadores, foi um destino comum para os senadores durante o início do Principado, pois representava uma morte sem a perda da dignitas e, sobretudo, sem consequências mais desastrosas para os familiares remanescentes: geralmente o suicídio evitava a confiscação dos bens pelos acusadores e mantinha o nome dos mesmos no fasti. A deportação - de caráter vitalício - era uma sentença capital que envolvia a perda da cidadania e a confiscação total dos bens do condenado.

O ostracismo (relegatio) por sua vez poderia ser perpétuo, mas frequentemente era fixado por um período determinado, e acompanhado de uma confiscação parcial. Consequentemente, este teria sido o legado jurídico transmitido ao Principado, com a possibilidade de ampliação de seu escopo às novas experimentações políticas que viriam a partir de Augusto e seus sucessores: a majestade do povo romano também seria a majestade do 
Princeps com sua família e associados e o Senado, cuja supremacia e prestígio político foram preocupações manifestadas tanto pelo primeiro quanto por Tibério ${ }^{476}$. Posteriormente, o crime contra a majestade tornou-se praticamente qualquer crime contra o Estado e o Imperador 477 .

Contudo, o resultado do julgamento de Marco Primo e o envolvimento de Licínio Murena e Fânio Cépio, que contou com a participação de Tibério tendo como destaque suas habilidades oratórias, já havia inaugurado um complicado precedente durante a primeira década do governo de Augusto. A ampliação da aplicação perceptível com a Lex lulia de maiestatis certamente originou-se no quadro das reformas empreendidas por Augusto, não obstante nos faltem os termos precisos da lei, e suas referencias sejam tardias. Em contrapartida, parece claro que inicialmente os termos da punição mantiveram-se essencialmente baseados no exílio dos condenados; as mortes de Murena, Primo, Cépio, lulo Antônio são incertas, mas não foram punições capitais. É certo que, a partir de 23 a.C., a existência do consilium principis relacionou-se também com a transferência da condução dos casos de traição para a supervisão dos cônsules.

A participação do Senado no julgamento e condenações destes senadores por traição e conspiração contra a res publica provavelmente desvelou o estabelecimento da concentração da análise e julgamento destes crimes dentro do próprio Senado, uma vez que a majestade, a manutenção da segurança e bem-estar passou a ser vinculada essencialmente aos membros da própria ordem senatorial. Embora aparentemente esta autonomia jurídica fosse benéfica por permitir aos senadores o restabelecimento do controle sobre a condução da atuação política de seus pares principalmente na administração das províncias, consequentemente os mesmos tornaram-se mantenedores da majestade do povo romano e seus magistrados, e igualmente do próprio Princeps.

Mais ainda, os senadores não poderiam empreender julgamentos sem a manifestação aberta de suas opiniões e, evidentemente, a discussão sobre as razões e provas que eventualmente condenariam um acusado. Como nas

\footnotetext{
${ }^{476}$ CHILTON, 1955, p. 73-5; FERRARY, 1983, p. 570-2; LEVICK, 1999, p. 145; ROBINSON, 2007, p. 187-90.

477 Digesto apud BERGER, 1953, p. 418, 626.
} 
demais deliberações políticas, as opiniões de um senador estariam visíveis ao Princeps, bem como a seus associados; é importante relembrarmos que o Senado não foi, em nenhum momento de sua história, um corpo político homogêneo, e consequentemente a carreira política (ou mesmo a vida) de um senador dependia fortemente de seu posicionamento.

Podemos observar uma característica que se manifesta a partir de então e que é evidente durante o governo de Tibério: a irregularidade na maneira como os diversos casos serão conduzidos pelo Senado, com ou sem uma interferência explícita do Princeps. Richard Bauman ${ }^{478}$ afirma que um fator primordial para que as acusações e condenações passassem a irromper desta forma relacionou-se à renúncia formal da amizade entre o Princeps e um potencial acusado (renuntiatio amicitiae). Uma vez que a preservação da majestade relacionou-se gradualmente à pessoa do Imperador e à divindade de Augusto, o limite entre a quebra de laços pessoais como resposta à ofensa e a criminalização da ofensa como injúria ao próprio Estado tornaram-se cada vez mais tênues.

Ademais, Tibério parece ter conseguido - em seus primeiros anos, até o momento em que a influência de Sejano torna-se latente - sublimar a ambivalência desta relação quando ofensas contra ele, membros da família imperial ou Augusto foram delatadas. Contudo, esse panorama começa a se transformar a partir de 23 d.C. (e observa-se um ápice entre 32 e 35 d.C., com o método de acusação tendo sido reiterado por Macro), na medida em que as fontes passam a dedicar maior atenção à ascensão de Sejano. Assim, o que se observa é que, no que diz respeito ao crime de traição, a aplicação das leis durante o Principado apresentaram um grau de flexibilidade e engenhosidade que fez dessa forma de acusação um amplo instrumento de repressão que caminhou paralelamente ao desenvolvimento deste sistema político: uma fusão entre a renúncia pessoal da amizade com a possibilidade de crime contra a majestade, e da mesma maneira tornar-se inimigo do Princeps passou a representar hostilidade ao povo romano ${ }^{479}$.

Nesse contexto, o Senado como corte começou a ir além da penalidade prescrita na lei. Embora não possamos comprovar se a condução dos casos,

\footnotetext{
${ }^{478}$ 1971, p. $110-13$.

${ }^{479}$ BAUMAN, 1971, p. 225-7.
} 
especialmente com a supervisão dos cônsules, veio acompanhada de uma prerrogativa que permitia ampliar as punições para além do estabelecido, é provável que as cortes de justiça organizadas dentro do próprio Senado passaram a ter um interesse evidente em agraciar o Princeps pela intensificação das penalidades, sobretudo em casos em que sua pessoa ou a família imperial estivesse envolvida; a prática tornou-se então praticamente uma regra, e o banimento e as execuções começaram a ser mais sumárias e cada vez mais comuns durante o Principado ${ }^{480}$.

Alguns exemplos são basilares para tanto. O primeiro, especialmente por ter sido a primeira menção sobre a acusação por traição durante 0 Principado de Tibério é citado emblematicamente por Tácito ${ }^{481}$ : durante 0 ano de 15 d.C., os equestres Falânio e Rúbrio foram acusados, o primeiro por ter admitido um ator (um certo Cássio) em meio aos responsáveis pelo culto doméstico a Augusto, e pela venda de seu jardim junto de uma estátua do falecido Princeps; Rúbrio teria perjurado contra sua divindade. E ambos foram absolvidos por Tibério: o primeiro por ter conhecido o mencionado ator de representações em festividades que sua mãe Lívia dedicava a Augusto, e o segundo por determinar que o perjúrio ao falecido Imperador fosse semelhante ao perjúrio a Júpiter: as injúrias aos deuses eram preocupações dos próprios deuses $^{482}$.

Outro caso, contudo, melhor demonstra como a possibilidade de eliminação política tornou-se um mote para as acusações. Ainda no mesmo ano, o senador Grânio Marcelo, no momento pretor da província da Bitínia, foi acusado de traição por seu questor Cépio Crispino, e apoiado pelo testemunho de Hispo Romano. Grânio Marcelo teria tecido anedotas sobre Tibério, teria colocado sua própria estátua em um patamar mais alto do que a dos Césares, e também degolado uma estátua de Augusto, pondo a de Tibério em seu lugar $^{483}$. Na ocasião, Tibério teria se irritado a ponto de anunciar publicamente e por meio de um juramento sua opinião, condição que também seria imposta aos demais magistrados.

\footnotetext{
${ }^{480}$ CHILTON, 1955, p. 75; LEVICK, 1999, p. 146.

481 Tácito, Anais, 1.73.1-2.

482 Idem, 1.73.4.

483 Ibidem, 1.74.1-3.
} 
Nesse ínterim, a inesperada reação do Princeps provocou outra ainda mais embaraçosa; o senador Gneio Pison argumentou que necessário saber como Tibério se manifestaria: se fosse o primeiro a falar, o senador teria um referencial a seguir, mas se fosse por último, era temível se mostrar contrário ao Imperador. O impacto deste questionamento teria provocado por fim a absolvição das acusações por traição referentes a esse caso ${ }^{484}$. Possivelmente o Princeps teria se irritado mais pela repetição de uma maliciosa tentativa de incriminação - a despeito da postura adotada no caso anterior -, e pelo fato de o perjúrio à memória de Augusto e a difamação de sua própria pessoa ter sido percebida como uma tentativa de constrangimento por uma finalidade escusa dos acusadores; a reação final de Tibério nesta ocasião pode ter sido um duro golpe em seus preceitos políticos, uma vez que a licenciosidade dos acusadores viera da mesma fonte: o estímulo à autonomia e à liberdade de expressão política senatorial ${ }^{485}$.

A já mencionada conspiração promovida por Marco Escribônio Libo Druso, no ano de 16 d.C., pode ser considerada o primeiro caso de condenação por traição do governo de Tibério, pelo fato de ter estado mais próximo do sentido conceitual deste crime: uma notória ameaça à res publica. A gravidade das acusações acabou por impelir um excesso de decretos senatoriais que visaram transmitir a impressão de que estes poderiam surtir um efeito positivo diante da perspectiva que certos senadores teriam tido de demonstrar sua lealdade ao Imperador.

Do mesmo modo, o relato mais detalhado de Tácito transparece a impressão de que o semblante de impunidade diante da audácia dos acusadores teria promovido a manutenção desta forma de conduta, e paralelamente a imparcialidade de Tibério teria pendido para a ideia de que 0 Senado pudesse ser uma corte judicial imparcial e autônoma. Neste sentido, acreditamos que o posicionamento de Tácito propõe, por conseguinte, que isto não ocorreu justamente pelo oportunismo criado com a prática da delação e por uma conduta equivocada - embora não perniciosamente maliciosa - do Princeps: Tibério não tenha mensurado cautelosamente a tendência corrosiva da delação dos acusadores (delatores) sob uma parte da aristocracia romana,

\footnotetext{
${ }^{484}$ Tácito, Anais, 1.74.5-6.

${ }^{485}$ LEVICK, 1999, p.; SEAGER, 2005, p. 128.
} 
condição que pareceu fundamental para o julgamento histórico de Tácito ${ }^{486}$, por exemplo.

Com o passar dos anos, a prática da delação tornou-se cada vez mais vantajosa para membros da aristocracia senatorial enquanto artifício de eliminação política e enriquecimento, e neste quesito o caso de Clutório Prisco é, sem dúvida, um dos mais importantes. Deste modo, durante o ano de 21 d.C. Prisco, um equestre que havia sido agraciado com uma soma em dinheiro após a publicação de um poema amplamente divulgado em que lamentava os momentos finais de Germânico César no ano de 19 d.C., foi atacado por um delator que lhe imputou a acusação de que, durante a enfermidade de Druso Cláudio, Clutório Prisco havia composto algo que poderia ser publicado mediante uma recompensa ainda maior caso a vida do príncipe se extinguisse; os versos teriam sido lidos na residência de P. Petrônio (cônsul suffectus no ano de 19 d.C. e sogro do futuro Imperador Vitélio), na presença de sua sogra Vitélia e muitas matronas ilustres.

Prisco fora sentenciado com a pena capital pelo senador e cônsul designado Hatério Agripa ${ }^{487}$. Com Tibério ausente de Roma (o Princeps encontrava-se na Campânia) em assembléia, o senador Mânio Lépido opuserase à severidade de tal medida e sugerira que Prisco fosse banido de Roma, apelando à moderação do Princeps, e que o acusado apenas tivesse seus bens confiscados e fosse exilado, como alguém sujeito à lei de traição ${ }^{488}$. Apenas o ex-cônsul Rubélio Blando teria concordado com esta penalização, enquanto o restante dos senadores seguiu a proposição de Hatério Agripa: Prisco foi imediatamente conduzido para a prisão e executado ${ }^{489}$. Entretanto, a

\footnotetext{
${ }^{486}$ SHOTTER, 1972, p. 97-8. Embora tenhamos relacionado as narrativas sobre o caso presentes em Dion Cássio, Suetônio e Tácito, a nosso ver, a importância do relato de Dion Cássio consiste na atribuição de certa inconsistência entre a punição recebida por Libo Druso e a absolvição do senador Víbio Rufo. Mais especificamente, Dion Cássio relata (57.15.6-7) que Tibério não impôs nenhuma acusação contra este, que costumava sentar-se na mesma cadeira usada por Júlio César e onde fora assassinado: valendo-se desta prática e do fato de ter se casado com a viúva de Cícero, Víbio Rufo costumava vangloriar-se ao dizer que se tornaria um grande orador por conta de sua esposa ou um César por conta de sua cadeira. A comparação feita entre os casos de Libo Druso e Víbio Rufo, embora seja contraditória com a própria afirmação feita pelo autor (57.9.3) do grande esforço de Tibério em tomar parte de acusações ou insultos sobre sua própria pessoa ou a família imperial nos auxilia a corroborar a grande disparidade das intervenções senatoriais e a moderação (moderatio) do Princeps na administração da justiça, especialmente em relação aos crimes de traição.

${ }_{487}^{48}$ Tácito, Anais, 3.49.1-2.

${ }^{488}$ Idem, 3.50.4.

${ }^{489}$ Ibidem, 3.51.1-2.
} 
condução do julgamento fora censurada por Tibério - embora sem críticas a Mânio Lépido e Agripa - e logo em seguida o Senado aprovou um decreto estipulando as condenações não fossem encaminhadas antes de dez dias, prazo que deveria ser permitido ao condenado antes da execução ${ }^{490}$.

Embora não saibamos quais foram os desdobramentos posteriores, podemos supor que os acusadores tiveram acesso à parte dos bens confiscados (um terço do patrimônio do condenado). O caso de Prisco exemplificou simultaneamente a ausência de uma salvaguarda que impedia julgamentos precipitados até então, e demonstrou mais uma vez o interesse deliberado de senadores pela obtenção de benefícios financeiros por meio das confiscações $^{491}$. Mais ainda, a pressa com que o Senado julgou o caso - sem ouvir o Princeps, particularmente interessado nas questões jurídicas promovendo intervenções nas leis poderia se tornar (e de fato se tornou) algo perigoso; porém, uma interferência mais enérgica no caso teria infringido o princípio de fazer dos senadores soberanos em sua instituição ${ }^{492}$.

A preocupação com as leis, e por outro lado a maneira como a diminuição da majestade imperial passou a ser vinculada como garantia para o agravamento das condições de um acusado aparece no ano seguinte, embora desta vez com um desfecho diferente. Em 22 d.C. Gaio Silano, procônsul da província da Ásia, foi acusado de extorsão (repetundae) pelos provinciais ${ }^{493}$. 0 caso foi agravado pelas denúncias simultâneas do ex-cônsul Mamerco Escauro, o pretor Júnio Othon, e o edil Brutédio Nigro, que haviam lhe conferido a acusação de perjúrio por violação de uma imagem de Augusto e escárnio da majestade de Tibério ${ }^{494}$.

Nesse ínterim, o número de acusadores acresceu com Gélio Publícola e Marco Pacônio, respectivamente questor e legado de Gaio Silano. Tácito

\footnotetext{
${ }^{490}$ Dion Cássio, 57.20.3; Tácito, Anais, 4.51.2.

491 Que estas intenções tornaram-se um condicionante quase permanente nos diversos casos de condenação por traição citados por Tácito é dedutível pelo relato da condenação de Sexto Mário e Pompônio Labeo (Tácito, Anais, 6.19.1; 6.29.2).

${ }^{492}$ LEVICK, 1999, p. 147; SEAGER, 2005, p. 134.

${ }^{493}$ Como será observado nas páginas seguintes, o caso de Silano é um dos vários em que envolveram acusações de extorsão por parte dos governadores de províncias. Em relação à rigidez do controle do comportamento dos governadores de província, Dion Cássio (57. 10.5) menciona o caso do governador Emílio Recto, que ao enviar da província do Egito uma soma de dinheiro maior do que a estipulada, recebeu em retorno uma mensagem de Tibério que desejava suas ovelhas tosquiadas, não escalpeladas.

${ }^{494}$ Tácito, Anais, 3.66.1.
} 
afirma ${ }^{495}$ que o acusado era culpado em relação à crueldade e a malversação; em meio a uma injunção de advogados, Tibério teria permitido novamente o escrutínio dos escravos por meio da tortura, e uma vez que nenhum associado intercedera em favor de Silano, este último requisitou alguns dias de intervalo para elaboração de sua defesa ${ }^{496}$. Tibério relacionara a gravidade do caso de Silano ao fazer uma analogia à condenação de Lúcio Valério Messala Voleso, também procônsul da Ásia durante o governo de Augusto (12 d.C.). Feito isto, Tibério demandou a opinião do senador Lúcio Pison, que de sua parte opinou pelo exílio do acusado, o que foi seguido pelo restante dos senadores ${ }^{497}$.

Além da já notada preocupação de Tibério em se fazer presente e refletir sobre o papel deliberativo do Senado, temos aqui o indício de um problema que se agravou com o afastamento do Princeps para Capri: a tenuidade da linha divisória entre a autoridade do Princeps e a autonomia e prestígio do Senado, e principalmente a inconsistência na postura de Tibério como um efeito colateral de seu zelo pela preservação da instituição, pois além de não observarmos um procedimento estritamente formal na análise dos casos julgados no Senado, o Princeps demonstrou reações diversas quando presente nos julgamentos, algo que abriu ainda mais brechas para intensificação das condenações a partir de seu afastamento.

Três exemplos confirmam esta proposição. Após tecer críticas ao comportamento de Silano em seu cargo de governador da província, Cornélio Dolabela propôs a Tibério que homens de vida infame não fossem elegíveis para o posto, e que a decisão ficasse nas mãos do Imperador $^{498}$. Tibério declinou desta iniciativa, tendo alegado que não era possível para um Princeps abarcar todas as coisas sob o seu conhecimento, e tampouco desejável que o mesmo fosse influenciado pelas intrigas de outros; onde fosse possível proceder pela forma da lei seria um erro empregar a sanção do soberano ${ }^{499}$.

Cremos ser legítima a preocupação de Tibério em não interferir diretamente na escolha dos magistrados para as províncias senatoriais, mesmo diante do fato de que a maior parte dos governadores permanecia em seus

\footnotetext{
${ }^{495}$ Idem, 3.67.1.

${ }^{496}$ Tácito, Anais, 3.67.4.

${ }^{497}$ Idem, 3.68.2.

498 Ibidem, 3.69.1.

499 Ibidem, 3.69.3-4.
} 
cargos durante anos a fio, uma evidência da necessidade que surgiu a partir do Principado de o soberano contar com associados políticos confiáveis na administração provincial e, principalmente, no controle das legiões. Contudo, esta necessidade pragmática depôs contra uma postura mais enérgica em relação aos usos da prática denunciatória. Ainda em 22 d.C., Lúcio Ênio, um equestre, foi indiciado por traição diante da acusação de ter fundido uma estatueta de Tibério para a confecção de prataria. O Princeps proibiu a elaboração de um processo, embora o senador Ateio Capito tenha protestado que o direito de decisão não deveria ser usurpado do Senado, e tampouco semelhante ofensa passar sem punição; Tibério persistiu no veto por ter percebido as intenções implícitas na fala do Senador ${ }^{500}$.

Por último, em 25 d.C. Cremúcio Cordo foi indiciado sob a acusação de ter publicado anais e feito elogios a Bruto e Cássio como os últimos verdadeiros romanos. Os acusadores foram Sátrio Segundo e Pinário Nata, clientes de Sejano, e diante da recepção acrimoniosa do Princeps em relação às duras invectivas pronunciadas durante a apreciação do caso no Senado Cremúcio Cordo cometeu suicídio, embora cópias de sua obra tenham sobrevivido para a posteridade ${ }^{501}$. Em contrapartida, tal infortúnio não acometeu o senador Gaio Fonteio Capito, cônsul no ano de 12 d.C. e provável procônsul da Ásia entre 23 e 24 d.C., pois neste caso Fonteio foi inocentado de acusações fabricadas contra ele pelo senador Víbio Sereno ${ }^{502}$.

À exceção da condenação de Cremúcio Cordo, estas são as principais menções ao comportamento de Tibério e do Senado em relação à intensificação das acusações por traição anteriores à morte de Druso Cláudio. Provavelmente ocorreram inúmeras outras que não são mencionadas na documentação, principalmente por Tácito, uma vez que o critério de seleção deste autor apresentou um interesse específico: o crescimento da presença dos acusadores, a gradual extensão da lei a outros critérios diferentes de suas primeiras manifestações de aplicação, e o fato de que a maior parte dos acusados foram proeminentes senadores e equestres, em casos cuja

\footnotetext{
${ }^{500}$ Dion Cássio, 57.23.4; Tácito, Anais, 3.70.2.

501 Tácito, Anais, 4.34.1, 35.4-5.

${ }^{502}$ Idem, 4.36.2.
} 
participação do Imperador é particularmente notável e útil para a composição da caracterização do Princeps.

A despeito do questionamento feito por Pompeu Macer sobre a aplicação da lei, o que observamos durante os primeiros anos do governo de Tibério foi que a administração da mesma ficou majoritariamente a cargo do Senado, conquanto a instância final de julgamento residisse no consentimento do Imperador. Porquanto durante o início do Principado a legislação senatorial tenha tomado a forma de recomendações aos magistrados na interpretação das leis existentes, já durante o governo de Tibério parte das discussões legislativas resultou, mais do que no banimento ou retificação de uma ou outra lei, em esclarecimentos sobre jurisprudência, impressão transmitida pela documentação aqui apresentada, em que observamos um cotidiano de frequentes debates sobre a compreensão destas leis. Esta caracterização proveio de Augusto, e não é por acaso que Tibério se cercará de filósofos e outros indivíduos versados em leis na sua corte em Capri: o conhecimento das leis possivelmente foi um tema relevante e de perene interesse para este Imperador, algo perceptível em sua frequente participação no Fórum e nas assembleias.

Evidentemente, as deliberações sobre as leis visavam - especialmente no que tangeu à aplicação das condenações por traição e no ambiente do Fórum - os interesses individuais dos senadores e de seus associados políticos, e é possível que a primeira menção sobre esta lei tenha advindo de algum apuro vivido por um equestre ou senador neste contexto. O que é mais importante, a aplicabilidade da lei de traição - estimulada pelos interesses ou temores na ação dos acusadores - representou a mais relevante tentativa de se modificar as leis durante o governo de Tibério. A condução dos julgamentos dentro do Senado trouxe uma possibilidade de controle político ao Princeps semelhante à transferência das eleições para as magistraturas em 14 d.C.; os casos mais importantes certamente foram aqueles que afetavam diretamente a majestade do Imperador.

Igualmente, relacionados o adultério e a extorsão aos crimes de traição, a posição desta corte de justiça presente no Senado tornou-se gradualmente mais ostensiva, e enquanto Tibério esteve presente em Roma tentara conduzir a situação preservando a autonomia do Senado e a conciliação com aquilo que 
pensava ser a melhor forma de administração da justiça. E como era impossível averiguar uma denúncia antes de sua exposição pública, o que poderia ser feito era checar particularmente a veracidade ou absurdo de cada caso; os exemplos demonstram que isto não deu certo, a despeito da presença de Tibério, e já antes de seu afastamento: observamos a avidez dos acusadores e seus informantes em explorar as denúncias em benefício próprio, a relutância de familiares e amigos em apoiar acusados por medo de cumplicidade, e a prontidão de senadores em não apenas condenar, mas também extrapolar a interpretação e as consequências das leis. A abolição da lei também não teria sido uma alternativa: a tentativa de angariar popularidade pretendida por Gaio César diante dessa iniciativa durou apenas dois anos; a condenação por traição voltou à tona em Cláudio e Nero, e em larga medida o temor da condenação era uma proteção do Princeps contra tentativas de conspiração e assassinato ${ }^{503}$.

$\mathrm{O}$ isolamento político de Tibério com a morte de Druso Cláudio e a ascensão de Sejano também provocaram efeitos na condução dos julgamentos por traição. Sobre a maneira como Sejano se valerá politicamente disto, abordaremos adiante. Mas é necessário que ampliemos o foco sobre as confiscações associadas às condenações. No que tange aos primeiros anos de governo, Dion Cássio afirma ${ }^{504}$ que Tibério não pusera ninguém à morte pelo seu dinheiro, não confiscara os bens de ninguém, e tampouco recorreu a métodos traiçoeiros para obtenção de fundos. Todavia, a partir de seu afastamento para Capri, Dion Cássio apresenta ${ }^{505}$ um novo panorama da relação de Tibério com as confiscações: sob o governo deste todos que acusavam alguém recebiam dinheiro em grandes somas, tanto do erário público quanto dos bens das vítimas. Esta sentença apresenta maior sentido se relacionada, por exemplo, com a condenação do procônsul Sexto Mário reportada por Tácito e apresentada mais adiante ${ }^{506}$, já nos anos finais do governo de Tibério, embora, diferentemente deste último autor, Dion Cássio é

\footnotetext{
${ }^{503}$ Suetônio, Calígula, 14.5 apud LEVICK 1999, p. 144, e 78-80; SEAGER, 2005, p. 137-8.

${ }^{504}$ Dion Cássio, 57.9.5.

505 Idem, 58.5.8.

${ }^{506}$ Cf. página 254
} 
bem mais explícito em imputar o recrudescimento das condenações por traição como iniciativa fomentada predominantemente pelo próprio Imperador ${ }^{507}$.

Já sabemos que a aplicação da lei não foi exclusiva do governo de Tibério. Quanto às confiscações, as menções aparecem antes de seu afastamento, e dois exemplos do período em que Tibério permaneceu em Roma são as mencionadas condenações de Libo Druso (16 d.C.) e Cneio Pison (20 d.C.), embora neste caso Tibério tivesse impedido que metade dos bens de Pison fosse confiscada pelo Senado, em que aparentemente alguns de seus membros teriam sido os grandes interessados.

Por outro lado, durante $o$ ano de 24 d.C. Tácito afirma ${ }^{508}$ que, mediante intenções implícitas de Sejano, os senadores Gaio Sílio e Títio Sabino foram acusados de traição, tendo sido acrescido à Sílio o fato de que, enquanto comandante de um poderoso exército durante sete anos, e após ter ganhado uma insígnia triunfal como vitorioso na guerra contra as hordas de Sacrovir, disseminou-se o temor de que a soberania de Tibério não teria sobrevivido se as legiões sob o comando de Sílio tivessem seguido o mesmo exemplo de amotinação das tropas na Germânia e na Panônia.

Aos impulsos revolucionários que poderiam emergir do comando das tropas por Sílio somou-se o pretenso ressentimento do Princeps por Sósia Gala, esposa de Sílio e amiga de Agripina; por conseguinte, a decisão tomada pelo Senado foi a de indiciar ambos, embora Sabino tenha visto o adiamento de sua acusação. Contudo, Sílio foi condenado sob a lei de traição, embora o pretexto tenha sido o de extorsão, o que culminou com o seu suicídio antes da formalização da pena ${ }^{509}$.

Em seguida, Tácito complementa ${ }^{510}$ que mesmo assim os bens de Sílio foram assolados: o dinheiro confiscado não retornou para os contribuintes nas províncias, embora as quantias previamente conferidas a ele mediante benefício de Augusto foram retiradas de sua propriedade, com uma calculada especificação da parte que seria demandada para o fisco, e a primeira vez que Tibério interessou-se pelo dinheiro alheio. Sósia Gala foi conduzida ao exílio e, de acordo com a proposição do senador Asínio Galo, demandou-se que

\footnotetext{
507 Ibidem, 57.23.1.

508 Tácito, Anais, 4.18.1-3.

509 Idem, 4.19.1-4.

510 lbidem, 4.20.1.
} 
metade de seus bens fosse confiscada e a outra metade deixada para os filhos, condição negada pelo senador Mânio Lépido, que assegurou a concessão de apenas um quarto dos bens para os acusadores, e o restante para os filhos ${ }^{511}$.

Dois outros - e extremamente importantes - casos ocorrerão em 32 e 33 d.C., com a confiscação dos bens de Sejano e a retenção das minas de ouro e prata de Sexto Mário sob intervenção direta do Princeps ${ }^{512}$. É difícil encontrar evidências que atestem quais teriam sido as intenções de Tibério, principalmente com relação às minas, mas é provável que a intenção tenha sido provir o erário público por meio de uma intervenção direta do Imperador, o que não apresenta nenhuma novidade, uma vez que a prática já existia sob Augusto; indícios de austeridade financeira e escassez de moedas são relacionáveis com o custo da administração provincial e a manutenção do exército, e é exatamente em 33 d.C. que observamos uma crise financeira envolvendo a aristocracia proprietária de terras em Roma. Se realmente estes indícios são plausíveis ou não, observaremos adiante ${ }^{513}$. De todo modo, como nas demais esferas de atuação do Senado desde então, a interferência do Princeps eclipsou a autonomia efetiva do Senado e, tanto em relação à administração provincial quanto financeira, os interesses políticos individuais dos senadores passaram a se encontrar em segundo plano perante contingências estruturais do Império ${ }^{514}$.

Em linhas gerais, o gradual aumento das acusações e as condenações por traição foram a grande mancha na relação entre Tibério e os senadores a partir dos primeiros anos de governo em Roma, e o afastamento do Princeps por fim contribuiu para que este problema se amplificasse, com a inserção de Sejano, Macro, e dos interesses políticos em disputa que, especialmente em relação à questão sucessória, se somaram à competitividade e os interesses pessoais dos senadores. Desta maneira, estas considerações refletem sobre este e o tópico anterior, pois os problemas decorrentes da aplicação da lei sob o crime de traição inserem-se decisivamente no âmbito das relações entre Tibério e o Senado. Todavia, de acordo com Richard Bauman ${ }^{515}$, uma das mais

\footnotetext{
511 Ibidem, 4.20.2.

512 lbidem, 6.2.1; 6.19.1.

513 Tácito, Anais, 6.16. Cf. página 228 em diante.

514 LEVICK, 1999, p. 77.

515 1971, p. $113,119$.
} 
notáveis características da atuação de Sejano como auxiliar de Tibério foi a maneira sofisticada, lógica e sistemática com a qual o primeiro valeu-se do aspecto difamatório da maiestas enquanto instrumento político.

Neste sentido, a minúcia desta prática passou a coexistir com um elemento formal dentro das relações entre Princeps e membros da aristocracia que acima foram mencionadas: todas as questões relevantes para 0 funcionamento do Estado e coexistência de seus membros deveriam passar pelas mãos do Senado. Todavia, o que se viu na prática foi a dificuldade de sustentação desta regra; os senadores atuavam na medida de seus interesses, e os limites de interação dos senadores deveriam ser estabelecidos pelo Princeps, o que no caso de Tibério foram demasiado amplos, e justamente esta característica não conseguiu impedir o surgimento de incompreensões sobre a dimensão do poder do Imperador, quais eram as possibilidades de liberdade de expressão política de seus concidadãos, e aquilo que, em termos de iniciativa, ambos deveriam esperar um do outro. Entre Roma e Capri, a ação dos acusadores demonstrará o terreno movediço - ou as orelhas do lobo - que representaram a interação entre estes dois segmentos.

Mas esta é uma ambiguidade concernente ao próprio processo de constante experimentação política que representou o Principado, especialmente durante seu início sob o comando dos Césares JúlioClaudianos. Quando Tácito sintetiza os primeiros e "bons" anos do governo de Tibério, podemos compreender que se trata de um período em que Tibério incentivou - principalmente por meio de sua presença - que o Senado agisse como uma instituição formuladora da política imperial; esta prerrogativa não se modificou, mesmo quando o Princeps deixou Roma. Como detentor do imperium, a condução do exército era importante e delicada demais para ficar nas mãos do Senado; o mesmo podia ser dito da administração das províncias, cujos governadores estavam inevitavelmente vinculados à pessoa do Imperador; e os segredos da casa imperial passaram ao largo de qualquer debate: o assassinato de Agripa Póstumo e seu ex-escravo Clemens, questões que como inúmeras outras concernentes à manutenção do poder imperial, eram resolvidas primeiramente entre o Princeps e seus conselheiros.

O Senado, tendo adquirido uma forte característica de corte de justiça e organismo deliberativo durante o governo de Augusto, e mais ainda durante 0 
governo de Tibério, e pelo menos desde o último século do período republicano, esteve às voltas com a exploração política de segmentos rivais. Com o Principado, seus membros tornaram-se cada vez mais dependentes e comprometidos ao posicionamento manifestado em seus votos, o que fez com que a vinculação a um ou outro grupo impedisse (se considerarmos o que há de plausível em meio à atmosfera de temor e ressentimento que por vezes aparece nas narrativas) que a instituição realmente agisse como um genuíno corpo deliberativo.

Indubitavelmente, o afastamento de Tibério para Capri contribuiu para reforçar esta condição, fato que também contribuiu para a ascensão de Sejano, e em relação a este último aspecto, também para a intensificação das rivalidades e a impressão de paranoia e vingança política que se seguirá à reviravolta provocada por sua eliminação, de seus apoiadores e a retomada das acusações por Macro, Gaio César e seus associados aspirantes a um favorecimento futuro consecutivo à morte de Tibério.

Todavia, os efeitos da malograda política senatorial concebida por Tibério já se apresentavam com ele ainda em Roma. Percebemos que 0 Princeps era assíduo participante das deliberações da assembleia e do fórum, e sua presença e interesse poderia manter a vitalidade dos debates políticos e das deliberações dos senadores. Dion Cássio sintetiza ${ }^{516}$ como o comportamento de Tibério parecia tornar sempre muito difícil qualquer tentativa de compreensão sobre seus reais sentimentos e interesses políticos; mas é inegável que, em relação ao que poderia ser ou não aventado ao Princeps, a presença do mesmo no cotidiano político tornava a possibilidade de ofender ou contrariar sua opinião algo um pouco mais difícil. Neste momento, o Princeps representava fisicamente o cerne de orientação da política imperial e de controle dos interesses aristocráticos em disputa.

Desde o início de seu governo, os senadores se mostraram hesitantes sobre a quantidade de assuntos que poderiam ser discutidos com a ausência de Tibério; o debate entre Cneio Pison e Asínio Galo, em que a liberdade de expressão e a autonomia política do Senado foram vencidas pelo argumento de que as deliberações só possuíam real prestígio quando conduzidas aos

${ }^{516}$ Dion Cássio, 57.1. 
olhos do Princeps, estabeleceu um complicado precedente. Isso pôde ser verificado pela condução imediata da questão dos limites sobre a extravagância da vida doméstica senatorial para Tibério, ausente entre 21 e 22 d.C.. Com o afastamento de Tibério para Capri, o processo de resolução dos assuntos senatoriais sofreu um retardamento em decorrência da ausência do Princeps: além de demorar mais tempo para se realizar, o ato de consultar o Senado passou a perder boa parte do vigor na mesma medida em que se tornou cada vez menos frutífero que seus membros se esforçassem por constituir uma verdadeira opinião.

Não acreditamos que o arrefecimento dos ânimos tenha sido algo preconcebido por Tibério; as evidências mencionadas nos transmitem a impressão de uma genuína iniciativa de promoção do Senado como a instituição que deveria fornecer apoio para que o Princeps mantivesse legitimamente o consenso imperial. Preferirmos acreditar que o desestimulo tenha sido um efeito colateral do afastamento de Tibério, motivado aqui principalmente pelo seu desgaste em relação à interlocução com a maior parte de seus pares políticos.

Assim, o afastamento de Tibério foi um importante momento de inflexão política, pois uma vez que o centro do governo tornou-se o próprio Imperador, sua ausência fez com que a posição desta instituição consequentemente se enfraquecesse. Isto não se originou com Tibério; basta considerarmos os esforços de Augusto para retomar a assiduidade dos senadores aos encontros, e as divergências que provavelmente existiram perante a opinião pública senatorial diante da severidade de suas reformas. Igualmente, o Principado como processo de experimentação baseado em elementos republicanos fez com que Tibério recorresse à alternativa de estimular que os senadores agissem com (certa) independência: os referenciais disponíveis neste momento ou eram aqueles perceptíveis da prática política de Augusto, ou as anteriores matizes republicanas, cuja literalidade de suas concepções não significava a melhor escolha, se sua intenção fosse permanecer de fato no poder.

De um lado, a inconsistência de Tibério revelou-se um obstáculo, justamente pela ausência de referenciais anteriores quanto a regras específicas para delimitar seu comportamento perante o Senado. Este, por sua vez, longe de ser um grupo político homogêneo, era composto por indivíduos 
com interesses específicos e muitas vezes conflitantes uns com os outros. Igualmente heterogênea era a aceitação ou o apreço pela figura do Princeps, e embora o Senado representasse um conjunto de interesses que tradicionalmente justificaram sua existência, o sistema político imperial em construção privilegiava, acima de tudo, as lutas por interesses, e em um segundo plano os debates sobre suas responsabilidades. As tensões entre as instituições republicanas e um sistema baseado na centralização do poder já apresentaram problemas durante o governo de Augusto ${ }^{517}$.

Compreendemos que Tibério já não contava com um livre acesso a estes preceitos: entre o fim da República e seu antecessor já havia se passado cinco décadas, e o Senado era bastante diferente em composição e em expectativas. Estas tensões eram sentidas pelo Imperador e também pelos membros do Senado; as acusações, condenações e suicídios emergiram em decorrência de uma prática alimentada pela própria necessidade dos senadores. Diferentemente de Augusto, a habilidade de Tibério em coordenar de maneira formal e informal o Império (a despeito dos reveses que também existiram no governo de seu antecessor) aparentou relativo êxito durante os seus primeiros anos de governo. Contudo, as mortes de Germânico (cuja postura de distanciamento de parte do Princeps, de Lívia Drusila e de Antônia) e de Druso Cláudio (um golpe para a transição do poder) abalaram o posicionamento do Princeps, uma vez que não isolamos questões referentes à corte imperial e o Senado. Deste modo, a difícil relação com os membros desta instituição se constituiu gradualmente como outra intempérie.

A nosso ver, uma evidência salienta os rumos que Tibério tomaria em relação à continuidade do exercício do poder em Roma. Sobre esta evidência, Dion Cássio nos informa (57.24.1) que - contrariamente a Augusto - passados os dez primeiros anos de seu governo (24 d.C.) Tibério não teria solicitado nenhuma aclamação pública para que o mesmo fosse renovado, não obstante o festival comemorado ao decênio de seu poder tenha sido igualmente celebrado pelo Senado.

Este fato não é mencionado em nenhuma das outras narrativas, e isoladamente nos parece intangível. Entretanto, embora Tibério não tenha

${ }^{517}$ ALSTON, 1998, p. 37, 39; LEVICK, 1999, p. 86-88; WIEDEMANN, 2008, p. 211. 
deixado de ser Princeps e continuar governando, uma associação entre as mortes dos dois candidatos mais próximos para a sucessão imperial, o começo da ascensão de Sejano e, por último, o pouco caso que Tibério teria tido pela celebração da continuidade de seu poder imperial nos leva a crer que, uma vez que não tenha abdicado do poder de governar, Tibério poderia ter deixado implícito mediante esta atitude o princípio de um esvaziamento de sua posição de deferência em relação ao Senado, tendo demonstrado um forte indício de seu desejo de afastamento e de afunilar as suas interações com a aristocracia da Cidade de Roma. Para tanto, a influência de Sejano será um componente fundamental para a compreensão deste processo. 


\section{4 - A ascensão de Sejano e a morte de Druso}

A ascensão política de Lúcio Aélio Sejano foi anterior ao afastamento de Tibério para Capri. Devemos fazer um recuo histórico para que compreendamos melhor a influência que o prefeito da guarda pretoriana deteve neste processo e sua articulação com o Princeps, a família imperial, o Senado, e inclusive em relação a alguns aspectos da administração imperial; após a morte de Druso Cláudio em 23 d.C., a história do Principado de Tibério passou a ser também a história da notável ascensão de um equestre a uma posição de comando e influência comparável apenas à de Marcos Agripa durante o governo de Augusto, embora não tenha sido idêntica. Oito anos mais tarde, a sua eliminação promoveu uma reviravolta política cujas consequências se mostraram decisivas para os últimos anos deste governo.

Nesse sentido, Tácito inicia o quarto livro de seus Anais anunciando o fim de um período de florescimento na residência imperial e a mudança dos rumos da Fortuna; o começo e a causa teriam sido Sejano ${ }^{518}$. Oriundo de linhagem equestre e nascido em Vulsinii, na Etrúria, o pai de Lúcio Aélio Sejano foi Seio Estrabão, apontado por Tibério como prefeito da província do Egito em 15 d.C., e um dos primeiros magistrados a jurar fidelidade ao Princeps após a anunciação de sua ascensão ao poder ${ }^{519}$.

Veléio Patérculo afirma ${ }^{520}$ que Sejano nasceu de um pai que estivera entre os mais proeminentes da ordem equestre, vinculado maternalmente a antigas e ilustres famílias agraciadas com honras públicas, acompanhado de irmãos, primos e um tio (avunculum) que chegara ao consulado. Sobre este tio, Sumner ${ }^{521}$ argumenta que o parentesco se deveu a Quinto Júnio Bleso, cônsul suffectus em 10 d.C., cujo filho de mesmo nome foi também cônsul em 26 d.C.. Em 1977, uma inscrição do período augustano encontrada na mesma região [atual Bolsena, Itália] foi dedicada à gens Seii, em que se atribuiu uma probabilidade de parentesco com a família de Sejano. A partir desta inscrição,

\footnotetext{
${ }^{518}$ Tácito, Anais, 4.1.1.

${ }^{519}$ Idem, 1.7.2.

${ }^{520}$ Veléio Patérculo, 2.127.3.

${ }^{521} 1965$, p. 136.
} 
Corbier $^{522}$ complementou o estudo inicial feito por Sumner ao afirmar que as menções feitas acima por Tácito e Veléio Patérculo permitem situar o nascimento de Sejano em algum momento entre 20 e 10 a.C., e que os dois administradores do abastecimento de água (curatores aquae) citados na inscrição podem ter sido parentes de Lúcio Seio Estrabão, Lúcio Seio Tubero (possivelmente adotado) e Sejano, respectivamente pai e filhos; quando Tibério assumiu o governo de Roma, Seio Estrabão era prefeito da guarda pretoriana, e logo Sejano foi nomeado seu colega de cargo.

Durante sua juventude, Sejano havia acompanhado Gaio César para o Oriente, recebido favorecimentos de certo Apício, e posteriormente conquistado a confiança de Tibério ${ }^{523}$. Esta informação relaciona-se à primeira inferência a ele feita como o mentor de Druso Cláudio em seu deslocamento para a Panônia, imediatamente após o início do motim entre as legiões na região. Não sabemos de fato qual fora a relevância desta proximidade inicial à Druso, mas naturalmente Sejano já detinha, pelo controle conjunto da guarda pretoriana, um forte destacamento militar que pode ter sido considerado de grande valia no conflito.

É importante ressaltarmos que o exército romano foi uma fonte crucial do poder imperial e o seu apoio - ou a ausência do mesmo - contribuiu para elevar e derrubar Imperadores, tendo em vista que seus membros eram os representantes mais numerosos do estado romano e desempenharam muitas das tarefas básicas requeridas para o funcionamento do império. Mais ainda, as demandas desta política continuaram por gerar conquistas e ampararam uma ideologia de expansão imperial, e assim como a competição política durante a República conduziu indivíduos poderosos a buscar glória militar expandindo o império, o sucesso militar foi uma importante característica de um Imperador bem sucedido ${ }^{524}$.

Mais especificamente em relação às origens da guarda pretoriana, Sandra Bingham afirma ${ }^{525}$ que a data mais provável para a oficialização da existência de uma guarda pessoal do Princeps é a de 27 a.C., em conjunção com a aceitação dos poderes de Augusto. $O$ estabelecimento de uma guarda

\footnotetext{
522 1983, p. 746-56.

${ }^{523}$ Tácito, Anais, 4.1.2.

${ }^{524}$ POLLARD, 2006, p. 206-217.

${ }^{525}$ 1997, p. 23-35.
} 
regular e centralizada derivada das corporações de tropas selecionadas que protegiam os oficiais republicanos foi uma importante inovação deste Princeps, que em meio às tradicionais proibições republicanas da presença regular de tropas no interior do pomerium, cavara uma brecha fulcral ao assegurar a presença de três coortes pretorianas no interior da Cidade (junto com três coortes urbanas, essencialmente um destacamento para militar de policiamento), ao passo que o restante permanecia estacionado em cidades no entorno de Roma.

Nesse contexto, Dion Cássio afirma ${ }^{526}$ que havia, além das coortes urbanas e da guarda pretoriana, cerca de vinte e três ou vinte e cinco legiões, acompanhadas de forças aliadas de cavalaria, infantaria e de marinheiros, sobre as quais ele admite não ter precisão quanto ao contingente, embora mencione que a guarda pessoal do Imperador era composta por dez mil soldados organizados em dez subdivisões. O fato de estes soldados receberem o dobro dos demais aparece como um aspecto de distinção, e uma consequência da necessidade de se manter a fidelidade destes ao seu general durante o final da República. Igualmente, a segurança da família imperial foi outro motivo coerente para que o Princeps garantisse um bom soldo para os seus soldados; durante o período dos Césares Júlio-Claudianos a guarda pretoriana ampliou sua funcionalidade inicial predominantemente militar para outra, abarcando demandas de ordem administrativa e do interesse do Imperador.

Os pretorianos agiram como uma força militar estratégica geralmente convocada para situações em que outras medidas de intervenção mostravamse ineficazes, ou onde havia uma necessidade de ação sigilosa (as ações tidas como "clandestinas" eram postas a cargo da divisão dos speculatores), e envolvida também com ações de prisão, confinamento e execução daqueles que eram considerados e julgados como ameaças à res publica. Embora haja uma imprecisão sobre a extensão da atuação política dos membros da guarda pretoriana, estes eram destacados para encorajar um recalcitrante ao suicídio e prender um acusado, bem como podem ter sido envolvidos na tortura de supostos conspiradores, ou mesmo feito o papel de acusadores, não obstante

${ }^{526}$ Dion Cássio, 55.24.5-6. 
haja pouca evidência que possa atestar um regular emprego destes soldados para tal prática.

Os pretorianos também fizeram parte da rotina da administração civil da Cidade de Roma, auxiliando os vigiles no combate a incêndios e como seguranças durante jogos e peças de teatro; a guarda possuía aptidão para o desempenho nestas tarefas precisamente por ser a unidade militar exclusiva do Imperador e adaptada a quaisquer tipos de necessidades que surgissem com sua convocação. O pragmatismo parece ter marcado seu relacionamento com o Princeps, tendo desempenhado conscienciosamente as deliberações a estes imputadas, bem como se mostrando pouco afeitos à ideia de pôr em risco sua posição privilegiada ${ }^{527}$.

Em relação à participação da guarda durante o governo de Tibério, Tácito afirma ${ }^{528}$ que o poder da prefeitura do pretório, que até então tinha sido moderado, foi ampliado pelo Princeps com a união das tropas em um único acampamento: estas podiam receber ordens simultaneamente, e o numerário resultante da concentração aumentara a autoconfiança dos soldados e o temor dos demais; as tropas espalhadas tornavam-se insubordinadas e um auxílio compacto seria mais efetivo em caso de uma emergência e menor seria a lassidão da conduta se um destacamento fosse criado a uma razoável distância das atrações da Cidade.

Consequentemente, Sejano ampliou a força de influência política da guarda pretoriana e a aliança com seus membros; os tribunos e centuriões, que deveriam ser escolhidos pelo Princeps para integrar a guarda, na verdade eram escolhidos por Sejano, conquanto fosse próprio ao Imperador aceitar as sugestões deste último: após a criação do novo acampamento, Tácito afirma ${ }^{529}$ que Sejano começou a se insinuar à afeição dos soldados, aproximando-se de cada um e chamando-lhes pelo nome, ao mesmo tempo em que selecionava pessoalmente os centuriões e tribunos das tropas. A composição deste contingente em sua maior parte era escolhida de indivíduos oriundos da Úmbria, Etrúria, da antiga região do Lácio ou das antigas colônias romanas ${ }^{530}$.

\footnotetext{
${ }^{527}$ BINGHAM, 1997, p. 7-9.

${ }^{528}$ Tácito, Anais, 4.2.1; De modo semelhante, Dion Cássio, 57.19.6; Suetônio, Vida de Tibério, 37.1.

${ }^{529}$ Tácito, Anais, 4.2.2.

${ }^{530}$ Idem, 4.5.3.
} 
Com esta modificação, Tibério (e em certa medida Sejano) criou um precedente decisivo para o aumento da influência política da guarda pretoriana, tanto no apoio quanto na derrubada de um Imperador - como os respectivos casos de Cláudio e Nero -, embora a mesma influência tenha se provado menos bem sucedida em mantê-los em face de oposição de outros elementos do exército, como virá a ocorrer posteriormente a outros Imperadores. Entretanto, é necessária a diferenciação entre a ação e a pressão coletiva dos membros da guarda e outra protagonizada pelos seus representantes: os pretorianos podiam exercer uma influência na política interna para o benefício ou detrimento do Imperador em exercício, mas foi principalmente o interesse de alguns de seus principais representantes por ascensão política que contribuiu para a confirmação histórica dos efeitos da guarda sobre o Imperador e os segmentos mais próximos da esfera de influência e promoção política, exemplificados nos caso de Sejano, Macro, e posteriormente de Rúfio Crispino (43-50 d.C.), promovido pelo Senado como pretor durante o governo de Cláudio por ter aplacado uma rebelião, e de seu sucessor Sexto Afrânio Burro (51-62 d.C.), preceptor - junto a Sêneca - do jovem Nero.

Por exemplo, Dion Cássio afirma ${ }^{531}$ que, por volta do ano de 25 d.C., Tibério teria oferecido aos senadores uma exibição do treinamento da guarda pretoriana, como se os primeiros desconhecessem o poder destas tropas, e de modo a deixá-los mais temerosos do Imperador, uma vez que eles puderam observar como os seus defensores eram fortes e numerosos. Mediante esta percepção, os pretorianos, além da evidente proteção militar ao Imperador, poderiam intimidar o Senado e o restante da população, uma menção de uma ameaça implícita. Durante o governo de Tibério, a guarda pretoriana começou a se desenvolver enquanto uma unidade militar caracterizada por uma coesão em sua formação e pelos efeitos que esta coesão impôs-se sobre o cenário político da Cidade de Roma.

Esta interação provavelmente contribuiu para reforçar o sentimento de que estes soldados faziam parte de uma unidade de elite responsável pela segurança do Princeps e da família imperial - não sem influência política - e da segurança da res publica. Esta importância é latente mesmo após o

${ }^{531}$ Dion Cássio, 57.24.5. 
assassinato de uma figura tão proeminente em termos políticos como foi Sejano; Tibério mantivera-se atento à manutenção da lealdade das coortes, mesmo que estas não tivessem tido, de acordo com as nossas evidências, uma oportunidade para demonstrar publicamente sua aliança, como ocorreria posteriormente com Cláudio. Todavia, o aumento da importância e a influência crescente dos pretorianos com o reconhecimento de seu estatuto privilegiado durante o Principado de Tibério apresentou paradigmaticamente a influência que futuramente este grupo militar desempenharia nos governos posteriores ${ }^{532}$.

Explicitadas as principais características que envolveram o cargo exercido por Sejano, observamos também que sua ascensão inseriu-se no contexto de ampliação da promoção política dos homens novos e da ordem equestre durante o início do Principado. Provavelmente já neste período Sejano estivesse buscando expandir sua influência no Senado ao intermediar magistraturas para seus apoiadores: um exemplo é a menção ao pretor Júnio Oton em 22 d.C., tido como um dos acusadores de Gaio Silano ${ }^{533}$. A aristocracia senatorial e equestre contou com o apoio de Tibério: membros de ambas foram destacados para as dez centúrias criadas em homenagem a Gaio e Lúcio César por meio da Lex Valeria Cornelia de 5 d.C. (já neste ano Augusto havia estabelecido assentos especiais para os equestres próximos aos dos senadores no anfiteatro), bem como para as outras dez centúrias criadas em homenagem aos falecidos Germânico César e Druso Cláudio.

Tibério (como muitos de seus associados) também possuía antecedentes equestres, entre eles sua avó Alfídia e sua primeira sogra Cecília, e como a maior parte dos outros senadores, amigos equestres como Sejano, sendo que esta vinculação deve ter sido de grande estima para seus membros ${ }^{534}$. Mais ainda, durante o governo de Tibério o prestígio desta foi reafirmado de modo semelhante a Augusto: um senatus consultum de 23 d.C. estabeleceu que o uso do anel de ouro (um dos símbolos de distinção da ordem) só seria permitido àqueles que tivessem avôs paternos livres e correspondessem aos requisitos censitários; em 24 d.C a Lex Visellia instituiu

\footnotetext{
${ }^{532}$ ALSTON, 1998, p. 211-3; BINGHAM, 1997, p. 43-5.

${ }^{533}$ Tácito, Anais, 3.66.3, 4.2.3.

534 LEVICK, 1999, p. 89; SEAGER, 2005, p. 152-3.
} 
que libertos que se passassem por livres seriam passíveis de condenação ${ }^{535}$. Em contrapartida, Tibério era consciente das diferenças de posição social entre senadores e equestres proeminentes, fato perceptível pela correspondência apresentada por Tácito sobre o pedido de casamento de Sejano a Lívia Júlia ${ }^{536}$.

Todavia, a carreira de Sejano apresentou duas particularidades que se converteram em questionamentos. De acordo com Robin Seager ${ }^{537}$, o primeiro está relacionado às iniciativas no interior do palácio imperial: Tibério teria usado Sejano e seus interesses como ferramenta contra o núcleo político de Agripina e seus filhos, ou teria Sejano manipulado Tibério como maneira de assegurar sua ascensão? Suetônio afirma ${ }^{538}$ que Tibério promovera Sejano à mais alta posição de poder menos por consideração do que pelo fato de que este último poderia servir para destruir os filhos de Germânico e para assegurar a sucessão para seu próprio neto, Tibério Gemelo, filho de Druso Cláudio.

Para Tácito ${ }^{539}$, Sejano permitiu que Tibério extravasasse sua ferocidade e consentisse com a crueldade de outros, tendo o deixado livre para agir, sem poupar nem mesmo amigos ou parentes, como sua mãe, seus netos, sogra, e finalmente o próprio prefeito da guarda ${ }^{540}$. Diante deste contexto, o que observamos em verdade foi uma excessiva predisposição de Tibério em atribuir credibilidade às palavras de Sejano que, por sua vez, foi habilidoso ao explorar a desconfiança de Tibério sem a que este último demandasse provas ou demonstrações de plausibilidade diante de acusações e intrigas sobre sua pessoa, um excesso de confiança que encorajou a ambição do prefeito da guarda pretoriana ${ }^{541}$.

O segundo questionamento consiste na dificuldade em saber qual foi 0 objetivo de Sejano. Remetendo-nos novamente ao ano de 23 d.C., após este ter conseguido reorganizar a guarda pretoriana, Tácito afirma ${ }^{542}$ que a residência dos Césares ainda estava cheia: um jovem filho e dois netos era um atraso aos seus desejos, e como a simultânea apreensão de tantos por meio

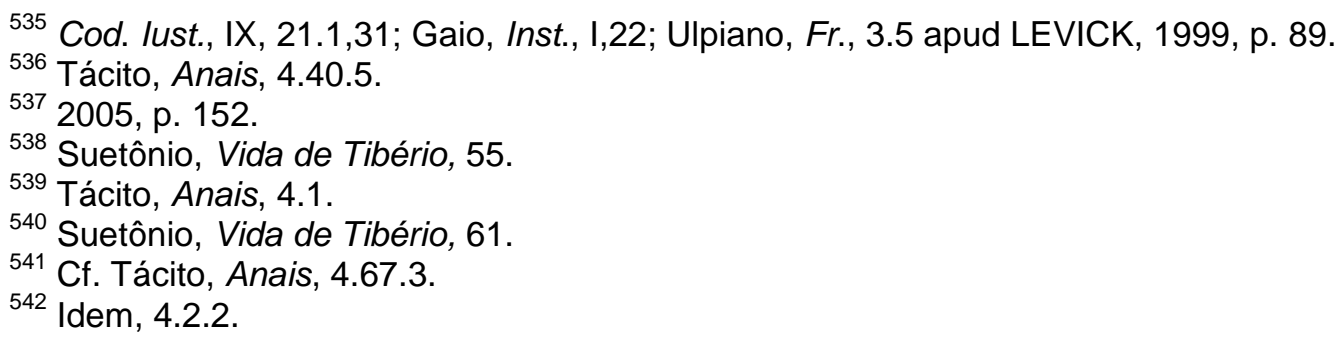


da violência era inseguro, havia necessidade de intervalos entre os crimes; o início se deu então com Druso Cláudio. A inferência sobre os jovens príncipes também é importante: este último agiria como um guardião de Nero, e a despeito de ser este e o jovem Druso politicamente inexperientes, ambos já haviam alcançado a maioridade, e seria uma questão de tempo para que estivessem aptos a se tornarem Imperadores.

Desta maneira, mais plausível do que o desejo de se tornar Princeps, provavelmente Sejano pretendera se tornar guardião de um príncipe ainda muito novo para governar. Diante desta possibilidade, a existência de Druso Cláudio como guardião de Nero e Druso, bem como a influência de Agripina teriam sido os principais empecilhos para que Sejano se tornasse guardião de Tibério Gemelo e se aproximasse efetivamente do círculo de poder imperial ${ }^{543}$. Mais ainda, provavelmente a posição de Princeps seria algo não tolerado pela aristocracia senatorial, uma vez que Sejano era um membro da ordem eqüestre, e o restante das legiões e da plebe se mostrava mais favorável à sucessão de um membro da família imperial.

Em uma síntese de sua ascensão, Dion Cássio afirma ${ }^{544}$ que Tibério elevou Sejano ao estatuto de pretor, uma honra que ainda não havia sido concedida a outro indivíduo de sua ordem social, um vínculo colaborativo como assistente e conselheiro de Tibério em todos os assuntos, bem como a construção de uma estátua de bronze no teatro durante a vida de seu colega de governo, fato acompanhado da celebração de efígies por diferentes indivíduos, e a realização de elogios perante senadores e o povo ${ }^{545}$.

Além dos espaços públicos, os cidadãos mais proeminentes e mesmo os cônsules passaram a frequentar regularmente a residência de Sejano ao amanhecer, comunicando a este não somente todas as solicitações privadas que os primeiros desejavam pronunciar a Tibério, mas também os assuntos públicos que deveriam ser discutidos, o que leva Dion Cássio a concluir ${ }^{546}$ que, principalmente após a morte de Druso Cláudio, nada escapou de seu conhecimento. A referência comparativa às salutationes imperiais nos leva a

\footnotetext{
543 SEAGER, 2005, p. 153.

${ }^{544}$ Dion Cássio, 57.19.7.

${ }^{545}$ Idem, 57.21.3.

${ }^{546}$ Ibidem, 57.21.4.
} 
concluir que Sejano adquirira uma influência significativa cujo impacto foi sentido pela aristocracia senatorial a partir de então.

Uma evidência para tanto se encontra no fato de Veléio Patérculo dedicar dois capítulos de seu epítome para expor as razões pelas quais Tibério teria agido corretamente na escolha de Sejano enquanto colaborador político. Inicialmente, ele busca relações com ilustres equestres para justificar a escolha de Tibério:

Raros foram os eminentes homens que falharam ao terem se valido de homens não menos dignos para auxiliá-los na condução de seus destinos, assim como os dois Cipiões empregaram os dois Laélios, que em relação a todos os assuntos consideraram-se como iguais, e como o Divino Augusto empregou M. Agripa ou depois deste Estatílio Tauro, os quais a condição de homens novos não lhes privou de sucessivos consulados, triunfos e inúmeros pontificados. Mais ainda, grandes empreitadas requerem grandes colaboradores, e é importante que àqueles cujo emprego seja necessário ao Estado sua posição social seja elevada e sua utilidade fortificada pela autoridade. Sob estes exemplos Tibério César teve e ainda têm enquanto associado Élio Sejano, nascido de um proeminente membro da ordem equestre, mas em verdade pelo vínculo materno advindo de antigas e ilustríssimas famílias agraciadas por honras públicas, possuindo irmãos, primos e um tio que ascendeu ao consulado, e ele mesmo grande capacidade para o trabalho e indubitável lealdade, bem como pleno vigor de espírito e tenacidade de corpo, o único que assistiu bem como ainda assiste ao Imperador no auxílio de seus deveres mais árduos; um homem de austeridade serena e cordialidade dos mais antigos. Alguém que mesmo nada reivindicando tudo obtém, colocando-se sempre abaixo de outros em estima, de expressão e vida serena, mas de mente incansavelmente alerta ${ }^{547}$.

${ }^{547} 2.127 .1-4$ 
Veléio complementa ao final do capítulo seguinte ${ }^{548}$ que teriam sido estes precedentes naturais que compeliram Sejano a auxiliar o Princeps com as suas responsabilidades, e de modo semelhante o Senado e o povo romano, ao ponto de convocarem para a preservação da sua segurança o homem a quem eles consideravam como o instrumento mais útil. Em consideração a este trecho, Ronald Syme afirma ${ }^{549}$ que a justificativa oferecida por este autor para a escolha do prefeito do pretório como consorte de Tibério não pode ser caracterizada exclusivamente como um elogio, conquanto seja favorável ao primeiro: embora não seja possível precisar quão anterior à ascensão de Sejano ao consulado tenha sido a conclusão de sua obra, Veléio Patérculo enquanto um senador e favorável ao Princeps - não estava alheio a esta possibilidade, embora não seja possível afirmar que este elogio a Sejano possa ser encarado como um indício de uma eventual preferência de Tibério pelo primeiro enquanto sucessor no Principado ${ }^{550}$. Todavia, a justificativa não nos deixa ignorar a possibilidade de que havia uma considerável oposição à ascensão de Sejano, mesmo que não necessariamente articulada. Diante destes prováveis objetivos, o casamento com uma princesa imperial poderia alçá-lo a uma posição de prestígio sem precedentes. Todavia, Druso Cláudio era o primeiro e mais evidente obstáculo. Desde o início, as relações entre ambos não parecem ter sido amigáveis: durante uma discussão Druso, em decorrência de seu temperamento, teria desferido um soco em Sejano (Dion Cássio relata a mesma história, conquanto o agredido tenha sido o príncipe ${ }^{551}$.

Paralelamente, Sejano conseguiu que sua filha fosse prometida a um dos filhos de Cláudio ${ }^{552}$. É concebível que Cláudio tenha ficado bastante descontente por sua exclusão da linha sucessória e pela ausência de participação na vida pública ao longo do governo de Tibério, mas os eventuais netos de Sejano poderiam ser descendentes diretos de Druso Nero e Marco Antônio, e por consequência de Augusto. Igualmente, Cláudio pode ter exercido alguma influência como membro da família imperial: quando seu nome foi excluído da lista de agradecimentos daqueles que teriam vingado a

\footnotetext{
${ }^{548}$ Veléio Patérculo 2.128.4.

549 1978, p. 62-3.

550 LEVICK, 1999, p. 125.

551 Dion Cássio, 57.22.1; Tácito, Anais, 4.3.2.

552 Tácito, Anais, 3.29.5.
} 
morte de Germânico César, o senador L. Asprena questionara o cônsul se tal omissão havia sido deliberada ${ }^{553}$; tendo tido amigos entre os senadores e equestres, é possível que uma de suas mais fortes conexões em um dado momento foi Sejano, que de sua parte percebera que os fortes vínculos sucessórios de Cláudio poderiam ser utilizados como argumento político em uma eventual disputa, pois o período entre a morte de um príncipe e a ascensão de outro tende a ser um terreno fértil para intrigas dinásticas ${ }^{554}$.

Ao assumir o consulado como colega de Tibério em 23 d.C. e receber o poder tribunício, Druso Cláudio não somente despontava como um natural caminho para a sucessão, mas como uma possibilidade para que o Princeps se retirasse do comando; a posição de favorecimento e influência (e talvez a própria vida) de Sejano algo seriamente ameaçado pela indisposição de Druso. Nesta trama dinástica, o envolvimento de Sejano com Lívia Júlia suscita questionamentos: qual teria sido a vantagem de se vincular a Sejano, uma vez que ela naturalmente se tornaria imperatriz com a ascensão de Druso? Provavelmente assegurar uma futura sucessão para seus filhos Tibério Gemelo ou Germânico. É crível que Druso Cláudio manteria o plano sucessório herdado de Augusto para Tibério, e com isso Agripina ascenderia futuramente a uma posição semelhante à de Lívia Drusilla como mãe do Imperador, e o fim da linha para qualquer pretensão de Lívia Júlia ${ }^{555}$.

Contudo, é difícil transpor a especulação: a única definição oferecida sobre Lívia Júlia diz respeito à beleza que adquirira quando se tornou adulta, e que fora seduzida por Sejano ${ }^{556}$ (Dion Cássio afirma ${ }^{557}$ que Sejano estava apaixonado por ela, mas que não pretendia casar-se enquanto não eliminasse Agripina e seus filhos); sua insistência pelo casamento teria inclusive compelido Sejano a escrever uma correspondência a Tibério solicitando permissão dois anos após a morte de Druso Cláudio, em 25 d.C. ${ }^{558}$. Ainda no ano de 23 d.C. Druso, filho mais novo de Germânico César, recebeu a toga viril - com as mesmas cerimônias de seu irmão Nero, ocorrida três anos antes; por volta deste momento Sejano resolveu divorciar-se de Apicata, sua esposa, com

\footnotetext{
${ }^{553}$ Tácito, Anais, 3.18.4.

554 Cf. LEVICK, 1999, p. 126.

555 SEAGER, 2005, p.154-5.

${ }^{556}$ Tácito, Anais, 4.3.3.

${ }^{557}$ Dion Cássio, 57.22.4b.

${ }^{558}$ Tácito, Anais, 4.39.1.
} 
a qual tinha três filhos ${ }^{559}$. Eudemo, médico de Lívia Júlia, teria sido encarregado de ministrar um veneno que gradualmente mataria seu esposo, com a conivência do eunuco Lygdo, provador das refeições de Druso; este teria convalescido durante vários dias, embora Tibério tivesse continuado a participar normalmente das sessões senatoriais, vindo a morrer em 14 de Setembro ${ }^{560}$.

Os autores apontam que esta trama fora revelada oito anos mais tarde, conforme revelado por carta de Apicata deixada antes de seu suicídio, imediatamente após a eliminação de Sejano ${ }^{561}$, mas é difícil comprovar se Druso Cláudio foi envenenado ou morrera em decorrência de alguma doença. É igualmente difícil saber se realmente Apicata sabia de alguma conspiração para o envenenamento do príncipe, se Eudemo e Lygdo tiveram parte na estória, bem como o fato de Apicata ter demorado oito anos para relevá-la; semelhante revelação pode ter sido um artifício a mais dentro do sistemático quadro de eliminação de associados e apoiadores de Sejano após 31 d.C..

Ocasional ou não, a morte de Druso Cláudio abriu um caminho para a ascensão política de Sejano ${ }^{562}$ : mesmo diante do falecimento de seu filho, Tibério buscou manter certa naturalidade no cotidiano político, relembrou os cônsules do honorável aspecto de suas posições, e em meio a uma assembleia argumentou que preferia buscar conforto nos afazeres públicos ${ }^{563}$. Todavia, a consternação de Tibério não teria passado incólume, principalmente no que dizia respeito à sucessão, conforme observamos em Tácito:

Tendo expressado compaixão pela extrema velhice de Augusta, a ainda pouca idade de seus netos e sua própria declinante idade, ele fez com que os filhos de Germânico, a único alívio dos seus presentes infortúnios, fossem conduzidos para dentro [do Senado]. Feito isto e fortalecendo os jovens com palavras de incentivo, os cônsules os escoltaram até 0 César e os posicionaram perante ele. Segurando-os, ele disse:

\footnotetext{
559 Tácito, Anais, 4.3.3-5.

560 Dion Cássio, 57.22.4a; Tácito, Anais, 4.8.1.

561 Tácito, Anais, 4.11.1; ST 62.1; Dion Cássio, 58.11.6.

562 LEVICK, 1999, p. 127; SEAGER, 2005, p. 157; SCULLARD, 2011, p. 233; ALSTON, 1998, p. 31.

563 Tácito, Anais, 4.8.2-4.
} 
"padres conscritos, quando estes dois foram privados de seu pai, eu os passei para seu tio e pedi, embora ele tivesse seus próprios descendentes, que os promovesse, edificasse, os fortalecessem como se fossem de seu próprio sangue, tanto para o seu bem quanto para a posteridade. Agora que Druso foi arrebatado, eu transfiro minhas súplicas a vocês e perante os deuses e a República eu imploro: aceitem, conduzam os bisnetos de Augusto, gerados com a mais brilhante ascendência; preencham sua própria função e a minha. Estes homens estarão para vocês, Nero e Druso, no lugar de seus pais: seu nascimento é tal que seu bem e seu mal afetam o estado" 564 .

Por fim, Tibério solicitou a transmissão de suas responsabilidades e que os cônsules ou alguém tomassem a dianteira do estado, uma afirmação tida como evasiva por Tácito ${ }^{565}$. Verdadeiro ou não, tal desejo era impraticável (Tibério já havia percebido isso em 14 d.C.) e a morte de Druso trouxe a necessidade de Tibério prolongar sua permanência no poder, até que Nero pudesse eventualmente assumi-lo. $O$ isolamento político de Tibério dentro da família imperial foi decisivo para que ele se retirasse para Capri. Se o impacto da morte de seu filho contribuiu para tanto, outras mortes entre 20 e 23 d.C. também se somariam a este prospecto: Cneio Pison (20 d.C.), P. Sulpício Quirino (21 d.C.), e Lucílio Longo (23 d.C., o único que foi para Rodes); sua primeira esposa Vipsânia (20 d.C.), e um dos filhos de Druso Cláudio (Germânico) $^{566}$.

Após a celebração do funeral do falecido príncipe, Tácito afirma ${ }^{567}$ que, a despeito de Druso não ser impopular, o Senado e o povo teriam apreciado secretamente o fato como uma retomada da casa de Germânico, e que Agripina não teria feito nada para disfarçar sua esperança, com a certeza de sua ascensão junto a seus filhos. A expectativa política era evidente, e independente do distanciamento de Tibério e Lívia de sua nora, a sucessão

\footnotetext{
564 3.8.3-5.

565 Tácito, Anais, 4.9.1.

${ }^{566}$ Idem, 3.19.4; 48; 4.15.1.

567 Ibidem, 4.9.12. Sobre o funeral, também Dion Cássio, 57.22.4a; EJ 94b.
} 
parecia algo inequívoco. Sejano teria então se prontificado a aflorar ainda mais os ânimos entre Lívia, Lívia Júlia e Agripina.

Isto não aconteceu sem um bom pretexto: ainda no mesmo ano, e provavelmente logo após Tibério ter conduzido Nero e Druso ao Senado, em ocasião de uma permissão para que cidades da Ásia construíssem um templo dedicado ao Imperador, Lívia e o Senado, em nome do Princeps e do Senado o jovem Nero proferiu um discurso de agradecimento que causou grande impacto na audiência e promoveu recordações da figura de Germânico; a nítida indisposição de Sejano contra o jovem príncipe estava inclusive contribuindo para o aumento da popularidade deste último, conquanto embora intensificasse a desconfiança do Princeps ${ }^{568}$.

Esta situação fez com que Sejano procurasse Tibério e criticasse 0 comportamento arrogante de Agripina em razão de sua numerosa prole, sua popularidade e sua ambição. Além de sua influência, Sejano teria subornado pessoas próximas à corte: Júlio Póstumo, amante de Mutília Prisca, amiga íntima de Lívia, bem como amigos de Agripina instruídos a provocar ainda maiores ambições em Agripina ${ }^{569}$.

Mas foi em 24 d.C. que de fato as intrigas alimentadas por Sejano tornaram-se mais evidentes. Logo no início deste ano, talvez encorajados pelas palavras de apoio que Tibério havia oferecido aos jovens príncipes, os pontífices e outros sacerdotes incluíram os já tradicionais votos de proteção também a Nero e Druso. Todavia, Tibério se irritou com a pretensa equiparação e, após convocar os pontífices, questionara-os se a atitude havia sido uma concessão aos anseios ou ameaças de Agripina. Após a negativa dos primeiros, Tibério apenas impôs uma sutil reprimenda, mas posteriormente alertou o Senado para que ninguém encorajasse em ambos a arrogância pela concessão de honras prematuras ${ }^{570}$.

É possível que tenha havido influência de Agripina, e este fato pode ter sido um indício de sua impaciência, pois ao contrário do precedente estabelecido de antecipar as etapas da carreira pública aos jovens e futuros Césares, Tibério não teria feito o mesmo com Nero e Druso; Nero só se

\footnotetext{
${ }^{568}$ Tácito, Anais, 4.15.3.

569 Idem, 4.12.3-4.

570 Suetônio, Vida de Tibério, 54.1; Tácito, Anais, 4.17.1-3.
} 
tornaria então pretor em 25 e cônsul em 34 d.C.. Por outro lado, é possível que para Tibério a atitude de sua nora tivesse soado como uma repetição da ambição de Júlia Augusta perante Gaio e Lúcio César - plausível motivação para o seu primeiro afastamento de Roma -, e mais um motivo para recrudescer a desconfiança do Princeps, não sem a interferência de Sejano. A razão para este alerta teria decorrido das constantes censuras feitas por este último ao Princeps de uma cisão política: havia os que se intitulavam da facção de Agripina, e sem a construção de uma resistência e da eliminação de um ou outro articulador, poderia haver mais apoiadores ${ }^{571}$.

É importante ressaltar que o que se configurou como uma "facção" de Agripina não foi um grupo político centrado em interesses específicos e sistematizado. Diante desta definição, também não se tratou da continuidade de uma "facção" de Germânico César: sua morte teria promovido uma dispersão de seus apoiadores, aparentemente retomada em 24 d.C. com 0 ressurgimento de hostilidades habilidosamente exploradas por Sejano, não obstante com uma vinculação mais direta à Agripina e aos príncipes deste núcleo familiar no processo sucessório, principalmente por sua influência pessoal dentro da corte imperia| ${ }^{572}$.

Consequentemente observamos que, com o recurso à exploração das acusações e condenações pelo crime de traição, iniciou-se uma eliminação sistemática dos apoiadores do núcleo familiar de Agripina e ao isolamento de associados e amigos. Deste modo, no mesmo ano de 24 d.C. Tácito afirma ${ }^{573}$ que a proximidade e influência dos senadores $C$. Sílio e do equestre Títio Sabino perante Agripina fizera com que Sejano os atacassem: ambos eram amigos de Germânico, sendo que o primeiro, além de legado do falecido príncipe, havia permanecido fiel aos interesses de Agripina, e sua esposa Sósia Gala uma amiga íntima desta última.

De sua parte, Sabino tinha sido comandante na margem superior do Reno, e a condução de uma vitória contra os gauleses do general Sacrovir teria o tornado arrogante a ponto de ter afirmado que Tibério não se manteria no

\footnotetext{
571 Tácito, Anais, 4.17.3-4; Cf. BAUMAN, 1994, p. 148; LEVICK, 1999, p. 128; SEAGER, 2005, p. 159.

572 BAUMAN, 1994, p. 155-6. Primeira visão sobre o assunto, MARSH, 1926, pp.236-250, questionada veementemente por LEVICK, 1975, pp. 29-38. A nosso ver, o posicionamento de Bauman é uma visão amadurecida sobre esta questão.

${ }^{573}$ Tácito, Anais, 4.18.1.
} 
poder sem a lealdade dos legionários sob o seu comando. Embora 0 julgamento de Sabino tenha sido adiado, Sílio recebeu a acusação de cumplicidade com Sacrovir (sua esposa utilizada como intermediária), o que caracterizava traição. Para a infelicidade de Sílio, Visélio Varro - cônsul neste ano - havia sido rival do primeiro pelo comando das legiões contra Sacrovir; não por acaso Sílio implorou a Tibério que o julgamento fosse prorrogado até 0 final do exercício do cargo de Varro, o que foi negado pelo Princeps: C. Sílio cometeu suicídio, o que não evitou que seus bens fossem confiscados (ao crime de traição foi acrescido o de extorsão, algo admitido, porém não detalhado por Tácito), e Sósia Gala foi exilada, embora com apenas confiscação parcial ${ }^{574}$.

Em meio a esta aparente inflexibilidade e severidade de Tibério impõese uma questão: Agripina teria de fato se envolvido na questão e se mostrado apta a buscar uma aliança por meio de uma rede de clientes e dependentes no interior da Gália? Richard Bauman ${ }^{575}$ afirma que tanto ela quanto Germânico César podem ter se valido do vínculo consanguíneo legado pela ancestralidade a Júlio César para a manutenção destas redes de solidariedade na região; certamente teria existido uma relação de favorecimento entre Germânico César, Agripina e Títio Sabino, ao passo que a relação de amizade com Sílio e Sósia Gala pode ter dado margem à fundamentação destas suspeitas.

Neste sentido, a popularidade que Germânico César e sua família haviam adquirido ao longo dos anos - perceptível na relação mantida com as legiões estacionadas às margens do Reno - pode ter contribuído inclusive para a maneira sutil com a qual Tibério lidou com as perturbações promovidas por Sacrovir na região: o medo de que a revolta na região portasse o interesse de uma transformação no comando do Império (com o apoio de comunidades germânicas e da Hispânia) teria feito com que o assunto fosse mencionado apenas após seu final ${ }^{576}$.

De todo modo, o desfecho do caso demonstrou que, essencialmente, o fato representou uma eliminação política visando o enfraquecimento da rede de apoio ao núcleo familiar de Agripina. Nesse sentido, igualmente importante foi o

\footnotetext{
574 Tácito, Anais, 4.20-1.

575 1994, p. 146-7.

${ }^{576}$ Sobre a revolta de Sacrovir, Tácito, Anais, 3.41-3; a maneira lacônica pela qual Tibério tratou da questão perante o Senado, Tácito, Anais, 3.47.1-2.
} 
julgamento de Víbio Sereno, que havia sido trazido de volta do exílio ${ }^{577}$ para responder a acusações de seu próprio filho homônimo. Tácito afirma ${ }^{578}$ que este último alegou que seu pai conspirara contra a vida do Imperador e enviara agentes para incitar a recente revolta na Gália, uma iniciativa patrocinada por Cecílio Cornuto, ex-pretor, que por sua vez cometera suicídio, embora fosse inocente.

Embora sem provas, o suicídio de Cornuto trouxe ainda mais suspeitas sobre o caso e, de sua parte, Víbio Sereno desafiou o filho a apresentar outros nomes, pois dificilmente ele teria arquitetado tal plano sem ao menos um cúmplice. Como resultado, os nomes apontados foram os de Gneio Cornélio Lentulo e L. Seio Tubero, indivíduos ilustres, associados de Tibério, e Tubero irmão de Sejano, mas que foram liberados pela falta de fundamento desta associação. Mais ainda, após a tortura dos escravos de Sereno e a obtenção de uma confissão favorável à sua defesa, a plebe teria ameaçado linchar seu filho, que fugira imediatamente de Roma, mas foi apanhado em Ravena sob as instruções de Tibério e forçado a continuar o caso. É relevante notar que oito anos antes Víbio Sereno foi um dos acusadores de Marco Escribônio Libo Druso e que, insatisfeito com sua recompensa, escrevera para Tibério reclamando falta de reconhecimento por seus serviços.

No que tangeu à punição, Tibério vetara a sugestão de pena capital e a sugestão de Asínio Galo para que o condenado fosse enviado para Gyaros ou Donusa, ilhas sem água potável; Sereno fora então remanejado para Amorgos, onde estivera exilado até então ${ }^{579}$. Por outro lado, a morte de Cornuto levantou um debate sobre a formulação jurídica da lei de traição: caso acusados de traição cometessem suicídio antes da conclusão do julgamento, as recompensas aos acusadores deveriam ser abolidas. Contudo, Tibério se mostrou contrário ao Senado e objetou que tal mudança aviltaria as leis e minaria as fundações do estado: seria melhor dispensar as leis do que deter os seus guardiões ${ }^{580}$.

\footnotetext{
577 Víbio Sereno havia sido condenado em 22 ou 23 pela execução arbitrária de cidadãos romanos enquanto governador da Hispânia Ulterior, cf. Tácito, Anais, 4.13.

${ }^{578}$ Tácito, Anais, 4.28.1.

579 Idem, 4.28-30.

580 Ibidem, 4.30.1.
} 
Embora Tácito imediatamente qualifique ${ }^{581}$ tal precedente como pernicioso pelo encorajamento dos acusadores à busca de recompensas, podemos observar que tal fato evidenciou o crescimento da desconfiança do Princeps em relação à sua própria segurança, condição que gradualmente o distanciava da anterior postura em amenizar possíveis excessos na aplicação das leis ${ }^{582}$. Como no caso de C. Sílio e Sósia Gala, esta postura provavelmente teve forte relação com a influência de Sejano, e é um indício de como a aplicação da lei sofreria abusos a partir do momento em que não estivesse mais fiscalizando os procedimentos do Senado, após o seu afastamento para Capri.

Por último, a acusação de Cremúcio Cordo ${ }^{583}$ demonstrou uma investida direta do prefeito da guarda sobre um aristocrata que, embora não estivesse diretamente vinculado ao núcleo familiar de Agripina, foi um opositor declarado de Sejano. Cremúcio Cordo foi acusado de ter elogiado Bruto e Cássio, assassinos de Júlio César, e declarado inclusive que Cássio fora o último dos romanos. Sátrio Segundo e Pinário Nata, seus acusadores, eram clientes de Sejano, e a inimizade de Cordo com este último teria sido a real causa de sua eliminação; após a reconstrução do anfiteatro de Pompeu em 22 d.C. ${ }^{584}$, em que uma estátua de Sejano foi erguida em honra aos seus préstimos, Cordo lamentara publicamente que o monumento de um grande comandante estava sendo degradado com a imagem de um soldado desleal.

Conquanto estas críticas tenham feito com que Tibério se tornasse hostil a Cremúcio Cordo, outras razões podem ser conjeturadas. Como defensores da República, Bruto e Cássio em certa medida representavam um sistema político que deixou de existir a partir de Augusto; Tibério estava vinculado a este processo, independente de seu posicionamento político ter ou não proximidade com estes elementos republicanos.

Contudo, uma plausível sensibilidade a estes questionamentos teria se agravado com a junção de possíveis implicações ou desdobramentos diante destas críticas, que de um comentário aberto passaram a ser consideradas como ofensas pessoais ao Imperador. Após ter afirmado que não havia tecido

\footnotetext{
${ }^{581}$ Tácito, Anais, 4.30.1-2.

582 SEAGER, 2005, p. 164.

${ }^{583}$ Tácito, Anais, 4.34; Suetônio, Vida de Tibério, 61.3; Dion Cássio, 57.24.2.

${ }^{584}$ Tácito, Anais, 3.72.
} 
nenhuma crítica ao Princeps ou membro da família imperial - o que seria abarcado como crime de traição -, mas mencionado apenas republicanos, e ter feito uma defesa da liberdade política de expressão, Cremúcio Cordo deixou o Senado e cometeu suicídio ao morrer de fome; o Senado ordenou a queima de seus livros, embora alguns tenham sobrevivido para a posteridade ${ }^{585}$.

Além da acusação e suicídio de Cremúcio Cordo, o ano de 25 d.C. foi também marcado pelo pedido de casamento de Lívia Júlia feito por Sejano à Tibério. Tácito reproduz o conteúdo de uma correspondência enviada pelo prefeito da guarda ao Princeps e a resposta deste último ${ }^{586}$. Sua autenticidade é amplamente discutida pela historiografia ${ }^{587}$, embora Barbara Levick $^{588}$ argumente que a resposta de Tibério apresenta palavras e frases características do Princeps, levando a crer que ou Tácito emulou com maestria sua linguagem a ponto de criar um discurso condizente de seu autor, ou então preservou a fidedignidade de boa parte dos documentos consultados ${ }^{589}$.

De qualquer maneira, a correspondência apresentou um Sejano politicamente habilidoso: após ter remontado todos os benefícios e méritos concedidos a ele por Augusto e Tibério, sem desejar o esplendor de um cargo importante e tendo considerado a possibilidade de servir seu mestre uma recompensa suficiente, a principal honra desejável era a promessa de um vinculo matrimonial com a casa imperial, cujo referencial partira da iniciativa de Augusto em casar sua filha Júlia com um equestre; no caso de Lívia Júlia, Sejano desejava que o Princeps pudesse lembrar-se de seu amigo, sobretudo para que seus filhos fossem protegidos das investidas de Agripina ${ }^{590}$.

\footnotetext{
${ }^{585}$ Tácito, Anais, 4.35.4-5.

${ }^{586}$ Tácito, Anais, 4.39-40.

${ }^{587}$ Cf. SYME, 1955, p. 404. A nosso ver, um dos mais importantes referendos sobre o assunto, Syme questiona veementemente a credibilidade do relato taciteano: "Seianus rose to such a pinnacle that one of two things must ensue - supremacy or catastrophe. The outcome cast its shadow backwards over all that had gone before; and the story of criminal ambition could not appear but coherent and convincing. Thus adultery and poison in 23. And two years later the historian can report without misgivings a secret petition from Seianus to the emperor: he asked the hand of Drusus' widow. Tacitus might have felt prompted to enquire whether such high aspirations are likely to have taken firm shape so early". ${ }^{588} 1999$, p. 130.

${ }^{589}$ Sobre a consulta às atas senatoriais, cf. WELLESLEY, 1954, p. 13. Sobre o estilo discursivo atribuído a Tibério e apresentado por Tácito, cf. MILLER, 1968, p. 14: este autor enfatiza uma predileção de Tibério por uma vinculação ao vocabulário ciceroniano (carregado de arcaísmos), ao passo que os termos de Tácito ajudam a construir a impressão de um personagem reticente, moroso. Deste modo, uma discrepância de estilo é perceptível nas falas atribuídas ao Imperador ao longo da narrativa.

590 Tácito, Anais, 4.39.
} 
Este interesse confirma a suposição de que Sejano pretendia alçar-se como guardião de Tibério Gemelo, sendo particularmente notável a maneira como a exclusão de Nero, Druso e Agripina apresentou-se como uma tarefa a ser empreendida, e como se este núcleo familiar não fizesse mais parte da dinastia. Todavia, Tibério ainda não havia se manifestado contrariamente ao demonstrado perante o Senado em 23 d.C., o que nos leva a crer que Nero e Druso ainda estavam no plano sucessório. Curiosamente, Júlia Livilla, irmã de Tibério Gemelo, estava prometida a Nero, e provavelmente ela não seria exatamente um "alvo" de Agripina: não há qualquer menção a este fato.

Igualmente, é difícil não especular se Sejano não desejava um filho de seu casamento com Lívia Júlia, e que poderia talvez vir a tornar-se um Princeps: a nosso ver, caso Sejano ascendesse como guardião e esposo de Lívia Júlia, não haveria garantias precisas de que Tibério veria seu neto tornarse Imperador, principalmente após seu falecimento. De toda maneira, Tibério recuou diante do pedido de Sejano. Inicialmente, Tibério respondeu de forma breve: reverenciou sua lealdade e demandou tempo para que a questão fosse discutida entre Lívia Júlia, Antônia e Lívia, embora a decisão final estivesse com a primeira; em relação à animosidade de Agripina, Tibério prometera falar abertamente, pois esta se agravaria caso o matrimônio de Lívia Júlia repartisse a família imperial em facções (partes).

Todavia, a segunda correspondência questionou a linhagem de Sejano: Lívia Júlia, que havia sido esposa de Gaio César e depois Druso Cláudio, jamais consentiria em envelhecer ao lado de um equestre e, mesmo com o consentimento de Tibério, os mais ilustres cidadãos romanos não tolerariam este fato; embora não desejasse promoção social, haveria aqueles que criticariam o Princeps e a permissividade de tamanha ascensão ${ }^{591}$. Por último, embora não se opusesse à decisão final de Sejano ou Lívia Júlia, Tibério deixou claro ao prefeito da guarda que tinha planos futuros para estreitar vínculos entre ambos, mas que deixaria para anunciá-los futuramente, diante do Senado ou publicamente ${ }^{592}$. De acordo com Robin Seager ${ }^{593}$, acreditamos

\footnotetext{
591 Tácito, Anais, 4.40.

592 Idem, 4.40.7.

593 2005, p. 167.
} 
que a promessa feita por Tibério de promover a carreira de Sejano, embora bastante vaga, foi sincera.

De modo semelhante à maneira como associados, clientes e parentes que também obtiveram uma posição de importância dentro do governo, o prefeito da guarda devia sua posição ao favorecimento do Princeps, e seu futuro dependia da manutenção deste vínculo de lealdade. Não podemos determinar se Tibério tinha conhecimento de algum envolvimento prévio entre este último e Lívia Júlia, mas, por outro lado, a desconfortável recepção entre os indivíduos da aristocracia senatorial é um argumento bastante plausível, e Agripina poderia de fato se tornar um incômodo ainda maior para Tibério, perspectiva que definitivamente não parecia agradá-lo.

Contudo, é extremamente difícil crer que o Princeps não se posicionaria diante de um possível enlace que, sem dúvida, traria grande impacto dentro da família imperial, e as objeções feitas por Tibério a Sejano foram bastante claras: quanto à posição social, nada poderia ser feito a não ser esperar por uma promoção política que reforçasse sua posição de influência. Por último, em relação à intervenção de Agripina, embora o Princeps não tenha oferecido solução, uma ligação era evidente e presente na mente de Sejano: Agripina era um obstáculo e, portanto deveria ser eliminado.

Todavia, não cremos que se tratava de um estratagema que tinha Sejano como um joguete; a irresolução de Tibério aumentava à medida que este se tornava cada vez mais receoso do ambiente político em sua volta, e é plausível que o Princeps não estivesse seguro quanto às suas escolhas: a possibilidade de deixar com que Nero adquirisse autonomia sozinho, ou a conveniência de deixar que um intermediário como Sejano regesse o caminho do futuro príncipe em sua ausência, fato que poderia provocar uma cisão na dinastia ${ }^{594}$.

Embora Nero e Druso fossem os prováveis candidatos à sucessão imperial, o ambiente político dentro da residência imperial estava se tornando cada vez mais acrimonioso para o Princeps. Sejano teria se aproveitado da situação para ampliar o mal-estar nas esferas públicas e privada; a corte imperial tornara-se um foco perfeito para intensificar as dissidências. Tácito

${ }^{594}$ LEVICK, 1999, p. 130; SEAGER, 2005, p. 167. 
afirma ${ }^{595}$ que ele após a resposta de Tibério, Sejano não mais tocara no assunto, mas em contrapartida protestou contra silenciosas suspeitas, os rumores públicos, e o crescente ressentimento; e para que Tibério não diminuísse seu poder com o fim dos encontros em sua residência, mas também não alimentasse os interesses dos acusadores, Sejano começou a sugerir ao Princeps que usufruísse seu tempo em lugares mais atrativos fora de Roma.

Para Tácito ${ }^{596}$, Sejano antevia no convencimento de Tibério muitas vantagens: o acesso ao Princeps estaria em suas próprias mãos, ele poderia também se tornar responsável por selecionar a maior parte das correspondências, pois estas vinham pelas mãos dos soldados, e devido à idade avançada de Tibério, sua vida seria suavizada pelo isolamento do lugar, favorecendo finalmente a abdicação das responsabilidades do comando. Mais ainda, para si mesmo haveria menos aborrecimento com a exclusão dos aduladores que, removidos, permitir-lhe-iam um real ganho de poder. Sejano começara a censurar paulatinamente a Cidade de Roma e sua multidão, exortando as vantagens de uma solidão tranquila, ausente de aversões e afrontas, e onde assuntos mais importantes poderiam ser conduzidos ${ }^{597}$.

Era evidente que Sejano desejava isolar o Princeps politicamente, utilizando o distanciamento físico da Cidade de Roma como pretexto para interferir nas interações com a aristocracia e, sobretudo, para aplacar seus adversários dentro da corte imperial. Em contrapartida, da parte de Tibério e de seu visível cansaço com o ambiente na Capital, um incidente ao final de 25 d.C. parece ter contribuído para acelerar sua decisão. Tácito afirma ${ }^{598}$ que o caso envolvendo Votieno Montano levou Tibério a acreditar que ele deveria realmente evitar os encontros com o Senado.

O celebrado orador foi acusado de insultar Tibério, e Emílio (provavelmente membro da guarda pretoriana) foi bastante explícito em repetir com detalhes tudo o que Montano teria alegado, conquanto os senadores tivessem se esforçado para mantê-lo quieto. Como no caso de Grânio Marcelo ${ }^{599}$, Tibério teria novamente se irritado a ponto de declarar que

\footnotetext{
${ }^{595}$ Tácito, Anais, 4.41.1-2.

${ }^{596}$ Idem, 4.41.2-3.

${ }^{597}$ Ibidem, 4.41.3.

${ }^{598}$ Ibidem, 4.42.1.

${ }^{599}$ Ibidem, 1.75.2.
} 
rebateria as acusações imediatamente ou durante o interrogatório, e somente após súplicas de seus associados e dos demais teria conseguido se recompor, e Votieno acabara condenado por traição ${ }^{600}$.

Neste sentido, o descompasso entre o Princeps e os senadores novamente teria se verificado com a repetição do mesmo impasse entre a posição soberana do Imperador e os limites da liberdade de expressão política senatorial, algo que se agravaria ainda mais com uma nova investida no quadro do já instável ambiente da corte imperial. No ano seguinte, Tácito afirma ${ }^{601}$ que, em meio ao abalo na residência do Princeps (provavelmente o autor faz referência ao pedido de casamento de Sejano ${ }^{602}$ ) o processo de eliminação de Agripina havia começado: Cláudia Pulcra foi denunciada sob a acusação de Domício Afer. Cláudia era filha de Marcela, (sobrinha de Augusto) e M. Valério Messala Apiano (cônsul em 12 a.C.), e prima segunda de Agripina, tendo sido viúva de Quintílio Varo, ao passo que Afer, ex-pretor e ansioso por ascensão política, atribuiu a ela a acusação de adultério com um certo Fúrnio (cuja origem é obscura) e traição por tentativa de envenenamento e feitiçaria contra o Imperador.

Igualmente relevante foi a reação de Agripina: exaltada com a acusação feita à Cláudia Pulcra, a primeira teria interpelado Tibério em meio a um sacrifício público ao Divino Augusto, acusando-o de perseguir os seus descendentes (ela sim uma descendente de Escribônia), estar consciente do risco que sua nora estava vivendo, e que o único crime de Pulcra - cuja penalidade também acometera Sósia Gala - era o de demonstrar respeito por sua pessoa. Desconcertado e irritado com o constrangimento público, Tibério se limitara a dizer enigmaticamente em grego (provavelmente em referência a alguma tragédia) que o fato de Agripina não ser uma rainha não significava que estava sendo perseguida ${ }^{603}$; Pulcra e Fúrnio foram condenados, ao passo que Afer foi aclamado publicamente pela sua habilidade oratória ${ }^{604}$.

Posteriormente, ao ter sido visitada por Tibério, Agripina teria suplicado ao Princeps que a permitisse aplacar sua solidão com um novo casamento: ela

\footnotetext{
${ }^{600}$ Tácito, Anais, 4.42.1-2.

${ }^{601}$ Tácito, Anais, 4.52.1.

${ }^{602}$ Cf. WOODMAN, 2004, nota 91, pg. 148.

${ }^{603}$ Tácito, Anais, 4.52.2-3; Suetônio, Vida de Tibério 53.1.

${ }^{604}$ Tácito, Anais, 4.52.3-4.
} 
ainda era nova o bastante para tal, e havia homens que se dignariam a receber a esposa de Germânico e seus filhos. Tibério a deixara sem resposta ${ }^{605}$. Nesse ínterim, Sejano teria orientado pessoas próximas ao circulo de Agripina a convencê-la de que seu envenenamento estaria sendo tramado, e que ela evitasse um banquete organizado pelo Princeps. Durante a ocasião Tibério percebera que Agripina não tocara na comida e, como teste, teria pegado uma fruta da mesa e oferecido a sua nora; Agripina repassara a fruta diretamente para um de seus escravos, o que fizera com que Tibério dissesse a Lívia que não seria surpresa se ele se tornasse mais severo com alguém que estivesse 0 incriminando por envenenamento ${ }^{606}$.

O desentendimento entre ambos adquiriu proporções significativas; analisemos a relação entre os três mencionados desencontros. A condenação de Cláudia Pulcra foi um golpe duramente sentido pela viúva de Germânico César, que por sua vez sucumbiu ao estratagema planejado por Sejano. Certamente sua investida foi um ataque político decorrente das conexões entre Cláudia e Agripina, cuja infrutífera intervenção ampliou ainda mais o mal-estar entre esta última e Tibério. Consideramos ainda um precedente nem tão longínquo: a tia de Cláudia Pulcra fora prometida para Otávio; seu primo de segundo grau foi Ápio Cláudio (que se associara a Júlia Augusta) em 2 a.C., e seu outro primo provavelmente fora Júnio Silano (estigmatizado por ser amante de Júlia Menor e pai do suposto filho concebido por ela durante o exílio).

Embora Agripina não tenha sido associada com as acusações em relação à Cláudia Pulcra, não seria implausível que Tibério desconfiasse das implicações políticas que o êxito de um suposto envenenamento poderia trazer para o futuro da casa imperial. Por não ser algo inconcebível, esta possibilidade provavelmente foi habilmente explorada por Sejano: Tibério havia experimentado as dificuldades de manter o poder e o controle sobre a casa imperial e a íntima relação desta com a aristocracia e o Senado; possivelmente quando o Princeps questionou a invectiva pública de Agripina - insinuando que ele poderia ser uma das razões de sua insegurança -, a aspereza de sua declaração pode ter significado a síntese de sua longa contrariedade contra as ambições de Júlia Augusta, seus falecidos filhos, Júlia Menor e a própria

\footnotetext{
${ }^{605}$ Tácito, Anais, 4.53.1-2.

${ }^{606}$ Idem, 54.1-2.
} 
Agripina, uma estória de inabilidade ou infortúnio em reger os tumultos e as disputas por poder dentro de sua própria domus.

Mais ainda, quando esta última solicitou a possibilidade de um novo casamento a Tibério, sua negativa demonstrou que este estava bastante consciente das implicações políticas de seu desejo. As viúvas imperiais eram uma ameaça política constante, e tanto o casamento de uma ou de ambas as irmãs poderiam conduzir ao acirramento das disputas que o Princeps temia para a sucessão imperial. Embora Tácito não associe nomes, a recente viuvez de Asínio Galo teria implicado em uma relação óbvia, e além do ressentimento que Tibério sentia por ele - por ter se casado com sua primeira mulher, Vipsânia - Galo era ambicioso o bastante para fortalecer ainda mais as ambições de Agripina (e tornar-se ou um parceiro ou rival de Sejano); o desdobramento da narrativa após 26 d.C. auxiliam nesta conclusão.

Por fim, o temor de envenenamento por parte desta última (sendo o evento narrado por Tácito plausível) é revelador, uma vez que a crença de Agripina na possibilidade de ser envenenada por seu próprio sogro demonstrou o alto grau de desconfiança perante o Princeps, cuja reação de testar os limites da própria nora deve ter contribuído para sepultar de uma vez por todas qualquer laço de apreço por ela: após este banquete, não há nenhuma outra menção de encontro pessoal entre ambos nos anos posteriores ao afastamento de Tibério ${ }^{607}$.

Finalmente, diante deste panorama, o Princeps resolveu retirar-se da Cidade de Roma: neste contexto, o que motivou seu afastamento foi a desarmonia manifestada no seio da família imperial, e que estava tornando-se publicamente evidente. Tácito afirma ${ }^{608}$ que, durante o período do incidente ocorrido no último banquete em que Agripina participara, um rumor se espalhara com a insinuação de que sua eliminação estava próxima: o Imperador não se atreveria a fazê-lo abertamente, mas estava buscando reclusão para realizar o ato.

A disseminação deste rumor não seria impensável, se considerarmos a impopularidade que Tibério fatalmente adquiriu ao longo dos anos, principalmente após sua parcimônia em relação à morte e o funeral de

607 BAUMAN, 1994, p. 146-9; LEVICK, 1999, p. 130-2; SEAGER, 2005, p. 169-171.

${ }^{608}$ Tácito, Anais, 4.54.2. 
Germânico César, e que mais uma vez reverberou diante de sua austeridade com a morte de Druso Cláudio; talvez sua preocupação excessiva com a moderação e a temperança tenham contribuído para a mitificação de um soberano distante e, portanto, impopular, argumento que avançaremos mais adiante $^{609}$.

Antes disso, Tibério ainda comparecera a outros encontros no Senado e atendera vários legados da Ásia que estavam pleiteando a construção de um templo ${ }^{610}$. Com sessenta e seis anos, oficialmente ele não contava com nenhum príncipe para apoiá-lo nas responsabilidades do Estado e, como pudemos observar no subcapítulo anterior, o Senado não se tornara mais apto a assumir seus próprios encargos do que no início de seu governo: a nosso ver, provavelmente Tibério se questionou sobre a necessidade de permanecer cotidianamente no corpo a corpo reiterando o prestígio de seus magistrados e a autonomia da instituição senatorial.

Por outro lado, Tibério contava com um colaborador que poderia manter sua segurança pessoal enquanto prefeito da guarda pretoriana, que poderia auxiliá-lo com as demandas da rotina administrativa na capital do Império, e que poderia inclusive aconselhá-lo como um cidadão que não estava obrigatoriamente vinculado ao Senado, embora galgasse uma posição que em breve o tornaria praticamente acima desta instituição. Os fatores que determinaram sua decisão não foram abruptos, e tampouco a conjuntura; o anseio de Tibério pelo afastamento não surgiu pela simples influência de Sejano (que provavelmente já existia antes do começo de sua ascensão ao poder), embora este tenha contribuído habilidosamente para tanto.

Contudo, veremos que a fadiga de Tibério em relação aos assuntos públicos e ao ambiente da casa imperial não foi decorrente apenas das manipulações de Sejano, pois mesmo após sua eliminação, o Princeps permaneceu em Capri até o fim de sua vida, aparentemente sem nenhuma séria pretensão de voltar para a Cidade de Roma e retomar os seus hábitos políticos anteriores, não obstante inúmeras vezes tenha frequentado os arredores da capital. Em 26 d.C., Tibério promoveu uma transformação no ainda incipiente ambiente político imperial: seu afastamento representou 0

${ }^{609}$ Cf. página 241.

${ }^{610}$ Tácito, Anais, 4.55-6. 
deslocamento do centro decisório da instituição do Principado, demonstrando simultaneamente que o poder estava de fato onde estava o Imperador, e que seu cerne encontrava-se, sobretudo, dentro da corte imperial. A transferência da corte imperial representará um momento de inflexão no governo de Tibério, e o principal experimento político de seu Principado. 


\section{CAPÍTULO III - O PRINCIPADO DE TIBÉRIO: OS ANOS EM CAPRI}

\section{1 - Por que Capri?}

Os anos de 26 e 27 d.C. abarcaram um importante acontecimento no governo de Tibério César: o Princeps e parte de sua corte imperial deslocaramse da Cidade de Roma para a ilha de Capri. Aparentemente, o fato em si não destoaria de um hábito comum da aristocracia senatorial romana, detentora de propriedades na costa italiana, e bastante acostumada a passar algumas temporadas entre a capital do Império e estas residências. Todavia, o aspecto peculiar do afastamento do Princeps do cerne do poder e da vida pública imperial resultou das prováveis intenções e das consequências deste movimento: Tibério não mais retornou para Roma, e em Capri passou o restante de seu governo e os últimos anos de sua vida.

A história sobre a ilha de Capri deve ser compreendida, mesmo que para os nossos propósitos apenas brevemente, no âmbito de uma perspectiva macrocontextual da região italiana da Campânia (originário do grego KappanoI), especificamente a partir do século II a.C., em um período em que a hegemonia romana na península já era incontestável (até então, gentílicos de origem grega e samnítica coabitavam a região em moldes relativamente similares aos povos itálicos oriundos do começo do século $\mathrm{V}$ a.C.). A região sempre se mostrou economicamente atrativa, principalmente no entorno da cidade de Cápua e notadamente em relação à agricultura, mas também interessante para artesãos, comerciantes e negociantes. Vale destacar também que, além de Cápua, Nápoles, Pompéia e Putéolos compuseram uma rede de integração econômica e social que, não por acaso, fora fonte de particular atenção da aristocracia romana, desde o final das guerras púnicas até a morte de Júlio César ${ }^{611}$.

Já durante as últimas décadas da República, em princípio a região foi fortemente espoliada para o patrocínio das campanhas de Otávio contra

${ }^{611}$ CASSOLA, 1991, p. 103-110, 118-20. 
Antônio. Contudo, antes mesmo da vitória no Áccio, o primeiro tentou reaproximar-se das comunidades concedendo benesses e construindo obras públicas. Tempos depois, já como Princeps, cidades como Avelino, Benevento, Nola e Putéolos receberam indenizações vultosas pela concessão de terras aos veteranos ${ }^{612}$. Miseno, anteriormente cobiçada como uma localidade adequada para a construção de villae e também próxima da cidade de Putéolos (que fora outro importante centro comercial italiano), tornara-se a partir de governo de Augusto um dos principais destacamentos da frota naval imperial, responsável pela proteção de praticamente toda a costa italiana, bem como um dos principais entrepostos comerciais recebedores de influxos do Egito, Oriente e da Trácia, e também um centro cosmopolita de comércio de bens locais e importados, para o qual confluíam indivíduos de inúmeras localidades provinciais.

Tempos antes, Augusto já havia adquirido propriedades nas proximidades de Roma, como em Lanúvio, Preneste e Tibur, embora Suetônio afirme ${ }^{613}$ que este Princeps não apreciava palácios por demais luxuosos, e tivesse adquirido um apreço especial pelo litoral e pelas as ilhas da região da Campânia. Semelhante atração pela natureza do local foi também recorrente em outros ilustres nomes da aristocracia anteriores à Augusto: Cipião Africano, Caio Mário, Lúcio Cornélio Sila e Cícero são exemplos da predileção destes homens pela região.

Entretanto, para além do relaxamento e do lazer, as propriedades que se constituíram durante o período imperial, e principalmente as que pertenceram à família imperial devem ser abarcadas dentro de um escopo maior que compusera uma série de estratégias de inovação e ajustes que disseram respeito às esferas econômica, cultural, social e militar durante o Principado. As ações políticas de Augusto para o desenvolvimento estratégico da Campânia estabeleceram um precedente que seria variavelmente seguido por seus sucessores: como durante o período republicano, a Campânia continuou a ser uma região particularmente importante para os romanos. Isto é perceptível no impacto que uma das mais importantes benfeitorias de Augusto, o aqueduto de Serino (Aqua Augusta) trouxe para a região, com uma extensão

${ }^{612}$ CASSOLA, 1991, p. 120-1.

${ }^{613}$ Vida de Augusto, 72.2. 
de mais de noventa e seis quilômetros, cujos reparos foram celebrados em uma inscrição que enumera em ordem de importância as localidades que teriam sido beneficiadas com o abastecimento de água: Putéolos, Neápolis, Nola, Atela, Cuma, Acerra, Baia e Miseno ${ }^{614}$. A circunspecção de Augusto tornou-se um precedente político para seus sucessores; a presença imperial, suas ações administrativas, obras públicas e benfeitorias não devem ser consideradas apenas como apelos pessoais pela região, mas como diretrizes da administração imperial estabelecidas com Augusto $^{615}$.

Em contrapartida, é bastante difícil encontrar comentários positivos sobre a ilha de Capri anteriores à ocupação imperial. Enquanto que Nápoles se tornou rapidamente o porto mais importante do Mar Tirreno, graças ao empreendedorismo de sua aristocracia grecocampânica que soube se adaptar a apoiar-se na reorganização administrativa romana, bem como sua posição geográfica que a tornou um dos principais escoadouros do mar mediterrâneo, é provável que Capri tenha permanecido pouco povoada, mantido uma pequena agricultura de subsistência, e sido administrativamente dependente de - e pouco relevante para - Nápoles até o governo de Augusto ${ }^{616}$.

A partir de então, e mais especificamente em 29 a.C., a ilha de Capri havia se tornado fonte de seu desejo, o que o impelira a adquiri-la dos neapolitanos, para os quais Enária (Ísquia) fora dada como compensação; Capri tornara-se sua propriedade privada e edificações ali começaram a ser construídas $^{617}$. E nesta ilha, ao invés de estátuas dispendiosas e afrescos, o Princeps preferira jardins e bosques para ornar suas villae, onde também antiguidades exóticas eram exibidas: ossos de mamute, de criaturas do mar e grandes feras selvagens, além das armas de grandes heróis ${ }^{618}$. Por último, antes de sua morte, Augusto passara quatro dias dedicados ao descanso e ao entretenimento de seus convidados em Capri; os romanos se vestiam com o pallium, enquanto os gregos se vestiam com a toga, e era seu costume assistir

\footnotetext{
${ }^{614}$ CÀSSOLA, 1991, p. 123-4; SGOBBO, I. Notizie degli Scavi di Antichitá, 1938, pp. 75-97, apud D'ARMS, 1970, p. 79.

${ }^{615}$ D'ARMS, 1970, p. 78-82.

${ }^{616}$ SAVINO, 1991, p. 417-20.

${ }^{617}$ Estrabão, Geografia, 5.4.9. Cf. D'ARMS, 1970, p. 73; HOUSTON, 1985, p. 179; SAVINO, 1991, p. 421-2.

${ }^{618}$ Suetônio, Vida de Augusto, 72.3.
} 
aos exercícios dos efebos gregos, bem representados em número na ilha, além de conceder banquetes em honra dos mesmos ${ }^{619}$.

De acordo com John D'Arms ${ }^{620}$, Augusto teria adquirido grandes propriedades nas imediações da baía de Nápoles e outras localidades da Campânia, conquanto nem todas as villae imperiais tivessem servido puramente para o lazer do Imperador. Como em relação ao envio de Júlia Augusta para a ilha de Pandatéria em 2 a.C., o exílio para as ilhas da Campânia tornara-se uma recorrente forma de punição infringida sobre os membros da família imperial. Por outro lado, as propriedades augustanas em Capri, Surrento, Pausílipos, Baia e Nola ajudam a corroborar a impressão de que fora em diversas localidades da costa da Campânia que o primeiro Imperador buscara algum tipo de alívio diante dos deveres do Estado.

Por sua vez, Savino acredita ${ }^{621}$ que o testemunho de Suetônio possui grande validade se inserido em um contexto mais ampliado do interesse do Princeps por Nápoles e pela Campânia, o que foi decisivo para a futura configuração da região dentro dos interesses administrativos imperiais. Mais do que mero lazer, e certo de que a beleza das paisagens naturais e a salubridade do clima também se constituíram como um grande atrativo, a presença de Augusto significou intensa atividade política e diplomática, de modo semelhante ao que ocorreria com o seu sucessor.

Passando para o governo de Tibério, Tácito afirma ${ }^{622}$ que em 26 d.C. 0 primeiro, tendo durante muito tempo considerado e do mesmo modo frequentemente adiado seu plano, finalmente teria se retirado para a região da Campânia, com o intuito de dedicar templos a Júpiter em Cápua e a Augusto em Nola, conquanto tenha por fim se fixado longe de Roma, não obstante Tibério tenha se mantido a postos para retornar, bem como enviara correspondências a este respeito, e durante seus últimos ainda passara

\footnotetext{
${ }^{619}$ Suetônio, Vida de Augusto, 98.1-3.

620 1970, p. 77-9. Savino acredita (1991, p. 422) que o testemunho de Suetônio possui grande validade se inserido em um contexto mais ampliado do interesse do Princeps por Nápoles e pela Campânia, o que foi decisivo para a futura configuração da região dentro dos interesses administrativos imperiais. Mais do que mero lazer, a presença de Augusto significou intensa atividade política e diplomática.

621 1991, p. 422.

${ }^{622}$ Anais, 4.57.1; Suetônio, Vida de Tibério, 40.
} 
também tempo em localidades próximas do litoral ou mesmo instalado nas proximidades dos muros da capital ${ }^{623}$.

Em consideração às razões que levaram ao afastamento do Princeps, Tácito afirma ${ }^{624}$ que, embora tenha seguido a opinião da maior parte dos autores e atribuído o fato às ações de Sejano, em virtude dos seis anos posteriores em que Tibério continuara na ilha, mesmo após a eliminação do primeiro, este autor acredita que a real motivação de seu distanciamento originara-se dos próprios desígnios do Imperador, que desejava esconder sua ferocidade e sua devassidão. Tácito também argumenta ${ }^{625}$ que houve aqueles que acreditavam que Tibério incomodara-se profundamente com sua aparência física resultante da velhice (apesar de ter continuado esguio, apresentava calvície e o rosto coberto por pústulas, que eram tratadas com cosméticos), e como durante seu exílio em Rodes, ele evitara encontros e preferira dar vazão aos seus prazeres.

De modo semelhante, Tácito ainda complementa ${ }^{626}$ que ele fora vencido pela intransigência de sua mãe, a quem Tibério rejeitara a interferência política conquanto não pudesse demovê-la de sua posição pela influência que the assegurara a proeminência na ascensão ao Principado; teria sido ela que evitara que Germânico César, preferido de Augusto e do povo romano assumisse o poder, e que implorara para que o falecido Princeps associasse Tibério como seu pai adotivo: estes teriam sido os argumentos que justificaram as constantes reclamações de Lívia a seu filho e os seus pedidos por compensação.

A comitiva que acompanhara Tibério em seu afastamento para Capri teria sido bastante pequena. Tácito afirma ${ }^{627}$ que nesta estavam presentes um senador e ex-cônsul, Coceio Nerva; além de Sejano, outro proeminente equestre chamado Cúrtio Ático (eliminado pelo primeiro anos depois), e o restante composto por indivíduos versados nas artes liberais, em sua maior parte gregos. Nesse ínterim, astrólogos teriam dito ao Princeps que as motivações de seu afastamento possuíam algo em comum com os movimentos

\footnotetext{
${ }^{623}$ Tácito, Anais, 4.58.3; Dion Cássio, 58.1.1.

${ }^{624}$ Anais, 4.57.1.

${ }^{625}$ Idem 4.57.2.

${ }^{626}$ Ibidem, 4.57.3.

${ }^{627}$ Ibidem, 4.58.1.
} 
dos planetas, e que da mesma maneira estes lhe negavam o retorno para Roma; esta teria sido a motivação para a eliminação de tantos indivíduos que predisseram e tornaram públicas as expectativas para seu rápido fim, embora nenhum deles tivesse previsto o fato de que Tibério permaneceria os próximos onze anos de sua vida longe por opção ${ }^{628}$.

Suetônio aponta ${ }^{629}$ que Capri teria atraído o Imperador em razão da dificuldade de acesso: repleta de rochedos íngremes e penhascos, e rodeado por um mar profundo, uma pequena praia era a única forma possível de entrada na ilha. Tácito reitera ${ }^{630}$ estes critérios: Capri posicionava-se a quase cinco quilômetros da parte mais alta da costa, em meio a um mar bastante agitado, sem refúgios para o atraque de embarcações; e era praticamente impossível aproximar-se da ilha sem o conhecimento da guarda imperial.

E teria sido durante este período que Tibério se deparara com um fato que intensificara os rumores sobre sua longevidade e sua confiança em relação à Sejano: em um banquete oferecido pelo Princeps em uma villa chamada Espelunca (Sperlonga), construída em meio às rochas e em uma caverna, subitamente ocorrera um deslizamento que espalhara o pânico entre os convivas presentes; Sejano lançara-se sobre Tibério e o protegera das rochas com o próprio corpo, tendo sido posteriormente descobertos pelos soldados que vieram socorrê-los. Este fato teria ampliado ainda mais a confiança do Princeps em relação ao prefeito da guarda ${ }^{631}$.

Durante o período de seu afastamento, Tibério teria lançado um edito que proibia qualquer um de interromper sua paz, fazendo com que os habitantes das localidades próximas fossem mantidos à distância pelos soldados $^{632}$. Entretanto, pouco tempo após ter se instalado em Capri, Tibério tivera de retornar para a costa italiana em decorrência de um terremoto na cidade de Fidenae ${ }^{633}$. Suetônio afirma ${ }^{634}$ que as imprecações da população diante deste desastre obrigaram-no a aparecer novamente. Mais ainda, este

\footnotetext{
628 Tácito, Anais, 4.58.2.

629 Vida de Tibério, 40.

630 Anais, 4.67.2.

631 Tácito, Anais, 4.59.1-2.

632 Idem, 4.67.1.

633 Ibidem, 4.62-3.

634 Vida de Tibério, 40.
} 
autor complementa ${ }^{635}$ que ao finalmente regressar para a ilha, consequentemente Tibério negligenciara a condução dos assuntos públicos, nunca mais tendo preenchido as vagas das decúrias, substituído os tribunos militares ou os governadores de quaisquer províncias; o Princeps deixara a Hispânia e a Síria sem governadores por vários anos, permitira que a Armênia fosse varrida pelos partas, a Moésia assolada pelos dácios e sármatas, bem como as Gálias pelos germanos. Conforme observaremos adiante, há certo exagero da parte de Suetônio, embora de fato tenha sido uma das características de Tibério a longa permanência de governadores de províncias e outros postos de confiança nas mãos de poucos associados do Princeps.

O distanciamento e a crescente impopularidade de Tibério permitiram com que uma amplitude de rumores e estórias sobre sua conduta privada fosse tecida pela tradição romana. Embora Tácito e Dion Cássio eventualmente tenham se valido da enumeração dos rumores e boatos em suas narrativas, os "segredos" da corte imperial recebem enorme importância da parte de Suetônio. Neste sentido, Tibério teria adquirido a esperada liberdade para dar vazão aos seus vícios; Capri teria sido um lugar adequado para as orgias secretas do Imperador, com devassos de ambos os sexos especializados em sodomia e depravação, e que fornicavam em trios para estimular suas paixões $^{636}$.

Seus aposentos teriam sido decorados com as mais impudicas pinturas e esculturas, bem como uma livraria composta de manuais eróticos cujas posições eram executadas por um ator caso fosse necessário; crianças vestidas de ninfas e pans (divindade grega protetora dos pastores) posicionadas em recantos e preparadas para intercursos que justificavam o nome do lugar como o jardim do bode velho ${ }^{637}$. Mais ainda, a morte de uma matrona senatorial chamada Malona teria revelado o seu hábito de abusar sexualmente de mulheres: uma vez que ela se recusara a se submeter ao Princeps, este teria feito com que fosse denunciada por acusadores no

\footnotetext{
635 Suetônio, Vida de Tibério, 41.

636 Vida de Tibério, 42.1.

${ }^{637}$ Suetônio, Vida de Tibério, 44.1-2.
} 
Senado, o que consequentemente fizera com que esta mulher cometesse 0 suicídio pela desonra provocada ${ }^{638}$.

Certamente o afastamento de Tibério do contato presencial com a população de Roma - em seus diversos segmentos sociais - contribuiu para estimular toda uma construção alegórica do comportamento privado do Princeps, e é impossível distinguirmos o que é crível daquilo que é fantasioso dentro de todo um conjunto de estórias de perversões e extravagâncias sobre ele. Todavia, se autores como Suetônio foram hábeis em explorar estas facetas de seus personagens e exista uma tônica narrativa que evidencie a crueldade do soberano, em boa parte dos relatos sobre este Imperador observamos evidências que apontam para a exasperação de Tibério diante de qualquer ameaça de invasão de sua privacidade.

$\mathrm{O}$ anterior afastamento para Rodes pode ter contribuído em certa medida para fomentar críticas sobre a maneira como Tibério lidava com as pressões políticas e pessoais. Ressentimento ou frustração podem ter sido perfeitamente confundidos com arrogância, lugubridade ou devassidão, percepções inflamadas ao longo dos anos pela maneira como o Princeps lidara com os acontecimentos mais conflituosos de seu governo, sobretudo em relação ao comportamento da família imperial. De todo modo, é bastante difícil atribuir as causas para o afastamento de Tibério a apenas um ou outro motivo, conforme nos é apontado pela documentação, e tampouco há consenso entre os próprios autores.

Como pudemos observar até o presente momento, os fatores que podem ter compelido o Princeps à resolução de que o afastamento do cotidiano público e privado em Roma apareceram pontual e gradualmente ao longo dos primeiros anos de seu governo. Sendo assim, já durante o começo de seu Principado, Tibério sinalizara algum interesse na possibilidade de que um dia ele pudesse ser aliviado de seu fardo, das responsabilidades do posto político alcançado $^{639}$.

E embora os reveses administrativos e militares não tenham sido graves o bastante para comprometer a impressão de que a administração imperial durante seu governo tenha operado dentro de uma perspectiva de continuidade

\footnotetext{
${ }^{638}$ Suetônio, Vida de Tibério, 45.

${ }^{639}$ Tácito, Anais, 1.11.1.
} 
ao período de seu predecessor, para este Princeps seus deveres tornaram-se cada vez mais fastidiosos, especialmente diante de sua frustração com sua política de promoção da iniciativa e autonomia do Senado, da intensificação das acusações e condenações por traição, especialmente aquelas envolvendo direta ou indiretamente a sua própria imagem, e principalmente pela acrimoniosa relação pessoal e política que fora se constituindo ao longo dos anos entre ele e o núcleo familiar de Germânico César e Agripina; a morte de Druso César e as complicações oriundas da pré-concebida estratégia de sucessão dinástica engendrada por Augusto trouxeram esgotamento para um Princeps que aparentemente começara a ver sua posição de pater familias ameaçada dentro da residência imperial, e o ambiente de intrigas, disputas e conflitantes relações de poder dentro da corte não contribuíram para que houvesse alguma forma de alívio para esta situação em Roma.

Do mesmo modo, em 26 d.C. Tibério teria completado setenta anos de idade; a morte de vários de seus amigos, associados e interlocutores políticos gradualmente contribuiu para deixa-lo cada vez mais isolado, condição que fora parcialmente remediada pelo suporte de Sejano. Contudo, em certos aspectos o afastamento lhe foi pernicioso, uma vez que observaremos que a anterior disposição exercida na avaliação criteriosa de seus deveres públicos e sua observância no comprometimento com os afazeres senatoriais foi sendo reconduzida - em decorrência de sua crescente credulidade para com a palavra de Sejano - para uma grande desconfiança em relação à sua posição política e integridade física, uma perene contradição entre o desejo de possuir companhia (mais de uma vez Tibério visitara o continente, passando vários dias em outras propriedades na costa) e permanecer sozinho (o que se observara mediante $\mathrm{o}$ edito promulgado coibindo perturbações e sua incapacidade de adentrar em Roma).

Nesse sentido, o afastamento de Roma indicara um problema, um elemento que contribuíra para constatarmos que esse movimento constituiu-se como um momento de inflexão política durante o seu Principado: um dos principais aspectos do governo de Augusto foi a ativa participação - e suas consequências - do Princeps no âmbito das deliberações senatoriais, fato particularmente importante para o contexto de experimentação e confirmação de seus poderes no período imediatamente subsequente ao fim da República. 
Isto permanecera durante o governo de Tibério em seus primeiros anos; com o afastamento do Princeps, sua participação e as deliberações in loco foram substituídas por instruções em correspondências, o que ao mesmo tempo pode ter sido mais intimidador para certa parcela dos senadores, enquanto que para outros membros ampliara ainda mais a desmotivação para o debate, bem como permitira ainda que vários se utilizassem da ausência do Imperador como maneira para explorar possibilidades nas acusações e condenações por traição.

E dentro deste contexto, em um primeiro momento Sejano conseguira alavancar sua ascensão; Tibério tornou-se cada vez mais dependente das informações por ele trazidas e de acordo com suas intenções, e o prefeito da guarda obtivera liberdade para executar seus desígnios sem receio de ser imediatamente coibido ou punido pelo Princeps. Igualmente, tornara-se mais fácil para Sejano fazer com que o ressentimento oriundo de suas ações recaísse diretamente sobre Tibério e possivelmente isolá-lo ainda mais daqueles que poderiam alertá-lo sobre as iniciativas do primeiro, e vice-versa; como exemplo, a despeito do fato de que a sistemática eliminação do núcleo familiar de Agripina fora engendrada por Sejano, Tibério não se vira imune ao impacto negativo que as consequências das ações do primeiro trouxeram para a sua reputação $0^{640}$.

Retornemos então para a pergunta que intitula este subtópico. É importante ressaltarmos que 0 afastamento de Tibério para a ilha de Capri não significou que o Princeps permanecera absolutamente isolado, e que todos os seus anos restantes em sua corte lá estabelecida representaram um rompimento completo com o estilo de vida adquirido em Roma. É mais correto dizer que, entre 27 e 37 d.C., o conjunto de villae constituídas em Capri tornaram-se - além da residência oficial do Imperador - o cerne de onde emanou as decisões últimas sobre as principais questões deliberativas que regeram o Império Romano. As peculiaridades da ilha acabaram por estabelecer um filtro no que diz respeito às interações sociopolíticas entre soberano e seus governados, e junto a isso diversas conseqüências que temos acompanhado neste trabalho. $E$ enquanto residência, centro político e

${ }^{640}$ SHOTTER, 2004, 67-8. 
administrativo, e também enquanto uma típica propriedade aristocrática da região da Campânia, Capri deve ter contado com a presença de uma corte, que abarcara desde membros da família imperial até libertos, escravos e demais funcionários que compunham a estrutura do palácio, em moldes semelhantes aos de Roma.

Tácito afirma ${ }^{641}$ que outrora os gregos teriam sido os arrendatários da ilha e que esta havia sido habitada pelos Teléboas ${ }^{642}$, embora tivesse sido Tibério quem transformara a localidade mediante a construção de doze grandes e atrativas villae. Provavelmente algumas delas teriam sido remodeladas e adaptadas para comportar o quantitativo de pessoas e as necessidades de todos que vieram com a corte imperial, embora outras tivessem sido construções novas, como a Villa lovis, que é mencionada por Suetôni ${ }^{643}$ no contexto da eliminação de Sejano: após sua morte, Tibério teria ficado quase nove meses sem sair desta villae.

Os resquícios arqueológicos encontrados no sítio de Capri demonstram que a estrutura arquitetônica imperial existente durante o período deste Princeps era ampla: além da grande quantidade de edifícios, muitos deles eram bastante grandes: os mais de cinco mil metros quadrados da residência do Imperador em Capri representavam mais que um terço do tamanho da Domus Tiberiana na Cidade de Roma, com a exceção das construções posteriores ao seu período, conquanto devam ser também adicionados os jardins e construções anexas à morada principal de Tibério na ilha, ou mesmo as demais residências construídas, se compartilharmos do pressuposto de que toda a ínsula era por princípio a residência imperial deste Princeps ${ }^{644}$.

Posteriormente, entre os séculos XVIII e XIX, as ruínas da ilha de Capri, situadas em meio a inúmeras outras ruínas ou construções medievais e modernas, foram desordenadamente exploradas e catalogadas; as pilhagens e a falta de zelo dos primeiros esforços arqueológicos até quase o primeiro terço do século XX dificultam e muito os atuais esforços que visam constituir reaproximações de seu traçado original. Entre as doze construções que foram

\footnotetext{
${ }^{641}$ Anais, 4.67. 2-3.

${ }^{642}$ Sobre a tradição mítica grega e a origem da ilha de Capri, cf. FEDERICO, 1998, p. 383-89.

${ }^{643}$ Vida de Tibério, 65.2.

${ }^{644}$ HOUSTON, 1985, p. 180.
} 
relacionadas às evidencias históricas mencionadas, a mais importante foi a construção relacionada à atribuição oferecida por Suetônio.

Neste sentido, a Villa lovis, estabelecida no promontório oriental da ilha (o chamado "Monte Tibério") e a 334 metros do nível do mar, é a edificação que possui a mais grandiosa arquitetura no conjunto dos resquícios arquitetônicos encontrados. Amadeo Maiuri afirma ${ }^{645}$ que o posicionamento das ruínas da residência de Tibério expressam uma vontade de dominação, uma necessidade de defesa, ou mesmo um desejo de descanso e relaxamento: os resquícios de sua construção seriam indícios de sua personalidade sombria e de seu desejo de solidão ${ }^{646}$. A despeito deste posicionamento romântico, é interessante o argumento de que Tibério (ou seus encarregados) teria tido uma interessante percepção arquitetônica, o que nos leva a imaginar um edifício que simultaneamente combinou a impressão de uma fortaleza encravada nas rochas, um lugar ermo ou um castelo, mas também de um refúgio aprazível pela presença de enormes aposentos e terraços ajardinados ${ }^{647}$.

Clemens Krause afirma ${ }^{648}$ que a construção da residência imperial de Tibério em Capri foi o resultado de uma combinação entre o interesse por seu posicionamento geográfico, a peculiaridade de sua topologia (uma vez que o edifício que servira como morada a Tibério posicionara-se na parte mais alta da ilha), e o desejo de fazer desta morada um ambiente de grande requinte. Consequentemente, estes fatores culminaram em uma construção arquitetônica bastante singular, pois sua planta foi concebida na tentativa de conciliar o relevo do terreno e a paisagem ${ }^{649}$. Além disso, tanto a Villa lovis quanto a Domus Tiberiana apresentam grande similaridade em suas fundações; e por esta última ter sido posterior à construção da residência de Tibério em Capri, o seu projeto teria sido uma influência decisiva para a fundação do novo palácio imperial em Roma, empreendida em diferentes fases, e cujas expansões só terminaram durante o governo de Domiciano.

Além das motivações políticas que fizeram com que Tibério se afastasse de Roma, a escolha de Capri como morada dificilmente teria sido considerada

\footnotetext{
645 1956, p. 32-3.

${ }^{646}$ Conferir anexo.

647 MAIURI, 1956, p. 34-6.

648 2005, p. 259-61.

${ }^{649}$ Conferir anexo.
} 
algo incomum durante o período, uma vez que sair de Roma e deslocar-se para alguma propriedade na região da Campânia era um hábito comum da aristocracia. Por volta do último século do período republicano, uma boa parte de seus membros possuía alguma residência nesta imediação e frequentemente as visitavam: além das belas paisagens, a Campânia apresentava uma efervescência intelectual, o que se refletia nas atividades daquelas que costumavam passar temporadas no local.

Como evidenciamos acima em relação às motivações sobre a aquisição da ilha de Capri por Augusto, a costa italiana representava uma alternativa de fuga das pressões do cenário político da cidade de Roma, um ambiente de filósofos e passatempos literários, perambulando entre várias outras propriedades, bem como pescaria e alívio para o corpo em estâncias termais, banhos em águas sulfurosas (tidas como medicinais) ou passeios em cavernas e jardins. A presença de várias construções em Capri também pode ser considerada como indício da predileção de Tibério por, assim como Augusto, também frequentar diversas propriedades diferentes, atitude que se repetiu em suas demais jornadas na Itália, permeada por estadias em villae imperiais em Surrento, Túsculo, Antio, e Miseno ${ }^{650}$.

Em outros termos, frequentar a região da Campânia e seu litoral constituiu-se como uma distração aristocrática que combinava lazer, arte, vida intelectual e eventos sociais que se opunham às pressões políticas e sociais tão características na capital do Império ${ }^{651}$ : as atividades privadas de Tibério

650 Cf. ROGERS, 1945, p. 42-4: Tibério retorna ao continente para atender as demandas oriundas do desabamento de um anfiteatro em Fidenae (Tácito, Anais, 4.62, 4.67.1; Suetônio, Vida de Tibério, 40), embora sem maiores detalhes sobre sua estadia; em 28 d.C., em meio à revolta dos Frísios, Tibério teria se aproximado de Surrento (Tácito, Anais, 4.72-74.2); em algum momento antes da morte de Lívia, Tibério teria a visitado, mesmo que durante poucas horas (Suetônio, Vida de Tibério, 51.2); em 32 d.C., o Princeps se aproximara de Roma, tendo inicialmente passado por Surrento e pela costa de outras cidades próximas (Tácito, Anais, 6.1.1; Suetônio, Vida de Tibério, 65.2); em 33 d.C., Tibério novamente se aproximara de Roma com o intuito de arranjar o matrimônio para as filhas remanescentes de Germânico e Druso César, e possivelmente estivera em Antio dois anos mais tarde, onde fora celebrado 0 casamento de Gaio César (Dion Cássio, 58.21.1, 58.25.2; Tácito, Anais, 6.15.4-6, 6.20.1, 6.27.1); em 34 d.C., Tibério teria permanecido algum tempo em Túsculo, mas não adentrara Roma para celebrar o segundo decênio de poder (Dion Cássio, 58.24.1); em 36 d.C., Flávio Josefo afirma (18.161 apud ROGERS, 1945, p. 43) que após receber o rei Herodes Agripa em Capri, este último teria sido denunciado por um liberto enquanto ambos viajavam pela Itália, nas imediações de Túsculo; e em 37 d.C., já com a saúde bastante debilitada, Tibério teria feito sua última viagem, tendo falecido em Miseno (Tácito, Anais, 6.50.2; Suetônio, Vida de Tibério, 72-3.1).

${ }^{651}$ D'ARMS, 1970, p. 45, 129-32; HOUSTON, 1985, p. 180. 
após seu afastamento para Capri em muito se assemelharam aos tradicionais afazeres de seus pares. Embora sem apontar o contexto, Suetônio afirma ${ }^{652}$ que o Princeps era dedicado aos estudos literários tanto em latim quanto em grego; Tibério teria composto um poema lírico dedicado a Lúcio César, recebia comentários ou dedicações nas obras de outros autores, e costumava travar disputas sobre mitologia com gramáticos. Igualmente, em sua autobiografia, cuja menção por Suetônio ${ }^{653}$ tem como pretexto apontar as razões pelas quais ele punira Sejano, acreditamos que o ato de sua composição tivera como plano de fundo seus exercícios literários em Capri, o que de certo modo corrobora o argumento de que como os demais aristocratas romanos, sua permanência na ilha fora permeada por estas distrações.

Em termos mais amplos, a empatia de Tibério pelas referências da cultura grega inseriu-se no âmago da natureza conservadora concernente à aproximação dos romanos em relação à mesma. Conforme ocorrera durante o período republicano, a aproximação junto ao helenismo era permissível, mas a atitude de abandonar completamente os hábitos e obrigações típicas de um cidadão romano em favor dos costumes gregos era uma inconsistência extremamente malvista.

Diante deste panorama, o primeiro exílio de Tibério para Rodes já demonstrara o interesse do Princeps pela cultura grega. Durante o posterior período em que permaneceria em Capri e nos arredores da Campânia, este estivera rodeado por intelectuais gregos, manifestando cotidianamente seu profundo interesse pela filosofia, pela língua e pela mitologia, e a sua empatia por estes elementos culturais provavelmente foi mais proeminente do que nos demais Césares da dinastia ou membros da família imperial. A conduta de Tibério refletiu sua preferência pelos temas filosóficos e literários em detrimento das performances teatrais ou mesmo esportivas manifestadas em Nero; colateralmente, a mesma preferência contribuíra para alimentar a percepção arrogante perante a população. $O$ envolvimento do Princeps com a cultura grega manifestava-se principalmente no ambiente privado, o que pode ter sido um componente adicional à ideia de um temperamento mais propenso à reclusão e que, livre das atribuições políticas da cidade de Roma, referendava

\footnotetext{
${ }^{652}$ Vida de Tibério, 70.1-3.

${ }^{653}$ Vida de Tibério, 61.
} 
seu interesse refinado por esta cultura e a busca de erudição sobre seus componentes filosóficos e literários ${ }^{654}$.

Um exemplo notável desta influência é observável no conjunto das peregrinações de Tibério, particularmente durante sua estadia na já mencionada villa de Espelunca (Sperlonga). No que diz respeito às esculturas presentes no local, Stewart ${ }^{655}$ afirma que elas representam um indício que afirma a existência de um programa unificado de composições feitas sobre o mesmo mármore e provavelmente pela mesma oficina (talvez da Ásia Menor), pois todo o conjunto apresenta técnicas semelhantes em seus traços. Mais ainda, a instalação no interior da caverna, construída durante o século I d.C. (conquanto a estrutura arquitetônica da villa situada nas proximidades apresente indícios referentes ao final do período republicano) parece ter sido feita logo no começo do governo de Augusto. Igualmente, reformas teriam sido realizadas ou no final do governo deste último, ou já durante o tempo de Tibério, uma vez que a fachada interna da caverna parece ter sido revestida com elementos estéticos típicos deste período: a obra, cuja autoria pertenceu à artesãos gregos de Rodes, possivelmente se relacionou a um conhecimento e interesse prévio do Imperador sobre o trabalho destes artesãos, cuja relação com a região de origem nos leva a crer que as reformas foram iniciativas da mente deste Princeps.

Neste contexto, a temática das esculturas de Sperlonga que envolvem o triclinium (sala de jantar) da caverna pressupõe que seu proprietário detinha um gosto bastante erudito e peculiar por elementos da mitologia grega, e que estavam bastante em voga durante o período Júlio-Claudiano; se relacionarmos a predileção de Tibério pela cultura grega, bem como sua predileção por banquetes relacionada acima, além da evidência do fatídico desmoronamento em 26 d.C. - e que culminou, de acordo com a tradição, no fortalecimento dos laços de confiança entre Sejano e o Princeps - é plausível que todo o conjunto de esculturas ali estabelecidas foi fruto do desejo de Tibério.

Conforme dedutível de outras evidências - como as menções elementos mitológicos e eróticos da cultura helenística presente nos hábitos do Imperador

\footnotetext{
${ }^{654}$ RUTLEDGE, 2008, p. 465-7.

655 1977, p. $76-8$.
} 
em Capri - é possível crer que as várias representações de Odisseu em diferentes momentos da narrativa da Odisséia de Homero também façam menção a uma autorepresentação do Princeps. De maneira similar a Odisseu, Tibério havia passado boa parte de sua vida fora de sua cidade natal, bem como compartilhava de características do herói homérico, como o penetrante intelecto, o zelo excessivo, a aspereza proverbial e o orgulho perante os próprios feitos militares. Embora isto não pareça em última instância algo conclusivo, ajuda-nos a corroborar a empatia e a erudição de Tibério no que dizia respeito a estes componentes da cultura grega ${ }^{656}$.

De modo semelhante à Papírio Paeto (um dos epicuristas amigos de Cícero), que vivera nas imediações de Neápoles - um dos centros intelectuais do epicurismo - e abandonara permanentemente Roma, ou mesmo como Mário, Pompeu e César que, embora não tenham seguido os passos do primeiro, também construíram sua villae em uma posição cimeira que lhes permitiam tudo observar, Tibério imitara estes precedentes. Portanto, em vários aspectos o afastamento do Princeps se assemelhara às visitas feitas por outros aristocratas romanos à região da Campânia durante as duas últimas gerações anteriores.

Este hábito não fora fonte de estranhamento por parte dos autores que escreveram sobre seu governo, mas sim o fato de nunca mais ter regressado para Roma, e principalmente por Tibério ter escolhido a localidade pouco comum de Capri como o ambiente de seu refúgio ${ }^{657}$. O que lá poderia ser tão atrativo para Tibério? Em primeiro lugar, se uma ilha era o mais apropriado refúgio de todos os problemas existentes, Capri estava estabelecida como um espaço geográfico estratégico. Além de bela, os limites de seu acesso permitiam-na que fosse bem vigiada, ao mesmo tempo em que não impedia a construção de suntuosas residências para o Imperador e a corte.

Distante apenas vinte e nove quilômetros de Miseno, base naval imperial na península itálica, tal posição tornava possível ao Princeps solicitar visualmente a aproximação de embarcações para a ilha, cujo trajeto para o continente variava entre quatro e oito horas, de acordo com a força e a direção dos ventos. Igualmente, a distância de Capri para Putéolos, um dos principais

\footnotetext{
${ }^{656}$ STEWART, 1977, p. $83-87$.

${ }^{657}$ HOUSTON, 1985, p. 181-2.
} 
centros de importação de grãos e o principal porto comercial da costa oeste italiana, era de apenas aproximadamente trinta quilômetros. O Princeps contrariamente à ideia de isolamento e abandono - em verdade poderia manter (caso desejasse ou necessitasse) comunicação direta com uma das principais bases militares romanas e com o mais efervescente centro comercial da Itália, bem como fácil e rápido acesso ao continente pela proximidade com Miseno ${ }^{658}$.

A particularidade destes apelos para o Princeps permite-nos pensarmos em aspectos mais amplos. De acordo com John D'Arms ${ }^{659}$ não somente o Imperador, mas uma parte significativa da aristocracia romana entre o final da República e os dois primeiros séculos do Principado sentira-se atraída pela confluência de quatro atrativos na região da Campânia: econômicos, higiênicos, estéticos e, principalmente, por uma considerável influência da cultura helênica que continuara se fazendo presente na região; a tendência para a associação entre riqueza, prestígio com a posse de propriedades na região, o desejo de eventuais fugas do ambiente tumultuado, conflituoso e insalubre da cidade de Roma, e o crescente individualismo e busca por privacidade podem ser observados como elementos que atraíram inúmeros romanos para a região durante um longo período.

Em primeiro lugar, o gosto pelo requinte e a suntuosidade adentraram no mundo romano através do contato e a influência dos grandes centros do oriente grego, em contraste aos hábitos frugais dos antigos romanos. Em segundo, embora houvesse uma tendência à crítica dos costumes gregos como uma representação coletiva da mollitiae (frouxidão) e do otium (no sentido de inércia e inação), características do temperamento helênico, a emulação destes aspectos culturais pela aristocracia senatorial romana logo se tornaram por demais sedutores para serem renunciados; já durante o período dos Cipiões negotium (afazeres públicos) e officium (no sentido de dever, obrigação) eram contrastados com o desejo de lazer e relaxamento, e não havia incongruências entre a manutenção dos afazeres públicos e os intervalos para o descanso: se havia uma região particularmente atrativa para o cultivo deste estilo de vida, o local mais cobiçado era a costa da Campânia. Em terceiro lugar, gramáticos, tutores, literatos e filósofos gregos desde tempos

\footnotetext{
658 BOWERSOCK, 1965, p. 75; HOUSTON, 1985, p. 182.

659 1970, p. 165.
} 
anteriores eram personagens frequentes do cotidiano das villae e das municipalidades nesta região, tendo permanecido até o período imperial. Refinamento, lazer e erudição interligaram-se e floresceram nos arredores da baía de Neápoles e no restante desta parte da costa italiana ${ }^{660}$.

Igualmente importante, embora muitos romanos tenham apreciado ao longo de sucessivas gerações esta faceta da cultura helênica, relativamente poucos aristocratas optaram por permanecer por boa parte ou pelo restante da vida fora de Roma; o refinamento dos hábitos estrangeiros era apreciado individualmente em suas villae. Como na corte de Tibério em Capri - estas habitualmente contavam com obras de arte, bibliotecas, amplos salões para debates e exercícios literários, pórticos, amplos jardins e outras acomodações que em vários aspectos recapturavam a atmosfera cultural de Atenas.

A despeito do fato de a villa ter sido uma invenção tipicamente romana e ter sido um elemento extremamente representativo no âmbito sociocultural desta civilização, a mesma fora ambiente da transposição de vários aspectos da tradição grega, e que tiveram seu vigor renovados em solo romano: a fusão de características da cultura grega e romana encontrara condições particularmente propícias tanto em Neápoles, quanto nos seus arredores e demais adjacências da região da costa da Campânia. Neste local, as instituições helênicas continuaram a permear as estruturas municipais romanas e a encorajar seus cidadãos a absorver a cultura grega ou mesmo adotar hábitos dos gregos ${ }^{661}$.

O distanciamento físico da cidade de Roma e o interesse do Princeps em selecionar suas companhias em seu afastamento, a vida social e os compromissos políticos oriundos de suas relações com outros cidadãos não cessaram completamente. Já observamos que Tibério não deixara de retornar para o continente; suas viagens pela costa italiana e seu território adentro supuseram contatos com outros aristocratas ou mesmo membros da família imperial. Igualmente, alguns destes últimos frequentaram sua corte em Capri: entre 27 e 30 d.C. é provável que Druso (filho de Agripina) acompanhado de sua esposa Emília Lépida possam ter permanecido algum tempo na ilha, uma

\footnotetext{
${ }^{660}$ D'ARMS, 1970, p. 166.

${ }^{661}$ Idem, p. 167.
} 
vez que ele será reconduzido aprisionado de algum lugar não especificado para Roma em 30 d.C..

Neste mesmo ano Gaio César também será enviado para Capri, onde provavelmente permanecera o restante de todo o governo de Tibério, possivelmente acompanhado de sua esposa Júnia Claudila a partir de 33 d.C., pelo menos até sua morte em decorrência do parto tempos antes do falecimento do Princeps. Por último, provavelmente Tibério Gemelo também pode ter permanecido durante algum tempo em Capri, uma vez que ele é mencionado dentro do mesmo contexto de Gaio César, no período próximo de sua ascensão. Antônia, historicamente relacionada à descoberta da eventual conspiração de Sejano, possuía uma villa em Miseno o que nos ajuda a pressupor a possibilidade de que ela possa ter visitado Tibério em Capri ${ }^{662}$.

Além de membros da família imperial, outras companhias teriam frequentado a corte. O futuro Imperador Vitélio provavelmente estivera presente $^{663}$, e também Galba, que possivelmente lá recebera a previsão de Tibério de que um dia também se tornaria um Princeps ${ }^{664}$. De modo semelhante, Herodes Agripa, rei da Judéia, teria se encontrado com Tibério em Capri; Asínio Galo receberá ordem de Prisão após a celebração de um banquete na ilha, e dois antigos amigos do Princeps que estiveram com ele em Rodes, Vesculário Flaco e Júlio Marino, foram condenados à morte após serem julgados em Capri pelo envolvimento com a conspiração de Sejano. Sexto Vestílio, ex-pretor, cometera suicídio quando tivera sua permissão de acesso negada por Tibério ${ }^{665}$, o que pressupõe que em algum momento ele possa ter visitado o Princeps em sua corte fora de Roma; este fato é um exemplo da possibilidade de que uma aproximação com o Imperador era possível, e a despeito das limitações de acesso, podemos pressupor uma movimentação de aristocratas e outros associados de Tibério e da família imperial entre Roma e Capri666.

Para além das companhias que iam e vinham da corte em Capri, é possível que tenha havido outras que lá permaneceram de modo mais ou

\footnotetext{
${ }^{662}$ Plínio O Velho, História Natural, 9.172. Cf. HOUSTON, 1985, p. 184.

${ }^{663}$ Suetônio, Vida de Vitélio, 3.2. Cf. HOSTON, 1985, p. 184.

${ }^{664}$ Tácito, Anais, 6.20.

${ }^{665}$ Idem, 6.9.

${ }^{666}$ HOUSTON, 1985, p. 184-5.
} 
menos permanente. O senador Coceio Nerva teria sido o único membro desta ordem social que permanecera praticamente todos os seus últimos anos com Tibério; Nerva, além de versado em direito, teria sido responsável pelo abastecimento de água em Roma entre 24 e 33 d.C., ano de sua morte ${ }^{667}$.

Além de Cúrtio Ático, que morrera como uma das vítimas das intenções de Sejano ${ }^{668}$ o restante da comitiva era de estudiosos gregos. Sejano e Macro, embora fossem presenças constantes, também vinham e voltavam para Roma, assim como é possível que Ênia, esposa deste último tenha estado em companhia de Gaio César e, consequentemente de Tibério em algum momento entre 36 e 37 d.C. Entre os gregos, dois podem ser identificados: o primeiro foi Trasílo, astrólogo e astrônomo alexandrino e companhia do Princeps desde seu exílio em Rodes, casado com Aka, princesa da Comagênia, cujo filho era um membro da corte imperial no período anterior à ascensão de $\mathrm{Nero}^{669} \mathrm{e}$ morrera em 36 d.C., pouco menos de um ano antes de Tibério ${ }^{670}$.

O segundo é Cáricles, médico e conselheiro pessoal do Princeps, embora só possamos confirmar sua presença de fato nos últimos dias anteriores à morte deste último. Outro associado de origem grega pode ter sido Tibério Júlio Papo, responsável pelas bibliotecas imperiais em Roma durante os governos de Tibério, Gaio César e Cláudio, cuja designação comes (associado) encontrada em uma inscrição evidencia a possibilidade de que este tenha sido não apenas um mero funcionário, mas um conselheiro pessoal do Princeps, conforme fora Trasílo ou Cáricles ${ }^{671}$.

Nesse sentido, é provável que a residência imperial de Tibério em Capri tenha contado, dadas as proporções, com um aparato de corte não menos significativo do que a existente em seu palácio na cidade de Roma. A escassez de evidências na documentação não nos permite extravasar certos limites, mas é plausível que as dependências imperiais na ilha tenham contado com um corpo de funcionários, companhias pessoais do Princeps e dos membros da família imperial lá presentes, bem como libertos, escravos, e evidentemente soldados. Em um primeiro momento, as motivações de Tibério para ter se

\footnotetext{
${ }^{667}$ Frontino, de aq. 102. Cf. HOUSTON, 1985, p. 186.

${ }^{668}$ Tácito, Anais, 6.10.

669 Idem, 6.22.

670 Dion Cássio, 58.27; Suetônio, Vida de Tibério, 62.

${ }^{671}$ L'Anee Epigraphique, 1960. 26 apud HOUSTON, 1985, p. 186-7.
} 
afastado de Roma e passado os seus últimos anos na região da Campânia não teriam sido nada estranhas aos olhos da aristocracia italiana ou mesmo entre provinciais, uma vez que o destino escolhido pelo Imperador fora uma preferência de seu antecessor e de inúmeros outros romanos desde o período republicano, que buscavam lá as mesmas distrações aos compromissos públicos da capital.

Entretanto, de modo diferente da maior parte de seus concidadãos, Tibério não retornara para Roma, e este fato contribuiu negativamente para a preservação dos naturais laços de amizade (amicitia) e interação política com muitos dos membros da ordem senatorial e equestre. Embora fosse uma atitude tipicamente romana viajar para a Campânia e desfrutar dos lazeres e do refinamento intelectual de matrizes gregas presentes nessa região, também era presumível que um romano voltasse tempos depois para Roma e para os seus deveres como cidadão.

Em contrapartida, Tibério preferira continuar desfrutando de um estilo de vida nos moldes campanianos e em uma ilha em que ele pudesse controlar diretamente 0 acesso de seus familiares e associados, embora as visitas que fizesse para o continente permitissem-no um contato relativamente satisfatório com seus interlocutores, fosse por meio de visitas ou mediante o envio de correspondências imperiais. O cotidiano de seus últimos anos de vida foi bastante consistente com suas preferências pela cultura grega e bastante similares aos hábitos de inúmeros aristocratas na região; as instituições gregas haviam permanecido na Campânia, e eram apreciadas por notáveis romanos, desde o tempo dos Cipiões, passando por Cícero e Augusto.

Igualmente, Tibério herdara 0 gosto por aspectos das cortes helenísticas, o que se refletiu na disposição urbanística das residências em Capri, nas frequentes companhias compostas por literatos e cientistas de origem grega, bem como pelos exercícios intelectuais que praticava fora de Roma $^{672}$. Contudo, com sua morte em 37 d.C., podemos dizer que encerra-se o período de proeminência de Capri; se esta havia adquirido destaque após sua aquisição por Augusto, que iniciou uma série de obras arquitetônicas que, posteriormente ampliadas por Tibério, fizeram da ilha um novo centro decisório

${ }^{672}$ HOUSTON, 1985, p. 191-2. 
do poder romano, nenhum outro Imperador demonstrará - pelo menos os testemunhos se calam a respeito - o mesmo interesse de antes.

A partir de então, a ilha tornou-se apenas um pequeno elemento dentro do imenso patrimônio dos imperadores e, com a exceção de esparsos resquícios arqueológicos, têm-se um registro eclesiástico de que Capri foi em 523 d.C. doada por certo senador chamado Tertullo para a abadia de Montecassino, ação ratificada pelos imperadores Justiniano e Justino. Verdadeiro ou não, em certa medida o documento sugere que em determinado momento do último período imperial Capri deixou de ser significativo como parte de um patrimônio imperial e tornou-se meramente uma propriedade privada $^{673}$.

${ }^{673}$ Pedro Díacono, Regesto, T. 91 apud SAVINO, 1999, p. 438-9. 


\section{2- A sucessão imperial}

\subsection{1 - O afastamento do Princeps: breve êxito e eliminação de Sejano}

Tibério buscou um refúgio aprazível e distante de Roma como maneira de atenuar as pressões políticas que os primeiros anos de governo the trouxeram, tanto na relação com os membros da família imperial, quanto com seus concidadãos inseridos no cotidiano da capital do Império. O distanciamento não significou isolamento, e os anos posteriores a 27 d.C. demonstrarão que, mesmo fora de Roma, tecnicamente não houve grandes mudanças no conjunto da administração imperial; o cerne do poder decisório residiu onde o Imperador estava.

Com Tibério em Capri, a questão da sucessão imperial passou a se vincular, em um primeiro momento, diretamente à posição de influência de Sejano perante o Princeps. A corte, centro do poder imperial, não se encontrava mais na Cidade de Roma, seu acesso já não era tão facilitado como outrora, e não somente o núcleo familiar de Agripina, mas principalmente membros da aristocracia senatorial e equestre haviam se tornado satélites posicionados em uma distância de acesso e favorecimento quase que exclusivamente controlada pelo Imperador.

Contudo, desde então e mesmo após a eliminação de Sejano em 31 d.C., as interações políticas com o Princeps estiveram sujeitas a intermediação de indivíduos em contato com este último em Capri, fato que possibilitou a ascensão final - efêmera e fulminante - do prefeito da guarda pretoriana. A primeira investida de Sejano foi direcionada contra Nero, o mais velho dos príncipes e neste momento o mais provável candidato à sucessão imperial. Nero teria acompanhado a comitiva imperial na Campânia durante 26 d.C., antes da ida de Tibério para Capri, embora não saibamos se em algum momento o primeiro estivera presente na ilha. Por outro lado, os ataques de Sejano ao príncipe são imediatamente posteriores ao afastamento do Imperador. Tácito afirma ${ }^{674}$ que Sejano valera-se de indivíduos que assumiram

${ }^{674}$ Anais, 4.59.3. 
a função de acusadores e bajuladores de Nero; a proximidade da sucessão teria inflamado sua ambição e abalado sua circunspecção: clientes e libertos teriam confidenciado que, além de preferido pelo povo e o exército, era impenetrável à ação de Sejano, beneficiado pela complacência de um velho Princeps.

Informado deste comportamento, a fiscalização e a manipulação de informações por Sejano logo começara a incomodar Tibério; consequentemente a presença de Nero passou a ser evitada por todos ao mesmo tempo em que era satirizado e criticado ${ }^{675}$. Observemos a rede de intrigas: Tácito afirma ${ }^{676}$ que qualquer ação de Nero parecia incorrer em culpa; toda a rotina do jovem príncipe era relatada por sua esposa, Júlia Livila (filha mais nova de Druso Cláudio) para sua Lívia Júlia, que retransmitia para Lívia, esta para Sejano, que finalmente confidenciava-se com Druso, irmão mais novo de Nero, gradualmente manipulado pela promessa de ascensão mediante a eliminação de seu irmão, preterido por Agripina, e outro alvo de eliminação ${ }^{677}$.

Com Tibério longe de Roma, Sejano parecia livre para atacar a família de Agripina: este último contava deliberadamente com o apoio de seus soldados, que the informavam de toda a rotina em sua residência ${ }^{678}$. Tanto ela quanto Nero foram instigados em sua desconfiança, aconselhados pelos mais próximos a se protegeram entre as legiões próximas à Germânia, ou a abraçarem a estátua de Augusto no Fórum, como maneira de implorar pela ajuda do Senado e do povo; tudo isto era reportado a Tibério como se fossem reais intenções de ambos. Também teria sido neste período que Agripina fora submetida ao cárcere privado em Herculano e arranjos feitos para encarcerar Nero, enquanto Gaio César passara a viver com sua avó Antônia ${ }^{679}$.

Além das investidas contra o núcleo familiar de Agripina, Sejano atuou contra os associados deste último núcleo e mesmo contra seus próprios opositores, condição que viera coligada de uma intensificação na ação dos acusadores. No final de 27 d.C. e durante o início do ano seguinte, o senador

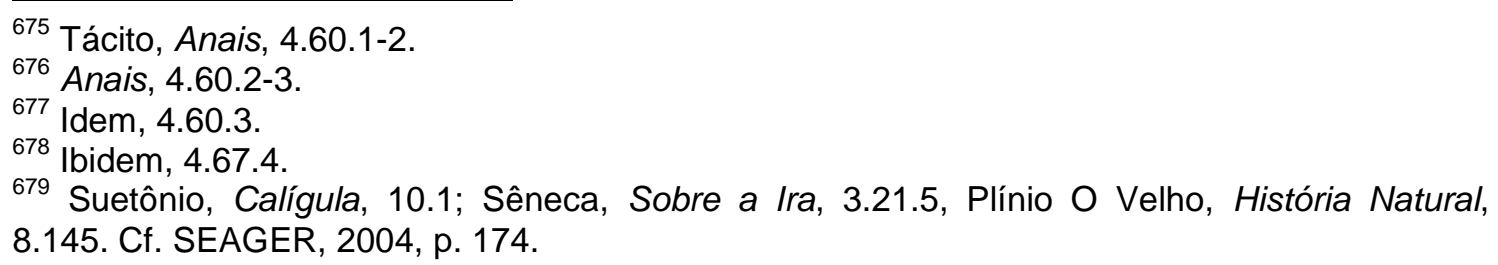


equestre Títio Sabino voltou a ser o centro das atenções de seus detratores: Tácito afirma ${ }^{680}$ que o ano de 28 d.C. começara com seu aprisionamento em virtude de sua relação de amizade com Germânico César; anunciada quatro anos antes, a mesma acusação teria sido agravada pelo fato de que Sabino - o último dos clientes remanescentes - não se constrangera em afirmar publicamente a sua amizade para com Agripina e seus filhos.

A sua conduta teria feito com que Títio Sabino fosse acusado por Latínio Latiário, Pórcio Catão, Petílio Rufo e M. Ópsio, ex-pretores desejosos de ascensão ao consulado, o que só seria possível por influência de Sejano ${ }^{681}$. Consequentemente, Dion Cássio aponta ${ }^{682}$ que Latiário, como favor prestado a este último, colocara seus cúmplices no sótão do apartamento de Sabino e o induzira a falar (como de costume) sobre o que tinha em mente; semelhante estratagema foi amplamente utilizado e evidenciava o desejo dos acusadores em obter alegações ou segredos de uma vítima que pudessem comprometê-la e, havendo um propósito, a mesma liberdade de expressão poderia servir para um acusador delatar os demais, e estes últimos serem punidos por qualquer sentença fora do comum ${ }^{683}$.

No que tange ao episódio, Sabino teria sido vitimado por uma emboscada empreendida pela aproximação arquitetada por Latínio Latiário e acompanhada pelos demais; a confiança do equestre conquistada por este último fizera com que Sabino lamentasse o destino de Agripina, criticasse a ambição e arrogância de Sejano, e por fim atacasse Tibério ${ }^{684}$. Sabino fora então acusado de conspiração contra o Imperador, e durante a cerimônia de ano novo o Princeps salientara que Sabino teria subornado alguns de seus libertos imperiais com esta intenção; antes de morrer Sabino gritara que assim decairiam as vítimas de Sejano ${ }^{685}$.

Após sua execução, Tibério agradecera os senadores pela punição, tendo relatado que sua vida estaria em perigo e que pressentia emboscadas de seus inimigos, segundo Tácito ${ }^{686}$ Agripina e Nero. $O$ afastamento de Tibério

\footnotetext{
${ }^{680}$ Tácito, Anais, 4.68.1.

${ }^{681}$ Anais, 4.68.2.

${ }^{682}$ 58.1.1.

${ }^{683}$ Dion Cássio, 58. 1.1-3.

${ }^{684}$ Tácito, Anais, 4.68.3-4.

${ }^{685}$ Dion Cássio, 58.1.4; Tácito, Anais, 4.70.1.

${ }^{686}$ Anais, 4.70.4.
} 
contribuiu negativamente para sua percepção do ambiente político em Roma: se anteriormente 0 Princeps refutara acusações contra sua pessoa aparentemente implausíveis - uma marca de sua temperança (moderatio) - a partir de seu afastamento para Capri, quase todas as acusações passaram a ser consideradas como latentes ataques à sua pessoa e à sua integridade física.

A condenação de Sabino, além de exemplificar esta condição, figurara como a remoção do último apoio aristocrático ao núcleo familiar de Agripina, completamente enfraquecido e isolado após o afastamento de Tibério ${ }^{687}$. A animosidade entre o Imperador, Agripina e Nero pode ser percebida em Veléio Patérculo ${ }^{688}$ : tendo em vista que a obra provavelmente foi escrita em 30 d.C. (antes da queda de Sejano), este autor lamenta a maneira como os três últimos anos de seu governo haviam afligido cruelmente o Imperador, entristecido e indignado com o sofrimento recebido por meio de sua nora e seu neto.

Contudo, o desconforto político se ampliaria ainda mais. Após o agradecimento do Princeps, o senador Asínio Galo propusera que o Princeps revelasse ao Senado os seus medos e permitisse que estes fossem removidos, algo que para Tácito ${ }^{689}$ implicava no vínculo de Agripina enquanto tia materna de seus filhos. Irritado com a proposição, Tibério teria sido suavizado por Sejano para que não se precipitasse diante da aparente provocação deste senador ${ }^{690}$. Por outro lado, Dion Cássio ${ }^{691}$ afirma que a ocasião servira de pretexto para que Tibério atacasse Asínio Galo - que havia se casado com Vipsânia, sua primeira esposa - e que sempre se expressara de livre opinião sobre os assuntos do Império; tanto a vida de Galo quanto a de Agripina tiveram desfechos parecidos e relacionados, como será visto mais adiante. Antes disso, ainda em 28 d.C., Júlia Augusta faleceu, após vinte anos de exílio na ilha de Trimério, mediante um modesto suporte de Lívia, que também faleceria no ano seguinte ${ }^{692}$.

\footnotetext{
${ }^{687}$ LEVICK, 1999, p. 133; SEAGER, 2005, p. 175.

${ }^{688} 2.130 .4$.

${ }^{689}$ Tácito, Anais, 4.71.2.

${ }^{690}$ Idem, 4.71.3.

${ }^{691}$ 58.3.1.

${ }^{692}$ Tácito, Anais, 4.71.4.
} 
Durante o mesmo ano os Frísios se rebelaram e o Senado implorou pela presença de Tibério e Sejano em Roma ${ }^{693}$. Embora nada seja comentado sobre a revolta, Tácito se utiliza deste evento para demonstrar a continuidade da ascensão de Sejano e o começo da concorrência com o Princeps em relação à legitimidade política. Não obstante os senadores tivessem sido consultados sobre diversos assuntos, ao final estes votaram a construção de dois altares em homenagem à Clementia e à Amicitia (virtudes imperiais bastante valoradas por Augusto, e comumemente utilizadas também por Tibério) com efígies do Princeps e de Sejano em volta destes respectivos monumentos, conquanto - a despeito das súplicas - nem um dos dois tenha se aproximado da Cidade de Roma ou de seus arredores ${ }^{694}$. Ambos se apresentaram às margens da costa da Campânia, o que não impedira que para o local rumassem senadores, equestres, e uma considerável porção da plebe, particularmente ansiosos com relação à Sejano, com o qual encontros eram repletos de entraves e dependente de suas próprias escolhas ${ }^{695}$. E no que dizia respeito ao seu comportamento com associados, senadores e clientes

Era notória sua arrogância na medida em que observava do átrio a atroz servidão destes; dado o tamanho da cidade, em Roma é comum o alvoroço e que a incerteza ocorra nos negócios: lá a quedar-se prostrados no prado ou na costa indistintamente noite e dia, eles suportavam do mesmo modo o favorecimento ou desdém dos porteiros até inclusive isto ser proibido; e um angustiante retorno para a Cidade àqueles os quais não houve conversação nem a dignidade de serem olhados, e aos perniciosamente ávidos de inauspiciosa amizade um pesado desfecho se aproximava ${ }^{696}$.

\footnotetext{
${ }^{693}$ Idem, 4.71.4.

${ }^{694}$ Tácito, Anais, 4.74.2-3.

${ }^{695}$ Idem, 4.74.3.

${ }^{696} \mathrm{Ibidem}, 4.74 .4$. Um relato muito parecido é feito por Dion Cássio, embora associado aos eventos de 31 d.C.. Este autor afirma (Dion Cássio, 58.5.2) que havia grande rivalidade e conflito em relação à presença de Sejano, com os indivíduos temerosos não apenas por não serem vistos pelo seu patrono, mas por medo de que pudessem ser também os últimos a aparecerem perante ele, já que qualquer olhar ou palavra, especialmente os proferidos pelos mais proeminentes homens, eram cuidadosamente observados. Mais ainda, Dion Cássio complementa (58.5.3) que aqueles que naquele momento detinham uma posição de proeminência, enquanto resultado de um prestígio ancestral, não estavam muito inclinados a buscar por sinais de amizade de outros, e se tais manifestações eram requisitadas por partes
} 
Desta maneira, observamos que Sejano havia conseguido estabelecer fortes vínculos entre a aristocracia senatorial e equestre de Roma, enquanto em que Tibério parecia cada vez mais isolado ou sujeito à intermediação de Sejano no trato com seus concidadãos. É provável que esta situação tenha provocado enorme dissabor entre vários membros da aristocracia, uma vez que estes se viam gradualmente mais distantes de uma interlocução com o Princeps, sujeitos às intenções de um cidadão cuja linhagem e posição eram incongruentes ao poder alcançado e demonstrado (e não surpreendentemente ressentido), e que consequentemente se viam dispersos quanto à busca de apoio: estes deveriam manter-se leais ao Princeps? A vinculação com Sejano representava também vinculação ao Princeps? E como ficaria o destino destes se um se voltasse contra o outro, ou mesmo daqueles que ainda esperavam pela ascensão de um sucessor dentro da família imperial? Em um ambiente político em que a patronagem e os vínculos de solidariedade tornaram-se as reais balanças do êxito social, incorrer em tamanho erro poderia ser irreversível.

O relato de Tácito nos aponta que em Roma a incerteza tornava-se crescente na medida em que Sejano parecia cada vez mais proeminente. Em contrapartida, Tibério valera-se da rápida travessia para organizar o matrimônio de Agripina Menor, filha mais velha de Germânico César, com Gneio Domício Aenobarbo, tendo ordenado que o casamento se realizasse na Cidade de Roma; o filho nascido nove anos após o enlace seria o futuro Imperador Nero ${ }^{697}$.

O ano de 29 d.C. iniciou-se com a morte de Lívia Drusila, aos oitenta e seis anos. Tácito afirma ${ }^{698}$ que seu funeral - cujo elogio fora pronunciado por Gaio César - fora bastante modesto, e que seu testamento permanecera por muito tempo sem execução. Sem comparecer a Roma, tendo alegado excesso de responsabilidades pela sua ausência, o Princeps também recusou inúmeras

destes últimos, que estes não taxassem os primeiros por isso, visto que eles sabiam muito bem que esta atitude não representava menosprezo; mas aqueles que em contrapartida apreciavam um fortuito esplendor buscavam avidamente todas as atenções, necessitando demonstrar 0 seu posicionamento de forma ampla, e se porventura estes falhassem em obtê-la sentiam-se aflitos como se estivessem sendo açoitados e irritados como se estivessem sendo insultados.

${ }^{697}$ Tácito, Anais, 4.75.

${ }^{698}$ Anais, 5.1. 
das honras propostas pelo Senado, especialmente sua deificação; desde seu afastamento, Tibério teria falado com Lívia apenas uma única vez ${ }^{699}$. Tácito também afirma ${ }^{700}$ que a morte de Lívia rompera a última barreira política para a dominação (dominatio); ainda em vida, Tibério teria sido mais complacente e Sejano não se atrevera a contrariar sua autoridade, o que justificara o envio imediato de uma correspondência com acusações a Agripina e Nero, fato até então impedido por vontade de Lívia.

De acordo com Robin Seager ${ }^{701}$, embora a cronologia dos fatos dada por Tácito pareça lógica, não se pode dizer o mesmo de seu argumento: não há evidência alguma de que em algum momento do governo de Tibério sua mãe tivesse intercedido em favor de Agripina; pelo contrário, Tácito aponta em várias passagens indícios de animosidade entre $a b^{702}$, e não há nada que afiance a iniciativa de Lívia em ter adiado o envio da correspondência contra sua nora e seu neto antes de sua morte.

De qualquer maneira, a correspondência chegou ao Senado. Tácito afirma ${ }^{703}$ que Nero recebera somente acusações de relações homoeróticas e imoralidade, enquanto que Agripina fora censurada em sua arrogância e seu temperamento truculento - em meio a um Senado silencioso e alarmado. Nesse ínterim, o consular Cota Messalino (cônsul em 20 d.C.) propusera medidas severas, conquanto entre outros tenha havido apenas agitação. Júnio Rústico, escolhido pelo Princeps para compilar os registros senatoriais, teria antevisto a possibilidade de perturbações políticas e alertara os senadores para que não promulgassem qualquer moção contra Agripina e Nero, pois o Imperador poderia arrepender-se disto no futuro; simultaneamente a população do lado de fora do Senado, portando efígies de ambos os primeiros, teria irrompido em protestos alegando que a correspondência era forjada e que Tibério não desejava que o extermínio mirasse sua própria família; panfletos contra Sejano teriam circulado com pretensas assinaturas de consulares, um

\footnotetext{
${ }^{699}$ Suetônio, Vida de Tibério, 51.

${ }^{700}$ Anais, 5.3.1-2.

${ }^{701} 2005$, p. 176.

702 Cf. Tácito, Anais, 1.33, 2.43, 4.12.

${ }^{703}$ Idem, 5.2-3.
} 
pretexto para dar vazão ao sentimento de desaprovação pelo prefeito da guarda ${ }^{704}$.

O encadeamento dos fatos neste episódio pode ser considerado uma reação recorrente: conforme ocorrera anos antes com Júlia Augusta, Júlia Menor e Agripa Póstumo, transgressões morais adquiriram gravidade política, e uma vez sem condicionantes legais, Tibério teria seguido o paradigma de Augusto para a repressão de possíveis ameaças políticas oriundas do seio da própria família imperial. Este pretexto novamente funcionou como uma maneira de desviar a questão em foco (a transmissão dos poderes imperiais), e torná-la um assunto alheio ao Senado e ao povo, além de uma questão de fórum privado (a responsabilidade do pater familias). Contudo, isto não contivera a reação popular, operada pelos apoiadores de Agripina mediante os mesmos paradigmas observados quando a disputa pelo acesso ao poder concentrou-se na iniciativa de seus outros familiares ${ }^{705}$.

Entretanto, não podemos afirmar que as investidas contra Agripina e Nero originaram-se exclusivamente de Tibério: se em parte houve certo benefício decorrente de manter-se distante da agitação que estas ações provocaram no Senado e entre a população, em contrapartida o mesmo distanciamento lhe impediu novamente de analisar a reação da plebe como reflexo da crescente animosidade diante da perseguição a alguns dos membros da família imperial. E sob este aspecto, Sejano beneficiara-se uma vez mais do isolamento de seus remanescentes em Roma, e da aparente sensação de confusão e impotência de boa parcela do Senado. Desse modo, Tácito complementa ${ }^{706}$ ainda que em relação à Sejano, este fato tornara

mais violenta a sua ira e a as alegações a serem [contra o Senado] imputadas: que a dor do Princeps estava sendo desprezada pelo Senado, que o povo havia desertado; extraordinárias assembleias já eram organizadas e decisões senatoriais eram lidas: 0 que restaria senão que se desembainhassem as espadas e, escolhessem como líderes e

\footnotetext{
704 Ibidem, 5.4.1-3.

705 LEVICK, 1999, p. 133-4.

706 Anais, 5.4.4.
} 
Imperadores aqueles cujas efígies estivessem sendo seguidas ao invés de estandartes?

Consequentemente, Tácito afirma ${ }^{707}$ que em reação a estes protestos de Sejano, Tibério teria reclamado aos senadores que, em razão de uma farsa promovida por um único senador, sua majestade imperial (imperatoria maiestas) havia sido lograda publicamente. Conquanto de sua parte o Princeps não tenha proposto nenhuma resolução diante destas afirmações, bem como nenhuma atitude foi levada a cabo pelos senadores, todavia Dion Cássio afirma ${ }^{708}$ que em 29 d.C. o poder de Sejano crescera em proporções ainda mais elevadas: o Senado votara a saudação pública de seu aniversário, várias estátuas, votos, libações e juramentos pelo destino de ambos, manifestações que contaram com o apoio dos senadores, equestres, e da população.

De modo que os capítulos referentes ao fim da narrativa consular dos anos de 29, 30 e boa parte do ano de 31 d.C foram perdidos dentro do conjunto dos manuscritos encontrados dos Anais de Tácito, os mais importantes detalhes da ascensão de Sejano e o comportamento da aristocracia e do Princeps em relação a este momento estão presentes em Dion Cássio. Somente mediante elementos esparsos é possível reconstruir o desfecho dos procedimentos senatoriais contra Nero e Agripina. Provavelmente, a réplica enviada por Tibério ao Senado fora suficiente para que este simplesmente aprovasse a decisão que melhor evitasse um novo desagravo perante 0 Princeps: Agripina foi exilada para a ilha de Pandatéria, Nero para a ilha de Pontia, e ambos removidos da corte imperial mediante forte escolta ${ }^{709}$. Em contrapartida, Agripina Menor não sofrera qualquer perseguição; Druso, ainda seria questor neste ano, mas no ano seguinte também seria alvo de Sejano.

A escalada de Sejano contara ainda com o isolamento de Asínio Galo, um dos principais eventos de 30 d.C.. Após a eliminação de Títio Sabino dois anos antes, Dion Cássio afirma ${ }^{710}$ que Galo estaria fazendo corte à Sejano, fosse porque acreditasse que este último poderia tornar-se Imperador, por medo de Tibério, ou talvez como um artifício para tornar Sejano desagradável

\footnotetext{
${ }^{707}$ Idem, 5.5.5.

708 58.2.7-8.

${ }^{709}$ Respectivamente: Suetônio, Vida de Tibério, 53.2, 54.2, 64.

${ }^{710} 58.3 .1-2$.
} 
ao Princeps e promover a ruína deste último. Embora não saibamos como evoluíra esta relação, em 30 d.C., durante as homenagens feitas à Sejano e a Tibério, Asínio Galo teria proposto ao Senado a maior e mais importante partes das honras votadas ao primeiro, e empenhou-se em ser um dos enviados encarregados da concessão destas honras ${ }^{711}$.

De sua parte, o Princeps enviara uma mensagem ao Senado tendo afirmado que Galo era invejoso de sua amizade com Sejano. Contudo, Tibério continuou a tratá-lo de maneira respeitável e amistosa, não obstante o senador tenha sido surpreendido imediatamente após brindar à amizade junto ao Princeps em Capri; Galo foi conduzido ao Senado acompanhado de um pretor destacado para aprisioná-lo e conduzi-lo para a execução ${ }^{712}$. Dion Cássio destaca ${ }^{713}$ que Tibério, após ter agido de tal modo, não teria permitido que sua vítima morresse, mas instruído ao Senado que o senador fosse mantido como prisioneiro dentro da Cidade de Roma, sem direitos civis e sob a vigia dos cônsules ano após ano - com a exceção do consulado exercido por Tibério em que Asínio fora vigiado pelos pretores - para que não se matasse, e para que fosse mantido vivo e em boas condições o quanto fosse possível.

A relação pouco amistosa entre Asínio Galo e Tibério é perceptível desde o início do governo de Tibério, e é bastante explorada por Tácito. De acordo David Shotter ${ }^{714}$ o senador morrera com o peso da desconfiança do Princeps em relação aos seus interesses para com Agripina: Asínio Salonino, filho do senador, foi prometido para uma filha de Germânico ${ }^{715}$. Galo também pode ser considerado como um senador que visara alcançar uma posição de dominância no Senado, algo possível justamente pelo esforço de Tibério em reafirmar a autonomia deliberativa desta instituição. Todavia, a pretensa relação com Agripina e Sejano culminara em um prejuízo evidentemente anunciado para este senador. Além disso, observamos a intenção de Dion Cássio $^{716}$ em valer-se de sua morte como exemplificação de um modus operandi empregado para a proscrição de senadores e equestres em meio a este ambiente de disputas por influência política; tal fato ocorrera com o

\footnotetext{
${ }^{711}$ 58.3.2.

712 Dion Cássio, 58.3.3.

713 58.3-5.

714 1971, p. 456-7.

${ }^{715}$ Tácito, Anais, 3.75.1.

${ }^{716}$ 58.3.6.
} 
mencionado Siríaco, que embora não tivesse cometido nenhum crime ou sido imputado com alguma acusação, teria sido eliminado pelo fato de Tibério ter declarado que ele era um amigo de Asínio Galo ${ }^{717}$.

$\mathrm{O}$ ano de 30 d.C. também representou a última investida bem-sucedida de Sejano contra a prole de Agripina. Dion Cássio afirma ${ }^{718}$ que Sejano forjara acusações contra Druso por meio de Júlia Lívia, esposa do príncipe. Embora Dion Cássio complemente de forma desconexa que Tibério havia enviado Druso para Roma (teria Druso permanecido em Capri, ou estava em alguma espécie de exílio?), Sejano, temendo que o Princeps mudasse de ideia, persuadiu Cássio (provavelmente Cássio Longino, cônsul ordinarius desse ano) a conduzir uma moção contra o príncipe; como Nero, Druso também foi declarado um inimigo público, mas ao invés de ter sido exilado em uma ilha, fora aprisionado em uma masmorra dentro do próprio palácio em Roma ${ }^{719}$.

Após o aprisionamento de Druso, somente dois remanescentes homens da linhagem Júlio-Claudiana ainda permaneceram livres: Tibério Gemelo e Gaio César, respectivamente com dez e dezoito anos (não obstante o último não tivesse tido ainda qualquer experiência política). Embora Cláudio também estivesse livre e tivesse recebido os ornamentos consulares, ele não fora contabilizado nos relatos deste período, uma vez que Tibério recusara a permitir-Ihe sua admissão ao Senado ${ }^{720}$. Aparentemente livre de obstáculos, Sejano parecia ter encontrado aquilo que seria o último degrau para algum tipo de ascensão maior: o núcleo familiar de Agripina estava aparentemente desmantelado, sem apoiadores; Tibério permanecia em Capri, e seu retorno para Roma apresentava-se como algo cada vez mais improvável, condição que certamente trazia incertezas para aqueles que ainda não haviam aceitado a ideia de uma vinculação política a Sejano e seus associados, ou que eram opositores contidos ou declarados do prefeito do pretório.

Todavia, ainda era necessário que alguns passos fossem dados para que Sejano adquirisse maior legitimidade política, e isto envolvia a aquisição de prestígio entre o Senado e uma maior popularidade perante a plebe, a nosso ver já adaptada a ideia de consenso vinculada à soberania da família imperial e

\footnotetext{
${ }_{717}^{717}$ Dion Cássio, 58.3.7.

718 58.3.8.

719 Dion Cássio, 58.3.8-9; Suetônio, Vida de Tibério, 54.2; Tácito, Anais, 6.23.

720 Suetônio, Vida do Divino Cláudio, 5.6.2; SEAGER, 2005, p. 179; LEVICK, 1999, p. 133-4.
} 
à transmissão do poder entre os seus descendentes. Dion Cássio sentencia ${ }^{721}$ que Tibério, após exaltar Sejano e fazer dele um membro de sua família por finalmente - afiança-lo a Lívia Júlia, posteriormente o matou.

A antecipação deste autor sintetiza a ideia de que teria havido uma conspiração e que sua descoberta culminara com a eliminação de Sejano e justificara a posterior expurgação de todos os aristocratas que se vincularam a ele. Discutiremos a plausibilidade desta afirmação abaixo. A retomada da narrativa em Tácito ${ }^{722}$, conquanto fragmentada, também nos permite supor que em algum momento do ano de 30 d.C., além de ter se tornado consorte do Princeps, Sejano obtivera a mão de Lívia Júlia ou mesmo se casara com ela; já Suetônio afirma ${ }^{723}$ que a vinculação à família imperial e a concessão do poder tribunício fora uma armadilha de Tibério.

Não obstante a dificuldade de concatenar estas informações para o preenchimento desta lacuna histórica em um momento tão importante, em verdade provavelmente parte da opinião pública considerava seriamente que em breve Sejano ascenderia a uma posição de poder sem precedentes. Dion Cássio afirma ${ }^{724}$ que Sejano estava tornando-se cada vez mais poderoso e influente, de modo que os senadores e o restante da população encaravam-no como se este de fato fosse o Imperador e mantinham Tibério em uma posição secundária.

Contudo, uma vez que o Princeps soubera desta condição, este não teria nem tratado abertamente esta questão e tampouco a desconsiderado, pois temia que o Senado pudesse prontamente declarar Sejano um Imperador: este último teria cooptado a guarda pretoriana por completo e conquistado apoio dos senadores, em parte pelos benefícios por ele mesmo conferido, em parte pelas esperanças que sua pessoa inspirava, em parte pelo meio da intimidação, feito com que todos os associados de Tibério se tornassem seus amigos, e que the reportassem tudo o que Tibério falava ou fazia, embora nenhum deles informasse a Tibério quais eram as ações de Sejano ${ }^{725}$.

\footnotetext{
${ }^{721}$ 58.3.9.

${ }^{722}$ Anais, 5.6.2.

${ }^{723}$ Vida de Tibério, 65.1.

724 58.4.1.

725 Dion Cássio, 58.4.2.
} 
Porquanto Dion Cássio parta do pressuposto de que o Princeps sabia das intenções de Sejano, este autor aponta (58.4.3) que Tibério não se abstivera de apontá-lo como cônsul, tendo repetidamente usado a expressão "Meu Sejano" em correspondências para o Senado. Nesse ínterim, ao iniciar sua exposição sobre os eventos consulares do ano de 31 d.C., Dion Cássio afirma $^{726}$ que os senadores acreditaram na sinceridade do Princeps e dedicaram estátuas de bronze a ambos em uma variedade de lugares, lavrado seus nomes conjuntamente nos registros públicos, sacrifícios para suas efígies, bem como colocado cadeiras douradas no teatro para ambos. Por fim, 0 Senado teria votado que Tibério e Sejano deveriam ser eleitos como cônsules em conjunto a cada cinco anos e que um corpo de cidadãos deveria recepcioná-los sempre que entrassem em Roma.

Toda a promoção de Sejano, e a demonstração de força perante a aristocracia e a plebe urbana de Roma teriam sido utilizadas como formas de conversão de sua modesta origem em vantagem, ampliar sua popularidade, e enfatizar um precedente que justificasse sua ambição, a despeito da aparente incongruência de sua pretensão, algo justificado no texto de Veléio Patérculo. A relação que este autor encetou ${ }^{727}$ entre Sejano, seus préstimos ao Imperador, e os precedentes políticos de M. Agripa e Augusto podem ser considerados como uma evidência do argumento político que circulara entre segmentos da opinião pública em Roma durante este período. Conquanto sua origem fosse inequivocamente um obstáculo para sua legitimidade perante a aristocracia, o precedente de popularidade de Agripa entre a população poderia compor um vínculo político, a despeito da ausência de vínculos consanguíneos com a linhagem Júlio-Claudiana.

Mais ainda, o casamento com Lívia Júlia poderia romper esta última barreira - embora Tibério tivesse apresentado os empecilhos desta possibilidade anos antes -, o que faria do apoio popular algo ainda mais importante: se desde o início do governo as eleições estiveram concentradas nas mãos dos senadores e realizadas no Campo de Marte, o ano de 31 d.C. contou com a peculiaridade da celebração da eleição consular no Aventino, que fora durante o passado republicano um símbolo da representatividade

\footnotetext{
${ }^{726} 58.4 .4$.

727 2.127.1-3.
} 
popular de sua assembleia. As implicações deste fato tem sido foco de estudos, e uma evidência epigráfica ${ }^{728}$ encontrada no local e creditada à ordem de Tibério nos permite interpretar o que teria sido uma busca pelo arrefecimento dos ânimos da plebe após a eliminação de Sejano ${ }^{729}$ :

Mas agora, uma vez que a incitação [solicitação] criminosa de Sejano destruiu a paz de dezesseis anos, e que uma irregular assembleia eleitoral teve lugar no Aventino onde Sejano foi eleito cônsul e eu, um frágil acompanhante de uma inservível equipe, fui compelido a tornar-me um suplicante, eu peço a vocês com toda a minha força, meus estimados colegas tribais, se eu sempre Ihes pareci um digno e prestativo membro de nossa tribo, se eu nunca abandonei meu trabalho nem...

De acordo com a tradução e interpretação desta evidência feita por Ronald Syme ${ }^{730}$, é provável que Sejano tenha buscado a empatia da plebe mediante associações religiosas com a deusa Fortuna (Fors Fortuna) - uma das mais tradicionais divindades cultuadas por este segmento social -, tacitamente contrapondo-se à também tradicional impopularidade que a família Cláudia detinha pelo seu desprezo pela plebe em Roma. O monte Aventino tivera fortes associações com o passado político deste grupo social: o local teria sido o marco simbólico do fim da opressão patrícia durante o início da República, local de consolidação do culto popular a Diana, Liber e Ceres, bem como fora o local onde Gaio Graco buscara o último refúgio antes de ser assassinado em 121 a.C..

Igualmente, o apoio da plebe teria sido também uma maneira de minimizar a origem italiana (e não Sabina) de Sejano, e a promoção de homens novos uma forma de sugerir à população a possibilidade de expansão dos vínculos de clientela, remetendo a imagem de Sejano à de outro ilustre tribuno da plebe, como Tibério ou Gaio Graco ${ }^{731}$. Contudo, logo se evidenciaria (com a fúria popular após o aprisionamento de Sejano) que o suporte da população

728 ILS, 6044 = EJ 53. Cf. sua interpretação em SYME, 1956, p. 257-266.

${ }^{729}$ Cf. LEVICK, 1999, p. 92, embora a pesquisadora admita que a validade do argumento não transcenda o campo da suposição.

7301965, p. 265.

${ }^{731}$ LEVICK, 1999, p. 135; SEAGER, 2005, p. 180. 
não teria o magnetismo e devoção comparáveis às demonstrações em favor da família de Germânico César, ou mesmo do futuro Imperador Gaio César. Por outro lado, as evidências acima analisadas nos ajudam a considerar que Sejano, assim como qualquer outro aristocrata romano, buscou fortalecer suas associações com outros pares deste segmento social. Isto se refletirá crucialmente abaixo, com a sessão senatorial que desmantelará o sonho do poder tribunício e porá fim à carreira de Sejano.

Nesse ínterim, em 31 d.C., durante a ascensão de Tibério e Sejano ao consulado, Dion Cássio afirma ${ }^{732}$ que os senadores juraram o pacto de fidelidade à Fortuna de Sejano e reiteraram sua denominação como colega do Princeps. Em contrapartida, a partir deste momento Tibério não estivera mais alheio ao que em teoria constituíra os interesses de Sejano, e consequentemente buscara uma maneira de eliminá-lo; diante deste propósito, o Princeps teria iniciado o envio de correspondências variadas tanto a Sejano quanto ao Senado, ressaltando ora seu frágil estado de saúde, ora que estava em perfeitas condições físicas e prestes a retornar imediatamente para a Cidade de Roma.

De acordo com John Nichols ${ }^{733}$, não há qualquer evidência que comprove o argumento de que Tibério teria tomado conhecimento dos desígnios de Sejano mediante uma correspondência enviada por Antônia ${ }^{734}$, embora em Suetônio ou Tácito estejam presentes referências quanto à sua autoria $^{735}$. Nesse sentido, as fontes que enfatizam a importância de Antônia para a eliminação de Sejano provavelmente se basearam em atribuições feitas durante o restante do período Júlio-Claudiano e durante a dinastia dos Flávios: em consideração à existência de uma conspiração política organizada contra Tibério, as referências são concernentes a uma afirmação do historiador Flávio Josefo $^{736}$, cuja constatação para Nicols ${ }^{737}$ teria refletido o estatuto "semioficial" de sua história mediante os eventuais usos que este autor teria feito da

\footnotetext{
${ }^{732}$ 58.6.2-3.

${ }^{733} 1975$, p. $57-8$

${ }^{734}$ Antônia Menor (36 a.C.-38 d.C.), irmã mais nova de Augusto, casada com Druso Cláudio Nero (irmão de Tibério). Seus três filhos remanescentes foram Germânico César, Lívia Menor (viúva de Druso Cláudio e considerada como amante de Sejano) e Cláudio Druso, futuro Imperador.

${ }_{735}$ Vida de Tibério, 61; Anais, 6.3.

${ }^{736}$ Antiguidades Judaicas, 18.181.

${ }^{737} 1975$, p. 58.
} 
documentação e da historiografia disponíveis durante o seu período, em que a tradição teria eventualmente associado a ameaça da influência de Sejano com um fato vinculado menos ao então futuro Imperador Gaio César do que à Tibério.

De todo modo, duas outras perguntas tornam-se necessárias: por que o Princeps subitamente eliminara aquele cuja ascensão fora de sua responsabilidade e cuja confiança the parecia inabalável? Houve uma conspiração promovida por Sejano? E se sim, qual teria sido seu objetivo: suas ambições teriam ultrapassado sua resignação, houve uma reação diante da descoberta de que já não era mais útil ao Princeps, ou tudo não passara de uma ilusão da mente de Tibério?

Até então, a situação política para os eventuais oponentes de Sejano parecia perdida, pois o Princeps parecia completamente comprometido com a colaboração do primeiro, agora cônsul, e provavelmente futuro colega de poder, e Sejano não estava sozinho, conquanto seu apoio estivesse fundamentalmente vinculado à posição alçada pelo próprio Princeps. Por outro lado, a ascensão de Sejano caminhou ao lado da frustração de Tibério em assegurar sozinho e dentro de sua residência imperial a estratégia sucessória engendrada por Augusto; conquanto o passado da linhagem Cláudia fosse favorável aos homens novos, havia limites nesse prospecto e em 31 d.C. a situação da família imperial encontrava-se inevitavelmente vulnerável.

Mais ainda, o precedente de Agripa como colega de Augusto não necessariamente significava que esta era a situação mais desejável por Tibério. Mais importante: a eliminação sistemática dos príncipes em linha sucessória permitiu que um deles, Gaio César (é interessante nos questionarmos se este último teria alguma chance de se tornar Princeps caso seus irmãos não tivessem morrido), favorecido pela linhagem e, a despeito da velhice de Tibério - agora septuagenário - passasse a ter chances de ser o sucessor do Império ${ }^{738}$.

Suetônio afirma ${ }^{739}$ que o Princeps justificara em sua autobiografia que a eliminação de Sejano decorreu da descoberta de uma conspiração contra a vida dos filhos de Germânico César, embora este autor desminta a versão

\footnotetext{
${ }^{738}$ LEVICK, 1999, p. 136; SEAGER, 2005, p. 180.

${ }^{739}$ Vida de Tibério, 61.1.
} 
oficial ao alegar que Nero fora assassinado quando Tibério já sabia das intenções de Sejano e Druso após a morte do prefeito da guarda; em 31 de Agosto de 30 d.C., tendo permanecido até então na residência de Antônia, Gaio César teria sido levado para Capri, onde desde então passara a viver na residência de Tibério ${ }^{740}$. Por outro lado, uma evidencia epigráfica aponta que foi publicamente divulgado que houve uma tentativa de assassinato de Tibério e Gaio César ${ }^{741}$.

De acordo com Barbara Levick ${ }^{742}$ a contumaz hostilidade de Sejano, manifestada em atos e palavras, não fora obliterada após sua morte; ataques contra a integridade dos familiares do Princeps também poderiam ser considerados como ataques ao mesmo, e isto se evidenciara na correspondência lida no Senado de que ele não mais podia confiar na guarda e que estava em perigo; provavelmente Gaio César sabia que, caso Sejano triunfasse sua vida correria perigo, não obstante sua mãe e seus irmãos já estivessem praticamente eliminados da vida pública, o que pode ter justificado sua ida - de bom grado - para Capri ${ }^{73}$.

A despeito da lacuna em Tácito, a continuidade da narrativa no livro VI aponta para esta possibilidade, pois o autor afirma ${ }^{744}$ que Albucila, denunciada em 37 d.C. por profanar a majestade do Princeps, era esposa de Sátrio Segundo, cliente de Sejano e seu informante durante a conspiração, e logo após sua morte, no ano de 32 d.C., P. Vitélio também fora acusado pelo mesmo crime, tendo oferecido suporte financeiro para a conspiração valendose do erário militar, do qual era prefeito.

Assim, embora não concordemos com parte do argumento de Marsh ${ }^{745}$ que acredita que Tibério pretendia avançar Sejano como seu natural sucessor, o autor oferece uma boa alternativa para tentarmos compreender sinteticamente esta questão. Em primeiro lugar, faltou um motivo pertinente para justificar a razão de uma conspiração contra o próprio Imperador; teria sido mais fácil que Sejano esperasse uma promoção do Princeps, e esse último não teria sido imprevidente a ponto de desconsiderar a crise de

\footnotetext{
${ }^{740}$ Suetônio, Vida de Calígula, 10.2.

${ }^{741}$ ILS 157, 158, $159=$ EJ 51, 52, 85.

7421999 , p. 137.

${ }_{743}^{743}$ Suetônio, Vida de Tibério, 65.

744 Anais, 6.47.2.

745 1931, p. 308-9.
} 
legitimidade e provável anarquia militar caso impusesse uma revolução com o assassinato de Tibério. Em segundo lugar, o que provavelmente foi descoberto teria sido a intenção de Sejano de excluir o núcleo de Agripina da linha sucessória, o que de fato é pertinente. Em terceiro, mesmo com a chegada de informações sobre essas eventuais intenções de Sejano a Tibério, a enumeração de apoiadores que foram posteriormente implicados a causas revolucionárias e, portanto eliminados, as evidencias não são suficientes para definir que havia uma conspiração arquitetada e um grupo previamente definido e organizado pronto para derrubar o Princeps e/ou Agripina e seus filhos.

De todo modo, a situação política de Sejano começara a mudar pouco tempo após ter assumido o consulado, e provavelmente o Princeps de alguma maneira percebera ou fora alertado do que estava se configurando na Cidade de Roma. Dion Cássio afirma ${ }^{746}$ que Tibério passara a elogiá-lo e denunciá-lo simultaneamente e com a mesma intensidade, honrando e difamando amigos de Sejano, deixando-o temeroso: nunca teria Ihe incorrido a ideia de promover uma revolução, conquanto se mantivesse ainda em sua proeminente posição, e tampouco de agir ousadamente, visto que estivesse sendo frequentemente rebaixado.

Em meio a isto, a população também teria permanecido em suspense, em um constante estado de dúvida, ouvindo alternadamente relatos contraditórios em breves intervalos, e sem condições precisas tanto para manter o apoio a Sejano quanto para menosprezá-lo, ao passo que em relação a Tibério todos se questionavam se ele estava prestes a morrer ou se retornaria para Roma ${ }^{747}$. A aristocracia começara a temer por sua própria segurança, conquanto publicamente ainda demonstrassem respeito a Sejano, uma vez que este último, seus filhos e também Gaio César foram condecorados com o sacerdócio; Sejano recebera também o imperium proconsular, realçado pela determinação de que os cônsules passassem a emular sua conduta no cargo. Todavia, quando Sejano requisitara permissão para ir para Campânia, Tibério teria respondido-Ihe para que permanecesse em

\footnotetext{
${ }^{746} 58.6 .4$.

${ }^{747}$ Dion Cássio, 58.6.5.
} 
Roma, pois estaria se preparando para retornar à Cidade quase que imediatamente $^{748}$.

Paralelamente, outros pressupostos políticos teriam sido igualmente importantes para determinar a frágil situação de Sejano, a tênue posição de seus associados, e a instabilidade do panorama político da aristocracia senatorial e equestre em Roma. Dentre eles, teria havido o fato de que Tibério, após apontar Gaio César como sacerdote, apresentara algumas indicações que pretendia fazer do jovem príncipe o sucessor imperial ${ }^{749}$. Consequentemente, esta predileção colocara Sejano em uma difícil posição política, e Dion Cássio argumenta ${ }^{750}$ que o prefeito do pretório poderia neste momento ter iniciado uma rebelião, o que teria the provocado um grande remorso porquanto os soldados estavam prontos para obedecer a todas as suas ordens, e do mesmo modo por ele não ter percebido que a população estava bastante agraciada pelas reverências feitas a Gaio César em decorrência da memória de seu pai, Germânico César, e pela percepção de que os senadores agora começassem a demonstrar um apoio incondicional ao jovem príncipe.

A situação política de Sejano estava evidentemente complicada. Tibério não se fizera presente durante o início do ano consular, e no dia oito de maio este abdicou do cargo $^{751}$. Embora não desconsideremos o fato de que a promoção de Sejano pode ter sido genuína, este último certamente percebera que a ida de Gaio César para Capri e a negação de sua própria presença na ilha era algo suspeito.

Em contrapartida, podemos considerar também que, pelo menos em princípio, aos olhos do Princeps a promoção de Sejano não teria significado uma contraposição à natural ascensão de Gaio César ou Tibério Gemelo, mas uma vez que até então Gaio César havia sido mantido em uma posição secundária em moldes semelhantes aos de Agripa Póstumo, a hipótese de desconfiança da parte de Tibério com Sejano certamente fora o fator mais plausível para uma mudança de planos. De acordo com Ann Bodington ${ }^{752}$,

\footnotetext{
${ }^{748}$ Idem, 58.7.4-5.

749 Dion Cássio, 58.8.1.

750 Idem, 58.8.2.

751 ILS 6124:15; Cf. Suetônio, Vida de Tibério, 26.1.

752 1963, p. 16.
} 
pode ter havido uma tensão entre os associados de Tibério reticentes ou abertamente contrários à posição conquistada por Sejano, e nesse ínterim provavelmente os desígnios do prefeito do pretório teriam sido revelados, com uma margem de tempo suficiente para que a sua eliminação fosse realizada sem uma perturbação mais grave no Senado ou uma rebelião militar.

Outro fator que conduzira Sejano ao isolamento político fora uma a anulação de um processo criminal contra aquele que anos antes fora indicado para governar a província da Hispânia [L. Arrúntio] ${ }^{753}$. Para tanto, Tibério assegurara imunidade - durante o intervalo anterior à ascensão ao cargo para todos aqueles que foram designados para o governo das províncias ou para o envolvimento com outros negócios públicos. O Princeps também deixara subitamente de referir-se a Sejano com os títulos costumeiramente agregados em suas correspondências ao Senado, proibira a realização de libações e proposição de honras para si - fato costumeiramente negado desde o início de seu governo - e consequentemente para Sejano ${ }^{754}$.

Por fim, membros da aristocracia passaram a evitá-lo, o que servira como ponto de partida para que Tibério agisse ${ }^{755}$. De tal modo, este último anunciara publicamente a concessão do poder tribunício a Sejano, e simultaneamente uma correspondência ao também cônsul Mêmio Régulo chegara pelas mãos de Névio Sutório Macro - secretamente apontado pelo Princeps como novo prefeito da guarda - contendo ataques a Sejano e instruções para Grecínio Laco, comandante da guarda noturna ${ }^{756}$.

No dia seguinte, Macro encontrara Sejano e revelara que trazia o anúncio da proposição do poder tribunício. Este último seguira para o Senado enquanto o primeiro reagrupara a guarda pretoriana, tendo a eles anunciado simultaneamente que era o novo prefeito e que o Princeps havia concedidoIhes recompensas ${ }^{757}$. Com o Senado cercado pelos pretorianos e pela guarda noturna, a correspondência lida aos senadores não contivera acusações formais, apenas reprimendas e a instrução de que dois senadores íntimos de

\footnotetext{
${ }^{753}$ L. Arrúntio, governador da Hispânia Citerior Tarraconense, nomeado em 23 d.C., embora tenha permanecido em Roma durante todo o cargo. Aélio Lâmia, governador da Síria desde 21 d.C., também permaneceu na capital até sua morte em 33 d.C. Cf. Tácito, Anais, 6.27.2-3. L. Arrúntio foi notadamente um dos principais opositores de Sejano, e posteriormente de Macro.

${ }^{754}$ Dion Cássio, 58.8.3-4.

${ }^{755}$ Idem, 58.9.1.

756 Ibidem, 58.9.2-3.

757 Ibidem, 58.9.4-5.
} 
Sejano deveriam ser punidos; Tibério abstivera-se de pedir sua execução por temer consequentes perturbações, e inclusive solicitara que um dos cônsules estivesse com ele caso fosse necessário retornar a Roma ${ }^{758}$.

A reação de perplexidade fizera com que mesmo os senadores mais próximos de Sejano o isolassem; os pretores e tribunos imediatamente teriam se aproximado dele de modo a evitar qualquer perturbação, e após a leitura da correspondência, Mêmio Régulo convocara Sejano a se levantar. Em meio a um Senado em polvorosa, o cônsul não propusera nem que os senadores votassem e tampouco que houvesse pena capital, por temer a irrupção de oposições e consequentes perturbações em decorrência do grande número de amigos e parentes de Sejano; ao invés disso, apenas questionou a um único senador se Sejano não deveria ser preso, e diante de uma resposta afirmativa Sejano foi retirado do Senado sob a escolta de Laco e outros magistrados diretamente para a prisão ${ }^{759}$.

A reação popular não demorara, e embora o Senado tivesse decidido inicialmente apenas manter Sejano aprisionado, as grandes manifestações próximas ao recinto e a ausência da guarda pretoriana precipitaram sua imediata execução e a de seus familiares, à exceção de sua ex-esposa Apicata, que após ter revelado em carta ao Princeps o envolvimento de Sejano e de Lívia Júlia para o envenenamento de Druso Cláudio ano, cometera suicídio $^{760}$.

Após sua execução, Dion Cássio complementa ${ }^{761}$ que além da revolta da população, da destruição de efígies do falecido, e de uma dita perseguição aos seus associados, os pretorianos, enfurecidos por terem sido considerados suspeitos de lealdade a Sejano e preteridos aos soldados da guarda-noturna, promoveram saques e incêndios em Roma. $O$ receio em relação à guarda teria sido o pretexto para que Tibério mantivesse embarcações prontas para escapar de Capri caso Sejano ordenasse uma revolução, e da mesma maneira - Princeps teria ordenado a Macro que em caso de um levante trouxesse

\footnotetext{
${ }^{758}$ Ibidem, 58.10.1-2.

${ }^{759}$ Dion Cássio, 58.10.4-8.

${ }^{760} \mathrm{Idem}, 58.11 .1-7$.

${ }^{761} 58.12 .2$.
} 
Druso, filho mais velho de Germânico César, perante o Senado e o povo e que o proclamasse Imperador ${ }^{762}$.

Uma vez que nada disso ocorrera, Dion Cássio complementa ${ }^{763}$ que ao saber da morte de Sejano, Tibério teria ficado mais aliviado, mas este fato não o impedira de recusar uma embaixada enviada para congratulá-lo, a despeito de muitos senadores e equestres terem rumado para a Campânia com esta intenção; nem mesmo o cônsul Mêmio Régulo teria sido recepcionado, embora este tivesse agido pelos interesses do Princeps e se prontificado a acompanhar a escolta do Imperador em uma eventual jornada de retorno para Roma na dada ocasião ${ }^{764}$.

Diante do impacto imediato da eliminação de Sejano, o Senado também teria se alvoroçado; os membros da instituição que a ele se associaram passaram a temer represálias, especialmente aqueles que haviam acusado ou sido testemunhas de crimes de traição, em decorrência da suspeita de que Sejano se beneficiara com estes crimes. Podemos perceber em Dion Cássio ${ }^{765}$ certa ironia na descrição da reação dos membros da aristocracia após a eliminação de Sejano: este se tornara o responsável por praticamente todos os infortúnios anteriores, ignorantes de seus desígnios ou forçados a cooperar com ele; em foro privado esta teria sido a atitude de vários grupos, não obstante publicamente tivessem votado publicamente a libertação de uma tirania, a construção de uma estátua à liberdade no fórum, e a proibição expressa de luto para Sejano.

Por fim, Dion Cássio nos apresenta um interessante balanço da eliminação de Sejano, no que tangeu à importância de sua ascensão enquanto precedente inaugurador do poder e influência que o seu cargo, sua posição e o suporte da guarda pretoriana teriam durante o Principado:

Assim pereceu Sejano, após ter chegado a um poder maior do que qualquer um daqueles que detiveram esta posição antes ou depois dele, com a exceção de Plautiano ${ }^{766}$. Mais ainda, seus parentes, seus associados, e todo o resto que fazia a

\footnotetext{
${ }^{762}$ Ibidem, 58.13.2; Tácito, Anais, 6.23.2.

${ }^{763} 58.13 .2$.

${ }^{764}$ Dion Cássio, 58. 13.3.

${ }^{765} 58.12 .4$.

${ }^{766}$ Prefeito da guarda durante o governo de Septímio Severo (193-211 d.C.).
} 
corte para ele e havia proposto a concessão de honras para ele foram levados a julgamento. A maioria deles foi condenada pelos atos que anteriormente haviam os feito objetos de inveja; e os seus concidadãos os condenaram pelas medidas que eles mesmos haviam anteriormente votado. Muitos homens que haviam sido julgados por várias acusações e absolvidos foram novamente acusados e agora condenados, pela razão de que eles haviam sido salvos antes como um favor ao homem agora eliminado $^{767}$.

É interessante observarmos como a trajetória de Sejano influenciou o governo de Tibério e o destino político dos membros da família imperial e de sua corte. Podemos dizer que o Princeps sofreu sucessivos reveses na tentativa de se manter como o pater familias responsável pela administração do projeto dinástico concebido por Augusto, bem como grandes dificuldades em administrar as disputas e intrigas dentro da corte, definitivamente o cerne da política imperial, principalmente nesta etapa de experimentações que caracterizou o Principado em sua institucionalização.

Sejano interferiu significativamente na interação entre o Imperador, os núcleos familiares imperiais em disputa e os associados da aristocracia senatorial e equestre em Roma. Sua influência não se constituiu como a única razão que levou Tibério a se afastar para Capri, mas sua posição de braçodireito do Princeps influenciou a postura de Tibério em relação aos seus concidadãos desde então. A crescente credulidade na lealdade de Sejano, a fragilização da interlocução política em Roma, e a desconfiança em relação à sua própria permanência no poder constituíram a lente do caleidoscópio através do qual o Princeps passara a observar as interações políticas de Roma. Estas consequências relacionam-se ao fenômeno de inflexão política que foi o afastamento do Princeps para Capri, fato que constituiu um filtro político em virtude do seu desgaste e descrença com o ambiente da Capital, e contribuíram para delinear o foco pelo qual Tibério passara a enxergar boa parte das movimentações da aristocracia em Roma.

${ }^{767}$ Dion Cássio 58.14.1-2. 
Nesse sentido, de acordo com Barbara Levick e Robin Seager ${ }^{768}$, se o Princeps concebera o clímax hediondo transmitido pela literatura que assolara Roma após a queda de Sejano, e se sabia das intenções do Senado em proscrevê-lo, tudo é incerto, pois dificilmente ele teria tido um acesso claro às verdadeiras intenções por trás dos fatos. Desde 23 d.C., Sejano tornara-se o único e derradeiro assessor político, cuja vigilância o preservara contra as intenções de seus opositores, especialmente as de Agripina e seus associados, e seu suporte o ajudara a manter-se quando sua expectativa era a de que Druso pudesse assumir o fardo do Principado, e assegurar-Ihe o seu retiro dos afazeres da vida pública em Roma. Quando Tibério descobriu (ou foi notificado de) que, à semelhança das diretrizes para a sucessão dinástica, sua vida também parecia vulnerável, Sejano foi eliminado. Provavelmente, as denúncias de Apicata sobre o envenenamento de Druso - verdadeiras ou não contribuíram para recrudescer a angústia e ressentimento de Tibério, e com isso a eliminação massiva de qualquer possível apoiador de Sejano também pode ter sido pensada como vingança.

O prefeito do pretório destruíra o esquema de sucessão dinástica concebido por Augusto e desenvolvido por Tibério, e tentara nesse ínterim introduzir a si e sua família dentro desse esquema; ele se tornara uma ameaça e uma fonte de desconforto tão evidente ao Princeps, seus remanescentes, e a uma parte significativa da aristocracia, que a única solução cabível fora a sua eliminação, junto de seus familiares e todos os possíveis apoiadores. E por fim, o caminho estava aberto agora para Gaio César, e junto a ele um novo prospecto para aqueles que com ele pudessem se associar.

\footnotetext{
${ }^{768} 1999$, p. 141 ; 2005, p. 187 . Cf. também Marsh (1931, p. 309-10): o período de "pânico" que teria ocorrido após a eliminação de Sejano - e a execução massiva de associados e conspiradores em potencial - pode ter significado também que alguns de seus apoiadores podem ter se envolvido em intrigas conspiratórias sem grande expressão, uma vez que perceberam que a eliminação de Tibério seria a única maneira de salvarem suas próprias vidas, uma vez que a menor vinculação tornou-se pressuposto para acusação e condenação.
} 


\subsection{2 - O caminho da transição}

Entre Roma e Capri, a ascensão de Sejano, sua interferência no governo de Tibério, e a sua eliminação foram importantes contrapontos que acompanharam nossa compreensão do afastamento do Princeps como ponto de inflexão política e viés pelo qual seu Principado tem sido analisado. Entre Tibério, sua corte (e seu deslocamento), a relação com a família imperial, a existência de novos atores dentro das redes de influência e favorecimento (Sejano, e a partir de sua deposição em 31 d.C., Macro), e o restante da aristocracia da Cidade de Roma, observamos que existiram variações no âmbito da patronagem imperial durante este período: longe de ter sido uma relação de poder unilateral entre o Princeps e seus concidadãos, existiu uma complexa rede de solidariedades especificas entre os membros da aristocracia e membros associados ao ambiente da corte imperial. Essas redes promoveram disputas por favorecimento e preponderância dentro de um sistema político em consolidação, cujo foco último, durante o governo de Tibério, constituiu-se da sucessão imperial.

Após a morte de Sejano, as delações, julgamentos e condenações pelo crime de traição não arrefeceram: o receio do Princeps diante de uma reação colateral à sua medida engendrada para a eliminação de seu principal braçodireito, bem como a sistemática eliminação dos eventuais e ou hipotéticos associados de Sejano nos anos posteriores à sua morte fizera com que 0 ambiente de terror e paranóia política se perpetuasse.

A eliminação de Sejano não trouxera um fim às ameaças de conspiração, mas transformou qualquer suspeita de articulação com este último em um trunfo na incessante busca por favorecimento que nutria as ambições da aristocracia; a maior parte das condenações posteriores à sua morte consistiu da supressão de seus apoiadores, amigos, e mesmo associados de pessoas próximas a ele. A prontidão dos acusados para buscarem qualquer maneira de fugir das acusações (o suicídio tornou-se o principal método) demonstra o temor que pairava na Cidade de Roma; alguns cidadãos buscavam demonstrar o quanto detestavam o eliminado, ao passo que outros 
tentavam se isentar de qualquer vínculo ou colaboração, uma difícil tarefa em uma sociedade em que a necessidade de se contrair relações de amizade e clientela era uma condição para ascensão e favorecimento ${ }^{769}$.

Outras condenações envolveram indivíduos que eram amigos ou pessoas próximas ao Princeps, fato que sugere o grande grau de insegurança e desconfiança de Tibério. Mas, além destes fatores, a idade avançada do Imperador, e a latente ascensão de Gaio César, apoiado por Macro, foi um aspecto decisivo para o desfecho político de seu governo. O centro do poder e das intrigas estava na corte instalada em Capri. Geralmente seu resultado era uma acusação no Senado, embora o sigilo da corte possa ter impedido que os autores do período tivessem acesso às estratégias, às alianças e às tramas que culminaram com a condenação de inúmeros aristocratas, e com o isolamento e a morte de membros da família imperial ${ }^{770}$.

Em 32 d.C., o Princeps saíra de Capri e se aproximara de Roma, tendo visitado os jardins imperiais às margens do Rio Tibre, não obstante sem atravessar os portões da Cidade; rapidamente mudara de ideia e resolvera retornar para a ilha ${ }^{771}$. Nesse ínterim, houve uma mudança no cerimonial de celebração do pacto anual de lealdade ao Princeps: até então preterido pelo próprio Tibério, e votado em uníssono pelos senadores, neste ano cada senador o fizera individualmente ${ }^{772}$.

Não sabemos se isto se repetira nos anos seguinte, mas a nosso ver isto representara a insegurança de que fossem eles, por algum motivo, acusados entre si de cumplicidade ou complacência com as ações de Sejano e/ou de deslealdade ao Princeps, fato perceptível pela diligência de alguns de seus membros ao condenar a memória de Lívia Júlia, bem como pela confiscação da propriedade de Sejano que, do erário público, fora transferida para a riqueza privada do Imperador ${ }^{773}$.

Neste ínterim, o senador Togônio Galo propusera no Senado que Tibério compilasse uma lista com nomes de senadores para que, mediante sorteio, vinte deles agissem como uma guarda armada a serviço do Imperador toda vez

\footnotetext{
${ }^{769}$ LEVICK, 1999, p. 162.

${ }^{770}$ LEVICK, 1999, p. 168.

771 Tácito, Anais, 6.1.1.

772 Dion Cássio, 58.17.1.

${ }^{773}$ Tácito, Anais, 6.2.1.
} 
que ele adentrasse a Cúria. Ridicularizada pelos demais, a proposição, além de desconsiderar que a guarda já impedia que cidadãos comuns entrassem na câmara, implicava em perigo para os próprios senadores, uma vez que afiançava que havia inimigos do Princeps no interior do Senado ${ }^{774}$. Mesmo assim, Tibério teria respondera que seria difícil escolher entre senadores jovens ou amadurecidos, com ou sem exercício de magistraturas, se estes deveriam ser sempre os mesmos ou substituídos periodicamente, bem como ver senadores armados substituindo soldados, condição de sobrevivência em sua opinião indigna ${ }^{775}$.

Por outro lado, outra proposição do retor Júnio Galio recebera uma severa reprimenda: este propusera que os veteranos da guarda pretoriana recebessem o privilégio de possuir assentos entre as quatorze primeiras fileiras do anfiteatro (reservadas a senadores e equestres). Tibério questionara energicamente qual era o interesse do primeiro no exército: havia ele pensando algo que não ocorrera na mente de Augusto, ou isto era uma tentativa de sedição advinda de um partidário de Sejano que desejava corromper as tropas?

Gálio fora imediatamente expulso do Senado e exilado, mas a atratividade da ilha de Lesbos, escolhida para seu exílio, fizera com que Tibério determinasse que ele ficasse preso em Roma, confinado nas residências dos magistrados ${ }^{776}$. Na mesma correspondência Tibério demandara punição contra o pretoriano Sexto Paconiano, acusado de ter sido escolhido por Sejano para assassinar Gaio César. Todavia, Paconiano fora absolvido e acusara ainda Latínio Latiário, mentor da eliminação de Títio Sabino, que por sua vez fora condenado ${ }^{777}$.

Igualmente, Hatério Agripa acusara Mêmio Régulo e Fulcínio Trio cônsules do ano anterior - de serem indolentes com as acusações trocadas entre si nas últimas semanas de cargo: o Senado não poderia tolerar a consciência culpada dos consulares e ignorar as acusações proferidas. De sua parte, Trio afirmara que se vingaria quando Tibério se fizesse presente no Senado, enquanto Régulo afirmara que o assunto deveria ser esquecido; Q.

\footnotetext{
${ }^{774}$ Dion Cássio, 58.17.3-4; Tácito, Anais, 6.2-3.

${ }^{775}$ Tácito, Anais, 6.4.

776 Dion Cássio, 58.18.3-4; Tácito, Anais, 6.3.1-3.

777 Tácito, Anais, 6.3.4, 6.4.1.
} 
Sanquínio Máximo interviera e afirmara que Tibério não deveria ser incomodado com ressentimentos recentes, pois sua solução seria ainda mais severa, e por fim a questão se resolvera, sem condenações, embora Agripa tivesse se tornado ainda mais odiado por sua fama de acusador ${ }^{778}$.

Cota Messalino, impopular por sua severidade, também foi acusado de zombar da virilidade de Gaio César e criticar a recusa de Tibério em conceder a deificação a Lívia Drusila. Após um embate com M. Lépido e L. Arrúntio, Messalino teria dito ainda que embora o Senado os protegessem, Tibério intercederia por ele; e de fato, quando os mais ilustres senadores o atacaram, o Princeps relembrara sua origem e seus serviços, ressaltando mais uma vez que observações fora de contexto e piadas contadas à mesa de jantar não deveriam ser pretextos para perseguição. Em contrapartida, Cesaliano, o principal acusador, foi imediatamente condenado e recebera a mesmo destino de Aruseio e Sangúnio, equestres acusadores de L. Arrúntio no ano anterior ${ }^{779}$.

Quinto Serveu, amigo de Germânico César, e Minúcio Termo, equestre associado de Sejano, também foram condenados. $O$ acusador foi $C$. Céstio, autorizado por Tibério após ter recebido sua correspondência, cujas denúncias foram repetidas no Senado, embora os condenados não tenham encontrado seu fim sem antes terem acusado Júlio Africano e Seio Quadrato por traição ${ }^{780}$. Assim como Dion Cássio - embora inserido nos comentários sobre o ano de 31 d.C. -, Tácito se vale deste episódio na narrativa para criticar a precipitação dos senadores à delação e a busca de recompensas pela denúncia indiscriminada de desafetos, antigos associados e até mesmo parentes ${ }^{781}$. A despeito do acento dramático, é interessante notarmos como a incoerência passou a fazer parte das decisões do Princeps sobre a veracidade das acusações, e da mesma forma a maneira indiscriminada pela qual parte dos senadores passara a se valer da compreensão e da utilização das leis. Por outro lado, a amizade de Sejano já não parecia o bastante: as acusações começaram a se parecer como uma ferramenta absolutamente eficaz, e muitas invectivas passaram a vir à tona simplesmente pelo fato de o contexto terem

\footnotetext{
${ }^{778}$ Tácito, Anais, 6.4.2-4.

${ }^{779}$ Suetônio, Vida de Tibério, 67.1; Tácito, Anais, 6.5-7.

${ }^{780}$ Tácito, Anais, 6.7.2-4.

781 Dion Cássio 58.14.4-5; Tácito, Anais, 6.7.3.
} 
feito delas pretextos convidativos para atacar aqueles que aparentemente não eram politicamente vulneráveis ${ }^{782}$.

Houve uma exceção: ainda durante 0 ano de 32 d.C. o eqüestre $M$. Terêncio, acusado de amizade com Sejano, concordara com a acusação, e afirmara ainda que conspirações contra o Estado e o soberano deveriam ser punidas, mas que a amizade contraída com o ex-prefeito, além de consideração à amizade e aos seus serviços, foi também consideração e amizade a César e, portanto, que esse fato absolvesse tanto o Princeps quanto os senadores ${ }^{783}$. O discurso de Terêncio desmobilizara seus acusadores, mas não impedira que outra correspondência trouxesse uma acusação simultânea dos consulares Asínio Pólio, seu filho Viciniano, Ápio Silano, Mamerco Escauro e Sabino Calvísio contra os mesmos vínculos de amizade com Sejano. Tácito complementa $^{784}$ que nesse contexto os senadores começaram a temer por suas vidas, pois muito poucos eram aqueles que não detinham conexões pessoais com homens tão ilustres.

Algumas acusações também podem ter sido instigadas por Gaio César e seu associados, especialmente se essas se constituíssem como insultos ou injurias ao jovem príncipe: Sexto Vistílio, amigo de Druso Nero, irmão de Tibério, também fora acusado por este último de ofensa contra o futuro Imperador. Contudo, desta vez o Princeps não demonstrara complacência semelhante como no caso de Cota Messalino: após a renúncia da amizade por parte do Imperador, Vistílio cortara os pulsos, não obstante tivesse ainda tentado, sem sucesso, reconquistar a estima de Tibério ${ }^{785}$.

O luto também fora causa de condenações: embora mulheres não pudessem ser acusadas de conspiração contra o Estado, Vítia, mãe de Fúfio Gemônio, foi condenada à morte por chorar a morte de seu filho ${ }^{786}$; Tibério introduzira a proibição do luto a qualquer associado com a condenação de Sejano ${ }^{787}$, e a despeito da severidade da medida, o luto por um condenado por traição poderia facilmente adquirir contornos políticos ${ }^{788}$.

\footnotetext{
782 LEVICK, 1999, p. 163.

783 Dion Cássio, 58.19.3-4; Tácito, Anais, 6.8.6.

784 Anais, 6.9.3.

785 Tácito, Anais, 6.9.2.

786 Idem, 6.10.1.

787 Suetônio, Vida de Tibério, 61.2.

788 SEAGER, 2005, p. 193.
} 
Se as acusações e condenações ocuparam o Senado em Roma, isto não significa dizer que a permanência na corte fora da Capital trazia imunidade. Possivelmente alguém também incitara acusações em Capri: dois amigos de longa data do Princeps, Vesculário Flaco e Júlio Marino, foram executados, mesmo ambos tendo sido companhias de Tibério em Rodes e Capri: o primeiro por ter auxiliado na condenação de Marco Escribônio Libo Druso, e o segundo como auxiliar de Sejano na eliminação de Cúrtio Ático. Ainda em referência às companhias de Tibério na corte, o ano de 32 d.C. trouxe a morte de L. Calpúrnio Pison, que além de pontífice, fora prefeito da Cidade de Roma durante quase todo o governo de Tibério, e assim privado de mais um importante aliado político; após o recebimento de honras fúnebres, foi sucedido por Aélio Lâmia ${ }^{789}$. Por fim, o ano de 32 d.C. ainda vira a execução dos equestres Gemínio, Celso e Pompeu, todos acusados por cumplicidade na conspiração de Sejano ${ }^{790}$.

Em 33 d.C., Gaio César assumira o cargo de questor, conferindo-lhe acesso ao Senado ${ }^{791}$. Sua posição de potencial sucessor estava muito melhor assegurada do que a de Tibério Gemelo, caso tivesse havido qualquer pretensão de disputa. Toda a popularidade de Germânico César, Agripina e seus irmãos direcionaram-se à sua pessoa, uma vez que estes foram isolados politicamente. Em contrapartida, Tibério Gemelo, por ser filho de Druso Cláudio e neto consanguíneo de Tibério, provavelmente era menos popular, além de oito anos mais novo do que Gaio César (Gemelo nascera em 19 d.C.), que já havia assumido a toga viril e adentrara à carreira pública com vinte e um anos. Igualmente, este último recebera como esposa Cláudia, filha de M. Silano; para tanto Tibério aportara novamente no continente e aproximara-se da Cidade de Roma, e em Antium celebrara um festival em homenagem a este matrimônio ${ }^{792}$. Certamente, tanto a ascensão ao Senado quanto o casamento devem ter servido como maneira de consolidar sua posição como futuro Princeps, haja vista que logo depois Druso morreria.

Além do casamento de Gaio César, Tibério também tivera a intenção de resolver os arranjos matrimoniais para as filhas remanescentes de Germânico

\footnotetext{
789 Tácito, Anais, 6.10.3; Dion Cássio, 58.19.5; Suetônio, Vida de Tibério, 42.1.

${ }^{790}$ Tácito, Anais, 6.14.1.

${ }^{791}$ Dion Cássio, 58.23.1.

792 Tácito, Anais, 6.20.1; Dion Cássio 58.25.2.
} 
César: Drusila e Júlia já tinham dezesseis e quinze anos, respectivamente; a primeira foi prometida para Cássio Longino (cônsul em 30 d.C.), e para a segunda M. Vinício, colega de consulado no mesmo ano e patrono de Veléio Patérculo. Júlia, filha de Druso Cláudio e que anteriormente fora casada com Nero, casara-se novamente com o consular Rubélio Blando, cujo pai fora de origem equestre; este casamento gerara certa animosidade na população ${ }^{793}$.

Com estes arranjos, é possível que Tibério também não desejasse que seu neto Gemelo fosse prejudicado no esquema sucessório, e para tanto existem duas constatações: em primeiro lugar, o Princeps quis evitar a entrada de possíveis usurpadores do poder imperial: Agripina Menor casou-se com Gneio Domício Aenobarbo, que fora neto de Otávia e sobrinho-neto de Augusto, e se caso Gaio César ou Tibério Gemelo falecessem, o primeiro poderia ser uma opção para o Principado. Já Cassio Longino, Marco Vinício e Rubélio Blando eram respectivamente descendentes de uma família plebeia republicana e os demais de origem equestre, o que ceifara os prospectos de competição entre as filhas mais novas de Germânico César e a filha remanescente de Druso Cláudio; o controle pela ascensão ao poder permaneceria nas mãos dos homens da família imperial, pelo menos até a morte de Tibério.

Entretanto, o par sucessório Gaio César/Tibério Gemelo fora a estratégia preferida pelo Princeps, e isto pode ser observado mediante a interpretação do significado político presente na cunhagem imperial durante os últimos anos do governo de seu governo. Nestas moedas, clementia e moderatio são descritas e representadas no anverso, cada uma portando um escudo preenchido por um pequeno e jovem busto $^{794}$. Excluídos Tibério, Germânico César e Druso Cláudio como os possíveis representados, existe uma presumível relação com a sucessão, pois os escudos são semelhantes aos concernentes à memória dos falecidos príncipes, ambas as virtudes são referentes a Tibério, sua clementia em relação a Agripina celebrada neste mesmo ano, e sua moderatio permite que seu filho o suceda; os bustos representam seus netos Gaio César

\footnotetext{
793 Tácito, Anais, 6.27.

${ }^{794}$ RIC 38, 39, 40.
} 
e Tibério Gemelo, os quais o Princeps visou divulgar deste modo como os prováveis sucessores ${ }^{795}$.

Nesse ínterim, Tibério pedira ao Senado, além de desculpas por sua ausência, autorização para adentrar o Senado acompanhado de Macro e uma pequena escolta de soldados, em razão das inimizades contraídas pela defesa do Estado; o Senado aprovara sua solicitação e adicionara uma cláusula que previa que seus membros fossem revistados durante a entrada. Embora sua iniciativa pareça incoerente à reação contra Togônio Galo no ano anterior, existem diferenças: além do ressentimento pela escolha de alguns senadores em detrimento de outros, estes seriam guardas com os quais Tibério certamente teria tido um maior vínculo de confiança ${ }^{796}$.

Paralelamente, as perseguições continuaram e Tácito expõe a acusação por traição de Consídio Próculo, senador que celebrava seu aniversário quando foi subitamente conduzido para a câmara senatorial, condenado e executado; juntamente a Próculo, sua irmã Sância foi condenada ao exílio mediante a acusação de Q. Pômponio. Em seguida, Sexto Mário, um antigo amigo de Tibério, e que se tornara o mais rico cidadão romano na Hispânia em decorrência do favorecimento do Princeps, foi denunciado por incesto com sua filha e lançado da rocha Tarpéia; Tibério teria se apropriado de suas minas de ouro e prata ${ }^{797}$. Contudo, como ocorrera no caso de Sejano, é possível que sua riqueza tenha advindo em parte de concessões do Princeps ${ }^{798}$. Tácito afirma ainda $^{799}$ que Tibério ordenara ao longo do ano que todos aqueles mantidos em cárcere pelo envolvimento com Sejano fossem executados. Suetônio afirma ${ }^{800}$ que o Princeps mandara executar vinte envolvidos em um único dia; provavelmente esta menção, embora sem referências precisas, relacione-se a

\footnotetext{
795 GESCHE, 1971, p. 37 apud LEVICK 1999, p. 167. Entretanto, a data de cunhagem deste conjunto de moedas é bastante discutida. Sutherland (1984, p. 88-9) apresenta a ampla variedade de prováveis datas: 16, 22 ou 34-7 d.C., mas conclui que a despeito das possíveis interpretações históricas das imagens no reverso destas moedas, os aspectos artísticos de elaboração conduzem sem maiores dúvidas à conclusão de que estas foram cunhadas no início do governo de Tibério. Cf. também SUTHERLAND, 1938, p. 136-7.

${ }_{797}^{796}$ SEAGER, 2005, p. 194.

${ }^{797}$ Dion Cássio, 58.22; Tácito, Anais, 6.19.1.

${ }^{798}$ SEAGER, 2005, p. 175.

${ }^{799}$ Anais, 6.19.2-3.

${ }^{800}$ Vida de Tibério, 61.4.
} 
este contexto, mesmo que prováveis condenados tenham permanecido vivos: Pompônio Segundo, Sexto Paconiano, entre outros ${ }^{801}$.

Todavia, durante este ano outras mortes foram paradigmáticas para 0 futuro do Principado. Tácito afirma ${ }^{802}$ que a morte de Asínio Galo repercutira publicamente; embora fosse certo que Galo tivesse morrido de fome, não se sabia ao certo se fora suicídio; na ocasião Tibério lamentara publicamente o fato de que o Senador morrera antes de receber o julgamento que merecia. Druso também sucumbira por inanição, embora alguns acreditassem que ele e Agripina escapariam da eliminação após a morte de Sejano.

Contudo, a manifestação pública do Princeps sobre o fato demonstrara algo diferente: em sua correspondência, Tibério criticara Druso por sua conduta imoral, hostilidade ao seu falecido irmão Nero e vilania contra o Estado. Diante de um Senado atônito, o Imperador demandara que fosse feita a leitura de todo o registro do cotidiano de Druso, desde o dia em que começara a suspeitar de suas intenções até suas últimas palavras, bem como suas últimas imprecações contra o Princeps em seu leito de morte ao Senado ${ }^{803}$.

Logo depois, Tácito complementa $^{804}$ que Agripina, que teria permanecido viva após a eliminação de Sejano por nutrir expectativas de reabilitação, também morrera de fome - por espontânea vontade ou não, fato também incerto - quando percebera que, com a morte de seu filho, dificilmente sua situação melhoraria. Novamente e por correspondência, Tibério revelara ao Senado a acusação de que Agripina teria cometido adultério com Asínio Galo, e que a morte deste último lhe trouxera aversão à vida. Mais ainda, Tibério complementara que sua morte tivera lugar na mesma data em que Sejano morrera, uma coincidência que deveria ser perpetuada pela memória, e por fim gabara-se de que ela não havia sido nem estrangulada e tampouco tivera seu corpo lançado escada gemoniana abaixo. Em retribuição, o Senado decretara que, a partir de então, no dia dezoito de outubro (dia de cada execução) uma dádiva fosse sempre consagrada a Júpiter.

\footnotetext{
${ }^{801}$ SEAGER, 2005, p. 196; EJ 43.

${ }^{802}$ Anais, 6.23.1.

${ }^{803}$ Tácito, Anais, 6.24.1-3.

${ }^{804}$ Idem, 6.25.1-3.
} 
Ao suicido de Agripina seguira-se o de Plancina ${ }^{805}$, embora nada se saiba sobre as causas, e o senador M. Coceio Nerva, único senador presente na comitiva que acompanhou Tibério para Capri e companhia constante do Imperador, também resolvera cometer suicídio ${ }^{806}$. Quando soubera da decisão deste último, Tibério teria sentado ao seu lado, questionado seus motivos, adicionado súplicas, e por fim confessara que o suicídio traria sérias consequências para a consciência do Princeps e sua reputação se o mais íntimo de seus amigos abandonasse a vida sem razões para tanto. Mas Nerva manteve-se resoluto e abandonou-se à fome: aqueles que conheciam seus pensamentos sabiam que, na medida em que sua raiva e medo aumentavam diante do desfecho do governo de Tibério, ele desejava uma morte honrosa e imaculável.

Com a chegada de 34 d.C. os cônsules Paulo F. Pérsico e L. Vitélio celebraram o vigésimo aniversário da ascensão de Tibério ao poder e a renovação de seu imperium. Contudo, Dion Cássio afirma ${ }^{807}$ que as condenações continuaram simultaneamente às celebrações: desta vez nenhum deles fora absolvido, mas todos condenados mediante correspondências de Tibério, cujas acusações teriam sido obtidas por meio da aplicação sistemática de torturas coordenadas por Macro. O Princeps uma vez mais estava no continente (próximo a Túsculo), mas novamente não ousara entrar em Roma: segundo rumores, a real motivação para Tibério não voltar à Cidade teria sido a de evitar ser desonrado quando as sentenças fossem pronunciadas ${ }^{808}$.

Como exemplo, Pompônio Labeo, que estivera encarregado do governo da província da Moésia, cometera suicídio ${ }^{809}$. Tácito acrescenta ${ }^{810}$ que o temor da execução seria a explicação de tantos suicídios, por causa da confiscação dos bens dos condenados e da proibição ao sepultamento, enquanto que aqueles que cometessem suicídio mantinham o testamento e corpo enterrados, um prêmio pela precipitação. Em consideração ao suicídio de Pompônio Labeo, Tibério pronunciara-se por correspondência ao Senado reiterando que, sempre que seus ancestrais rompiam amizades, havia sido costume afastar a pessoa

\footnotetext{
${ }^{805}$ Dion Cássio, 58.22.5; Tácito, Anais, 6.26.3.

${ }^{806}$ Dion Cássio, 58.21.4; Tácito, Anais, 6.26.2-3.

${ }^{807}$ 58.24.1-2.

${ }^{808}$ Dion Cássio, 58.24.2.

${ }^{809}$ Tácito, Anais, 6.29.1; Dion Cássio, 58.24.3.

${ }^{810}$ Anais, 6.29.1-2.
} 
da residência e pôr um fim à cordialidade: esta havia sido sua iniciativa neste caso. Mais ainda, pelo fato de Labeo ter sido acusado de má administração em sua província e outros crimes, Tibério concluíra que ele mesmo encobrira sua culpa mediante um ato destinado a causar ressentimento, e com um desnecessário amedrontamento de sua esposa que, embora culpável, todavia não compartilhava do mesmo risco ${ }^{811}$.

De modo semelhante, Mamerco Escauro fora novamente acusado de traição por adultério com Lívia Júlia, embora a real motivação da hostilidade tivesse sido um verso de sua tragédia Atreus, cuja associação metafórica com a tirania do Princeps fora explorada por Macro, que apresentara a obra ao Princeps. Escauro e sua esposa cometeram suicídio, mas seus acusadores, Servílio e Cornélio acabaram exilados por terem recebido suborno como recompensa por uma acusação contra Vário Ligo ${ }^{812}$. Por último, este ano ainda contivera mais uma tentativa de condenação por associação à conspiração de Sejano: o ex-edil Abúdio Ruso, que comandou uma legião sob as ordens de Lentulo Getúlico, atacou este último pelo seu anterior noivado com uma das filhas de Sejano. Contudo, a popularidade de Getúlico entre as legiões estacionadas às margens superiores do Rio Reno, bem como o comando de seu sogro, L. Aprônio, na outra margem, teria sido motivo suficiente para que 0 primeiro escrevesse uma correspondência a Tibério alegando que, por terem cometido o mesmo erro em associar-se a Sejano, seria injusto que enquanto outros pagassem por isso, o Princeps saísse ileso. Este recado ficara muito claro para Tibério: Getúlico continuara em sua posição, ao passo que Abúdio Ruso fora condenado e exilado ${ }^{813}$.

Em 35 d.C., o consular Fulcínio Trio fora novamente acusado, mas cometera suicídio antes da instauração do processo. Em seu testamento - a despeito da tentativa de seus herdeiros de suprimi-lo - Trio ataca Macro, os libertos imperiais e o próprio Princeps, criticando sua senilidade e seu exílio. Para Tácito ${ }^{814}$, a autorização de Tibério para a leitura das críticas proviera de duas razões: ou Tibério desejava demonstrar sua tolerância à liberdade de expressão e sua indiferença em relação à opinião alheia, ou sua experiência

\footnotetext{
811 Tácito, Anais, 6.29.2.

812 Tácito, Anais, 6.29.3-4, 30.1; Suetônio, Vida de Tibério, 61.3; Dion Cássio 58.24.3.

813 Tácito, Anais, 6.30.1-3.

814 Anais, 6.38.2-4.
} 
com Sejano teria o convencido de que melhor seria se a verdade sempre viesse à tona, independente do custo aos seus próprios sentimentos e reputação ${ }^{815}$.

O resto deste ano e os dois últimos anos de governo de Tibério apresentaram mais algumas acusações, suicídios e condenações. Ainda em 35 d.C., Grânio Marciano cometeu suicídio por ter sido acusado por C. Graco, e o ex-pretor Tário Graciano foi executado, ambos os casos sem maiores detalhes; Sexto Paconiano foi estrangulado na prisão por ter passado a maior parte de seu tempo escrevendo chacotas sobre Tibério ${ }^{816}$.

Em 36 d.C., o equestre Vibuleno Agripa envenenara-se no Senado, mas ainda sim foi conduzido à prisão e estrangulado, de modo que seu suicídio não impedira a confiscação de seus bens; Tigranes IV, ex-rei da Armênia, também fora condenado e executado, embora sem maiores detalhes. Ao mesmo tempo, C. Galba (cônsul de 22 d.C.), cometeu suicídio por ter seu nome sido banido para a candidatura ao governo da Ásia e África; igualmente, Q. Bleso (cônsul em 26 d.C.) e seu irmão, uma vez que não ascenderam ao prometido sacerdócio - provavelmente em decorrência da eliminação de seu pai Seio Estrabo - interpretaram o fato como um mau-sinal e também cometeram suicídio; Emília Lépida, ex-esposa de Druso, filho de Germânico, também cometeu suicídio para evitar inequívoca condenação por adultério com um escravo $^{817}$.

Por fim, em 37 d.C., Acútia, viúva de P. Vitélio, foi acusada de traição por D. Lélio Balbo e condenada, embora o recebimento da recompensa tenha sido vetado pelo tribuno J. Óton (Lélio logo seria expulso do Senado e exilado); Albucila, viúva de Sátrio Segundo, foi acusada de profanar o nome de Tibério e adultério com Domício Aenobarbo, Víbio Marso e L. Arrúntio. Este caso gerara suspeitas no Senado: as correspondências demonstraram que Macro havia coordenado a tortura dos escravos para obtenção da confissão, enquanto que Tibério não tivera conhecimento do caso.

Do mesmo modo como fora desafeto de Sejano, Arrúntio também se tornara desafeto de Macro, e ao passo que Víbio Marso e Domício Aenobarbo

\footnotetext{
815 Dion Cássio, 58.25.2.

816 Tácito, Anais, 6.39.1-2; Suetônio, Vida de Tibério, 61.6.

817 Tácito, Anais, 6.40.1-3.
} 
não cometeram suicídio, tanto Arrúntio quanto sua esposa Albucila tentaram evitar a condenação, o primeiro tendo argumentado que, mesmo que escapasse da condenação durante o governo de Tibério, certamente não sobreviveria durante o governo de Gaio César; Albucila não tivera sucesso com a tentativa de suicídio, tendo sido aprisionada e executada sob ordens do Senado ${ }^{818}$.

Neste contexto, Macro aparece como um dos principais responsáveis pelas mortes de Escauro e Fulcínio Trio; podem ter havido outros, mas é difícil mensurar o seu grau de envolvimento, assim como o de Gaio César e outros nos bastidores de várias condenações, suicídios e exílios. Contudo, na medida em que se afirmara no controle da guarda pretoriana, sua influência aparentemente crescera durante os últimos anos de governo de Tibério. Embora isto não o deixasse imune a qualquer reviravolta nos interesses do futuro novo Princeps, Macro - bem como uma parcela significativa da corte imperial - esperava uma rápida e suave ascensão quando o poder fosse transmitido, mesmo que Gaio César não detivesse os mesmos poderes que Tibério recebera de Augusto antes de 14 d.C., a saber, o imperium e o poder tribunício. E conquanto os últimos anos do governo de Tibério sejam transmitidos como um período de "terror" nas narrativas literárias, a compreensão histórica deste contexto deve ser empreendida de uma maneira que transcenda a análise quantitativa sobre a quantidade de acusados, condenados, executados, exilados e daqueles que cometeram suicídio.

Mesmo diante deste esforço, não teríamos como assegurar a credibilidade destes números: Tácito deve ter escolhido casos emblemáticos que justificaram, acima de qualquer outra coisa, o propósito de sua narrativa, por mais que esta seja comparativamente melhor detalhada. Por outro lado, a histeria política que provocara pânico nas sessões senatoriais é muito bem delineada, pois acusadores adquiriram liberdade para infligirem acusações sem uma rígida necessidade de provas, e o veredito não se tornou algo dependente de uma acareação sistemática e racional da veracidade das provas, mas sim do ímpeto ou julgamento do Princeps, distante da Cidade de Roma e alheio a uma análise circunstancial dos casos: ao mesmo tempo em que Tibério

${ }^{818}$ Tácito, Anais, 6.47-9; Dion Cássio, 58.27.2-4. 
apresentou a antiga moderação dos primeiros anos pela absolvição de Cota Messalino, o destino de Júnio Galio e Mamerco Escauro demonstrara que, no que dizia respeito à condenação por traição, tudo podia ser incerto e imprevisível.

Essa atmosfera de pouca racionalidade no que tangeu às questões de vida e morte estimulou o suicídio, que de uma atitude drástica passou a ser um desfecho preferível ao fim do favorecimento, à infâmia, e à possibilidade de confiscação dos bens que manteriam o prestígio e a continuidade das famílias senatoriais e equestres ${ }^{819}$. Durante os últimos anos de governo de Tibério, o Princeps, cada vez mais isolado e alheio com sua corte em Capri quando o assunto dizia respeito ao futuro dos seus concidadãos na roda do poder, tornara-se gradualmente menos sensível às perseguições senatoriais em Roma, menos interessado na aplicação das leis, mais maleável nas mãos daqueles que the deveriam ser úteis, ciente da inevitabilidade da ascensão de Gaio César e da promoção de seus amigos e clientes ${ }^{820}$. Aos que continuariam vivos para ver o próximo governo, a solução seria apostar na força do favorecimento ao associar à rede de solidariedades do futuro Princeps e dos indivíduos próximos a ele na corte; aos demais - principalmente os opositores ou aqueles cujos vínculos com Tibério e associados não thes parecia uma garantia segura - possivelmente os próximos anos se pareceriam muito com o presente em que estavam vivendo.

Finalmente, sobre 0 ano de 37 d.C. Tácito afirma ${ }^{821}$ que logo em seu começo o poder já era excessivamente exercido por Macro que, cotidianamente, estava promovendo cada vez mais a popularidade de Gaio César. Após a morte de sua esposa Cláudia, Macro teria induzido Ênia, sua própria esposa, a seduzi-lo, e por meio de um acordo matrimonial cooptá-lo, embora Suetônio afirme ${ }^{822}$ contrariamente que Gaio César teria the seduzido com a promessa de casamento caso ele ascendesse ao poder.

Tácito complementa ${ }^{823}$ que tudo isto era sabido por Tibério, que incerto e exausto fisicamente, optara deixar a escolha a cargo do destino, embora

\footnotetext{
${ }^{819}$ SEAGER, 2005, p. 202.

${ }^{820}$ LEVICK, 1999, p. 171-2.

${ }^{821}$ Anais, 6.45.3; Dion Cássio, 58.28.4.

${ }^{822}$ Vida de Calígula, 12.2.

${ }^{823}$ Anais, 6.46.1-3.
} 
preferisse Tibério Gemelo por parentesco e afeição, conquanto soubesse que sua pouca idade e o entusiasmo popular pelo descendente de Germânico César, sua própria impopularidade, o fato de Cláudio não ser uma opção plausível, e do temor de que a escolha de alguém fora da família imperial comprometesse a memória de Augusto e a reputação dos Césares. Tibério teria ainda ironicamente parabenizado Macro pela sua perspicácia em aderir àquele que estava ascendendo e, além de ter dito ocasionalmente para Gaio César que ele havia herdado todos os vícios de Lúcio Cornélio Sula, mas nenhuma de suas virtudes, em outro momento, tendo abraçado em lagrimas Tibério Gemelo, profetizara para Gaio César, enquanto este o olhava com indiferença, predizendo a ele que da mesma forma que Gaio mataria Gemelo, outro o mataria também ${ }^{824}$.

No mês de março, após ter visitado os arredores de Roma e enquanto estava no trajeto de retorno para Capri, Tibério adoecera na localidade de Astúria, região da Campânia. Após se recobrar novamente, prosseguir pela região e uma vez mais convalescer, finalmente ele chegara a Miseno, onde se instalara em uma villa que anteriormente havia pertencido a L. Lúculo, onde descobrira que seu fim se aproximava; embora Tibério tivesse evitado o tempo todo se consultar com seu doutor, Cáricles, este conseguira tomar seu pulso em um banquete e alertar o então impaciente Macro que o Princeps não teria mais que dois dias de vida ${ }^{825}$.

Tibério falecera no dia dezessete de março, aos setenta e oito anos de idade. Tácito afirma ${ }^{826}$ que após o diagnóstico de Macro, tudo fora rapidamente organizado mediante conversações entre aqueles que estavam presentes no último banquete do Princeps, e correspondências teriam sido enviadas para os legados e para as tropas. Com a respiração sufocada, acreditava-se que ele havia expirado, e em meio a uma multidão de apoiadores Gaio César se preparava para assumir o comando quando subitamente vieram notícias de que Tibério recobrara sua voz e visão, e que ele estava ordenando que the dessem comida para que se restabelecesse. Este fato teria provocado pânico e consternação, ao passo que Gaio César ficara atônito em meio às suas amplas

\footnotetext{
${ }^{824}$ Tácito, Anais, 6.46.4.

${ }^{825}$ Tácito, Anais, 6.50.1-3; Suetônio, Vida de Tibério, 72.2-3; Calígula, 12.2; Dion Cássio 58.28.1.

${ }^{826}$ Anais, 6.50.4-5.
} 
expectativas. Nesse ínterim, Macro teria por fim ordenado que o Princeps fosse sufocado com a própria roupa de cama.

Dion Cássio acrescenta ${ }^{827}$ a essa versão que em verdade Gaio César, temeroso de que Tibério pudesse recobrar sua saúde, recusou-Ihe comida tendo alegado que isto poderia prejudicar o quadro do Princeps, e fingindo melhor aquecê-lo com mais roupas de cama, ele mesmo o sufocara, com alguma ajuda de Macro. De sua parte, Suetônio, além de citar esta versão da morte de Tibério, especula outras possibilidades: Gaio César teria administrado um veneno que lentamente matara o Imperador, ou que durante a convalescência decorrente de uma forte febre, a comida fora-Ihe recusada, ou mesmo que, quando pedira por seu anel após um desmaio, o futuro Princeps o sufocara com um travesseiro. Suetônio ainda menciona ${ }^{828}$ Sêneca, que teria escrito que Tibério, ciente de seu fim, retirara o anel de seu dedo, como se fosse entregá-lo a alguém, mas teria por fim o colocado de volta e, tendo o forçado contra sua mão esquerda, permanecera imóvel por bastante tempo; ao clamar por seus ajudantes sem resposta, tentara-se levantar e caíra morto próximo de sua cama.

Não podemos afirmar como de fato morrera Tibério. Por outro lado, Suetônio afirma ${ }^{829}$ que a população se alegrara tanto com as primeiras notícias de sua morte que alguns começaram a correr gritando pedindo para que Tibério fosse lançado no Rio Tibre, enquanto outros clamaram aos deuses para que o morto só fosse aceito entre os condenados, e outros ainda que seu corpo fosse ultrajado na escada gemoniana, em memória de sua crueldade. De todo modo, o corpo do falecido Princeps fora conduzido por uma escolta militar entre Miseno e Roma; Gaio César acompanhara o cortejo, que adentrou a Cidade em vinte e nove de março. Seu testamento fora lido no Senado por Macro: Gaio César e Tibério Gemelo teriam sido nomeados como coerdeiros, Cláudio fora recomendado ao Senado, ao povo e às legiões, concessões de dinheiro para a guarda pretoriana, os soldados e o povo.

Por fim, os cônsules determinaram que o testamento fosse anulado, excluindo politicamente Tibério Gemelo - que morreria assassinado poucos

\footnotetext{
${ }^{827}$ 58.28.3.

${ }^{828}$ Vida de Tibério, 73.2.

${ }^{829}$ Vida de Tibério, 75.1.
} 
meses mais tarde - sob a alegação de que Tibério não estava mais em perfeito juízo quando concebera o documento, o que obtivera aprovação do povo, conquanto os benefícios tenham sido pagos ${ }^{830}$. Curiosamente, Gaio César deixara o Senado perplexo ao pedir a deificação de Tibério, bem como todas as demais honras que o falecido Princeps dedicara a Augusto, embora por fim apenas um funeral oficial tenha sido assegurado, com o elogio proferido pelo próprio novo Imperador seguido de sua cremação, no dia três de abril de 37 d.C. ${ }^{831}$.

${ }^{830}$ Suetônio, Vida de Tibério, 75.3, 76; Suetônio, Calígula, 13, 14.1; Dion Cássio, 58.28.5; EJ 43.

${ }^{831}$ Dion Cássio 59.3.7-8; Suetônio, Calígula, 15.1; EJ 43. 


\section{3 - Entre Roma e Capri: governando o Império}

No decorrer deste texto, elencamos fatores para nossa argumentação de que $\mathrm{o}$ afastamento de Tibério para Capri foi um acontecimento primordial em seu governo, e motivado preponderantemente por fatores políticos: um momento de inflexão que determinou o andamento do restante de seu Principado, cujas causas foram sendo desveladas paulatinamente nos primeiros anos e enquanto estivera em Roma, e cujos desdobramentos influenciaram o destino dos membros da família imperial, boa parte de sua corte, bem como senadores e equestres que se vincularam e buscaram favorecimento a partir do cerne do poder político imperial. Resta-nos agora observamos as principais características de sua administração, questionarmonos sobre em que medida a permanência em Capri afetou ou não seu modo de governar o Império, e como isto se relacionou com o conjunto de seus governados.

De antemão, afirmamos que o afastamento de Tibério para Capri não modificou o comportamento de sua administração provincial. De acordo com Barbara Levick ${ }^{832}$, Tibério agiu com pontualidade e diligência no atendimento às demandas imperiais. Mesmo diante da sequência de intrigas e assassinatos que compuseram seus últimos anos de governo, o Princeps continuou a agir de maneira pragmática quando o assunto dizia respeito a Roma e as províncias; apenas o senso de obrigação para com os seus concidadãos e pares políticos, embora não tenha deixado de existir, tornou-se gradualmente mais protocolar ao longo dos anos, como uma relação entre um patrono e seus clientes, adequada à sua posição soberana.

Contudo, e especialmente em relação à plebe urbana, sua interação teria sido diferente da de Augusto. Suetônio afirma ${ }^{833}$ que Tibério frequentemente dizia para deixar que o odiassem, contanto que 0 respeitassem. Em relação à presença no teatro e nos jogos públicos, Tácito enumera ${ }^{834}$ rumores para o distanciamento do Princeps destes espetáculos:

\footnotetext{
${ }^{832} 1999$, p. 180.

833 Vida de Tibério, 57.2.

${ }^{834}$ Anais, 1.76.3-4; Cf. Dion Cássio, 57.13.1.
} 
aversão a aglomerações, seu temperamento ou receio de comparação com a solicitude de Augusto aos eventos; a indisposição talvez explicasse a redução nos custos dos jogos e apresentações, cortes nos pagamentos dos atores e a limitação dos pares de gladiadores ${ }^{835}$.

Em 14 d.C. foram celebrados os ludi augustales (jogos augustais) em homenagem ao falecido Imperador. Todavia, ocorreu um tumulto decorrente da insatisfação de um dos atores com o pagamento recebido, e os tribunos foram forçados a convocar o Senado para que permitissem aumentar as despesas com remuneração ${ }^{836}$. Tácito e Dion Cássio se complementam ${ }^{837}$ ao informarem que embora não apreciasse os espetáculos, Tibério não considerava sua posição política suficientemente segura a ponto de suprimir uma forma de entretenimento transformada em um direito da plebe por força do hábito; sua presença no teatro durante os primeiros anos de governo derivava principalmente da expectativa de que sua presença agisse como uma influência restritiva contra eventuais perturbações.

Um novo tumulto em 15 d.C. provocou a morte de membros da plebe, soldados e um centurião, bem como o ferimento de um pretoriano enquanto estes últimos tentavam proteger os magistrados e conter a desordem pública. O episódio gerou debate entre os senadores, com proposições que concediam aos pretores a prerrogativa de açoitar os atores. Embora Tibério não tenha permitido a aprovação dessa medida para não infringir os preceitos de Augusto - que uma vez afirmara que os atores deviam ser imunes ao espancamento outros decretos foram aprovados, como a proibição da visita de senadores a pantomimas, que equestres não deveriam se aproximar dos atores em público, que os espetáculos só podiam ser realizados no teatro, e que os pretores poderiam exilar espectadores arruaceiros ${ }^{838}$. E após a morte de Druso Cláudio em 23 d.C., Tibério retomara o assunto perante o Senado, que por fim banira os atores da Itália por todo o resto de seu governo (eles só retornaram por iniciativa de Gaio César), a despeito dos clamores da população ${ }^{839}$.

\footnotetext{
835 Suetônio, Vida de Tibério, 34.1.

836 Tácito, Anais, 1.54.1; Dion Cássio, 56.47.2.

837 Anais, 1.54.2; Dion Cássio, 57.11.5.

838 Tácito, Anais, 1.77.1-4.

839 Tácito, Anais, 4.14; Suetônio, Vida de Tibério, 37.2; Dion Cássio, 57.21.3.
} 
A nosso ver, a necessidade de diminuição de despesas e os sucessivos tumultos contribuíram para Tibério impor grandes restrições aos jogos e ao teatro, mas colateralmente esta política aumentou a impopularidade do Princeps. Em contrapartida, o Princeps foi prestativo no auxílio prestado em tragédias e crises de abastecimento. Em 15 d.C. ocorrera uma enchente no rio Tibre; Tibério nomeou cinco curadores sob a supervisão de L. Arrúntio para o planejamento de desvios e barragens em rios e lagos que convergiam para o Tibre, mas as cidades que seriam afetadas protestaram contra os impactos econômicos e religiosos de tal mudança; diante de tal reação ou da complexidade da intervenção, o Senado por fim decidira que não deveria haver nenhuma interferência na natureza ${ }^{840}$.

Em 19 d.C., Tácito afirma ${ }^{841}$ que, em meio às reclamações da plebe diante dos altos preços do fornecimento de grãos, Tibério fixara o preço a ser pago pelo comprador, enquanto que para o comerciante ele pessoalmente passou a adicionar dois sestércios como complemento a cada medida individual vendida. Veléio Patérculo e Suetônio mencionam ${ }^{842}$ a experiência adquirida anos antes: quando iniciara sua carreira pública aos dezenove anos (23 a.C.), Tibério teria seguido as ordens de Augusto e habilmente controlara as dificuldades para o insuficiente fornecimento de grãos e a escassez de cereal em Roma e em Óstia. Mais ainda, quando a polêmica em torno da lei sumptuária veio novamente à tona em 22 d.C., Tibério determinara quais deveriam ser as preocupações de um Princeps: lidar com a importação de grãos para o abastecimento da Itália, com a sobrevivência do povo romano, e com os bosques e propriedades rurais, caso os recursos das províncias não chegassem à Itália ${ }^{843}$.

Até 23 d.C., Tácito aponta ${ }^{844}$ que a plebe permanecera exaurida pelo fraco abastecimento, embora a culpa não fosse do Princeps: Tibério confrontara à infertilidade das terras e os mares agitados com dinheiro e assiduidade. $O$ problema parece ter continuado nos anos seguintes, pois em 32 d.C., afastado da Capital e cada vez mais alheio à sua própria impopularidade,

\footnotetext{
${ }^{840}$ Tácito, Anais, 1.79-4.

841 Anais, 2.87.

842 2.94.3; Vida de Tibério, 8.

${ }^{843}$ Tácito, Anais, 3.54.4-5. O evento também foi importante por apresentar a evidência de como Tibério definiu o escopo de suas atribuições perante o Senado.

${ }^{844}$ Anais, 4.6.4.
} 
outro incidente referente ao problema de abastecimento resultara em severidade: a plebe se amotinara no teatro durante vários dias consecutivos. Incomodado, Tibério criticara os magistrados e os demais senadores sob o argumento de que eles não haviam refreado a plebe mediante o uso da autoridade oficial, e acrescentou de quais províncias ele estava importando os grãos e o quanto esta importação era maior do que a de Augusto. Por fim, os senadores determinaram a punição da plebe ${ }^{845}$.

Além dos problemas com o entretenimento da plebe e os problemas de abastecimento, as disputas dinásticas também afetaram a popularidade do Princeps, e não sem proveito de seus virtuais opositores. Em 16 d.C. Clemens, travestido como Agripa Póstumo, atraíra uma grande multidão de apoiadores em sua marcha de Óstia para Roma ${ }^{846}$; treze anos mais tarde, os apoiadores de Agripina e Nero encontraram suporte em meio à plebe, sem nos esquecermos da indignação da população diante da ausência de Tibério e Lívia Augusta no funeral de Germânico César em 19 d.C. ${ }^{847}$.

Em Roma ou em Capri, não podemos afirmar que o Princeps não se importava com a opinião de plebe. Em 31 d.C., Tibério recebera duas evidentes indicações de suporte da população à família imperial, quando promovera o filho de Sejano e Gaio César ao sacerdócio. Do mesmo modo, após a eliminação do prefeito da guarda pretoriana, quando a população, além de ter se lançado com violência sobre seu corpo e os monumentos a ele e por ele dedicados, o receio de uma reação da plebe fizera com que Tibério cogitasse a libertação de Druso e sua aclamação como Princeps caso fosse necessário ${ }^{848}$.

Existiram também manifestações em relação à família imperial fora da capital. Na Itália foram relatadas demonstrações de apoio a Clemens, e em 32 d.C. um rumor de que Druso fora visto nas cíclades e na costa da Acáia se espalhara rapidamente até a província da Ásia; um homem posteriormente reconhecido como um dos libertos imperiais havia cooptado companheiros para ludibriar a população local tendo se valido da popularidade do jovem príncipe: o falso Druso teria fugido da prisão e estava buscando apoio das legiões que estiveram sob o comando de Germânico César no Oriente de modo a proceder

\footnotetext{
${ }^{845}$ Tácito, Anais, 6.13.1-2.

${ }^{846}$ Tácito, Anais, 2.40.1; Vida de Tibério 25.1; Dion Cássio 57.16.3.

847 Tácito, Anais, 3.4.5; 5.4.3.

848 Dion Cássio, 58.8.1, 58.11.3, 58.13.1.
} 
com uma invasão da Síria e do Egito. Lá o impostor fora aclamado por uma pequena multidão, e após ter sido descoberto pelo governador Popeio Sabino, dissera ser de fato filho de M. Silano. Em meio à dispersão de seus seguidores, o falso Druso pretendera seguir de barco para a Itália, mas após a notícia ter chegado a Tibério, nada mais se soube sobre ele ou sobre seu fim ${ }^{849}$.

Se a preocupação de Tibério em cumprir as responsabilidades para com a plebe não o tornou popular, sua frugalidade em relação às construções públicas também não gerou uma boa-impressão. É possível que a opinião pública esperasse um programa de construções equivalente ao de Augusto, posto que uma das características de seu programa político constituiu-se do investimento em obras públicas e monumentos. Entretanto, é presumível que Tibério julgasse desnecessário - ou dispendioso - manter ou ampliar esta iniciativa. Nesse sentido, Suetônio afirma ${ }^{850}$ que Tibério não construíra obras dignas de nota, e igualmente deixou as obras do templo a Augusto (dedicada por Tibério logo após a sua morte) e da restauração do anfiteatro de Pompeu inacabadas por vários anos ${ }^{851}$. Em contrapartida, o Princeps terminara as demais obras deixadas incompletas por Augusto, comunidades e outros aristocratas, bem como mantivera os nomes de todos aqueles que haviam iniciado as construções e reparara outras danificadas por incêndio ou pela ação do tempo ${ }^{852}$.

Com estas evidências percebemos - além da pouca preocupação com a exaltação da própria imagem perante a população - a preferência de Tibério ao avivamento e a manutenção da tradição e do prestígio do passado republicano em detrimento da autopromoção, embora os investimentos em obras públicas pudessem ter estimulado a economia, como por exemplo, no emprego de artesãos na Cidade de Roma. De todo modo, frugalidade se confundira com mesquinhez e falta de ambição, aspectos contrastantes à magnificência do governo de Augusto e que teriam afetado a moral da população ${ }^{853}$.

Consequentemente, estes fatores somaram-se aos elementos políticos que inferiram impopularidade ao Princeps; o interesse de Tibério em relação à

\footnotetext{
${ }^{849}$ Tácito, Anais, 5.10.1-3.

${ }^{850}$ Vida de Tibério, 47; Cf. Tácito, Anais, 6.45.1.

${ }^{851}$ Sobre a dedicação do templo de Augusto, cf. Tácito, Anais, 1.10.1.

${ }^{852}$ Dion Cássio, 57.10.1-2; Tácito, Anais, 2.49.1-2.

${ }^{853}$ LEVICK, 1999, p. 95; SEAGER, 2005, p. 117.
} 
preservação do prestígio da aristocracia senatorial e equestre eclipsaram sua iniciativa em relação à plebe. Tal comportamento é compreensível pelo natural desinteresse da própria aristocracia em relação aos outros grupos sociais, embora em última instância o resultado tenha sido politicamente desfavorável para o Princeps, e durante seu período em Capri esta ordem de coisas não se alterou. Durante todo o seu governo, Tibério se preocupou com sua reputação e posteridade perante a aristocracia senatorial e equestre, mas se mostrou nitidamente desdenhoso da opinião dos demais grupos sociais, conquanto não estivesse alheio a estes últimos.

A preferência de Tibério mostrou-se evidente no campo da legislação social, em que seguiu a iniciativa de Augusto. Deste modo, Suetônio afirma ${ }^{854}$ que o Princeps revivera tradicionais costumes ao permitir que matronas de máreputação pudessem ser punidas a partir de um concílio formado pelos seus próprios parentes; punira com exílio muitas que abdicaram do status senatorial e equestre, tornando-se prostitutas para escapar de punições, e jovens aristocratas que desrespeitavam as proibições de aparecerem nas arenas e nos palcos.

Tibério também controlara os preços de carnes, alimentos e restaurantes, embora os episódios que envolveram o reforço na aplicação das leis sumptuárias em 16 e 22 d.C. tenham apresentado um Princeps muito mais preocupado em evitar a banalização das delações do que impor restrições ao comportamento de consumo da aristocracia ${ }^{855}$. Em 20 d.C. o Senado encaminhou um pedido de atenuação da Leges Papia Poppaea introduzida por Augusto; na medida em que a lei se mostrou infrutífera em aumentar a natalidade dentro da aristocracia, bem como se configurou enquanto foco para incitar a ação dos acusadores, Tibério constituíra uma comissão de quinze senadores para analisar individualmente os casos e impedir abusos ${ }^{856}$.

Boa parte da reação acrimoniosa da plebe relacionou-se às disputas dinásticas dentro da família imperial, entre a "soberba" (superbia) de Tibério e da família Cláudia ${ }^{857}$, e a afabilidade e popularidade pretendida e apreciada pelo núcleo familiar de Germânico César e Agripina. O distanciamento de

\footnotetext{
${ }^{854}$ Vida de Tibério, 35.1-2; Cf. Tácito, Anais, 2.35.

${ }^{855}$ Suetônio, Vida de Tibério, 34.1; Tácito, Anais, 2.33, 3.52.5; Dion Cássio, 57.13.3.

${ }^{856}$ Tácito, Anais, 3.25.1, 3.28.4.

${ }^{857}$ Idem, 1.4.2, 1.10.7.
} 
Tibério e sua mãe Lívia face aos acontecimentos decorrentes da morte de Germânico César foram inevitavelmente relacionados como cumplicidade no crime, a despeito da condenação dos autores e das posteriores homenagens decretadas pela própria família imperial e o Senado.

Mais ainda, com as mortes de Nero, Druso e finalmente Agripina, o que ainda parecia suspeito passou a ser considerado como certeza pela opinião pública. Neste contexto, o afastamento de Tibério somente contribuiu para ampliar o ressentimento da população perante um Princeps que, embora responsável pelo seu dever público, claramente demonstrava que não desejava ser perturbado pela plebe. $O$ distanciamento contribuiu para incitar o rumor e a imaginação de críticos e detratores, estórias de um cotidiano de devassidão na nova corte fora da Cidade de Roma.

A frustração perante sua incapacidade de promover e contar com a autonomia senatorial, o agravamento desta situação ao retirar-se de Roma, a pouca preocupação em relação à opinião da plebe, e o desenrolar das intrigas dinásticas contribuíram para potencializar o descontentamento dos opositores ao regime político e à sua ascensão três décadas antes, ainda com Augusto vivo ${ }^{858}$. Consequentemente Gaio César, além de ter sido visto como um herdeiro da popularidade de sua família, também foi visto (não unanimemente) como alento a um período sombrio, ou um sobrevivente em meio à sistemática eliminação de sua família. Contudo, o desejo da plebe em lançar o corpo de Tibério no Rio Tibre não se originou somente da intenção de demonstrar adesão ao novo Princeps, mas da insatisfação com o comportamento do falecido Imperador, conquanto a relação parental de Gaio César a Tibério e sua proeminente posição no testamento de Tibério pode ter arrefecido os ânimos mais exaltados da população, e até mesmo de alguns senadores.

Em outros aspectos, o governo de Tibério foi um período de relativa estabilidade militar e paz nos arredores do Império. A maior parte das legiões concentrou-se nas regiões de fronteira: três no llírico, duas na Dalmácia, e mais duas na Moésia; oito legiões concentraram-se às margens do Rio Reno, para proteger a fronteira dos germanos e conter revoltas na Gália. Paralelamente, a Hispânia - tumultuada durante o governo de Augusto - pôde

${ }^{858}$ LEVICK, 1999, p. 96. 
contar com três legiões, a província da África com uma, o Egito mais duas, e finalmente a Síria possuiu quatro legiões estacionadas, com a finalidade de policiamento superior à de salvaguarda contra os partas, que geralmente não se manifestavam quando não provocados. Por último, a Itália contou com três coortes urbanas, as nove coortes da guarda pretoriana, e duas importantes bases navais em Ravena e Miseno - a terceira ficava na Gália ${ }^{859}$.

Tibério também se manteve leal à instrução de Augusto para não expandir o Império além de suas fronteiras, e interveio somente quando existiu algum risco à segurança das províncias. Deste modo, as principais mudanças ocorreram no Oriente, onde os reis-clientes da Capadócia, Comagênia e Silícia faleceram: mediante a ação dos legados, a primeira, cujo rei Arquelau morrera em Roma após ter sido convocado pelo Senado sob a suspeita de traição, e a Comagênia foram incorporadas ao Império, enquanto que a Cilícia tornara-se parte da província da Síria. Enquanto procônsul no Oriente, Germânico César possibilitara a ascensão de Artabano III ao trono parta, enquanto Artaxias III ficara com a Armênia ${ }^{860}$.

Todavia, em 34 d.C. este rei parta tentou intervir na sucessão do trono armeno, o que teria provocado uma guerra com Roma não obstante seu encontro com L. Vitélio (legado da Síria entre 35 e 37 d.C.) tenha por fim feito com que ele concordasse com a ascensão de Mitrídates na Armênia ${ }^{861}$. Igualmente, L. Vitélio foi responsável por refrear os equívocos do governador Pôncio Pilatos na Judéia, trazendo-o a Roma para julgamento após o massacre de comunidades samaritanas na região; acordos foram feitos com a comunidade judaica para que seus sacerdotes pudessem usar novamente suas vestimentas religiosas, bem como Roma aceitara desviar suas tropas para que os estandartes das legiões não precisassem ser fixados em solo judeu, o que para eles constituía uma profanação ${ }^{862}$.

No Ocidente e ao norte ocorreram poucas transformações, especialmente após Tibério ter proibido que Germânico César continuasse suas investidas contra os germanos para além do rio Elba em 16 d.C. Anos

\footnotetext{
${ }^{859}$ SEAGER, 2005, p. 138-9.

${ }^{860}$ Cf. Tácito, Anais, 2.1-4,42-3; Suetônio, Vida de Tibério, 8, 37.4; Dion Cássio, 57.17.3. Res Gestae Divi Augusti, 32.2, 33.

${ }^{861}$ Tácito, Anais, 6.31-37, 41-44; Suetônio, Vida de Tibério, 41, 66, Dion Cássio, 58.26.1.

${ }^{862}$ SCULLARD, 2011, p. 235.
} 
mais tarde, em 28 d.C., quando os frísios se revoltaram contra os excessos na tributação local, o Princeps não tentara submetê-los à força. Na região do Rio Danúbio, Tibério fixou tropas de auxiliares pertencentes aos suevos e marcomânos sob o comando de um general nativo chamado Vânio como maneira de evitar invasores. As províncias da Acáia, Macedônia e Moésia foram centralizadas ao comando de Popeio Sabino (15 a 35 d.C.), arranjo que perdurara até 44 d.C.

Por fim, três conflitos de pequenas proporções ocorreram durante 0 governo, nas regiões da Trácia, Gália e África ${ }^{863}$. Na primeira destas, anteriormente dividida por Augusto entre dois reis, Cótis VIII e Rescúporis II, este último matara seu consorte em 19 d.C., tendo levado Roma a intervir na região. Após a deposição do sobrevivente, a região foi confiada a Roemetalces II, embora sublevações tenham ocorrido novamente em 21 e 25 d.C., em que por fim atuara como coregente da Trácia junto de Triphena, sendo por fim sucedido em 38 d.C. por Roemetalces III e Pitodóris II. Já a região da Gália vivenciara uma sublevação em 21 d.C., organizada por dois proeminentes provinciais, Júnio Floro e Júlio Sacrovir.

A principal causa parece ter se originado dos gastos excessivos provenientes do suporte às campanhas de Germânico César contra os germanos e das exações de comerciantes romanos. Contudo, o druidismo também parece ter sido um foco de conflito, pois Augusto e Tibério temiam os elementos antirromanos em certos aspectos do culto e eram contrários à prática de sacrifícios humanos. Todavia, a revolta foi rapidamente esmagada pelas legiões estacionadas ao norte e comandadas por $\mathrm{C}$. Sílio, conquanto três anos mais tarde este último tenha sido condenado por extorsão. Na província da África, algumas comunidades se amotinaram sob o comando do ex-general e desertor númida Tacfarinas, onde promoveram um reide ao sul em 17 d.C. Uma vez que os legados enviados pelo Senado não conseguiram neutralizar a rebelião, Júnio Bleso acabara sendo escolhido para coordenar uma investida em 20 d.C.; e após algumas vitórias que the valeram a aclamação de imperator, ele fora sucedido por P. Cornélio Dolabela, que finalmente capturara

\footnotetext{
${ }^{863}$ Para cada revolta, conferir respectivamente: Tácito, Anais, 2.64-67, 3.38, 4.46-51, Suetônio, Vida de Tibério, 37.4, Veléio Patérculo 2.129.1; Tácito, Anais, 3.40-7, Veléio Patérculo, 2.129.2; Tácito, Anais, 3.20-1, 3.32-5, 3.47, 3.69, 3.73-4, 4.23-6, Suetônio, Vida de Tibério, 32.1.
} 
e assassinara Tacfarinas em 24 d.C.. Desde então, a província se restabelecera e continuara a ser um dos grandes fornecedores de provisões do Império ${ }^{864}$.

Estas perturbações não obscureceram o fato de que, embora não tenha havido nenhum crescimento extraordinário, as províncias imperiais continuaram vivenciando um período de estabilidade e relativa prosperidade durante 0 governo de Tibério, que adotou uma política semelhante às últimas duas décadas do Principado de Augusto: pelo menos até a morte de Druso César em 23 d.C., o Princeps confiara nos membros da família imperial, e ao contrário do longo período em que servira Augusto com este propósito, Tibério não visitou nenhuma outra província a partir de sua ascensão, e muito menos após ter se afastado para Capri.

Isto não significara que o Princeps não tenha interferido nas províncias; provavelmente a magnitude do Império, conquanto este argumento tenha sido visto com reticência por parte da tradição literária, e a necessidade de se olhar toda a administração em perspectiva tenham sido razões genuínas para sua permanência na capital. A situação não parece ter se alterado após seu afastamento para Capri: uma vez que sua posição política foi uma adição de prerrogativas e um amalgama de funções administrativas pré-existentes, sua presença não era necessária para que a administração imperial funcionasse.

Augusto também permanecera vários anos entre uma província e outra, enquanto contava com a ajuda de seus consortes e legados para coordenar e manter a estabilidade imperial. Em Capri, Tibério manteve sua influência sobre os assuntos públicos (especialmente pelo suporte de Sejano e Macro). Com sua nova corte instalada fora de Roma, e o centro decisório do poder para lá transferido, as questões particularmente importantes continuaram sob sua atenção. E em contrapartida, o afastamento para Capri deve ter aliviado o Princeps dos cerimoniais cotidianos, e as formalidades do comparecimento ao Senado ${ }^{865}$, para além dos prováveis aborrecimentos que já mencionamos durante a tese.

Mais ainda, possivelmente Tibério esteve mais interessado em explorar as províncias para subsidiar o abastecimento da ltália do que incentivar o

\footnotetext{
${ }^{864}$ SEAGER, 2005, p. 139-144; SCULLARD, 2011, p. 235-6.

${ }^{865}$ ALSTON, 1997, p. 38.
} 
desenvolvimento social e econômico nas províncias de modo que estas pudessem se equivaler à península ${ }^{866}$. Sobre este quesito, Dion Cássio e Suetônio expõem ${ }^{867}$ a preocupação de Tibério em não permitir que os governadores provinciais aplicassem tributos onerosos, mencionando a reprimenda do Princeps a Emílio Recto, prefeito do Egito em 15 d.C., que por ter percebido que a arrecadação havia sido maior do que o estipulado, dissera que queria suas ovelhas tosquiadas, mas não raspadas. Todavia, isto não impedira que vários governadores tivessem sido condenados por extorsão, mesmo que algumas condenações tenham sido associadas ao crime de traição.

Assim ocorrera com o pretor Grânio Marcelo em 15 d.C., embora sua absolvição do crime de traição não tenha impedido que este continuasse a ser investigado por extorsão na Bitínia, cujo veredito é ignorado ${ }^{868}$; Césio Cordo fora condenado em 22 d.C. por extorsão em Creta e Cirene ${ }^{869}$; Víbio Sereno, governador da Hispânia Ulterior, fora condenado ao exílio por uso arbitrário da força (vis publica) contra romanos no ano de 23 d.C. ${ }^{870}$; Caio Silano, governador da província da Ásia, também foi condenado por extorsão no mesmo ano, e igualmente o procurador C. Lucílio Capito, condenado e exilado por ter cooptado parte das tropas estacionadas para coletar tributos; e embora esta última prática não fosse incomum durante a República, Tibério repudiara a prática por contrariar os limites da autoridade imperial e como uma provocação contra suas ordens ${ }^{871}$.

Por último, a mencionada revolta na Gália tivera como uma de suas causas o excesso de tributos cobrados pela administração provincial. Igualmente, os frísios se revoltaram pela bancarrota causada por um tratado feito com os romanos em troca de peles de animais, embora a perturbação não tenha requerido uma ofensiva militar romana ${ }^{872}$. Mas a principal peculiaridade da administração provincial de Tibério foi o hábito de deixar governadores provinciais no cargo durante vários anos a fio. Apontado por Augusto como

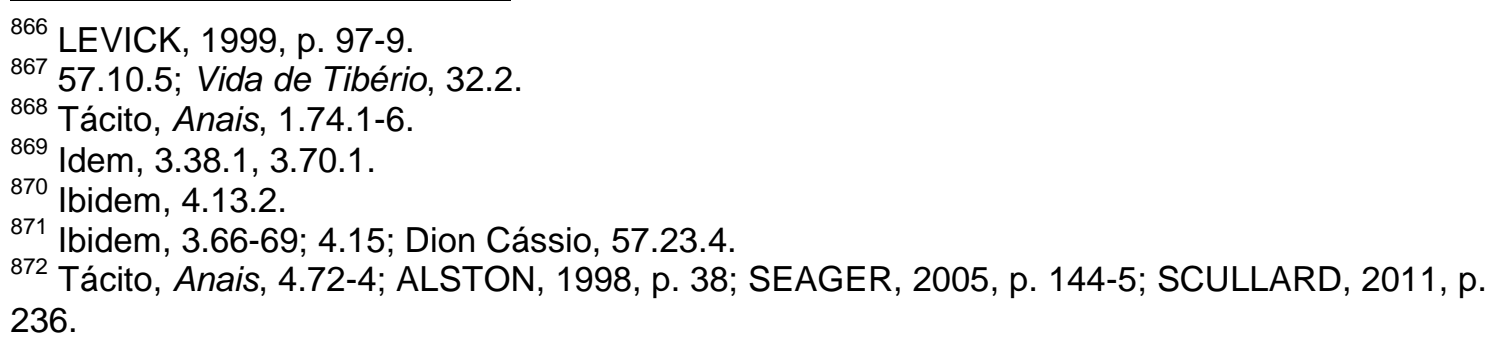


governador da província da Moésia em 12 d.C., Popeio Sabino teve a posse do cargo estendida três anos depois, tendo sido responsabilizado também pela administração da Acáia e Macedônia até 35 d.C.. Tácito afirma ${ }^{873}$ que a razão desta prática teria sido o fato de que Tibério não gostava de tomar decisões e não via razão para mudanças quando os arranjos preexistentes the pareciam satisfatórios. A nosso ver, este modo de agir era essencialmente pragmático, sendo bastante razoável que homens competentes e cujas ambições não Ihe parecessem ameaçadoras permanecessem o máximo possível nos mesmos postos políticos.

Ainda no escopo dos expedientes administrativos, alguns exemplos de apoio financeiro também são mencionados. Em 15 d.C. as províncias da Acáia e da Macedônia reclamaram dos custos das tributações, e consequentemente um decreto foi aprovado em que a supervisão da tributação passava das mãos do Senado para as do Princeps ${ }^{874}$. Embora não se saiba como isto se reverteu em alívio para as regiões solicitantes, provavelmente a união da administração destas à supervisão do governador da Moésia pode ter resultados em menores gastos.

Em 17 d.C., um terremoto destruiu doze cidades na província da Ásia, tendo causado estragos na região da Sicília e na cidade de Régio. A cidade de Sardis, a mais atingida com o tremor de terra, recebera uma doação de um milhão de sestércios, e a tributação de todas as cidades fora suspensa durante os cinco anos seguintes; o ex-pretor M. Ateio foi escolhido para inspecionar os danos e supervisionar os trabalhos de restauração, e as cidades exaltaram Tibério como fundador, erigiram uma estátua na Cidade de Roma, e moedas foram cunhadas no mesmo ano exaltando sua liberalidade (liberalitas) ${ }^{875}$.

Em 23 d.C. outro terremoto - de menor gravidade - atingiu a cidade de Aegio, na Acáia, e Cibira, na Ásia, que tiveram suas tributações suspensas por três anos ${ }^{876}$. Em 36 d.C., um incêndio atingiu parte da Cidade de Roma, nas imediações do monte Aventino. Tibério concedera um milhão de sestércios para a recuperação das residências destruídas, de modo que a supervisão dos

\footnotetext{
${ }^{873}$ Anais, 1.80.1-3, 6.39.3.

874 Tácito, Anais, 1.76.2

875 Tácito, Anais, 2.47; Suetônio, Vida de Tibério, 48.2, Dion Cássio, 57.17.7, Veléio Patérculo, 2.126.4; Cf. ILS 156 = EJ 50, EJ 49 .

${ }^{876}$ Tácito, Anais, 4.13.1.
} 
danos individuais foi avaliada por uma comissão constituída de seus quatro genros - Cneio Domício, Cássio Longino, M. Vinício e Rubélio Blando - bem como P. Petrônio, designado pelo cônsul. Honras teriam sido escolhidas e concedidas ao Imperador, embora não se saiba se ele as aceitou ${ }^{877}$.

No tocante à administração financeira imperial, a crise de circulação monetária de 33 d.C. parece ter sido o principal acontecimento administrativo do governo de Tibério. Tácito, Dion Cássio e Suetônio nos informam sobre detalhes do ocorrido. $O$ primeiro autor afirma ${ }^{878}$ que muitos acusadores teriam se lançado contra aqueles que estavam enriquecendo mediante a usura, resultado da negligência no cumprimento de medidas propostas em lei por Júlio César e referentes ao limite do crédito e das possessões de terra na Itália. A prática da usura e as consequentes contendas desta prática eram costumeiras na Cidade de Roma, e já constava na Lei das Doze Tábuas que ninguém poderia realizar empréstimos com taxas de juros superiores a um por cento; um complemento realizado por um tribuno da plebe posteriormente reduzira as taxas para meio por cento, e por fim as mesmas acabaram sendo abolidas.

A veracidade das informações apresentadas por Tácito sobre o histórico da evolução das taxas de juros é altamente controversa ${ }^{879}$. A preocupação do autor é demonstrar como a infração da lei que coibia a prática da usura tornarase mais um pretexto para a ação dos acusadores, a conduta dos senadores perante estes eventos e a relação dos mesmos com Tibério; pudemos observar outros exemplos durante nosso trabalho. Desta forma, este autor complementa $^{880}$ que durante a ocasião, a questão havia recaído sobre a responsabilidade do pretor Graco que, preocupado com a quantidade de aristocratas envolvidos, encaminhou o problema ao Senado. Amedrontados, estes buscaram imediato perdão ao Princeps, e Tibério concedera então um prazo de dezoito meses para que todos colocassem suas pendências em ordem.

Contudo, o que imediatamente ocorrera fora uma escassez de moeda corrente; todos os credores convocaram simultaneamente seus devedores a quitarem integralmente suas dívidas, e a condenação massiva dos demais -

\footnotetext{
${ }^{877}$ Idem, 6.45.1-2.

878 Ibidem, 6.16.1-2.

${ }^{879}$ Cf. WOODMAN, 2004, p. 174, nota 57.

${ }^{880}$ Tácito, Anais, 6.45.3.
} 
com a confiscação e leilão de seus bens - fizera com que o numerário ficasse retido ao fisco ou ao erário do Princeps ${ }^{881}$. Sobre esta passagem, Cosmo Rodewald ${ }^{882}$ afirma que a interpretação do contexto nos leva a crer que Tácito se referiu às condenações de uma maneira geral, e não em decorrência dos empréstimos. Igualmente, se o numerário proveniente do leilão dos bens confiscados ficou em maior ou menor medida restrita ao tesouro imperial ou privado do Imperador, em verdade o que interessa de fato é que toda a administração imperial era, desde Augusto, em última instância controlada pelo próprio Princeps.

Em resposta ao problema, Tácito afirma que ${ }^{883}$ o Senado determinara que dois terços de todas as dívidas fossem reembolsados de uma só vez, e que o dinheiro recuperado fosse investido em terras italianas, paliativo que não satisfizera nenhum dos lados envolvidos: os credores exigiram dos devedores ressarcimento integral, ao passo que estes últimos temiam perder a possibilidade de contrair futuros empréstimos caso usufruíssem das vantagens fornecidas pelo decreto.

E na medida em que, primeiramente, iniciou-se uma corrida para a contração de novos empréstimos para sanar dívidas, os usurários (ou emprestadores, i.e. faeneratores) investiram todo o seu dinheiro na compra de terras. Consequentemente, à abundância de terras seguiu-se sua desvalorização, e quanto mais endividado era o devedor, maior a dificuldade em vender sua propriedade, e assim vários destes tiveram suas fortunas arruinadas $^{884}$ (inaptos a pagarem suas dívidas no prazo estabelecido pelos credores).

A ruína trouxe consigo o declínio do status e prestígio desses homens. Diante deste panorama, Dion Cássio afirma ${ }^{885}$ que Nerva (proeminente senador e associado de Tibério) recorreu ao suicídio, pois o reforço da lei de César ao mesmo tempo privou a contração de empréstimos, fez com que a quitação das dívidas tornasse-se impraticável. Uma postura mais moderada teria, por conseguinte, se materializado no auxílio de Tibério, que distribuíra

\footnotetext{
${ }^{881}$ Idem, 6.17.1.

882 1976, p. 76, nota 03.

883 Anais, 6.17.2-3; Suetônio, Vida de Tibério, 48.1.

884 Tácito, Anais, 6.17.3

885 58.21.4.
} 
cem milhões de sestércios disponíveis no erário para a concessão de empréstimos isentos de juros durante os três anos seguintes, com a condição de que os devedores restituíssem no final o dobro da quantia sob a forma de propriedades fundiárias para o Estado ${ }^{886}$. Suetônio afirma ${ }^{887}$ que esta ação fora uma demonstração pública de munificência, uma vez que as medidas anteriores falharam em solucionar o problema. O crédito por fim fora restabelecido, bem como a prática de empréstimo pelos usurários, e Tibério teria ainda ordenado que os principais acusadores fossem executados no mesmo dia ${ }^{888}$.

Nenhum dos três autores mencionados fornece maiores explicações sobre os fatores que levaram a esta crise financeira, e os relatos são enigmáticos na medida em que pressupõe do leitor um conhecimento sobre este assunto que dispensa grandes esclarecimentos, principalmente sobre a lei de restrições sobre as taxas de juros impostas durante o período republicano. Não sabemos também quais eram os objetivos dos acusadores neste caso. $O$ que parece plausível é o fato de que, uma vez que Tibério compreendeu que a iniciativa do pretor Semprônio Graco era a de restabelecer parâmetros de conduta senatorial equivalentes aos preceitos republicanos (algo compreensível no âmbito da prática política de Augusto e seu sucessor), o Princeps inicialmente não vira grandes problemas nessa ação.

Contudo, a aplicação da lei, assim como fora o caso da aplicação da lei de traição, consequentemente trouxe a reboque a perniciosa prática indiscriminada da delação. A nosso ver, esta é a alusão que Tácito quis fazer ao narrar este caso, portando a insinuação de que era do interesse do Imperador que os senadores fossem condenados, e seus bens confiscados. Entretanto, o inconveniente resultado disso pode justificar a alusão feita por Dion Cássio ao suicídio de Nerva; e o Princeps, a despeito de seu irremediável distanciamento no que tangeu às interações políticas com a maior parte dos membros da aristocracia, provavelmente exercera a munificência (se o dinheiro veio de sua riqueza pessoal ou não, não saberemos) por não desejar o prejuízo

\footnotetext{
${ }^{886}$ Dion Cássio, 58.21.5; Tácito, Anais, 6.17.3.

887 Vida de Tibério, 48.1.

888 Tácito, Anais, 6.17.3-4; Dion Cássio, 58.21.5.
} 
da posição e prestígio de seus concidadãos. Neste quesito, sua conduta não desviou dos anos em que permanecera em Roma.

Mas a grande polêmica presente na historiografia recente em relação à crise financeira de 33 d.C. consistiu na busca de explicações para as causas ou origens deste problema. Cosmo Rodewald (1976) questionou os principais postulados de Tenney $\mathrm{Frank}^{889}$ sobre este assunto, que para o último representou a evidência de uma contração da circulação de moeda corrente na Itália, consequência da tendência de Tibério em acumular metais preciosos e moedas ao invés de estimular a cunhagem e a circulação, como fizera seu antecessor.

Os argumentos de Frank foram embasados em uma análise comparativa do numerário encontrado nas escavações e atribuídos aos períodos entre Augusto e Cláudio, bem como na observação de uma iniciativa de Tibério de, logo após 33 d.C., confiscar minas de ouro e prata para o fiscus. Isto se deu pela menção de Tácito ${ }^{890}$ à condenação por incesto de Sexto Mário, o mais rico provincial da Hispânia, ter na verdade sido um pretexto para a confiscação (e a insinuação de que Tibério se apropriara pessoalmente das minas). Igualmente, Suetônio afirma que durante os últimos do governo deste Princeps, muitos indivíduos e comunidades teriam sido privados de seus direitos com relação às minas e rendimentos ${ }^{891}$.

De acordo com Rodewald ${ }^{892}$, a análise das evidências sobre a crise careceu de uma análise mais acurada do contexto econômico dos governos de Augusto e Tibério. Nesse sentido, os quarenta e três anos de intervalo entre 10 a.C. e 33 d.C. teriam significado não uma retração da cunhagem de novas moedas pelos Imperadores, mas sim um estímulo na circulação de antigas moedas romanas, ou mesmo de moedas estrangeiras. Embora a cunhagem de moedas imperiais possuísse o apelo de difusão de valores e ideais para a legitimação da soberania do Princeps e da família imperial (e uma grande cunhagem é evidente entre meados de 20 até 12 a.C.), a ampla circulação teria sido também uma consequência dos custos das alianças feitas por Augusto, do

\footnotetext{
889 1935, p. 340-1.

890 Tácito, Anais, 6.19.2. Cf. Dion Cássio, 58.22.2.

891 Vida de Tibério, 49.1-2.

892 1976, p.4-5.
} 
pagamento de suas tropas e do estímulo para consolidar pactos políticos com outras comunidades ao redor do Império.

Possivelmente os anos posteriores tivessem demandado uma menor necessidade em reforçar mediante a cunhagem os vínculos dessa noção de consenso, mas é plausível que a grande vantagem no reuso de moedas antigas teria sido a redução nos altos custos de fundição destas últimas para a confecção de novas moedas imperiais, uma vez que as mesmas moedas eram amplamente utilizadas e reconhecidas dentro do mundo romano.

Igualmente, tanto a cunhagem de novas moedas quanto a continuidade na circulação de moedas antigas (inclusive do Oriente helenístico, a despeito da baixa qualidade de suas moedas, como as do Egito Ptolomaico) não teria representado uma queda no lastro ou aumento significativo dos preços em decorrência da ampliação da circulação para as várias províncias. Portanto, a despeito da relativa diminuição na cunhagem a partir de 10 a.C., este fato não representou necessariamente uma estagnação ou retração da circulação monetária desde então ${ }^{893}$.

Esta análise contextual serviu para Rodewald contestar a tese de Frank de que Tibério teria sido responsável por uma perniciosa contração na circulação monetária durante seu governo ${ }^{894}$. Deste modo, a despeito da sugestão de Frank que considerou que Tibério, ou por frugalidade ou avareza, teria conseguido fazer com que os cem milhões herdados de Augusto tornassem-se dois bilhões e setecentos milhos de sestércios quando Gaio César assumiu o poder (de acordo com estimativas deduzidas de dois trechos sobre o assunto 'herança' presentes em Suetônio ${ }^{895}$ ), esta representação da "mordomia" (stewardship) de Tibério seria inconsistente ${ }^{896}$.

Tem-se a impressão de que Augusto adquirira popularidade por sua munificência por ter tido mais dinheiro para gastar do que Tibério, que em contrapartida tornou-se impopular pela avareza em decorrência de possuir menos dinheiro e ter sido consciente deste fato. Por outro lado, é presumível que tenha havido uma diminuição na quantidade de ouro e prata isenta dos

\footnotetext{
${ }^{893}$ RODEWALD, 1976, p. 6-11.

${ }^{894}$ 1976, p. 11.

${ }^{895}$ Vida de Augusto, 101; Calígula, 37.

${ }^{896}$ FRANK, T. An Economic Survey of Ancient Rome, Vol. 5, p. 37 apud RODEWALD, 1976, p.
} 11. 
custos de cunhagem durante o governo de Tibério, uma vez que menos riquezas advieram da conquista militar, confiscação, ou mesmo de doações ao Imperador.

Acompanhado da evidência numismática, Rodewald conclui ${ }^{897}$ que, distante do entesouramento, Tibério deve ter sido consciente da cautela que deveria ter quanto aos gastos imperiais, e utilizado o dinheiro na medida do possível - o que não o isentou da impopularidade adquirida. Igualmente, ao contrário de Augusto, teria restringido a difusão das virtudes imperiais majoritariamente à Clementia e Concordia, bem como sua preocupação em exaltar suas virtudes mediante a cunhagem parece ter sido bem menos prolifica do que em Augusto.

Consequentemente, podemos observar que as evidencias não apontaram substancialmente para uma crise de circulação monetária durante o governo de Tibério. Rodewald afirma ${ }^{898}$ que não há uma relação intrínseca entre acusações e condenações como sendo decorrentes do aumento no oferecimento de empréstimos, e tampouco de que as (prováveis) altas taxas de juros vinculadas a estes empréstimos tenham sido uma evidência da baixa quantidade de moeda ou crédito em circulação.

De modo semelhante, não há evidencias decisivas que comprovem a diminuição na circulação de moeda durante o governo de Tibério como resultado de uma diminuição na cunhagem imperial; a despeito dos propósitos políticos, moedas antigas tinham a mesma serventia prática das moedas novas. A confiscação de minas no Império ou dos bens dos acusados também não representa um conjunto de evidências concretas de falta de moeda no tesouro imperial: o controle direto do Princeps sobre a administração não necessariamente ampliaria 0 fornecimento de metais preciosos; reconhecidamente, os funcionários imperiais poderiam tomar posse do metal refinado caso realmente tivesse havido um esgotamento de matéria-prima para cunhagem, e provavelmente sem a necessidade de confiscação.

Também é complicado afirmar que o governo de Tibério vivenciara dificuldades em seus gastos ou que o Princeps estava pessoalmente determinado a não gastar nada do tesouro imperial: o Imperador rapidamente 
lançou mão de cem milhões de sestércios diante do agravamento da situação financeira senatorial e, em 37 d.C., novamente concedeu cem milhões de sestércios para auxiliar os prejuízos decorrentes do incêndio em Roma ${ }^{899}$. É provável que, em decorrência destas duas ocasiões, mais dinheiro tenha circulado em Roma e na Itália, mas é notório como nenhum indício de promoção política tenha aparecido sob a forma de cunhagem de moedas nesse período; a carência de evidencias materiais nesse caso somente atesta a pouca preocupação - sobretudo nos últimos anos do governo de Tibério - com sua popularidade perante a população urbana e imperial ${ }^{900}$.

${ }^{899}$ Tácito, Anais, 6.45.3.

${ }^{900}$ RODEWALD, 1976, p. 16-7. Cf. LEVICK, 1999, p. 104. 


\section{CONCLUSÃO}

De acordo com Robin Seager ${ }^{901}$, os vinte e dois anos de governo de Tibério foram simultaneamente um período de transição e de consolidação. Tanto o governo de Augusto quanto o de seu sucessor foram, sobretudo, processos de experimentação política. Nesse período, Augusto e Tibério se mostraram conscienciosos da necessidade de exaltar o Senado e promover homens que, como ele e sua própria linhagem, pertenceram à nobreza republicana, mas também fazer o mesmo por membros oriundos das novas famílias consulares que ascenderam anteriormente e durante o governo de seu antecessor, mas sem macular o novo sistema político aos quais ambos deviam sua própria posição de poder.

Isso significa dizer que Augusto, e por consequência Tibério e seus apoiadores buscaram uma manutenção possível dos valores e tradições que representavam a República, a despeito das inerentes transformações nos significados de suas principais ideias durante o início do Principado. Assim como na res publica, o populi romani estava indistintamente vinculado ao cotidiano político, conquanto saibamos os limites da participação popular e a perenidade do controle nas mãos da aristocracia, e mais precisamente de algumas casas senatoriais que se perpetuaram, contraíram novas alianças ou abriram espaço para novas famílias oriundas inicialmente da Itália, e posteriormente do restante das províncias durante o Principado. Quanto à ordem equestre, esta continuou em elevação mediante a participação no exército e na administração imperial, embora o principal destaque entre esses indivíduos possa ser sumarizado pela iniciativa individual de Sejano e Macro, prefeitos da guarda pretoriana.

Em outros termos, pensar no impacto do afastamento de Tibério para Capri significa pensar no conflito trazido pela ausência da figura central no quadro das interações políticas interpessoais da Cidade de Roma, sob o nosso enfoque primordialmente indivíduos da aristocracia senatorial e equestre da capital do Império. Essas interações constituíram, assim como durante a

901 2005, p. 209. 
República, no amalgama do Principado durante o período dos Césares JúlioClaudianos, cujas leis, tradições e valores não se dissociaram das noções de status, prestígio e riqueza consonantes com a própria estrutura política da sociedade romana.

Teria sido parte da modestia de Tibério, a consciência de suas limitações, e a compreensão de tanto ele quanto seus pares eram efêmeros diante de uma res publica eterna, que justificou a importância da deificação de Augusto. No entanto, o vínculo com seu antepassado serviu como elemento de garantia da permanência do Principado, do conjunto de rearranjos e adaptações protagonizados anteriormente pelo falecido Imperador, consortes e apoiadores durante quase cinco décadas, condição que pode assim ter implicado em duas das principais iniciativas políticas de Tibério, evidentes desde o início de seu governo: a manutenção dos preceitos políticos de seu predecessor - tornando mandatório o que fora até então aconselhável - e a diminuição de seu status político perante Augusto e o Senado ${ }^{902}$.

Entretanto, a própria ambivalência deste novo sistema político em sua configuração inicial, o crescente temor por segurança pessoal, e a prontidão de certos indivíduos para explorar a sua desconfiança configuraram-se como obstáculos à participação e promoção de parte da aristocracia, e paradoxalmente a tentativa de manutenção da tradição caminhou ao lado do esvaziamento de interesses efetivos pelos negócios públicos no cotidiano da capital do Império. Esta idiossincrasia contribuiu para reduzir a participação política da aristocracia e manter a tendência à autocracia que se verificará a partir de Gaio César. Durante seus anos em Roma, Tibério tentara incutir no Senado (embora não tenha considerado que a instituição, acima de tudo, era composta de interesses individuais) a aceitação de uma ampla gama de responsabilidades, não obstante grande parte dessa iniciativa já tivesse se perdido no governo de seu antecessor.

Durante o primeiro capítulo apresentamos panoramicamente os principais aspectos do governo de Augusto, sem os quais julgamos que se tornaria muito mais difícil compreender o Principado de Tibério. Os anos de guerra civil entre os generais republicanos culminaram com o triunfo de

902 LEVICK, 1999, p. 178-9. 
Augusto na batalha do Áccio em 31 a.C. Este evento simbolizou um marco pelo qual o herdeiro de Júlio César promoveu, sobretudo a partir 27 a.C., o formal restabelecimento da República ao Senado e o povo romano, e o cumprimento de sua responsabilidade como triúnviro.

O quão isto foi um estratagema ou não continua a alimentar debates historiográficos que jamais se esgotariam nesta tese. De fato, ao tornar-se Princeps, Augusto ascendeu como ao posto de mandatário da coletividade romana, carregando consigo os interesses de novos agentes políticos que passaram a ter maior representatividade a partir do último século da República. Há uma evidente ruptura com o passado (algo bem compreendido pelos historiógrafos da aristocracia senatorial posterior), conquanto o desejo de considerar as cinco décadas do governo do primeiro Princeps como um continuum engendrado previamente, e o desejo de impor uma denominação a este tempo tenham sido anacronismos dos quais nem mesmo os leitores mais próximos deste tempo puderam escapar: este processo foi gradual, experimental, e provavelmente contou com o auxílio de vários apoiadores, principalmente uma conjunção de senadores e equestres pertencentes a famílias italianas que até então não tinham tido a possibilidade de ascender na carreira pública.

Os anos que se seguiram à primeira década do governo de Augusto representaram a confirmação deste processo de concentração dos poderes e magistraturas nas mãos de um líder máximo. Claro que isto não ocorreu sem percalços: as fronteiras continuaram guarnecidas perante ameaças germânicas, os reinos vizinhos do oriente continuaram exigindo atenção do Princeps e de seus legados, e na Cidade de Roma, demandas de infraestrutura e abastecimento necessitaram de uma atenção especial do Imperador e de seus subordinados, e conspirações emanaram de círculos extremamente próximos à sua pessoa e à família imperial.

Entretanto, fora no Senado e na ordem equestre que Augusto buscou os magistrados e oficiais para a administração do Império: a carreira senatorial continuou a ser foco de disputas entre os membros da aristocracia, não obstante tenha adquirido uma função cada vez mais judicial; a perda da efervescência republicana pelo debate pública foi substituída pelo aumento na importância da patronagem imperial: cotidianamente, o ambiente do palácio e 
da corte imperial tornou-se mais importante do que a praça pública e a câmara senatorial, não obstante oficialmente o Senado jamais tivera o seu prestígio institucional questionado.

A corte imperial, com sua peculiar burocracia, tornou-se o centro das grandes decisões, contando com os principais apoiadores e amigos do Princeps; estes compuseram o consilium e os diversos comitês no entrecruzamento do público e do privado. Igualmente, alguns focos de oposição permaneceram: os problemas nas eleições consulares entre 23 e 19 a.C. podem ser considerados indícios que a aceitação desta nova ordem das coisas ainda não era um consenso, a despeito da ênfase neste termo em Roma e ao redor do Império. Mas ao final, poucos se lembravam dos conflitos do passado, e muitos preferiram, parafraseando Tácito, a doçura do presente.

Entretanto, o grande problema para assegurar a permanência e a transmissão desta grande transformação tenazmente defendida pela obstinação de Augusto estava dentro de sua própria residência: aos infortúnios causados pelas mortes dos candidatos à sucessão constituídos pelo quase obsessivo desejo de preservação da linhagem Juliana, somou-se os interesses de membros da própria família que se viram marginalizados ou inseguros de sua preponderância neste processo.

Durante o segundo capítulo, pudemos constatar que isto não foi diferente durante o governo de Tibério, e que não o seria pelo restante da história sobre os Imperadores Júlio-Claudianos. A responsabilidade de assegurar a manutenção da corte imperial e conciliar os interesses internos em disputa dentro de sua própria residência constituíram desafios básicos que Tibério legou de seu antecessor. Seus membros, bem como o restante da aristocracia e demais indivíduos inseridos no coração deste centro decisório de poder sabiam que dele derivava a essência da soberania e da ordem neste novo sistema político.

Entre 14 e 23 d.C., observamos que o Princeps lidou perenemente com relações de força e busca por influência, favorecimento, e destaque no esquema sucessório, protagonizadas pelos núcleos familiares concentrados entre as linhagens Júlia e Cláudia. Júlia Augusta, Júlia Menor, Agripa Póstumo, Lívia Drusilla, Germânico César, Agripina Maior, Druso Cláudio e, por fim Sejano, representaram escóis (embora não desconsideremos outros que 
tangenciam as narrativas sobre a família imperial) pelos quais emanaram redes de solidariedade que precisavam ser, se possível, controlados ou coordenados por Tibério. Neste ponto residiu, sem dúvida, um dos principais aspectos do "fardo de tudo governar", a dura tarefa legada pela mente de Augusto, uma responsabilidade tão difícil quanto fora 0 estabelecimento do próprio Principado; como segundo Princeps, Tibério precisava buscar suas próprias ferramentas para manter o equilíbrio da nova e principal instituição que surgiu em meio à experimentação iniciada pelo seu predecessor.

Com a morte de Germânico e, principalmente, de Druso Cláudio, o isolamento político de Tibério se agravou. Sejano tornar-se-ia consorte na administração imperial. Pudemos observar que o Princeps tentou, a despeito tênue e instável linha existente no momento, definir qual seria o escopo de sua atuação e qual seria o do Senado, com a iniciativa de realçar o prestígio republicano desta instituição. Contudo, Tibério falhou na redistribuição da autonomia e proatividade de outrora: mais do que os interesses institucionais, eram os anseios e ambições de seus membros que determinaram a forma como eles, cada qual de uma maneira, por fim buscaram se adaptar diante da presença inequívoca de um soberano cujo favorecimento e apoio determinaram o futuro de cada um deles.

Consequentemente, status, prestígio e riqueza confirmaram-se como o foco essencial dos senadores, enquanto que a retomada de seus poderes parecia-lhes muito mais um vislumbre de caos e guerra civil do que a restauração da República. Todavia, a mera intervenção do Princeps entre os senadores - fosse para prevenir a adulação ou evitar uma punição injusta - por si só resultava em um questionamento da autonomia desta instituição. Junto a isso vieram efeitos colaterais concernentes à idiossincrasia do Principado: as ambições aristocráticas encontraram na lei de traição uma maneira eficaz de eliminar opositores no cada vez mais estreito espaço de ascensão política senatorial, e se possível garantindo a possibilidade de enriquecimento.

Em parte, e somente em parte, a causa consistiu do gradual ceticismo, ressentimento e desconfiança que teriam acometido o Princeps ao longo dos primeiros anos de seu governo. Tentamos evitar as armadilhas "psicologizantes" e há bastante tempo em desuso, por mais que a personalidade do Imperador seja atrativa pela intrínseca atratividade que a 
narrativa de Tácito ou Suetônio provoca em nós, leitores. Em verdade, as causas foram políticas, e consistiram na busca incessante por poder, no seio da família imperial, no ambiente da corte, e entre os membros da aristocracia.

O fato de não ter conseguido promover um governo apoiado na proatividade do Senado, o isolamento político no interior de sua própria residência, e a consequente frustração com a soma destes dois aspectos motivaram seu afastamento para Capri. Durante o terceiro capítulo pudemos observar que a predileção pela cultura grega e pelo ambiente ameno da Campânia justificou a escolha de Tibério por este local, mas o que o manteve lá por tanto tempo, e como agiu desde então, é justificável a partir da necessidade de restringir o acesso e a interferência daqueles que ficaram alheios à corte que neste arquipélago foi estabelecida.

Nesse sentido, o Princeps agiu como um homem de seu tempo; suas distrações e prazeres eram os mesmos de seus concidadãos, e não via incoerência ou excentricidade em suas escolhas. A peculiaridade de seu afastamento para a ilha foi posterior e, mais uma vez, política. Diferentemente dos demais romanos, o Imperador não retornou para Roma. Pelo contrário, criou um experimento político genuíno, um ponto de inflexão: transferiu o cerne do poder decisório para Capri. E de lá passou, para todos os efeitos, governar o império e controlar os vínculos com seus pares.

Entretanto, os desdobramentos de seu afastamento, embora possam ter trazido em parte a tranquilidade de uma velhice amena, sem o mise-en-scéne do cotidiano público da Cidade de Roma, apenas agravaram a anterior situação da qual provavelmente Tibério, em vão, tentara afastar-se física e geograficamente. Sua ausência de Roma permitiu a continuidade do abuso nas acusações e condenações por traição, lançou seus pares e associados na incerteza, e estabeleceu novos intermediários na rede de solidariedades por favorecimento e promoção política e social. A despeito de quais foram de fato suas esperanças quanto ao retorno de um Senado autônomo, mais consciente de seu próprio passado republicano, ou pelo menos mais bem coligado com sua visão pessoal sobre governar, e não obstante o Princeps ainda tivesse incitado o Senado a agir espontaneamente, o afastamento contribuiu ainda mais para o arrefecimento da iniciativa de seus membros. Longe de Roma, o referencial político para promover ou refrear as ações de senadores e 
equestres não estava mais visível (ou seja, sua própria pessoa), e só se comunicava mediante correspondências sujeitas à manipulação de Sejano e Macro. A soma destes fatores fez com que o debate político na capital do Império se tornasse gradualmente algo praticamente supérfluo ou perigoso.

Mais ainda, a desconfiança em relação aos interesses de seu genro, nora e netos podem ter se configurado como uma repetição do baque político sofrido em 6 a.C., quando possivelmente as imprecações de Júlia Augusta o impeliram ao isolamento; a postura de Agripina, o eventual apoio de seus associados, e o incremento da atmosfera de desconfiança e ressentimento pelas mãos de Sejano (com a manutenção deste legado com Macro) forneceram mais argumentos para manter o seu afastamento. Se a morte de Druso fizera do possível desejo de abdicação política um sonho distante ${ }^{903}$ (e o meio-termo deste sonho configurara-se com o afastamento), Tibério não conseguiu se desvencilhar do posto que the assegurou a própria permanência - ou sobrevivência - durante vinte e três anos de governo. Pelo fato de o Principado estar apenas no início de seus mais de dois séculos de história, Tibério talvez não tivera a percepção de que nenhum soberano conseguiria se desvencilhar do seu posto, ou mesmo de escapar com vida da posição de Imperador.

Nos últimos anos de seu governo, pudemos observar que, conforme fora durante todo o período em que se fizera presente na capital do Império, as linhas gerais de sua administração permaneceram basicamente as mesmas. $O$ distanciamento de Roma não perturbara a estabilidade da Itália e das demais províncias. Esta constatação, essencialmente o fato de que a ordem romana não dependia de um Imperador centrado em Roma, e de que o centro do poder estaria onde estivesse o Princeps e sua corte, seria algo natural de Adriano em diante.

Contudo, para os contemporâneos de um período em que o Principado começava sua consolidação, a repercussão do afastamento de Tibério deve ter sido no mínimo significativa. Alheio ou mesmo avesso à opinião outra que não fosse da de seus próprios pares - e mesmo essa última, na medida em que sua morte se aproximava, já nem parecia tão relevante - a impopularidade foi a

${ }^{903}$ LEVICK, 1999, p. 178-80; SEAGER, 2005, p. 209-10. 
principal mácula que caracterizou sua posteridade; esta qualificação perenizouse na tradição aristocrática porquanto viera acompanhada da provável obliteração pelo restante da população. Nos últimos momentos de sua vida e governo, Tibério sabia que os olhares já se direcionavam para Gaio César; e a essa mesma tradição não tardou a percepção de que a existência de um "mau imperador" seria uma condição com a qual os sujeitos próximos do poder teriam de lidar pelo restante da história do mundo romano. Esperamos que nossas considerações continuem servindo de estímulo para o estudo desta tradição, e para a existência de uma infinidade de questões e possibilidades que permitem sempre uma nova interpretação do Principado, especialmente durante o período que nestas páginas abordamos. 


\section{REFERÊNCIAS}

\section{A) Documentação}

CÍCERO. Epistulae ad Familiares: Volume 1, 62-47 B.C. Org. D.R. ShackletonBailey. Cambridge: Cambridge University Press, 2004.

DION CÁSSIO. Roman History: The reign of Augustus (Books 50-56). Tradução de lan Scott-Kilvert, com introdução de John Carter. London: Penguin Classics, 1987.

Roman History 56-70. LOEB Classical Library. Traduzido por

Earnest Cary. Vol. 7. London: Cambridge University Press, 1924.

ESTRABÃO. Geography (Books 3-5). LOEB Classical Library. Traduzido por Horace Leonard Jones. London: Cambridge University Press, 1923.

EHRENBERG, Victor; JONES, A.H.M. Documents illustrating the reigns of Augustus \& Tiberius. Oxford: Clarendon Press, 1949.

FLÁVIO JOSEFO. Jewish Antiquities (Books 18-19). LOEB Classical Library.

Traduzido por Louis. H. Feldman. London: Cambridge University Press, 1965.

PLíNIO O VELHO. Natural History. LOEB Classical History. Traduzido por H. Rackman. London: Cambridge University Press, 1940.

RES GESTAE DIVI AUGUSTI. Tradução, introdução e comentários de P.A. Brunt e J.M. Moore. Oxford: Oxford University Press, 1983. . Tradução de Sarolta A. Takács. In: ECK, Werner. The Age of Augustus. London: Routledge, 2007. pp. 172-190.

SÊNECA. Dialogues and Essays. Traduzido por John Davie. Oxford: Oxford University Press, 2009.

SUETÔNIO. Lives of the Caesars. LOEB Classical Library. Traduzido por C.J. Rolfe. Vol. 1 e 2. London: Cambridge University Press, 1928.

SUTHERLAND, C.H.V. Roman Imperial Coinage. Volume I, revisado. London: Spink and Son Ltd, 1984.

TÁCITO. The Annals. LOEB Classical Library. Traduzido por John Jackson. London: Cambridge University Press, 1923. 
. The Annals. Traduzido por A.J. Woodman. London:

Hackett, 2004.

VELÉIO PATÉRCULO. Compendium of Roman History. LOEB Classical Library. Traduzido por Frederick W. Shipley. London: Cambridge University Press, 1924.

\section{B) Obras gerais}

ADCOCK, F.E. Las ideas y la practica politica en Roma. Tradução de F. Rubio Llorente. Caracas: Universidad Central de Venezuela, 1989.

ANDO, Clifford. Imperial Ideology and Provincial Loyalty in the Roman Empire. Los Angeles: University of California Press, 2000.

ALFOLDY, Geza. História Social de Roma. Lisboa: Editorial Presença, 1989.

ALSTON, Richard. Aspects of Roman History AD $14-117$. London: Routledge, 1998.

BAUMAN, Richard. Women and politics in Ancient Rome. London: Routledge, 1994.

Impietas in principem. Munchen: C.H. Beck'sche

Verlasbuchhandlung, 1974.

BEARD, M; CRAWFORD, M. Rome in the Late Republic. London: Duckworth, 1985.

BÉRANGER, Jean. Recherches sur l'aspect idéologique du Principat. Basel: Verlag Friedrich Reinhardt, 1953.

BENARIO, Herbert W. "Tacitus and the Principate." The Classical Journal, Vol. 59. Northfield: 1964, pp. 97-106.

.The end of Salustius Crispus". The Classical Journal, Vol. 57, No.

7. Northfield: 1962, pp. 321-322.

BERGER, Adolf. Encyclopedic Dictionary of Roman Law. Philadelphia: The American Philosophical Society, 1953.

$\mathrm{BIRCH}$, R.A. "The correspondence of Augustus: some notes on Suetonius, Tiberius 21. 4-7." The Classical Quarterly, New Series, Vol. 31, No.1 de 1981: 155-161.

BOND, Shelagh. "The coinage of the Early Roman Empire". Greece \& Rome, Second Series, Vol. 4, No. 2. London: 1957, pp. 149-159. 
BONNEFOND-COUDRY, Marianne. "Princeps et Sénat sous les Julioclaudiens: des relations à inventer". Mélanges de l'Ecole française de Rome: Antiquité, 107, №1. Roma: 1995, pp. 225-254.

BINGHAM, Sandra. The praetorian guard in the political and social life of JulioClaudian Rome. Columbia: University of British Columbia, 1997.

BRAUND, David C. Augustus to Nero: a sourcebook on Roman History 31 BC $A D$ 68. London: Croom Helm, 1985.

BRUNT, Peter. "The Role of the Senate in Augustan Regime". The Classical Quarterly - New Series, Vol. 34, № 2. London: 1984, pp. 423-444.

. "The Lex Valeria Cornelia". The Journal of Roman Studies, Vol. 51. London: 1961, pp. 71-83.

CASINOS MORA, Francisco Javier. La noción romana de auctoritas y la responsabilid

por auctoritas. Madrid: Editorial Comares, 2000.

CÀSSOLA, Filippo. "La conquista romana. La regione fino al $V$ secolo d.C.". In: CARRATELLI, Giovanni C. (org). L'Evo antico. Napoli: Electa Napoli, 1991. pp. 103-151.

CHARLESWORTH, M.P. "Tiberius and the death of Augustus". The American Journal of Philology, Vol. 44, No. 2. Baltimore: 1923, pp. 145-157.

CHASTAGNOL, André. Le Sénat Romain à l'époque impériale: recherches sur la composition de l'Assemblée et le statut de ses membres. Paris: Les Belles Letres, 1992.

CHILTON, C.W. "The Roman Law of Treason under the Early Principate". The Journal of Roman Studies, Vol. 45. London: 1955, pp. 73-81.

CIZEK, Eugene. "Les problèmes du Principat et l'élection des magistrats chez Velleius Paterculus". Revue de philologie, littérature et d'histoire anciennes, Vol. 77. Paris: 2003, pp. 23-36.

CORBIER, Mireille. "Le Maison des Césars". In: Épouser au plus proche: inceste, prohibitions et stratégies matrimoniales autour de la Mediterranée. Paris: Éditions de L’École des Hautes Études en Sciences Sociales, 1994. pp. 243-291.

. "La famille de Séjan à Volsinii: la dédicace des Seii, curatores Aquae". Mélanges de l'Ecole française de Rome - Antiquité Tardive. 95, №2. Roma: 1983, pp. 719-756. 
CROOK, J.A. "Political History, 30 B.C to 14 A.D". In: BOWMAN, A.K.; CHAMPLIN, E.; LINTOTT, A. (org.). The Cambridge Ancient History - Second Edition. Cambridge: Cambridge University Press, 2008. pp. 70-112. . "Augustus: power, authority, achievement". In: BOWMAN, A.K.; CHAMPLIN, E.; LINTOTT, A. (org.). The Cambridge Ancient History - Second Edition. Cambridge: Cambridge University Press, 2008. pp. 103-146. . Consilium Principis: imperial councils and counselors from Augustus to Diocletian. Cambridge: Cambridge University Press, 1955.

D'AMATO, Rafaelle; RAVA, Giuseppe. Roman Centurions 753-31 BC: The Kingdom and the Age of the Consuls. Oxford: Osprey Publishing, 2011.

D'ARMS, John. Romans on the Bay of Naples. Harvard: Harvard University Press, 1970.

DETWEILER, Robert. "Historical perspectives on the death of Agrippa Postumus". The Classical Journal, Volume 65, No. 7. Northfield: 1970, pp. 289295.

DUPRAZ, Louis. "Les avenues militaires de l'association de Tibère au principat". In: De l'association de Tibère au principat a la naissance du Christ. Fribourg: Editions Universitaires Fribourg/Souisse, 1966. pp. 1-99.

ECK, Werner. The Age of Augustus. London: Routledge, 2007.

EDER, Walter. "Augustus and the Power of Tradition". In: The Cambridge Companion to the Age of Augustus. Cambridge: Cambridge University Press, 2007. pp.13-32.

EHRENBERG, Victor. "Some Concepts of State and Empire". In: Man, State and Deity. London: Methuen \& Co Ltd., 1984. Pp. 107-126.

FEDERICO, Eduardo. "Capri dall'espansione cumana nel Golfo (VII a.C.) al foedus Neapolitanum". In: FEDERICO, E; MIRANDA, E. Capri Antica - dalla preistoria alla fine dell'età romana. Capri: Edizioni la Conchiglia, 1999. pp. 375416.

FERRARI, Jean-Louis. "Les origines de la loi de majesté à Rome". Comptesrendus des séances de l'Académie des Inscriptions et Belles-Lettres, Vol. 127, No. 4. Paris: 1983. pp. 556-572.

FHANTHAM, Elaine. Julia Augusti - The Emperor's Daughter. London: Routledge, 2006. 
FRANK, Tenney. "The Financial Crisis of 33 A. D". The American Journal of Philology, Vol. 56, No. 4. Baltimore, 1935, pp. 336-341

FRITZ, Kurt Von. "Tacitus, Agricola, Domitian, and the Problem of the Principate". Classical Philology, Vol.52, n². Chicago: 1957, pp. 73-97.

GALINSKY, Karl. "Introduction". In: The Cambridge Companion to the Age of Augustus. Cambridge: Cambridge University Press, 2007. pp. 1-12.

Augustan Culture: an interpretative introduction. Princeton: Princeton University Press, 1996.

GALVÃO, Carlos. "Autocracia, ressentimento e engajamento político no Principado Romano". In: Memória e (res) sentimento: indagações sobre uma questão sensível. Campinas: Unicamp, 2004. pp. 320-342.

GARNSEY, P; SALLER, R. The Roman Empire: Economy, Society and Culture. London: Duckworth, 1987.

GONÇALVES, Ana Teresa Marques. "Ação política e propaganda dentro das fronteiras do Império Romano". In: Anais do XX simpósio nacional de História. São Paulo: FFLCH/Humanitas, 1999, vol. 1, pp. 517-527.

GONZALEZ, Julian. "Tacitus, Germanicus, Piso and the Tabula Siarensis". The American Journal of Philology, Vol. 120, No. 1. Baltimore: 1999, pp. 123-142.

GRADEL, Ittai. Emperor Worship and Roman Religion. Oxford: Clarendon Press, 2002.

GRANT, Michael. From Imperium to Auctoritas. Cambridge: Cambridge University Press, 1969.

. "The Augustan Constitution". Greece and Rome, Vol. 18, №

54. London: 1949, pp. 97-112.

GRIMAL, Pierre. O século de Augusto. Lisboa: Editorial Presença, 1992.

GRUEN, Eric. "Augustus and the making of the Principate". In: In: The Cambridge Companion to the Age of Augustus. Cambridge: Cambridge University Press, 2007. pp.33-54.

GUARINELO, Norberto L; JOLY, Fábio D. "Ética e ambigüidade no Principado de Nero". In: Ética e política no Mundo Antigo. Campinas: Unicamp, 2001. Pp.133-151.

HAMMOND, Mason. The Augustan Principate. New York: Russel \& Russel, 1961. 
. "Res olim dissociabiles: Principatus ac libertas: liberty under the Roman Empire". Harvard studies in classical philology, Vol. 67. Harvard: 1963, pp. 93-113.

HOPKINS, Keith. BURTON, Graham. "Ambition and withdrawal: the senatorial aristocracy under the emperors". In: Sociological studies in Roman History. London, Cambridge University Press, 1983. p. 120-199.

HOUSTON, George W. "Tiberius on Capri". Greece and Rome, Vol. 32, No. 2. London: 1985, pp. 179-196.

JOLY, Fábio Duarte. Tácito e a metáfora da escravidão. São Paulo: Edusp, 2004.

JONES, A.H.M. "The Imperium of Augustus". The Journal of Roman Studies, Vol. 41. London: 1951, pp. 112-119.

KAMPFF, G. "Three Senate Meetings in the Early Principate". Phoenix, Vol. 17, No. 1. Toronto: 1963, pp. 25-58.

KEHOE, Dennis. "Tacitus and Salustius Crispus". The Classical Journal, Vol. 80, No. 3. Northfield: 1985, pp. 247-254.

KEPPIE, Lawrence. "Capri". In: The romans on the bay of Naples: an archaeological guide. Stroud: New History Press, 2009. pp. 160-166.

KRAUS, C.S; A.J. WOODMAN. "Tacitus". In: Latin Historians. London: Oxford University Press, 1977. pp. 88-127.

KRAUSE, Clemens. Villa Jovis: L'Edificio Residenziale. Nápoles: Electa Napoli, 2005.

. "L'edifizio residenziale di Villa Jovis". In: FEDERICO, E;

MIRANDA, E. Capri Antica - dalla preistoria alla fine dell'età romana. Capri: Edizioni la Conchiglia, 1999. pp. 225-240.

LACEY, W.K. "Nominatio and elections under Tiberius". Historia: Zeitschrift für Alte Geschichte, Vol. 12, No. 2. Erfurt: 1963, pp. 167-176. . "Octavian in the Senate, January 27 B.C.". The Journal of Roman Studies, Vol. 64. London: 1974, pp. 176-184.

LAWRENCE, Ray. "Rumour and Communication in Roman Politics". Greece \& Rome, Vol. 41, № 1. London: 1994, pp. 62-74.

LENDON, J.E. Empire of Honour: The art of government in the Roman World. Oxford: Oxford University Press, 2005. 
LEVICK, Barbara. "Abdication and Agrippa Postumus" Historia: Zeitschrift für Alte Geschichte, Vol. 21, No. 4. Erfurt: 1972, pp.674-697.

- "Imperial Control of the Elections under the Early

Principate: Commendatio, Suffragatio, and Nominatio". Historia: Zeitschrift für Alte Geschichte, Vol. 16, No. 2. Erfurt: 1967, pp. 207-230.

. Tiberius the Politician. London: Routledge, 1999.

. "Julians and Claudians". Greece \& Rome - Second Series,

Vol. 22, No. 1. London: 1975, pp. 29-38.

LINTOTT, Andrew. "What Was the 'Imperium Romanum?". Greece \& Rome, Vol. 28, No. 1. London: 1981, pp. 53-67.

LOBUR, John Alexander. Consensus, Concordia, and the Formation of Roman Imperial Ideology. London: Routledge, 2008.

MACMULLEN, Ramsay. Roman Social Relations: 50 B.C to A.D. 284. New Haven: Yale University Press, 1974.

MALLOCH, S.J.V. "The end of the Rhine mutiny in Tacitus, Suetonius and Dio". The Classical Quarterly, New Series. Vol. 54, No. 1. London: 2004, pp. 198210.

MAIURI, Amedeo. Capri: Histoire et Monuments. Roma: Instituto Poligrafico dello Stato, 1956.

MANNING, C. E. "Liberalitas - the decline and rehabilitation of a virtue". In: Greece \& Rome, Vol. 32, No. 1. London: 1985, pp. 73-83.

MARSH, Frank Burr. "Roman Parties in the Reign of Tiberius". The American Historical Review, Vol. 31, № 2. Bloomington: 1926, pp. 233-250.

. The reign of Tiberius. Oxford: Oxford University Press, 1931.

MILES, Richard. "Communicating Culture, Identity and Power". In: HUSKINSON, Janet (org.). Experiencing Rome: Culture, Identity and Power in the Roman Empire. London: Routledge, 2000. pp. 29-56.

MILLAR, Fergus. "Two Augustan Notes". The Classical Review, Vol. 18, No. 3. Cambridge: 1968, pp. 263-266.

"The first revolution: Imperator Caesar, 36-28 BC". In: La

Revolution Romaine après Ronald Syme. Gèneve: Fondation Hardt, 2000. pp. 1-38. 
. "The Emperor at work: imperial functions and their social settings". In: The Emperor in the Roman World. London: Duckworth Publishing, 2001. pp. 203-274.

MILLER, N.P. "Tiberius speaks: An Examination of the Utterances Ascribed to Him in the Annals of Tacitus". The American journal of philology, Vol. 89, No.1. Baltimore: 1968, pp. 1-19.

MOMMSEN, Theodor. "Tiberius". In: A History of Rome under the emperors. London: Routledge, 1992. pp. 113-132.

MOMMIGLIANO, Arnaldo. Raízes Clássicas da Historiografia Moderna. Bauru: EDUSC, 2004.

MOURITSEN, Henrik. Plebs and Politics in the Late Roman Republic. Cambridge: Cambridge University Press, 2004.

NICHOLS, John. "Antonia and Sejanus". Historia: Zeitschrift für Alte Geschichte, Vol. 24, No. 1. Erfurt: 1975, pp. 48-58.

NICOLET, Claude. "Libertas: le citoyen et les pouvoirs". In: Le métier de citoyen dans

la Rome republicaine. Paris: Gallimard, 1976. pp. 425-444. . "Augustus, Government and the Propertied Classes". In:

MILLAR, F; SEGALL, E. Caesar Augustus: Seven Aspects. Oxford: Clarendon Press, 2011. pp. 89-128.

NOREÑA, Carlos F. The communication of the emperor's virtues. The Journal of Roman Studies, Vol. 91. London: 2001, pp. 146-168.

OBER, Josiah. "Tiberius and the Political Testament of Augustus". Historia: Zeitschrift für Alte Geschichte, Vol. 31, No. 3. Erfurt: 1982, pp. 306-328.

PAPPANO, Albert E. "Agrippa Postumus". Classical Philology, Vol. 36, № 1. London: 1941, pp. 30-45.

PEACHIN, Michael. "Rome the Superpower: 96-235 CE". In: POTTER, David (org). A Companion to the Roman Empire. Oxford: Blackwell Publishing, 2006. Pp. 126-152.

PERCIVAL, John. "Tacitus and the Principate". Greece \& Rome, Vol.27, No.2. London: 1980, pp.119-133.

PIPPIDI, D.M. Autour de Tibère. Bucuresti: Institutul de Istorie Universala N. lorga, 1944. 
POLLARD, Nigel. "The Roman Army". In: POTTER, David (org). A Companion to the Roman Empire. Oxford: Blackwell Publishing, 2006. Pp. 206-226.

POTTER, David. "The Tabula Siarensis, Tiberius, the Senate, and the Eastern Boundary of the Roman Empire". Zeitschrift für Papyrologie und Epigraphik, Vol. 69. Bonn: 1987, pp. 269-276.

RICHARDSON, J.S. "Imperium Romanum: Empire and the Language of Power. The Journal of Roman Studies, Vol. 81. London: 1991, pp. 1-9.

RODEWALD, Cosmo. Money in the Age of Tiberius. Manchester: Manchester University Press, 1976.

ROGERS, Robert Samuel. "Tiberius' reversal of an augustan policy". Transactions and Proceedings of the American Philological Association, Vol. 71. Baltimore: 1940, pp. 532-536. . "Tiberius' Travels, A.D. 26-37". The Classical Weekly, Vol. 39, № 6. New York, 1945, pp. 42-4.

ROSTOVTZEFF, Michael I. The Social and Economic History of the Roman Empire. Second Edition. Oxford: The Clarendon Press, 1957.

ROULAND, Norbert. Pouvoir politique et dépendance personelle dans l'Antiquité romaine. Bruxelas: Latomus Révue d'Études latines, 1971.

ROWE, Greg. "The emergence of Monarchy: 44 BCE - 96 CE". In: POTTER, David (org). A Companion to the Roman Empire. Oxford: Blackwell Publishing, 2006. Pp. 114-123.

. Princes and Political Cultures: The New Tiberian Senatorial Decrees. Michigan: University of Michigan Press, 2002.

RUTLEDGE, Steven H. "Tiberius' Philhellenism". The Classical World, Vol. 101, No 4. New York, 2008, pp. 453-467.

SAVINO, Eliodoro. "Capri dal foedus Neapolitanum (326 a.C.) ao VI secolo d.C.". In: FEDERICO, E; MIRANDA, E. Capri Antica - dalla preistoria alla fine dell'età romana. Capri: Edizioni la Conchiglia, 1999. pp. 375-416.

SCOTT, Kenneth. "Tiberius' refusal of the title Augustus". Classical Philology, Vol. 27, No. 1. London: 1932, pp. 43-50.

SCULLARD, M.M. From Grachii to Nero: A History of Rome from $133 \mathrm{BC}$ to $A D$ 68. London: Routledge, 2011.

SEAGER, Robin. Tiberius. London: Routledge, 2004. 
SALLER, Richard P. Personal patronage under the Early empire. Cambridge: Cambridge University Press, 1982.

SOUTHERN, Pat. Augustus. London: Routledge, 1998.

SHOTTER, David. "Elections under Tiberius". The Classical Quarterly, New Series, Vol. 16, No. 2. London: 1966, pp. 321-332.

. Tiberius Caesar. London: Routledge, 2004.

"Tiberius and Asinius Gallus". Historia: Zeitschrift für Alte Geschichte, Vol. 20, No. 4. Erfurt, 1971, pp. 443-457.

SMITH, Rowland. "The Construction of the Past in the Roman Empire". In: POTTER, David (org). A Companion to the Roman Empire. Oxford: Blackwell Publishing, 2006. Pp. 411-438.

STE. CROIX, G.E.M de. The Class Struggle in the Ancient Greek World: From the Archaic Age to the Arab Conquests. New York: Cornell University Press, 1989.

STEWART, A.F. "To Entertain an Emperor: Sperlonga, Laokoon and Tiberius at the Dinner-Table". The Journal of Roman Studies, Vol. 67. London: 1977, pp. 76-90.

STEVENSON, T.R. "The Ideal Benefactor and the Father Analogy in Greek and Roman Thought". The Classical Quarterly, vol.42, n². London: 1992, p.421436.

SUMI, Geoffrey S. Ceremony and Power: Performing Politics in Rome between Republic and Empire. Ann Arbor: Michigan University Press, 2005.

SUMNER, G.V. "The family connections of L. Aelius Seianus". Phoenix, Vol.19, No. 2, Toronto: 1965, pp. 134-145.

SUTHERLAND, C.H.V. "Two virtues of Tiberius: a numismatic contribution to the history of his reign. The Journal of Roman Studies, Vol. 28, part 2. London: 1938, pp. 129-40.

SYME, Ronald. The Roman Revolution. Oxford: Clarendon Press, 1939. . "Mendacity in Velleius". The American Journal of Philology, Vol.

99, No. 1. Baltimore, 1978, pp. 45-63.

. Tacitus. Oxford: Clarendon Press, 1958.

. "Sejanus on Aventine". Hermes, Vol. 84, No. 3. Stuttgart: 1956,

pp. 257-266. 
TAYLOR, Lily Ross. "Tiberius' refusal of divine honours". Transactions and Proceedings of the American Philological Association, Vol. 60. Baltimore: 1929, pp. 87-101.

TALBERT, Richard. J.A. "The Emperor in the Senate". In: The Senate of Imperial Rome. New Jersey: Princeton University Press, 1984. pp. 163-184.

"Augustus and the Senate". Greece \& Rome, Second Series, Vol. 31. London: 1984, pp. 55-63.

TURCAN, Robert. Vivre a la cour des Césars - d'Auguste à Dioclétien. Paris: Les Belles Letres, 1987.

WALLACE-HADRILL, Andrew. "Mutatio Morum: the idea of a Cultural revolution". In: HABINEK, T (org.). The Roman Cultural Revolution. Cambridge: Cambridge University Press, 1997. pp. 3-22.

. "The imperial court". In: BOWMAN, A.K.; CHAMPLIN, E.;

LINTOTT, A. (org.). The Cambridge Ancient History - Second Edition. Cambridge: Cambridge University Press, 2008. pp. 283-308. . "Civilis Princeps: Between citizen and king". The Journal of Roman Studies, Vol. 72. London: 1982, pp. 32-48.

WELLESLEY, K. "The dies imperii of Tiberius". The Journal of Roman Studies, Vol. 57, No. 1. London: 1967, pp. 23-30. . "Can You Trust Tacitus?". Greece \& Rome, Second Series, Vol.1, No. 1. London: 1954, p.13-33.

WIEDEMANN, T.J.E. "Tiberius to Nero" In: BOWMAN, A.K.; CHAMPLIN, E.; LINTOTT, A. (org.). The Cambridge Ancient History - Second Edition. Cambridge: Cambridge University Press, 2008. pp.

WINTERLING, Aloys Politics and Society in Imperial Rome. Oxford: WileyBlackwell, 2010.

WIRSZUBSKI, Chaim. Libertas as a political idea during the late Republic and early

Principate. London: Cambridge University Press, 1968.

WISEMAN, T.P. New Man in the Roman Senate (139 B.C. - A.D. 14). Oxford: Oxford University Press, 1971.

VEYNE, Paul. "L'Empereur, ses concitoyens et ses sujets". In: Idéologies et valeurs civiques dans le monde Romain. Paris: Picard, 2002. pp. 44-79.

YAVETZ, ZVI. Plebs and Princeps. London: Duckworth, 1969. 
Tiberio dalla finzione alla pazzia. Bari: Edipuglia, 1999. 
ANEXOS 


\section{Anexo 01}

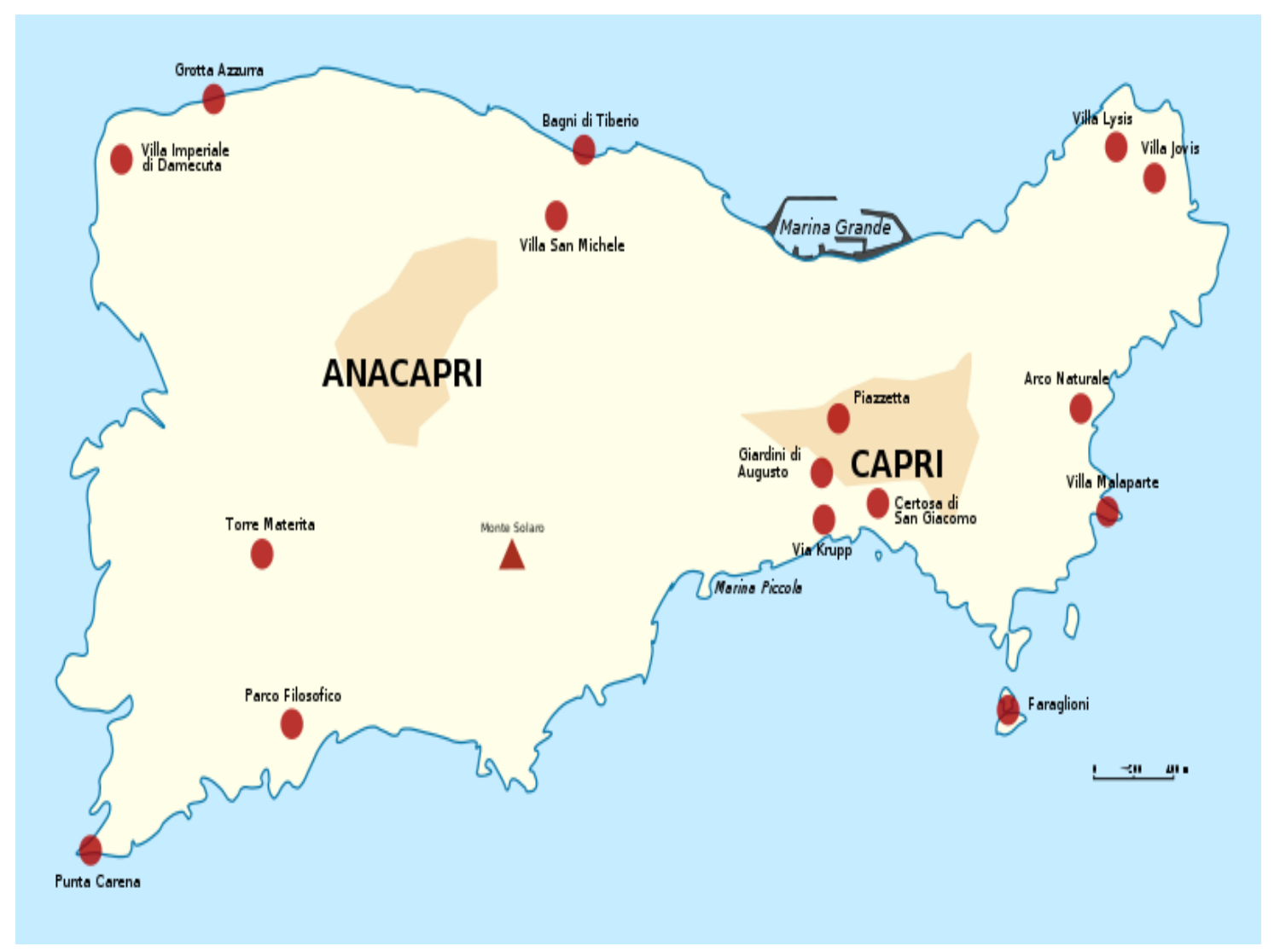

Mapa atual de Capri com os principais sítios arqueológicos. Extraído de http://commons.wikimedia.org/wiki/File:Capri sights.svg, em 08 de julho de 2013. 
Anexo 02

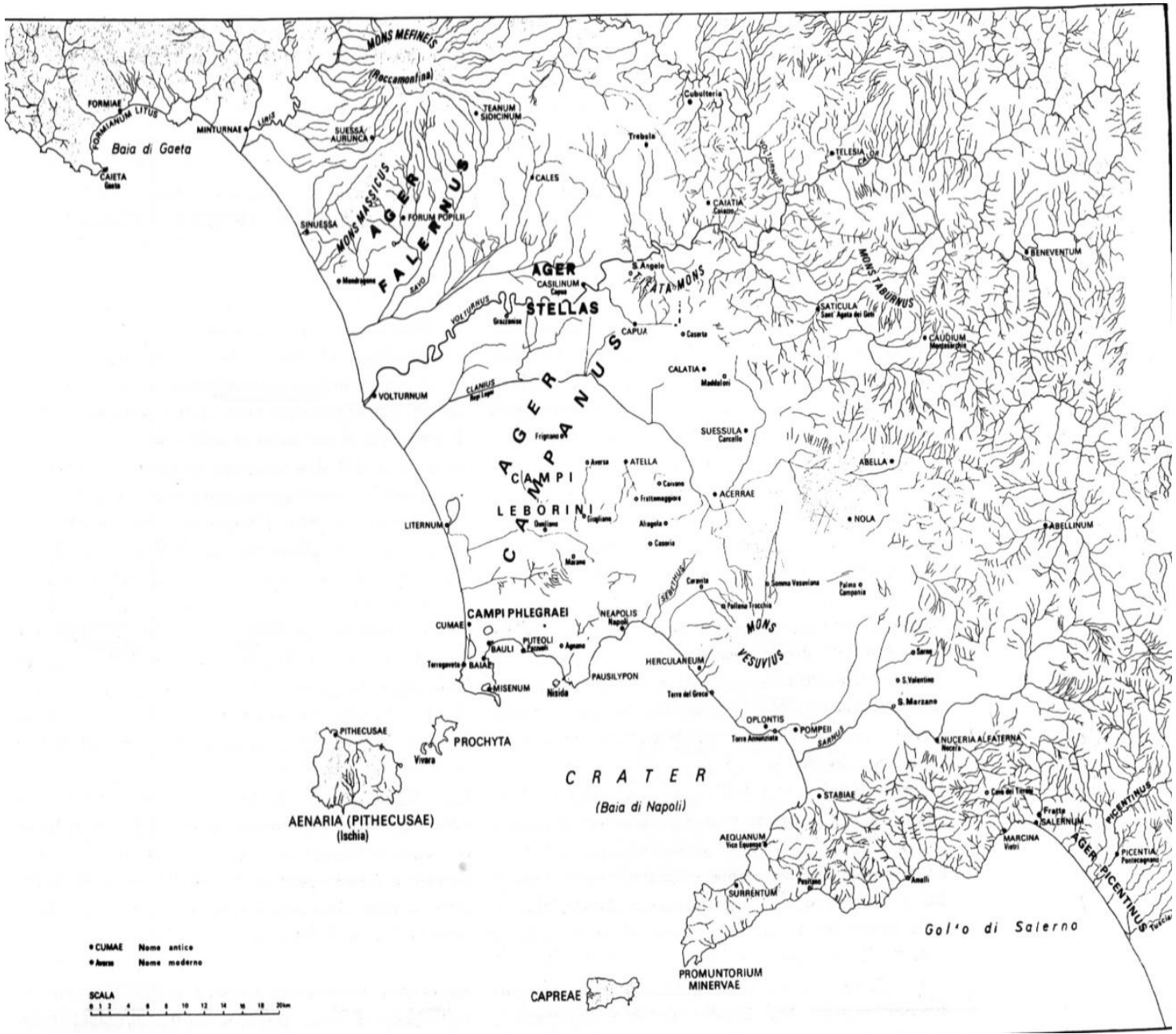

Mapa da Campânia Antiga, por Frederiksen (1984) apud BALDACCI, 1991, p.

23. 
Anexo 03

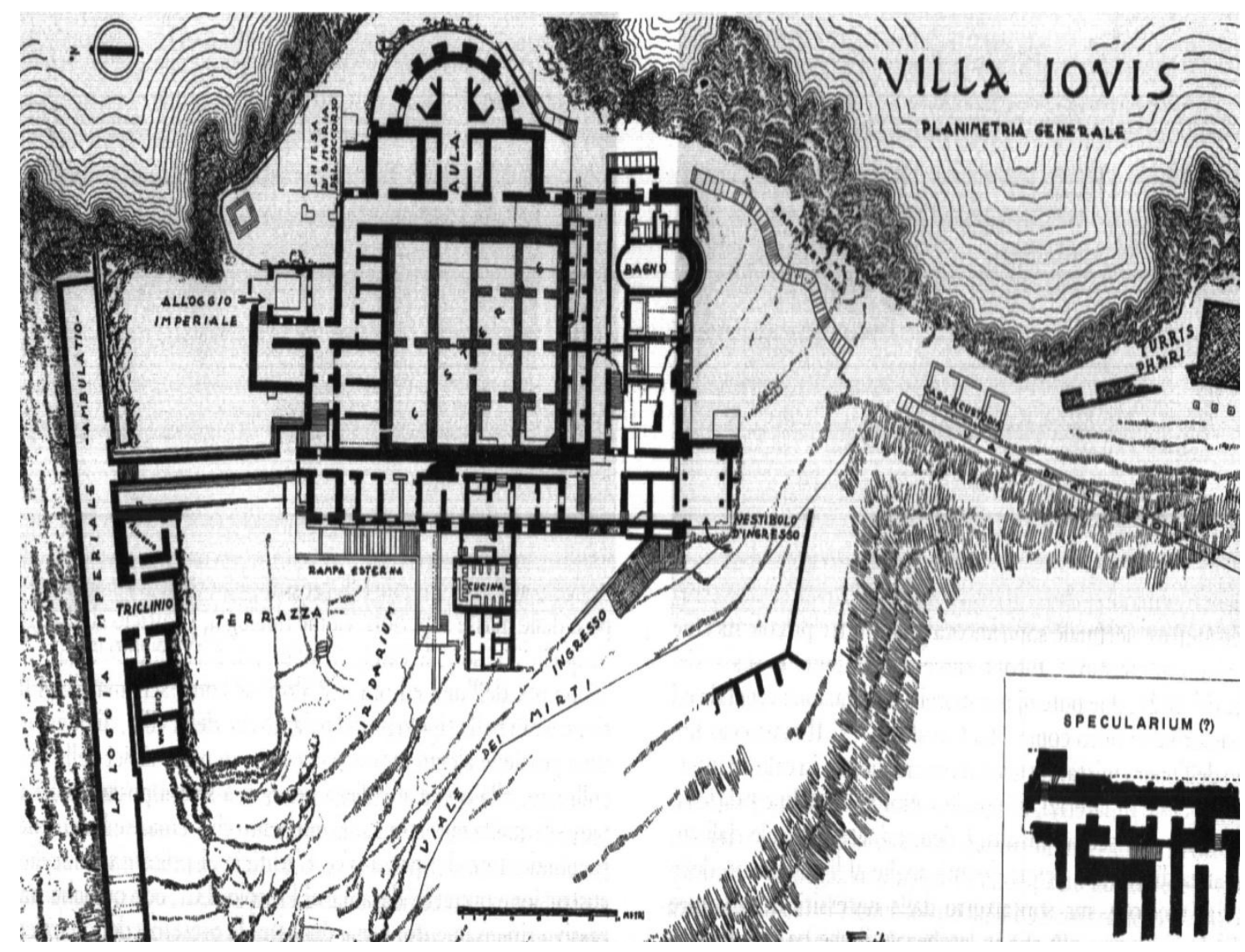

Reconstituição da planta da "Villa Jovis" por A. Maiuri apud BELLI et al, 1998, p. 186. 
Anexo 04.

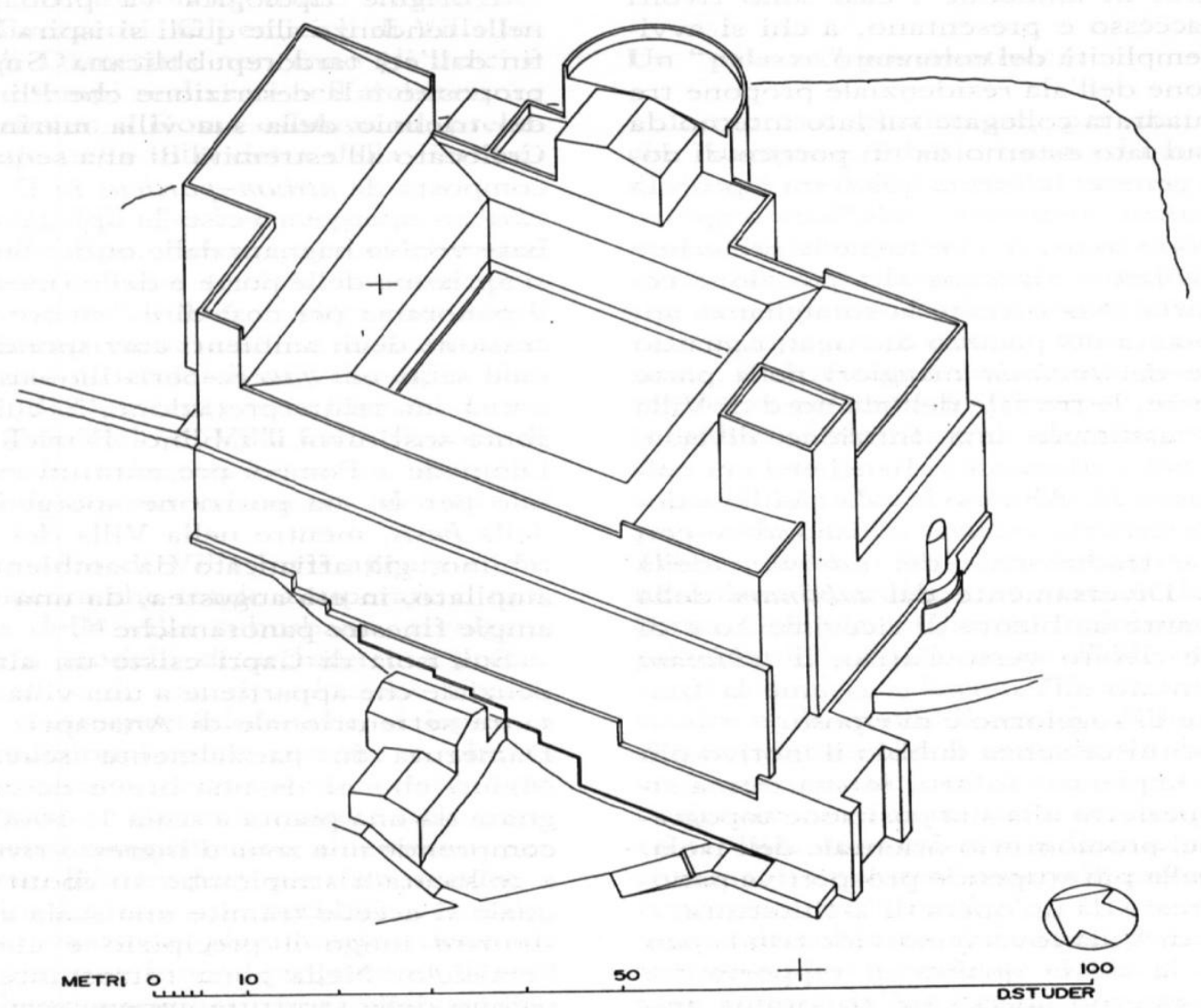

Reconstituição isométrica da Villa Jovis. KRAUSE, 1998, p. 235. 